SUPPLEMENTARY INFORMATION

\title{
Chemical composition and synergistic antimicrobial effects of a vegetatively propagated Cameroonian lemon, Citrus $x$ limon (L.) Osbeck
}

Mohamed Foundikou Nsangou ${ }^{\mathrm{a}}$, Emmanuel Ngeufa Happi ${ }^{\mathrm{a}}$, Simone Véronique Fannang ${ }^{\mathrm{b}}$, Albert Fouda Atangana ${ }^{c}$, Alain François Kamdem Waffo ${ }^{a *}$, Jean Duplex Wansi ${ }^{a}$, Sani M. Isyaka $^{\mathrm{d}}$, Nicholas Sadgrove ${ }^{\mathrm{e}}$, Nobert Sewald ${ }^{\mathrm{f}}$, Moses K. Langat ${ }^{\mathrm{e}}$,

${ }^{a}$ Chemistry Laboratory, University of Douala, Faculty of Sciences, 24157 Douala, Cameroon

${ }^{b}$ Department of Pharmacy, University of Douala, Faculty of Medicine and Pharmaceutical Sciences, 2701 Douala, Cameroon

${ }^{c}$ Department of Chemistry, University of Maroua, Faculty of Sciences, 814 Maroua, Cameroon ${ }^{d}$ Department of Chemistry, FEPS, University of Surrey, Guildford, Surrey, GU2 7XH UK

e Jodrell Laboratory, Natural Capital and Plant Health Department, Royal Botanic Gardens, Kew, Richmond, Surrey, TW9 3DS, UK

fOrganic and Bioorganic Chemistry, Faculty of Chemistry, Bielefeld University, D-33501 Bielefeld, Germany

*Corresponding authors:

Moses K Langat,

Jodrell Laboratory, Natural Capital and Plant Health Department, Royal Botanic Gardens, Kew, Richmond, Surrey, TW9 3DS, United Kingdom

E-mail address: m.langat@kew.org

and

Alain François Kamdem Waffo

Chemistry Laboratory, University of Douala, Faculty of Sciences, 24157 Douala, Cameroon E-mail address: akamdemfr@yahoo.fr 


\section{SUPPLEMENTARY MATERIAL}

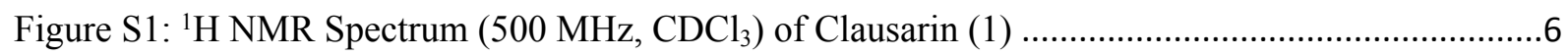

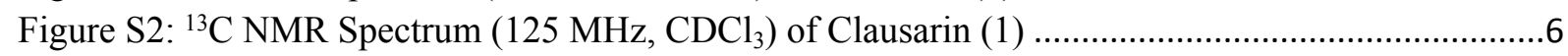

Figure S3: 135-DEPT $\left(125 \mathrm{MHz}, \mathrm{CDCl}_{3}\right)$ Spectrum of Clausarin (1) .................................................

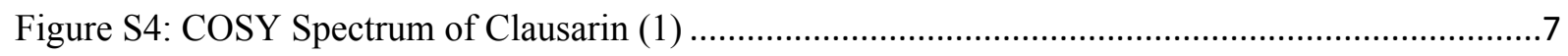

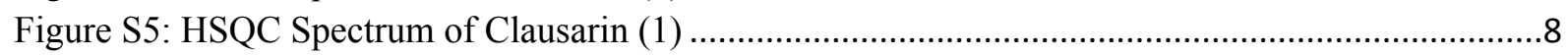

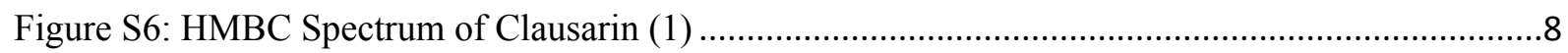

Figure S7: ${ }^{1} \mathrm{H}$ NMR Spectrum $\left(500 \mathrm{MHz}, \mathrm{CDCl}_{3}\right.$ ) of Xanthyletin (2) .............................................

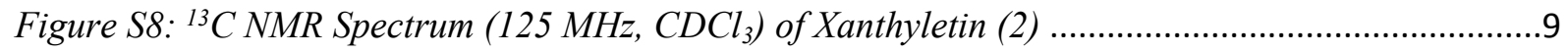

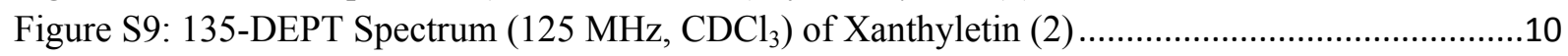

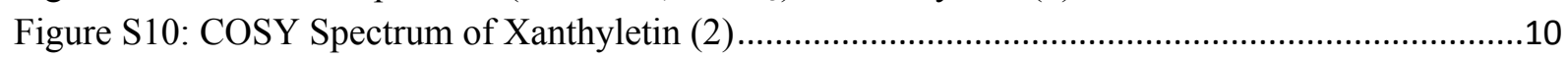

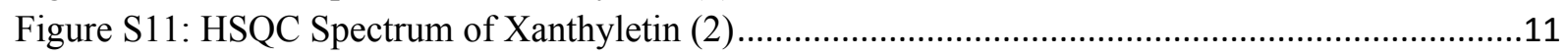

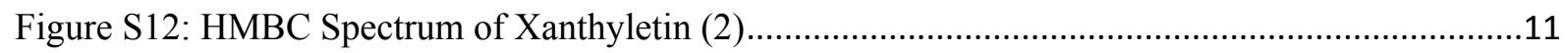

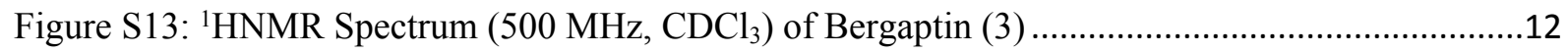

Figure S14: 135-DEPT Spectrum (125 MHz, $\mathrm{CDCl}_{3}$ ) of Bergaptin (3) ...........................................12

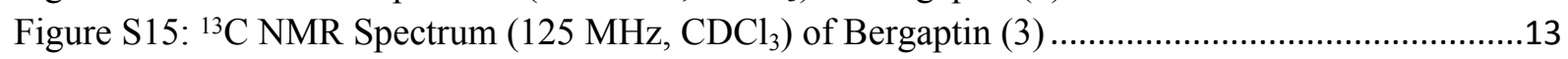

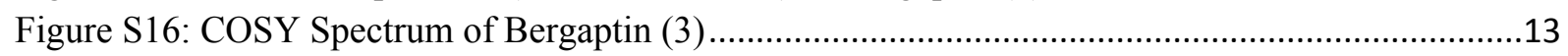

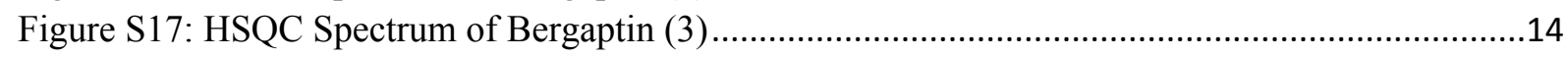

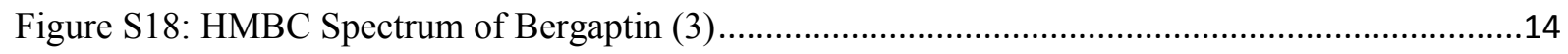

Figure S19: ${ }^{1} \mathrm{H}$ NMR Spectrum $\left(500 \mathrm{MHz}, \mathrm{CDCl}_{3}\right.$ ) of Suberosin (4) .............................................15

Figure S20: ${ }^{13} \mathrm{C}$ NMR Spectrum $\left(125 \mathrm{MHz}, \mathrm{CDCl}_{3}\right.$ ) of Suberosin (4) ............................................15

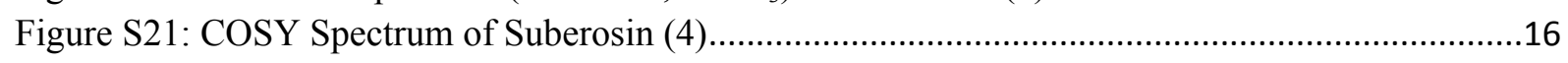

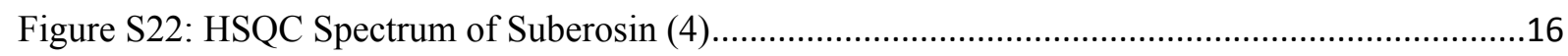

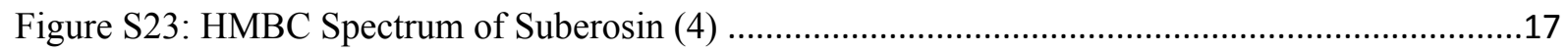

Figure S24: ${ }^{1} \mathrm{H}$ NMR Spectrum $\left(500 \mathrm{MHz}, \mathrm{CDCl}_{3}\right.$ ) of E-suberenol (5)..........................................17

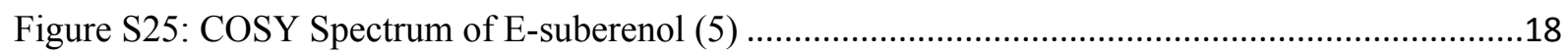

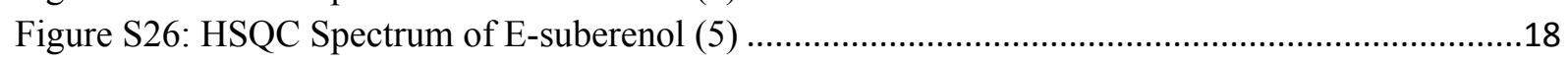

Figure S27: HMBC Spectrum of E-suberenol (5) ......................................................................19

Figure S28: ${ }^{1} \mathrm{H}$ NMR Spectrum (500 MHz, $\mathrm{CD}_{3} \mathrm{OD}$ ) of E-methoxysuberenol (6)..............................19

Figure S29: 135-DEPT Spectrum (125 MHz, $\left.\mathrm{CD}_{3} \mathrm{OD}\right)$ Spectrum of E-methoxysuberenol (6) ............20

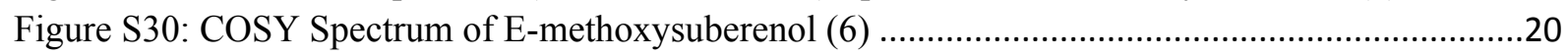

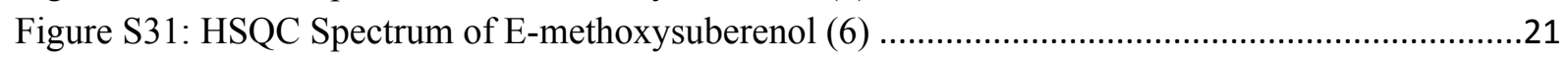

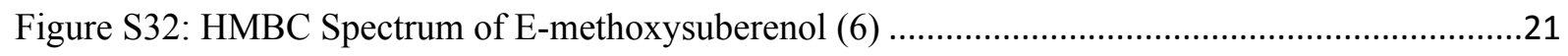

Figure S33: ${ }^{1} \mathrm{H}$ NMR Spectrum $\left(500 \mathrm{MHz}, \mathrm{CD}_{3} \mathrm{OD}\right)$ of Thamnosmonin (7) .....................................22

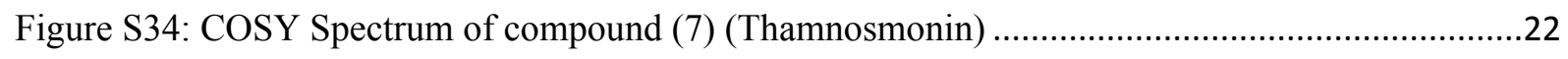

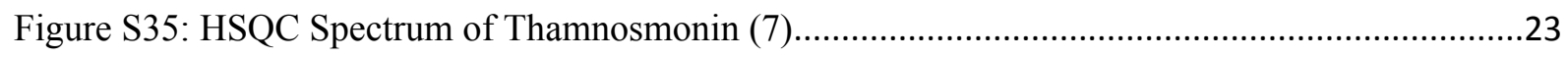

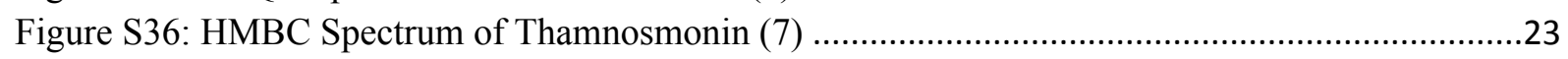

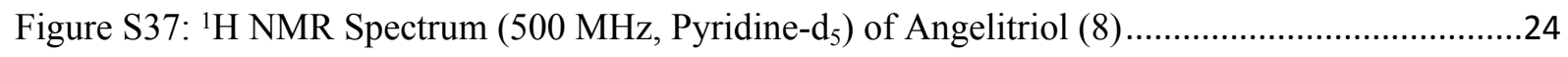

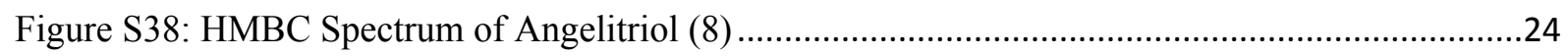

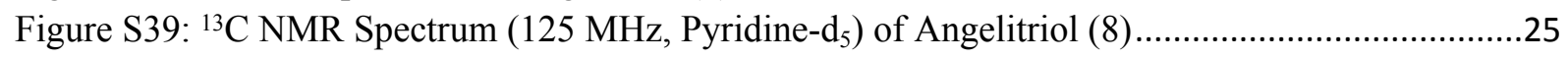

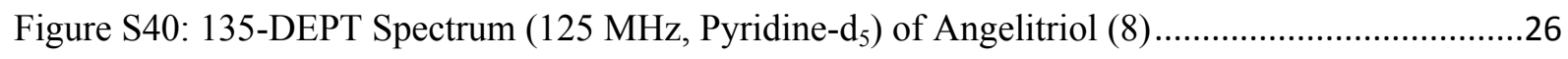

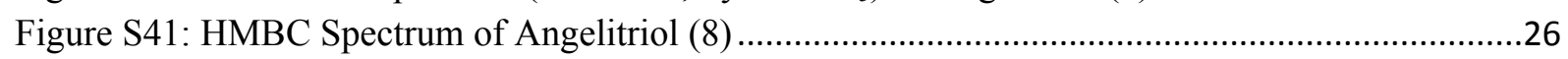

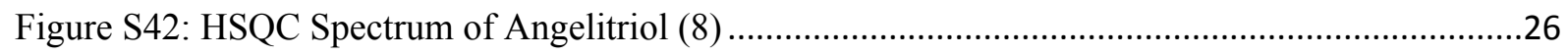

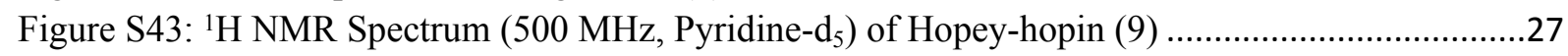

Figure S44: ${ }^{13} \mathrm{C}$ NMR Spectrum (125 MHz, Pyridine- $\mathrm{d}_{5}$ ) of Hopey-hopin (9) ..................................2

Figure S45: 135-DEPT Spectrum (125 MHz, Pyridine- $\mathrm{d}_{5}$ ) of Hopey-hopin (9) ................................28 


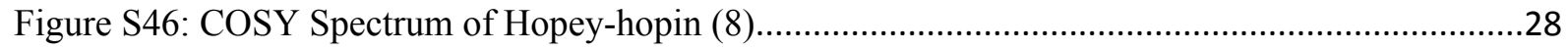

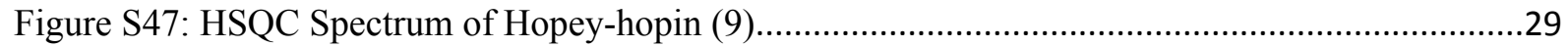

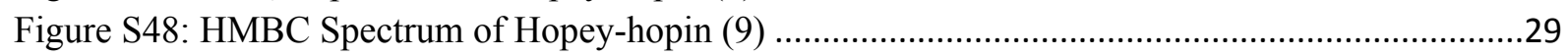

Figure S49: ${ }^{1} \mathrm{H}$ NMR Spectrum $\left(500 \mathrm{MHz}, \mathrm{CDCl}_{3}\right)$ of Formlylumbeliferone (10) .................................30

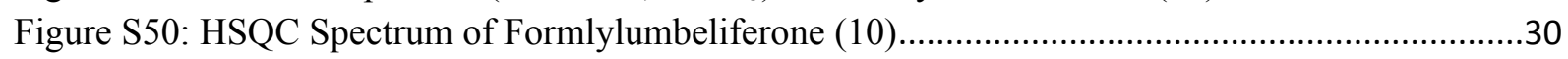

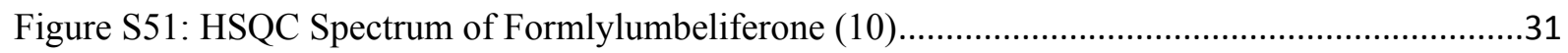

Figure S52: HMBC Spectrum of Formlylumbeliferone (10) ........................................................31

Figure S53: ' $\mathrm{H}$ NMR Spectrum (500 MHz, $\mathrm{CDCl}_{3}$ ) of 5-OH-6,7,8,4'-Tetrametoxyflavone (11).........32

Figure S54: COSY Spectrum of 5-OH-6,7,8,4'-Tetrametoxyflavone (11) ............................................32

Figure S55: HSQC Spectrum of 5-OH-6,7,8,4'-Tetrametoxyflavone (11) ...........................................33

Figure S56: ${ }^{13} \mathrm{C}$ NMR Spectrum (125 MHz, $\mathrm{CDCl}_{3}$ ) of compound (11) (5-OH-6,7,8,4'-

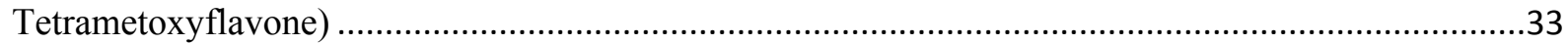

Figure S57: 135-DEPT Spectrum (125 MHz, $\mathrm{CDCl}_{3}$ ) of 5-OH-6,7,8,4'-Tetrametoxyflavone (11)......34

Figure S58: HMBC Spectrum of 5-OH-6,7,8,4'-Tetrametoxyflavone (11) ......................................34

Figure S59: ${ }^{1} \mathrm{H}$ NMR Spectrum (500 MHz, $\mathrm{CDCl}_{3}$ ) of 5-OH-6,7,8,3',4'-Pentametoxyflavone (12) ....35

Figure S60: COSY Spectrum of 5-OH-6,7,8,3',4'-Pentametoxyflavone (12) .....................................35

Figure S61: HSQC Spectrum of 5-OH-6,7,8,3',4'-Pentametoxyflavone (12) ....................................36

Figure S62: ${ }^{13} \mathrm{C}$ NMR Spectrum (125 MHz, $\mathrm{CDCl}_{3}$ ) of 5-OH-6,7,8,3',4'-Pentametoxyflavone (12) ...36

Figure S63: 135-DEPT Spectrum (125 MHz, $\mathrm{CDCl}_{3}$ ) of 5-OH-6,7,8,3',4'-Pentametoxyflavone (12).37

Figure S64: HMBC Spectrum of 5-OH-6,7,8,3',4'-Pentametoxyflavone (12)....................................37

Figure S65: ${ }^{1} \mathrm{H}$ NMR Spectrum (500 MHz, $\mathrm{CDCl}_{3}$ ) of 5,4'-d ihydroxy-6,7,3'-Trimetoxyflavone (13)38

Figure S66: HMBC Spectrum of 5,4'-d ihydroxy-6,7,3'-Trimetoxyflavone (13) ..............................38

Figure S67: HMBC Spectrum of 5,4'-d ihydroxy-6,7,3'-Trimetoxyflavone (13) ..................................39

Figure S68: HMBC Spectrum of 5,4'-d ihydroxy-6,7,3'-Trimetoxyflavone (13) ...............................39

Figure S69: ${ }^{13} \mathrm{CNMR}$ Spectrum (125 MHz, $\mathrm{CDCl}_{3}$ ) of 5,4'-d ihydroxy-6,7,3'-Trimetoxyflavone (13)

Figure S70: 135-DEPT Spectrum (125MHz, $\left.\mathrm{CDCl}_{3}\right)$ of 5,4'-d ihydroxy-6,7,3'-Trimetoxyflavone (13)

Figure S71: ${ }^{1} \mathrm{H}$ NMR Spectrum (500 MHz, $\mathrm{CDCl}_{3}$ ) of 5,4'-dihydroxy-6,7,8,3'-Tetrametoxyflavone (14)

Figure S72: COSY Spectrum of 5,4'-dihydroxy-6,7,8,3'-Tetrametoxyflavone (14).............................41

Figure S73: HSQC Spectrum of 5,4'-dihydroxy-6,7,8,3'-Tetrametoxyflavone (14)...........................42

Figure S74: HMBC Spectrum of 5,4'-dihydroxy-6,7,8,3'-Tetrametoxyflavone (14)..........................42

Figure S75: ${ }^{13} \mathrm{C}$ NMR Spectrum (125 MHz, $\mathrm{CDCl}_{3}$ ) of 5,4'-dihydroxy-6,7,8,3'-Tetrametoxyflavone

(14)

Figure S76: 135-DEPT Spectrum (125 MHz, $\mathrm{CDCl}_{3}$ ) of 5,4'-dihydroxy-6,7,8,3'-Tetrametoxyflavone

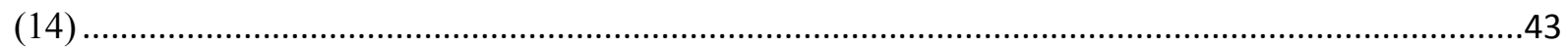

Figure S77: ${ }^{1} \mathrm{H}$ NMR Spectrum (500 MHz, Pyridin-d $\mathrm{d}_{5}$ ) of 5,6,7,8,4'-Pentametoxyflavone (15) ..........44

Figure S78: COSY Spectrum of 5,6,7,8,4'-Pentametoxyflavone (15) …...........................................

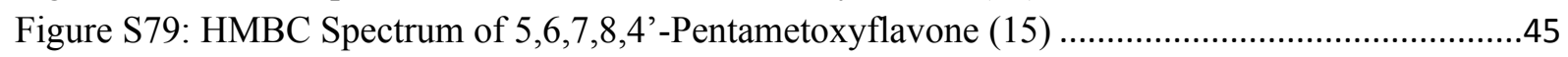

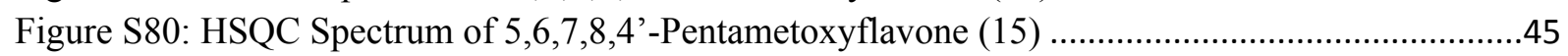

Figure S81: ${ }^{13} \mathrm{C}$ NMR Spectrum (125 MHz, Pyridin-d $\mathrm{d}_{5}$ ) of 5,6,7,8,4'-Pentametoxyflavone (15) .........46

Figure S82: 135-DEPT Spectrum (125 MHz, Pyridin-d d $_{5}$ of 5,6,7,8,4'-Pentametoxyflavone (15) .......46

Figure S83: ${ }^{1} \mathrm{H}$ NMR Spectrum $\left(500 \mathrm{MHz}\right.$, Aceton- $\mathrm{d}_{6}$ ) of Atalantaflavone (17) ...............................47

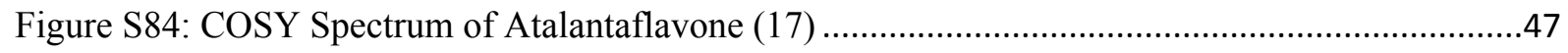

Figure S85: ${ }^{13} \mathrm{C}$ NMR Spectrum (125 MHz, Aceton-d $\mathrm{d}_{6}$ ) of Atalantaflavone (17) ................................48

Figure S86: 135-DEPT Spectrum (125 MHz, Aceton- $\mathrm{d}_{6}$ ) of Atalantaflavone (17) ................................48

Figure S87: HMBC Spectrum of Atalantaflavone (17) ................................................................. 


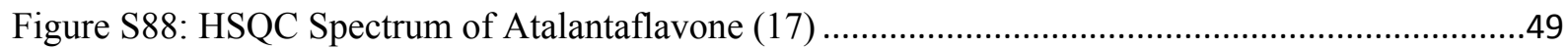

Figure S89: ${ }^{1} \mathrm{H}$ NMR Spectrum $\left(500 \mathrm{MHz}, \mathrm{CDCl}_{3}\right.$ ) of 5-hydroxynoracronycine (18)..........................50

Figure S90: ${ }^{13} \mathrm{C}$ NMR Spectrum $\left(125 \mathrm{MHz}, \mathrm{CDCl}_{3}\right.$ ) of 5-hydroxynoracronycine (18) .......................50

Figure S91: COSY Spectrum of 5-hydroxynoracronycine (18) ........................................................51

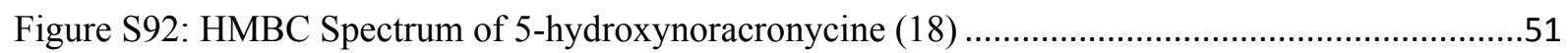

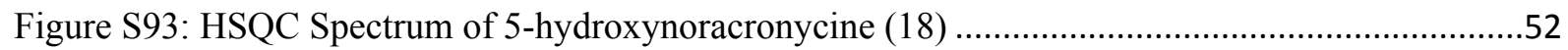

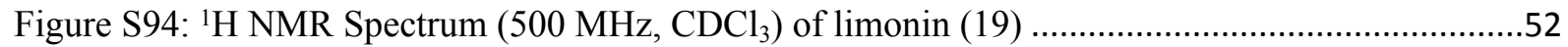

Figure S95: ${ }^{13} \mathrm{C}$ NMR Spectrum (125 MHz, $\mathrm{CDCl}_{3}$ ) of limonin (19) ..............................................53

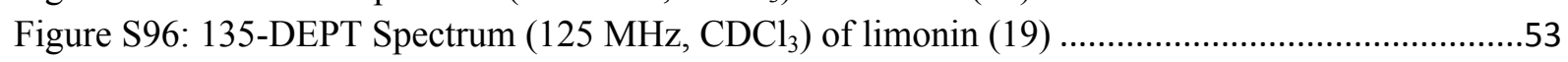

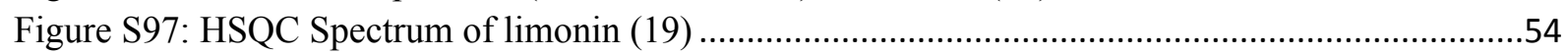

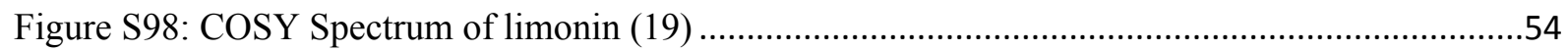

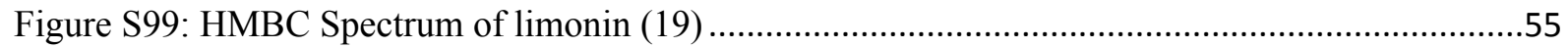

Figure S100: ${ }^{1} \mathrm{H}$ NMR Spectrum $\left(500 \mathrm{MHz}, \mathrm{CDCl}_{3}\right.$ ) of 1-(10-19) abeo-7 $\alpha$-Acetoxy-10ß-

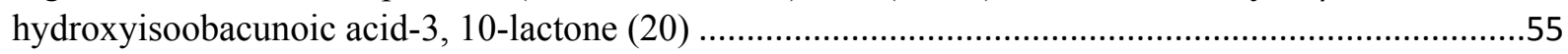

Figure S101: ${ }^{13} \mathrm{C}$ NMR Spectrum $\left(125 \mathrm{MHz}, \mathrm{CDCl}_{3}\right)$ of 1-(10-19) abeo-7 $\alpha$-Acetoxy-10 $\beta$ -

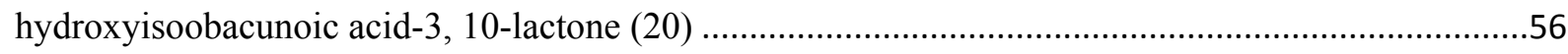

Figure S102: 135-DEPT Spectrum (125 MHz, $\left.\mathrm{CDCl}_{3}\right)$ of 1-(10-19) abeo-7 $\alpha$-Acetoxy-10 $\beta$ -

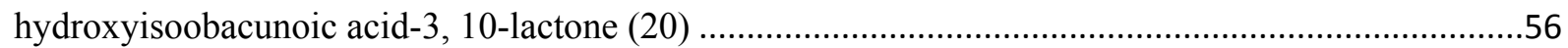

Figure S103: COSY Spectrum of 1-(10-19) abeo-7 $\alpha$-Acetoxy-10ß-hydroxyisoobacunoic acid-3, 10-

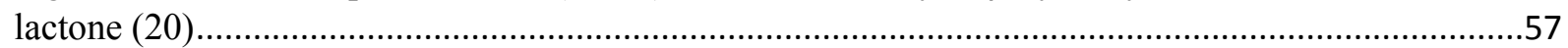

Figure S104: HSQC Spectrum of 1-(10-19) abeo-7 $\alpha$-Acetoxy-10ß-hydroxyisoobacunoic acid-3, 10-

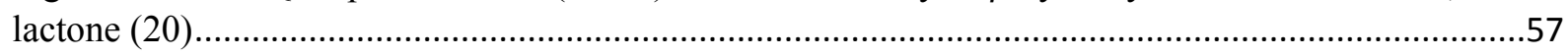

Figure S105: HMBC Spectrum of 1-(10-19) abeo-7 $\alpha$-Acetoxy-10ß-hydroxyisoobacunoic acid-3, 10-

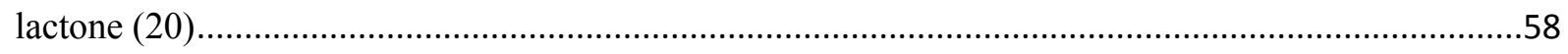

Figure S106: ${ }^{1} \mathrm{H}$ NMR Spectrum $\left(500 \mathrm{MHz}, \mathrm{CDCl}_{3}\right.$ ) of Asperfenamate (21) ...................................58

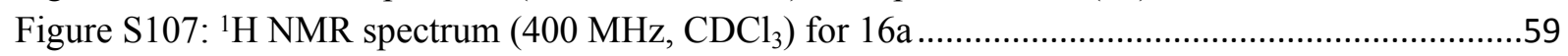

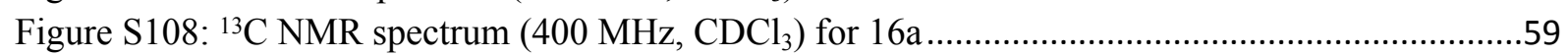

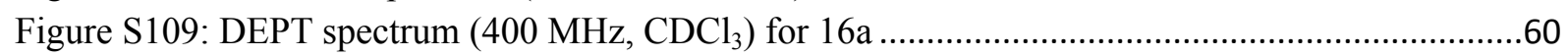

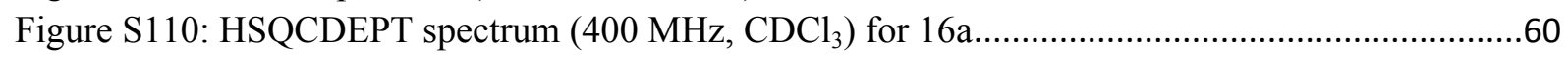

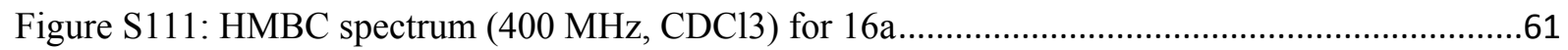

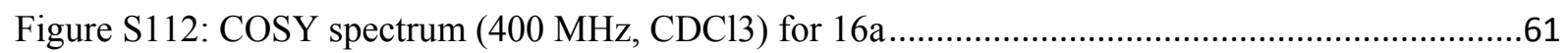

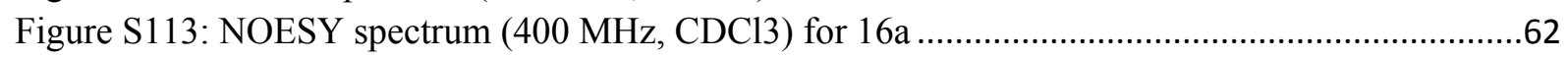

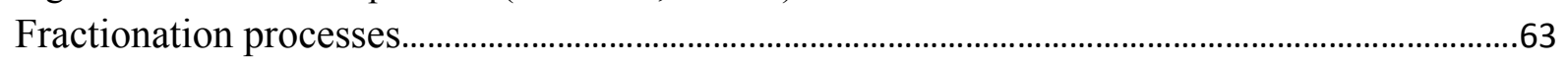

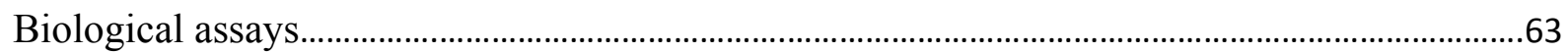




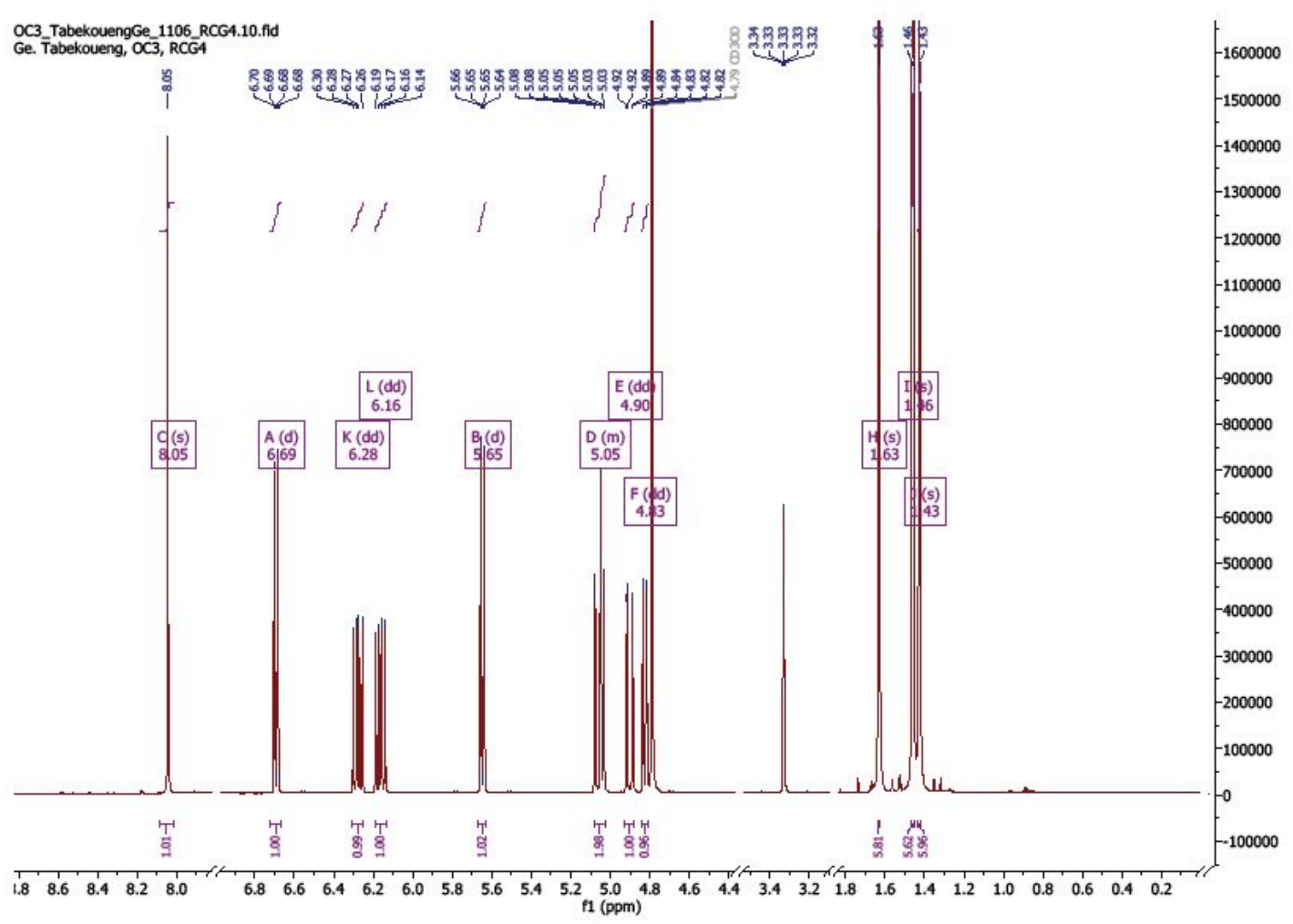

Figure S1: ${ }^{1} \mathrm{H}$ NMR Spectrum (500 MHz, $\mathrm{CDCl}_{3}$ ) of Clausarin (1)

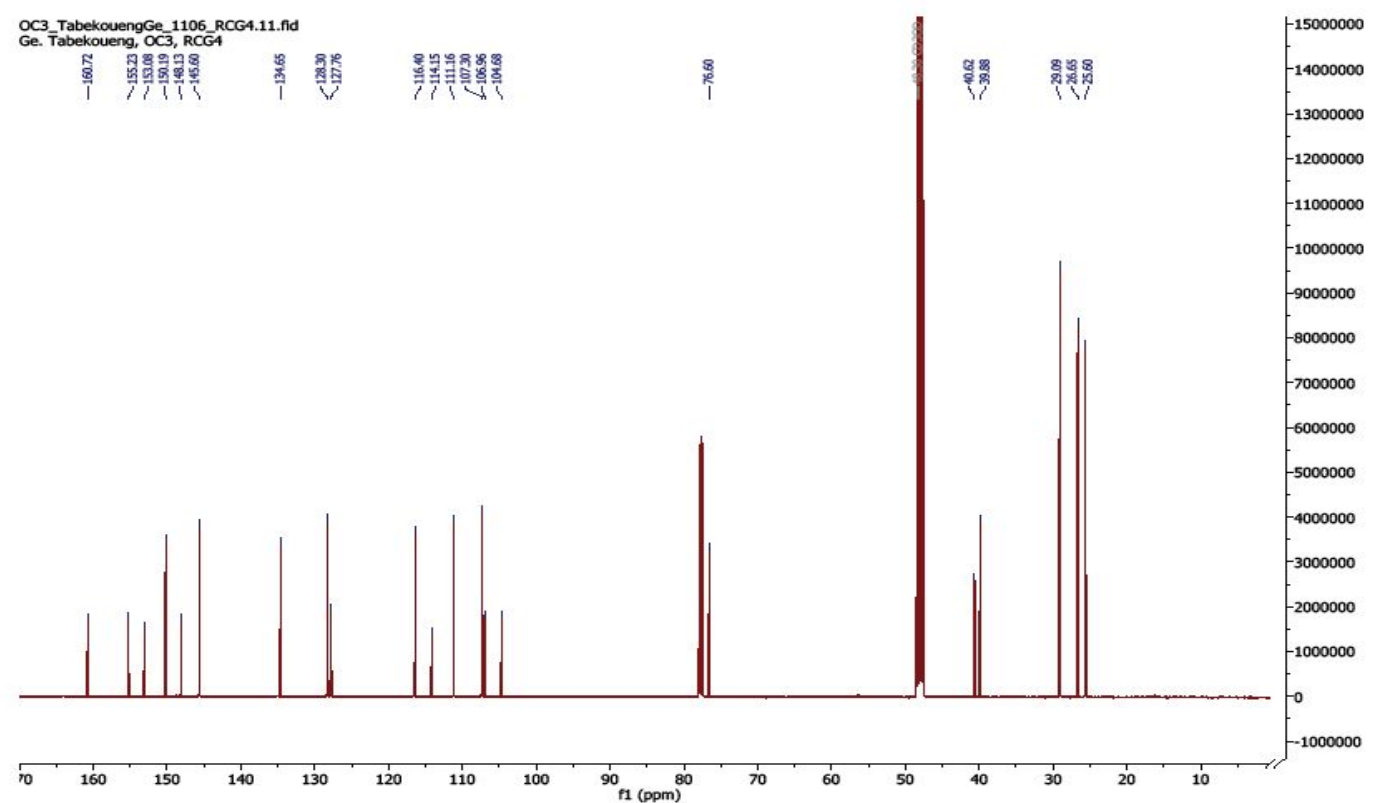

Figure S2: ${ }^{13} \mathrm{C}$ NMR Spectrum (125 $\mathrm{MHz}, \mathrm{CDCl}_{3}$ ) of Clausarin (1) 


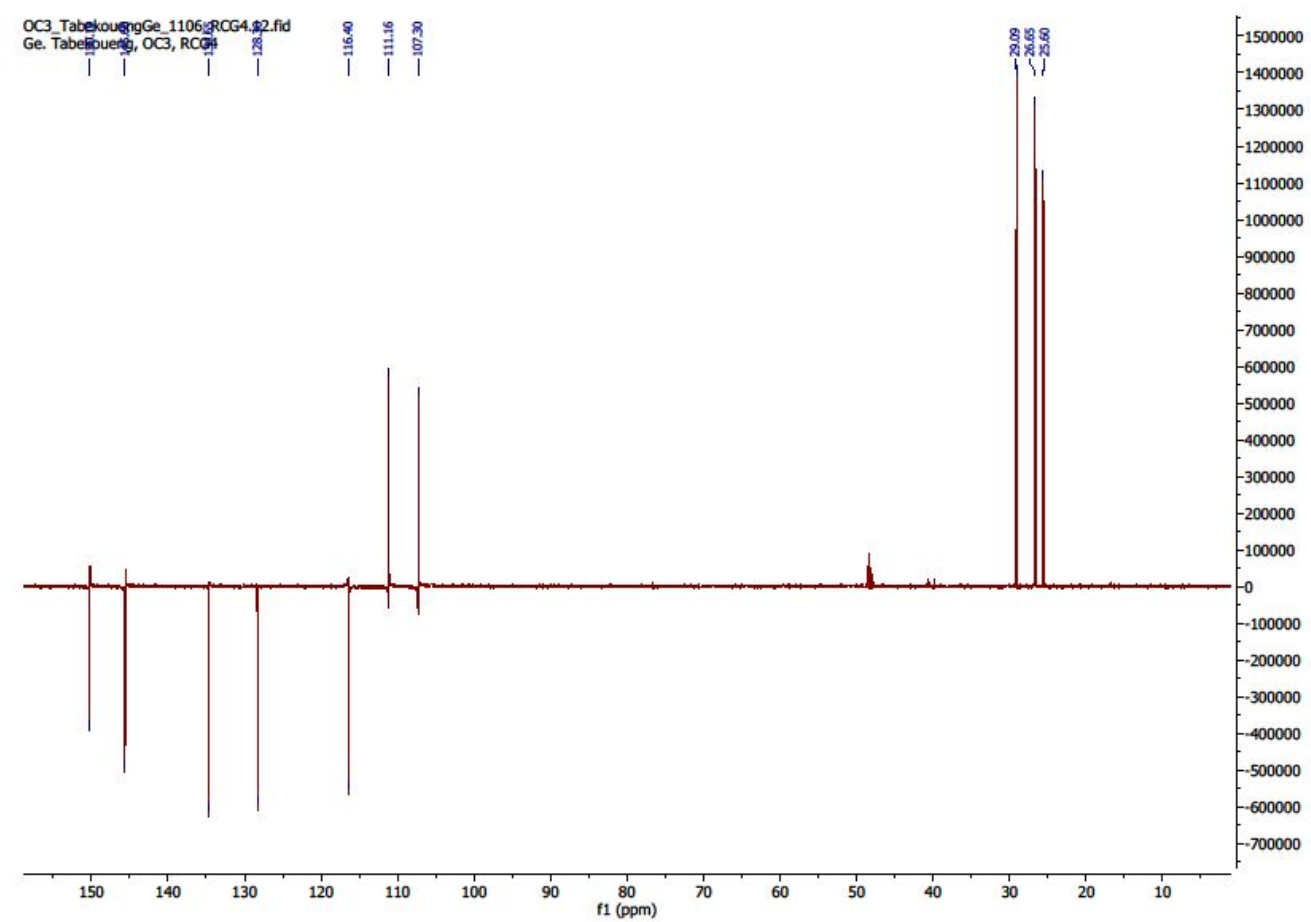

Figure S3: 135-DEPT (125 MHz, $\left.\mathrm{CDCl}_{3}\right)$ Spectrum of Clausarin (1)

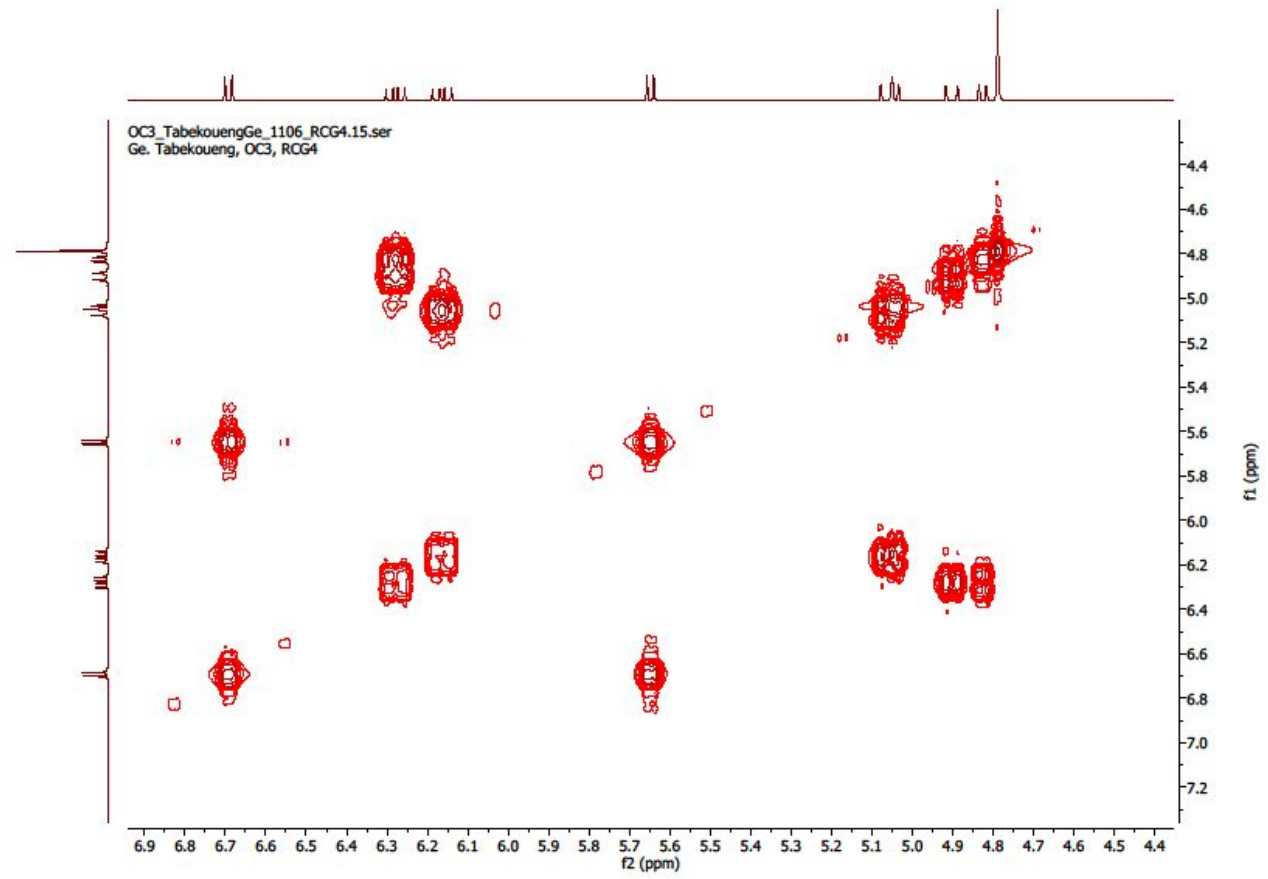

Figure S4: COSY Spectrum of Clausarin (1) 


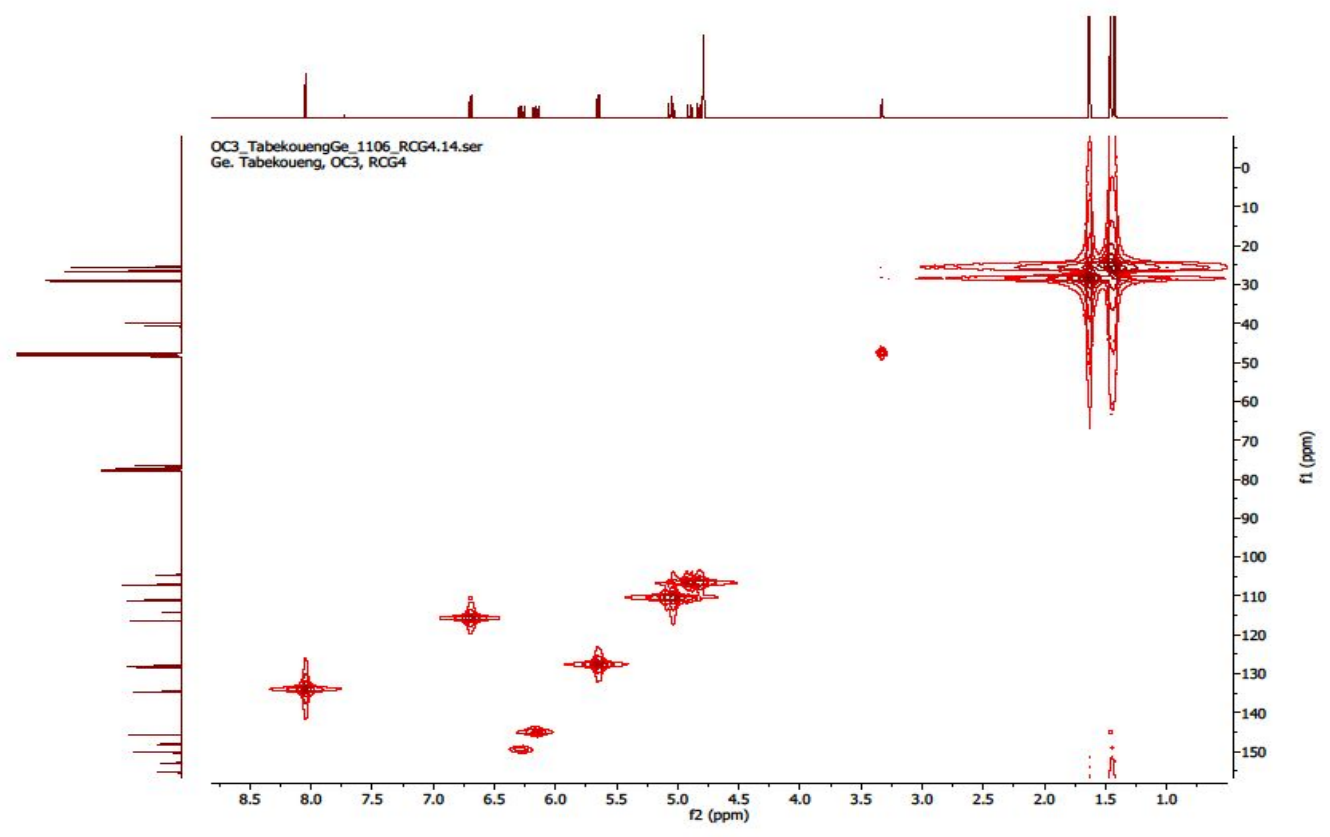

Figure S5: HSQC Spectrum of Clausarin (1)

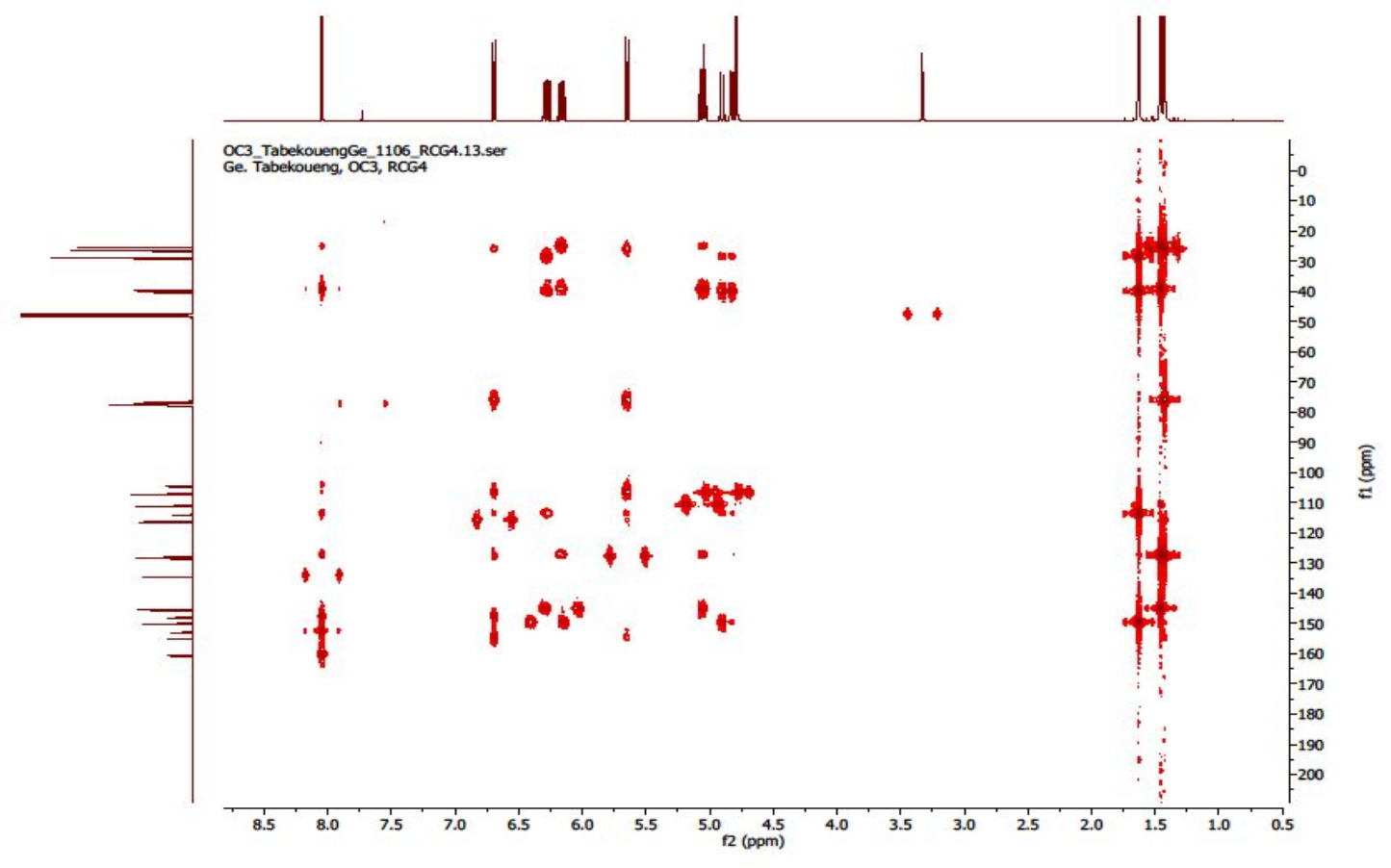

Figure S6: HMBC Spectrum of Clausarin (1) 


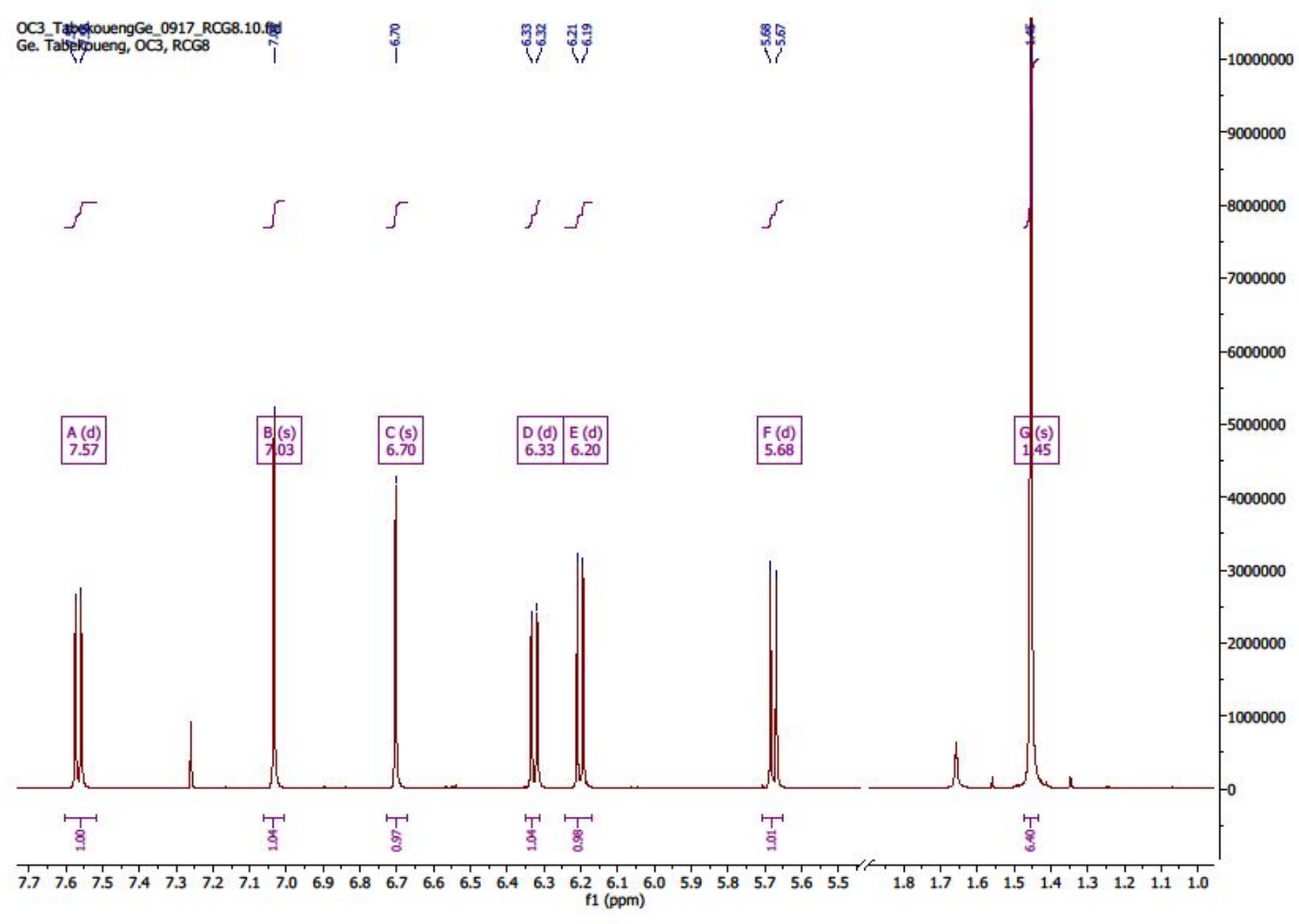

Figure S7: ${ }^{1} \mathrm{H}$ NMR Spectrum $\left(500 \mathrm{MHz}, \mathrm{CDCl}_{3}\right)$ of Xanthyletin (2)

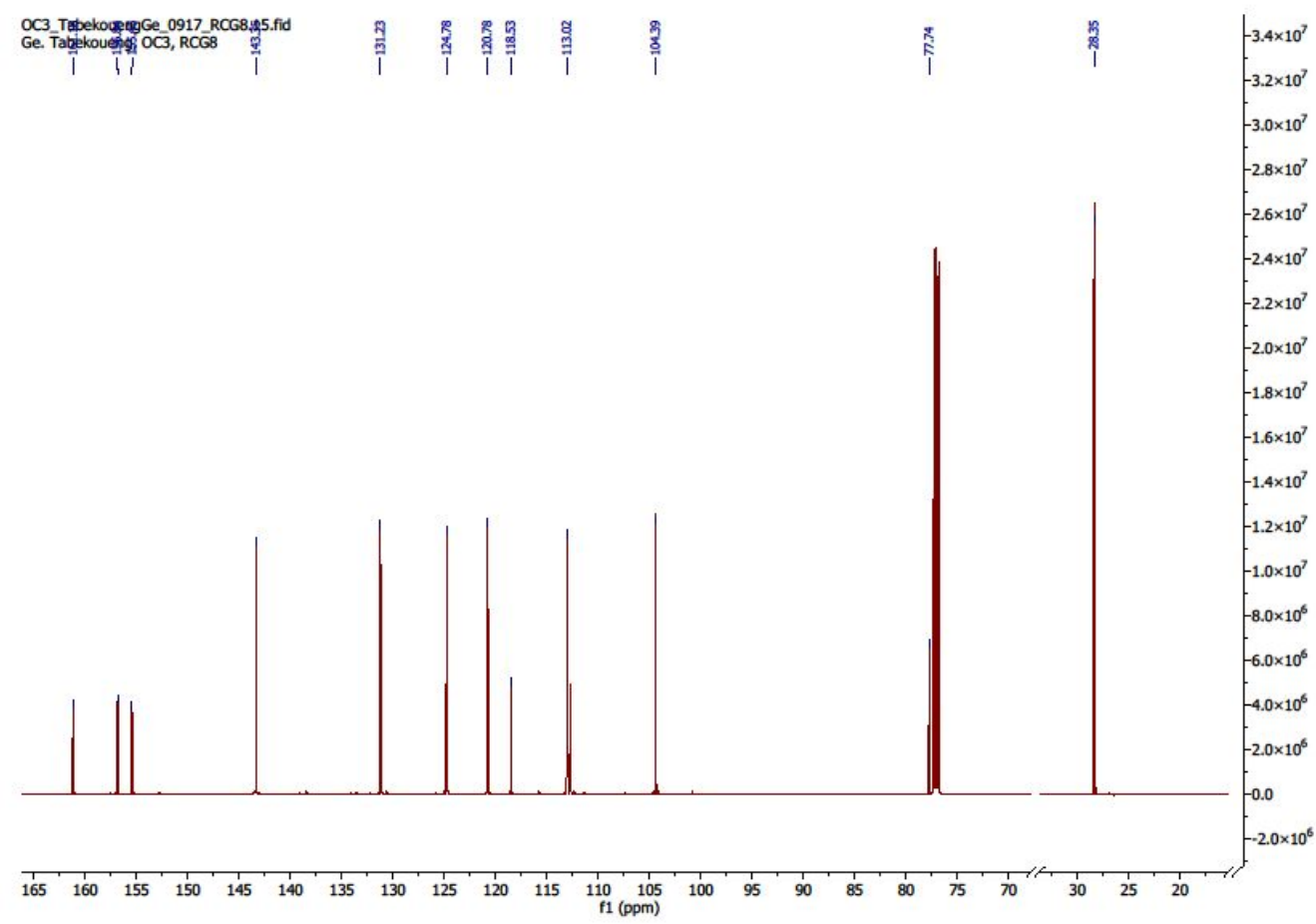

Figure S8: ${ }^{13} \mathrm{C}$ NMR Spectrum (125 $\mathrm{MHz}, \mathrm{CDCl}_{3}$ ) of Xanthyletin (2) 


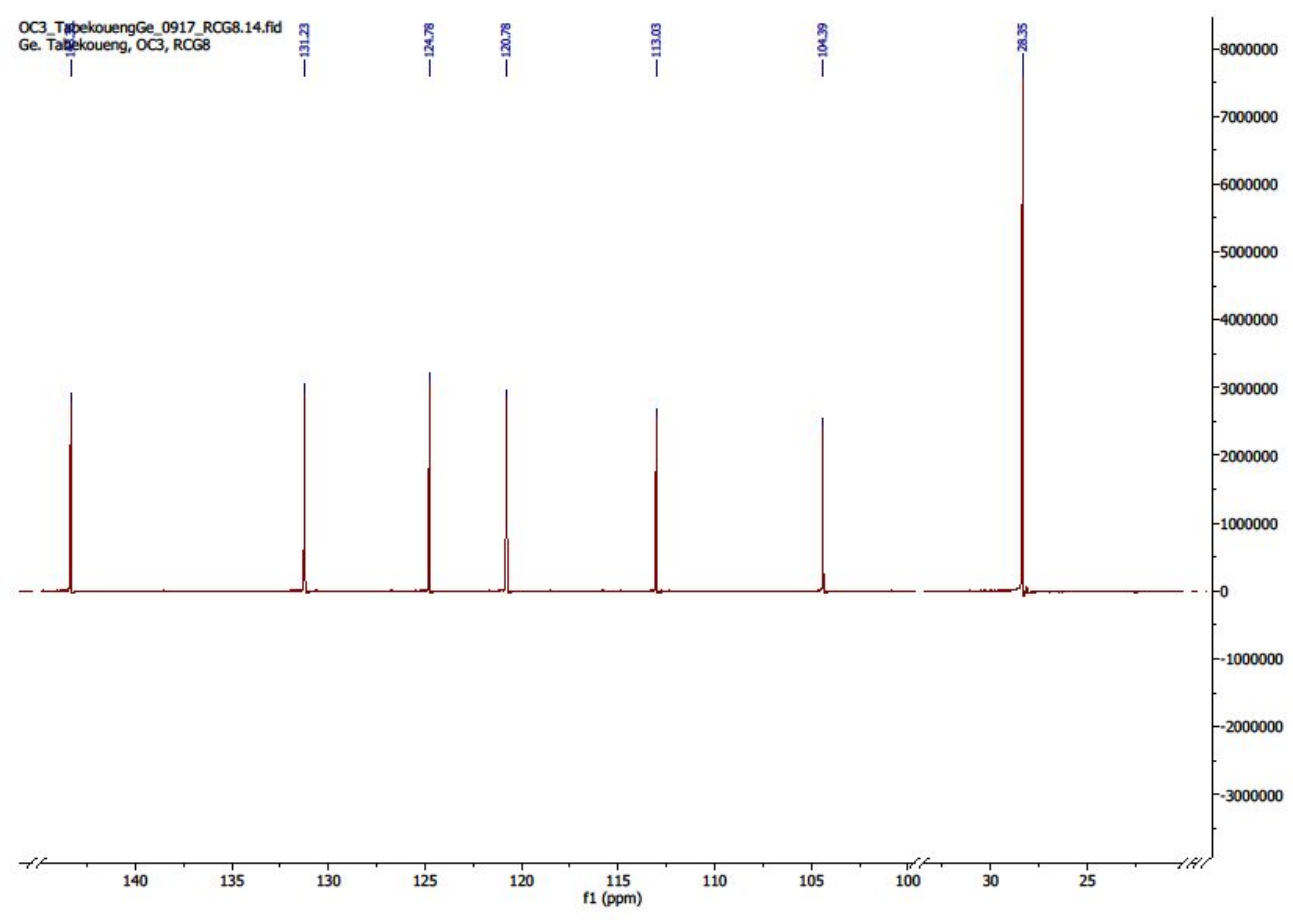

Figure S9: 135-DEPT Spectrum (125 MHz, $\mathrm{CDCl}_{3}$ ) of Xanthyletin (2)

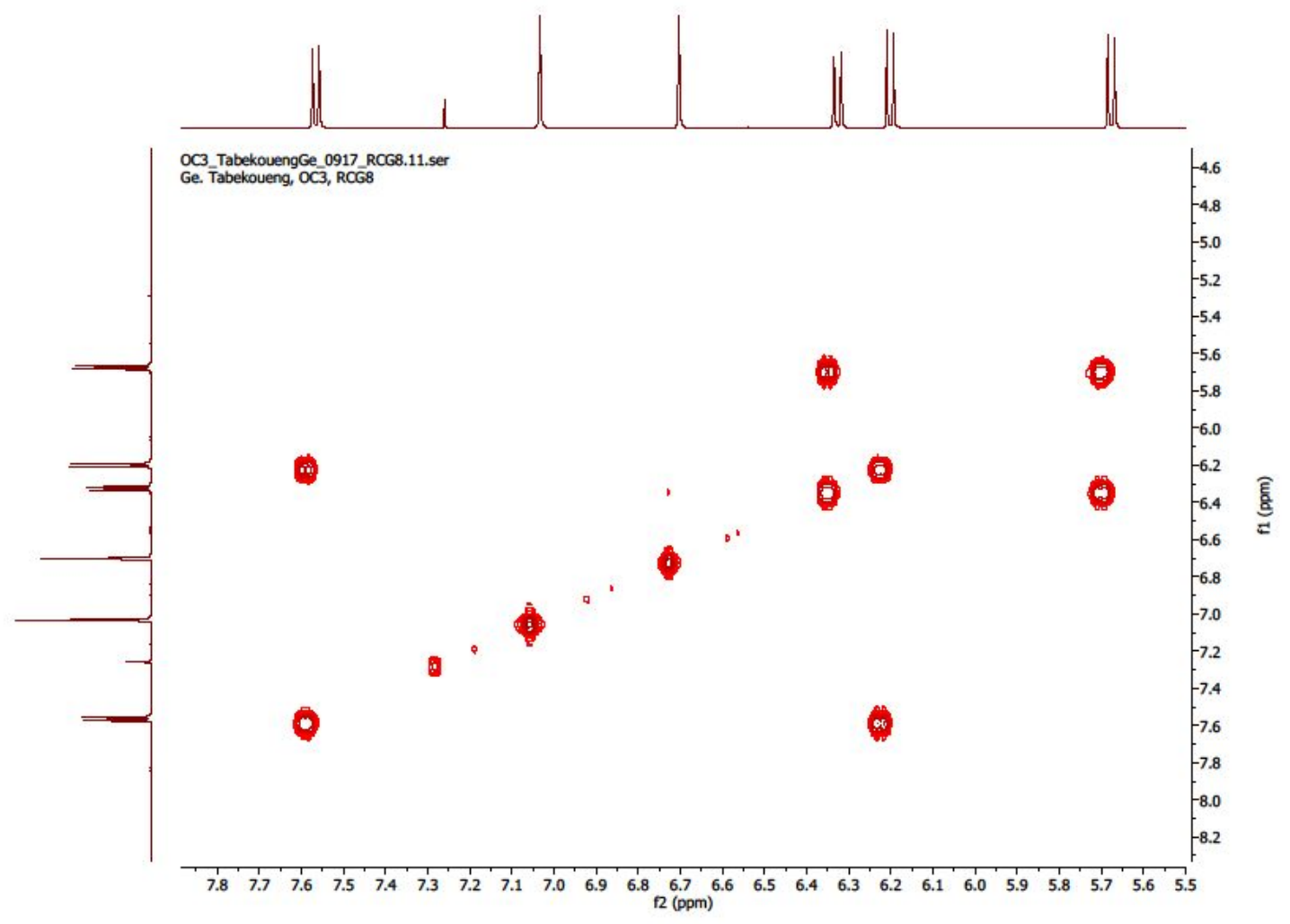

Figure S10: COSY Spectrum of Xanthyletin (2) 


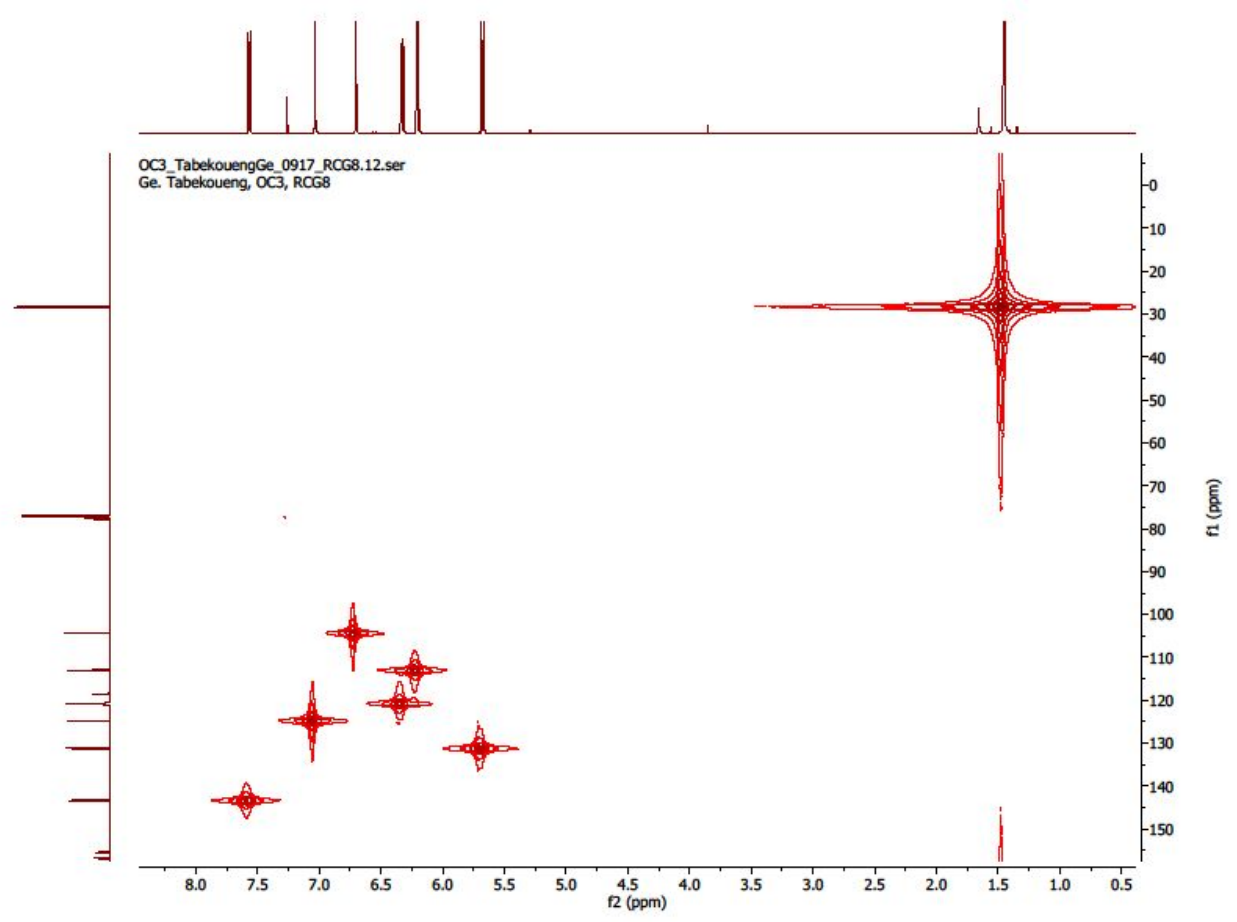

Figure S11: HSQC Spectrum of Xanthyletin (2)

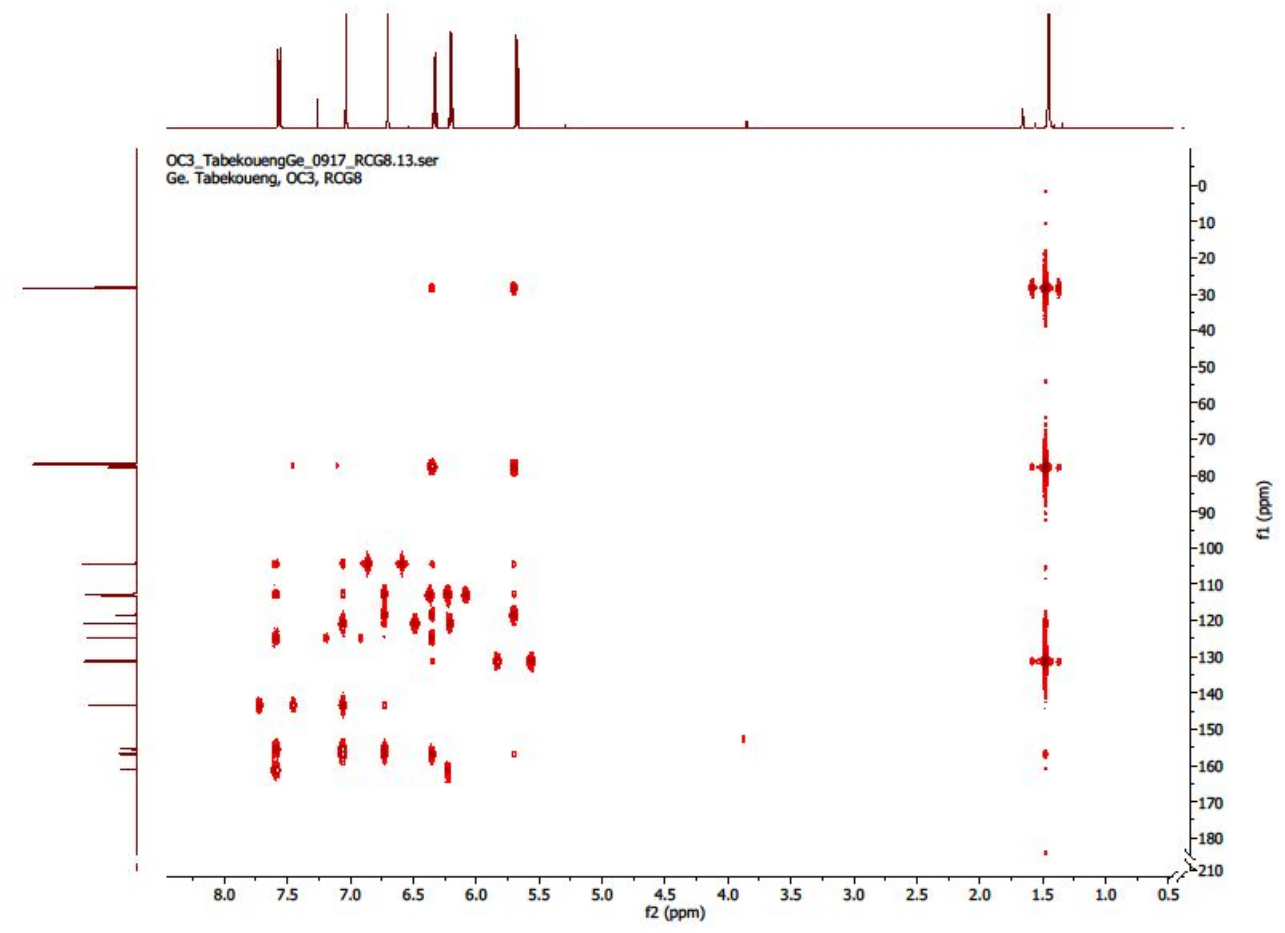

Figure S12: HMBC Spectrum of Xanthyletin (2) 


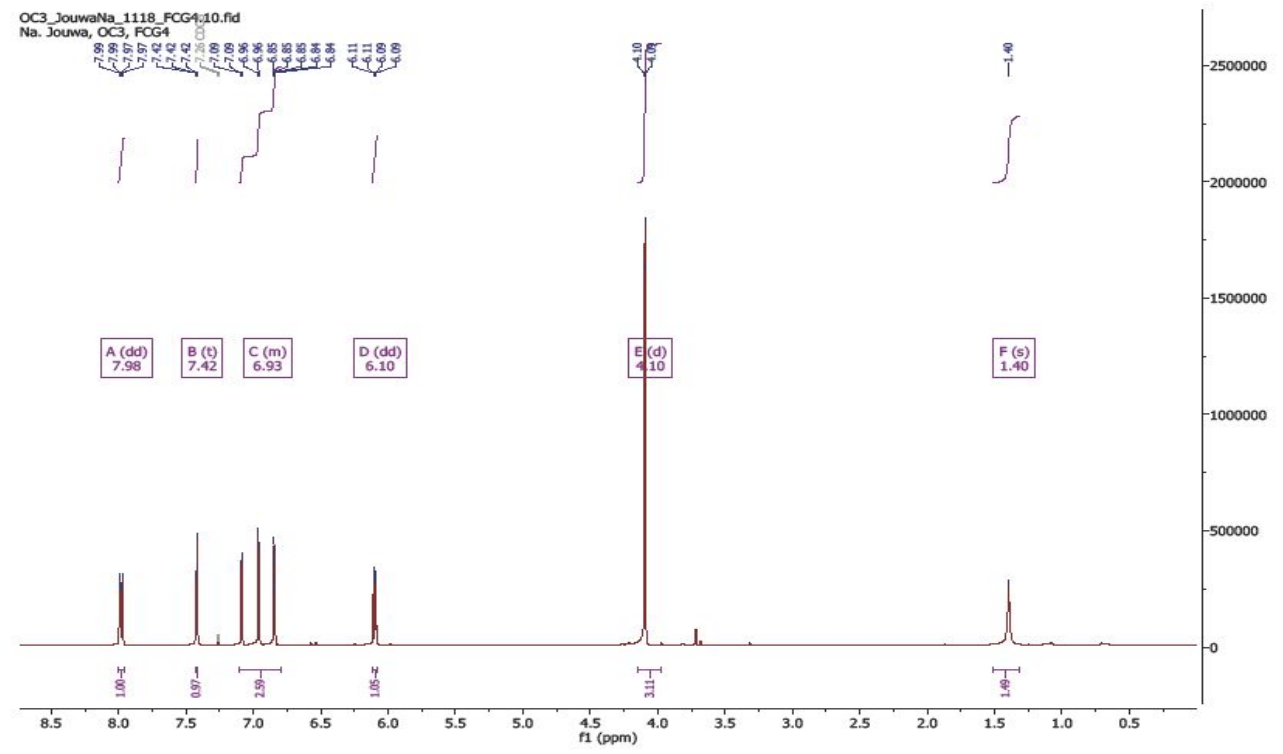

Figure S13: ${ }^{1} \mathrm{HNMR}$ Spectrum (500 MHz, $\mathrm{CDCl}_{3}$ ) of Bergaptin (3)

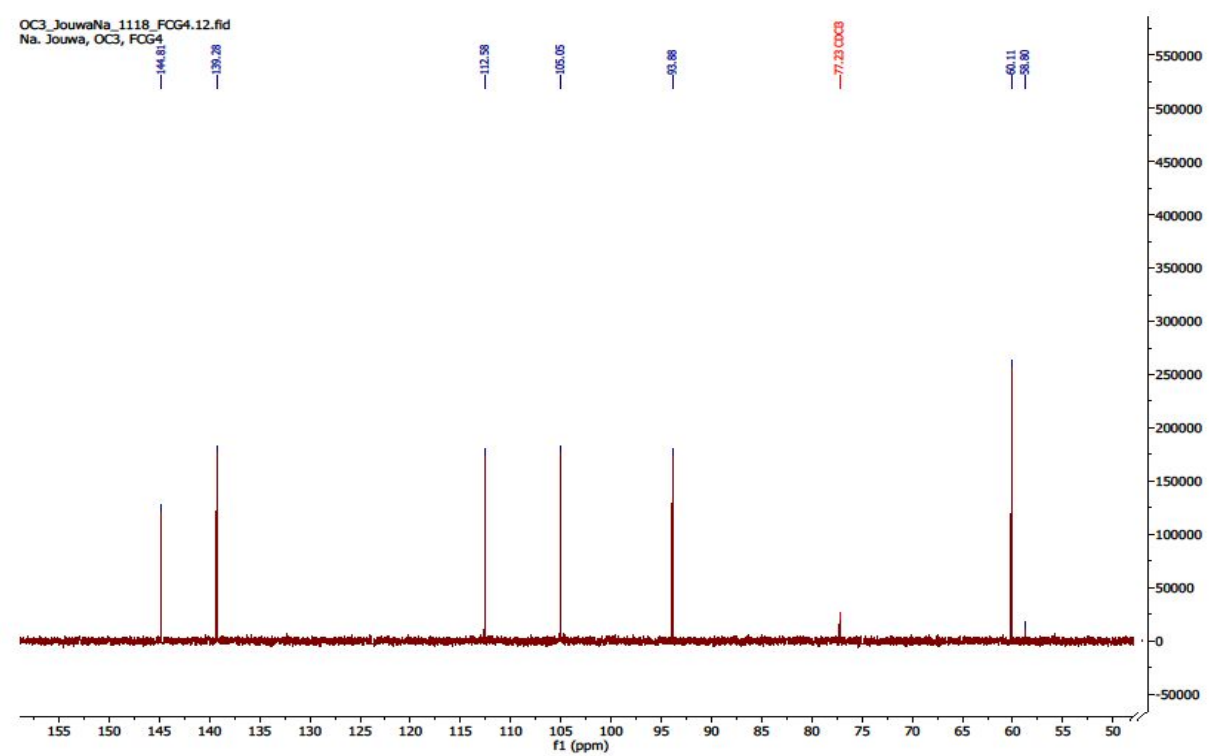

Figure S14: 135-DEPT Spectrum (125 MHz, $\left.\mathrm{CDCl}_{3}\right)$ of Bergaptin (3) 


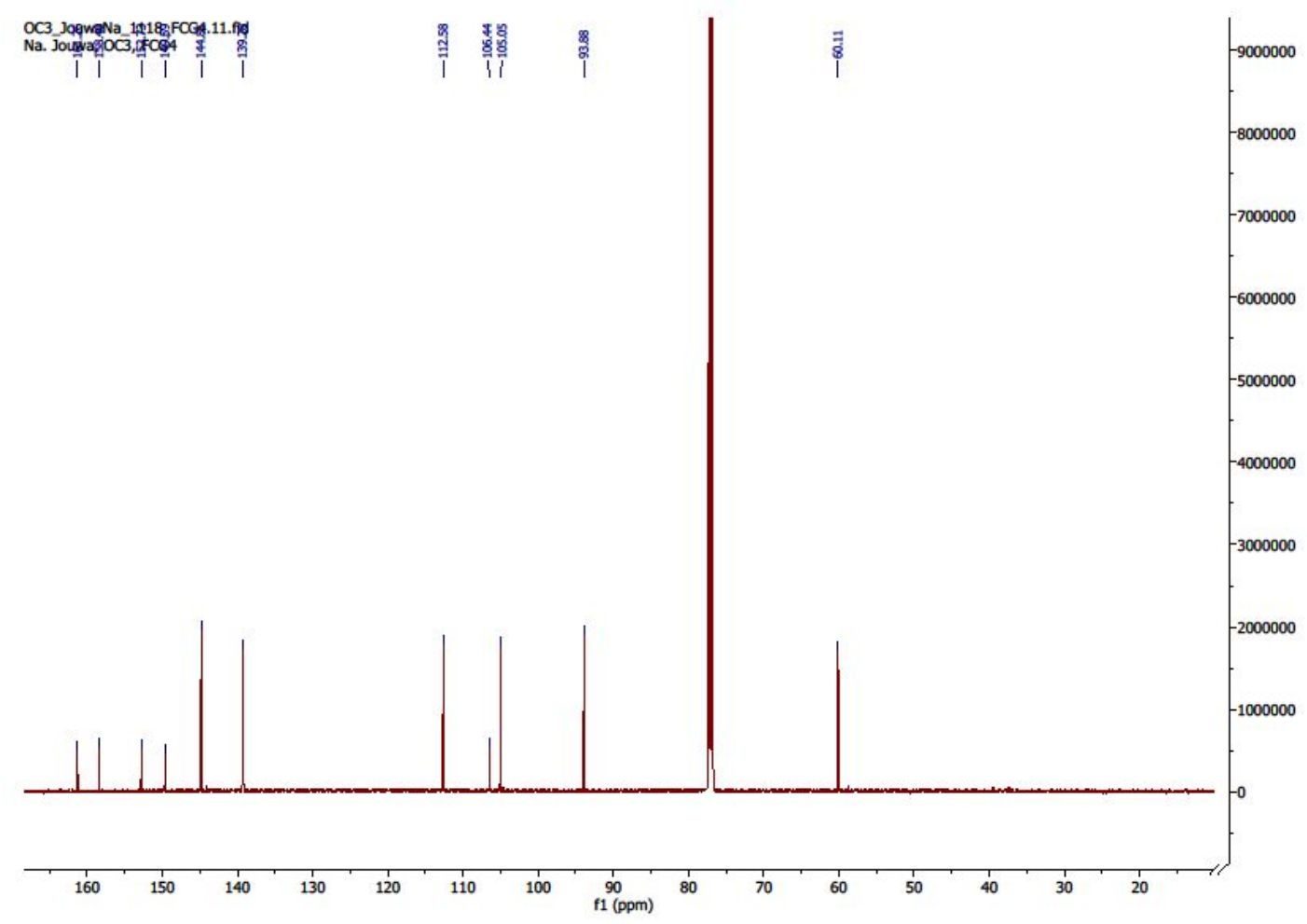

Figure S15: ${ }^{13} \mathrm{C} N M R$ Spectrum (125 MHz, $\mathrm{CDCl}_{3}$ ) of Bergaptin (3)

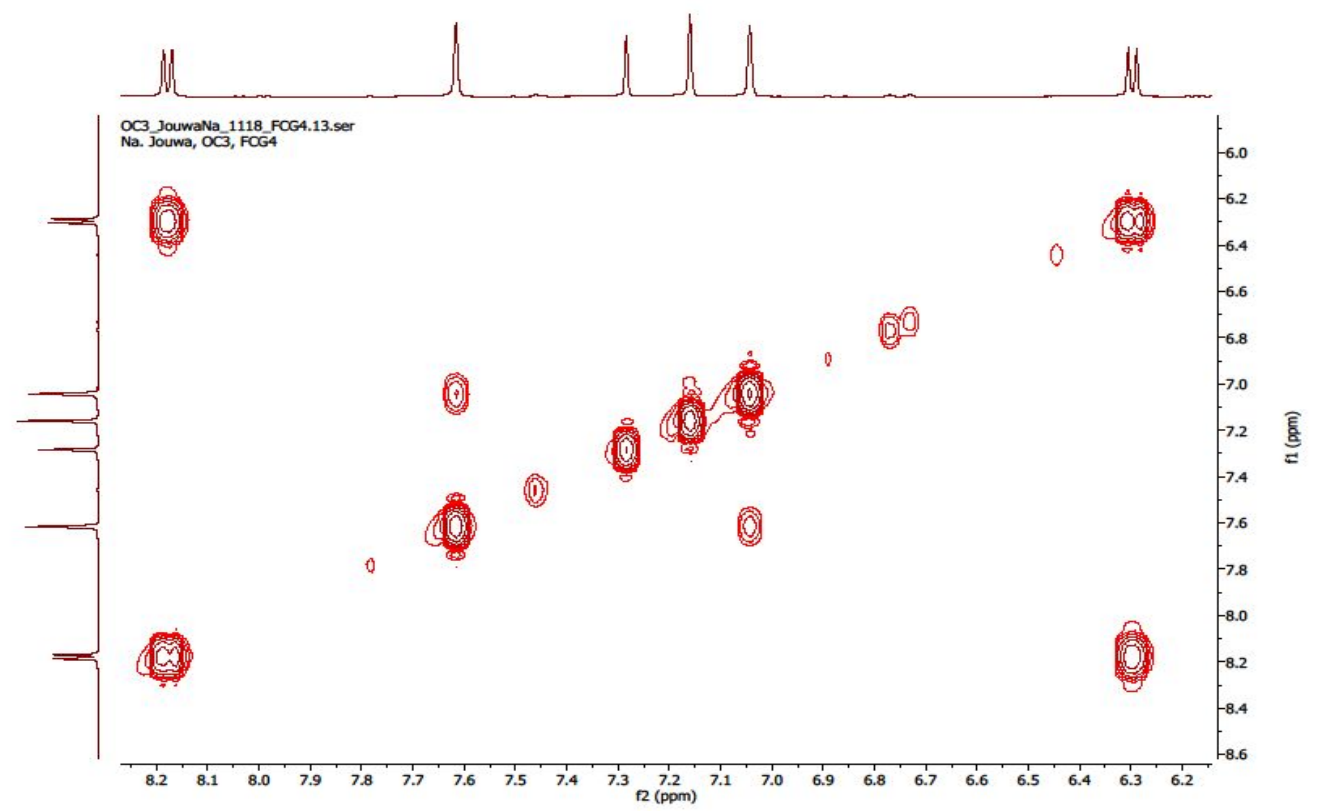

Figure S16: COSY Spectrum of Bergaptin (3) 


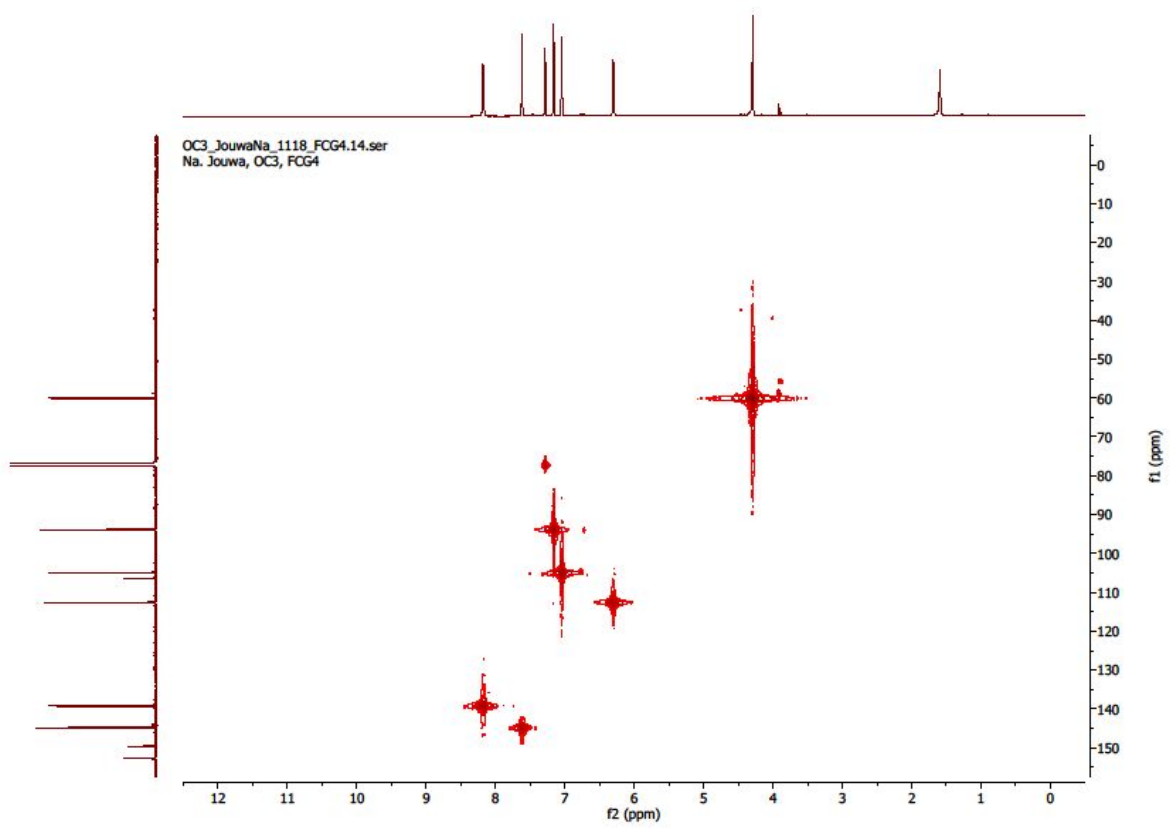

Figure S17: HSQC Spectrum of Bergaptin (3)

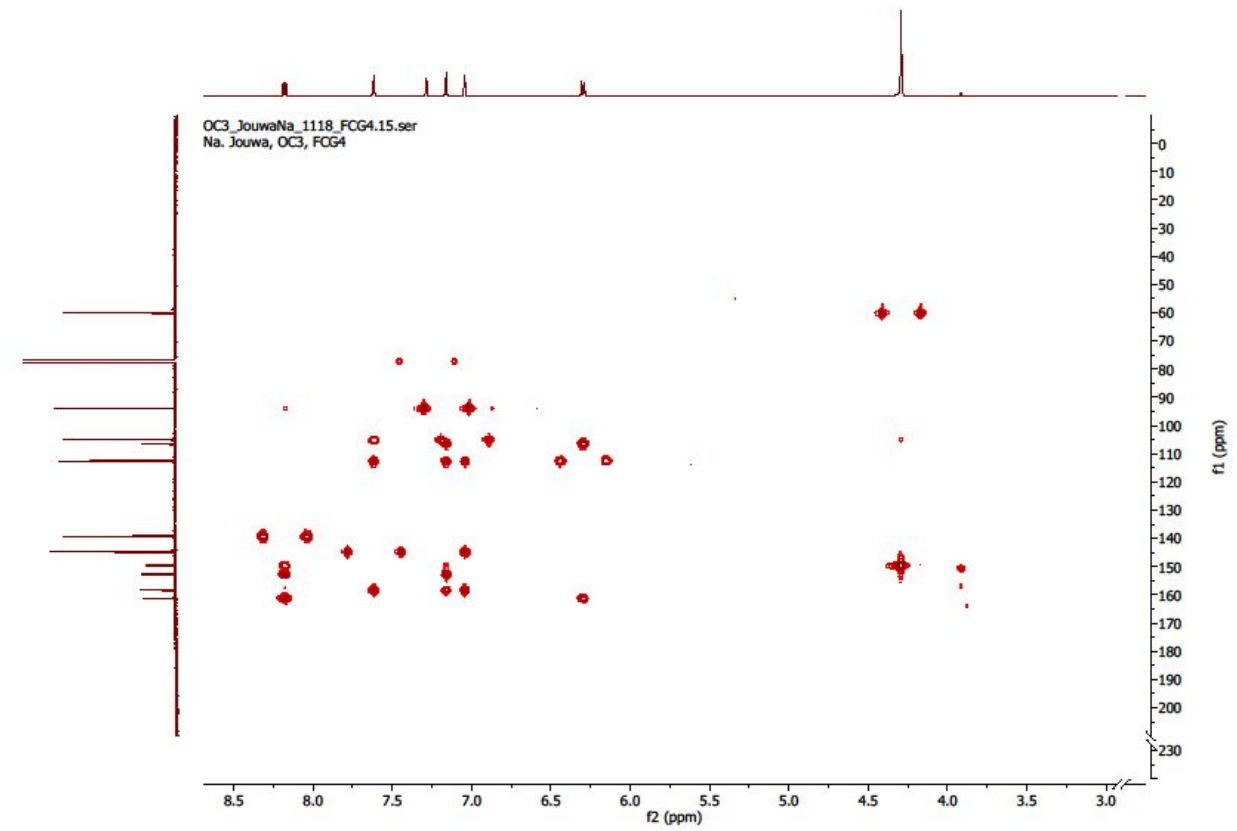

Figure S18: HMBC Spectrum of Bergaptin (3) 


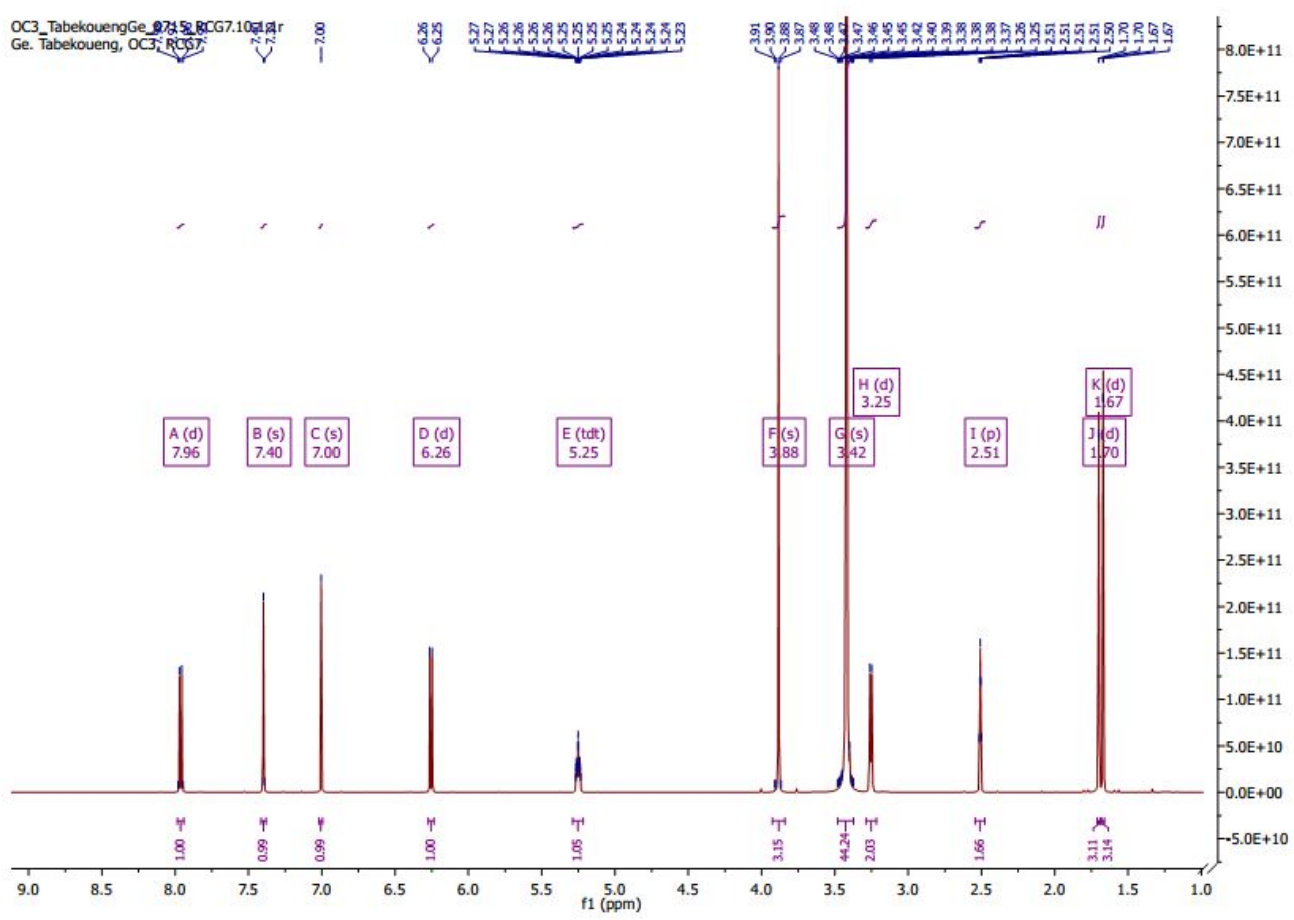

Figure S19: ${ }^{1} \mathrm{H} \mathrm{NMR}$ Spectrum (500 MHz, $\mathrm{CDCl}_{3}$ ) of Suberosin (4)

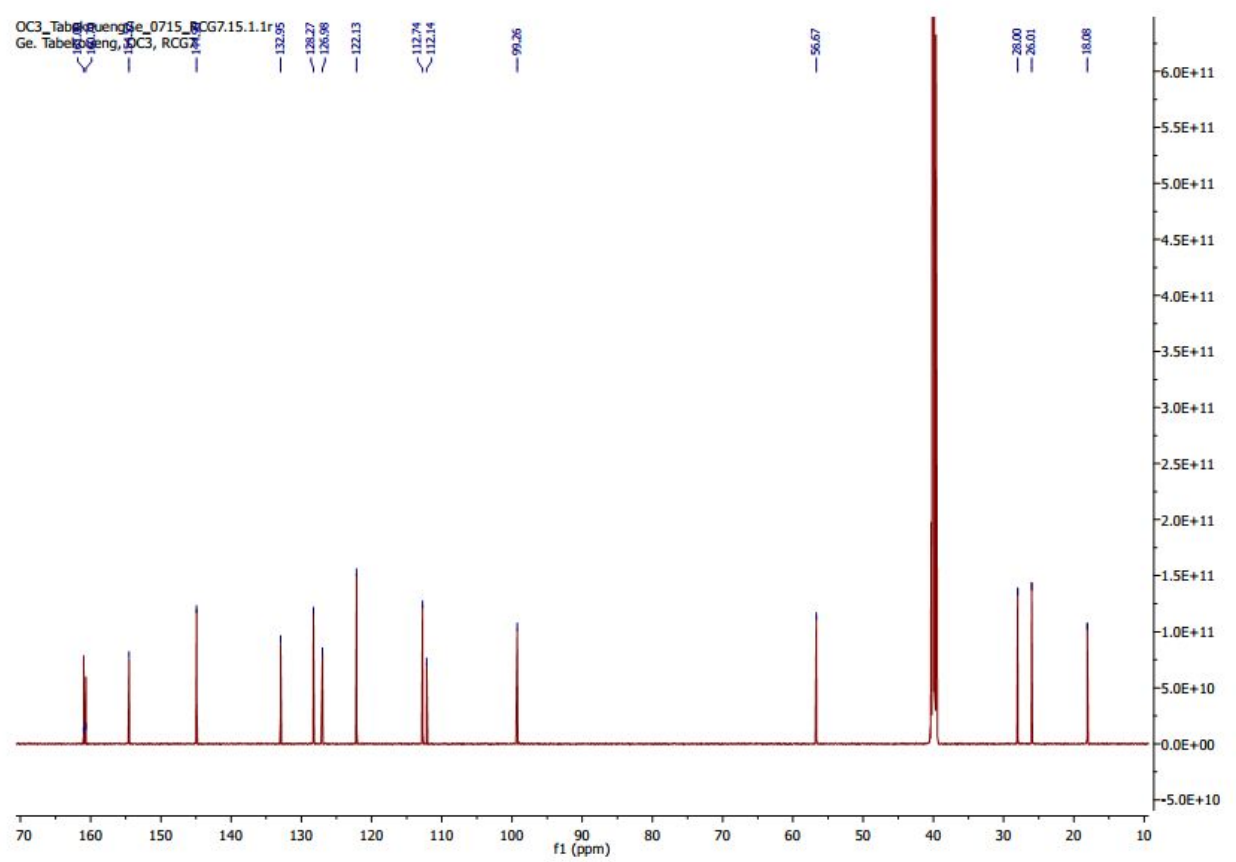

Figure S20: ${ }^{13} \mathrm{C}$ NMR Spectrum (125 MHz, $\mathrm{CDCl}_{3}$ ) of Suberosin (4) 


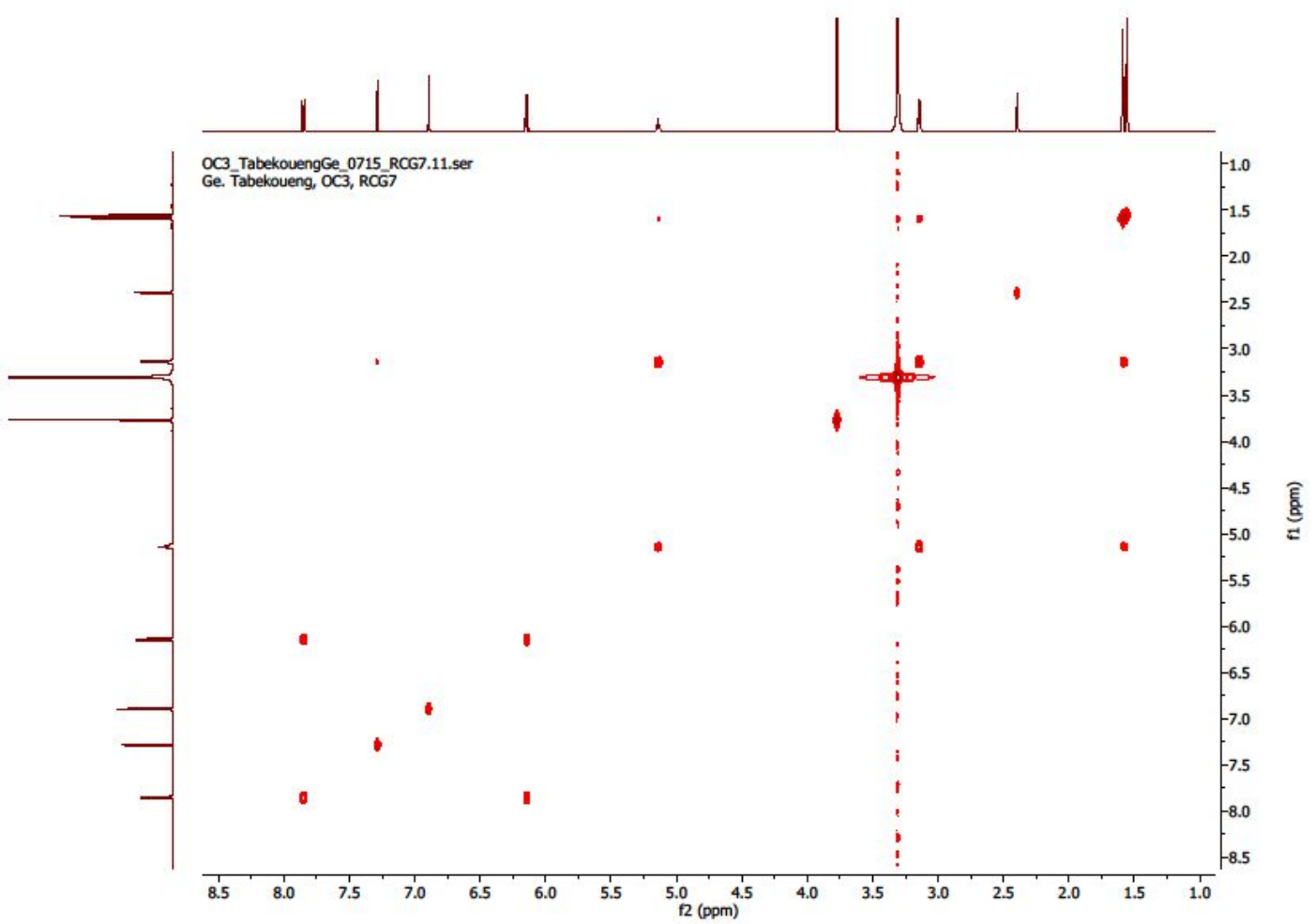

Figure S21: COSY Spectrum of Suberosin (4)

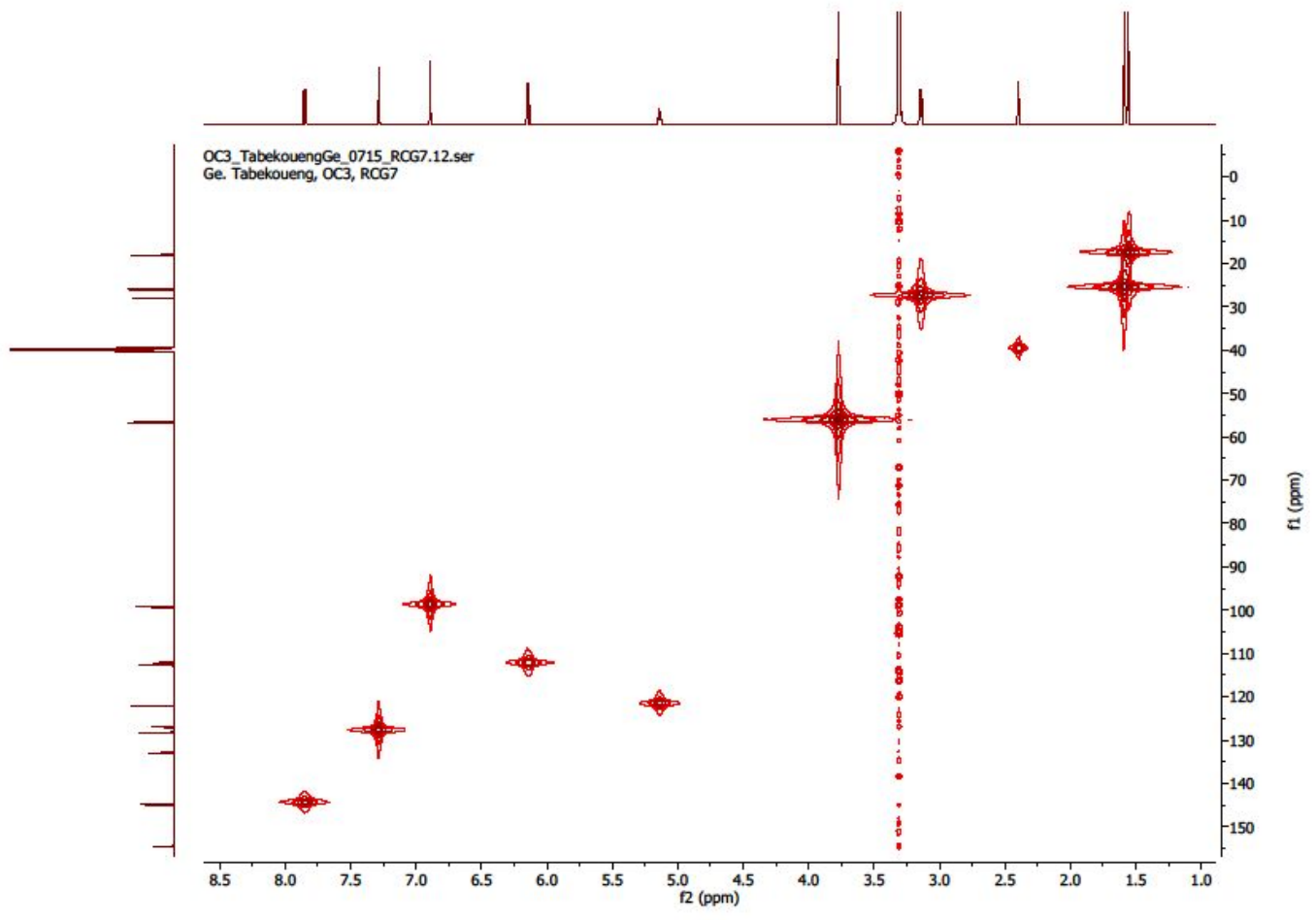

Figure S22: HSQC Spectrum of Suberosin (4) 


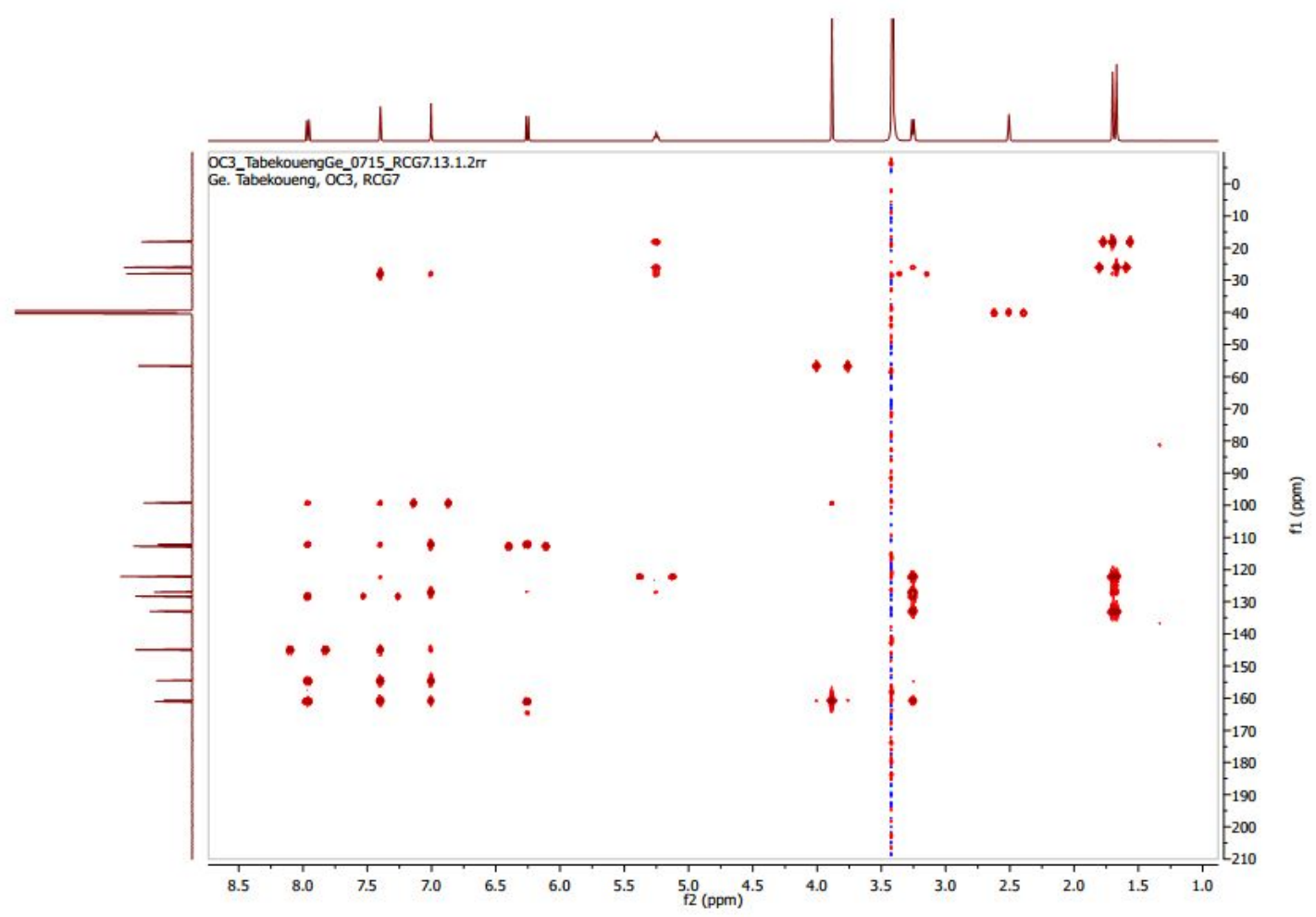

Figure S23: HMBC Spectrum of Suberosin (4)

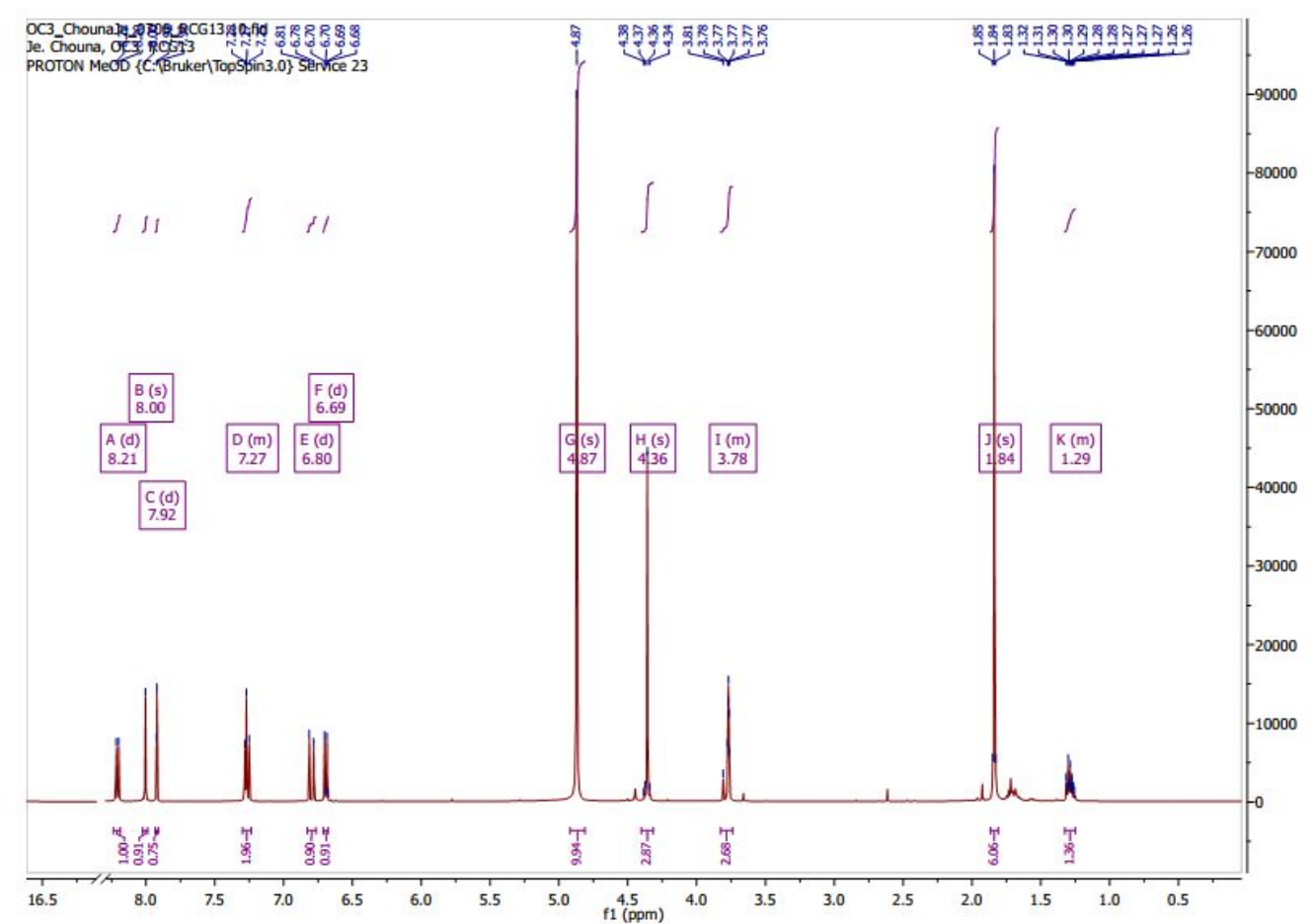

Figure S24: ${ }^{1} \mathrm{H} N \mathrm{NR}$ Spectrum (500 MHz, $\mathrm{CDCl}_{3}$ ) of E-suberenol (5) 


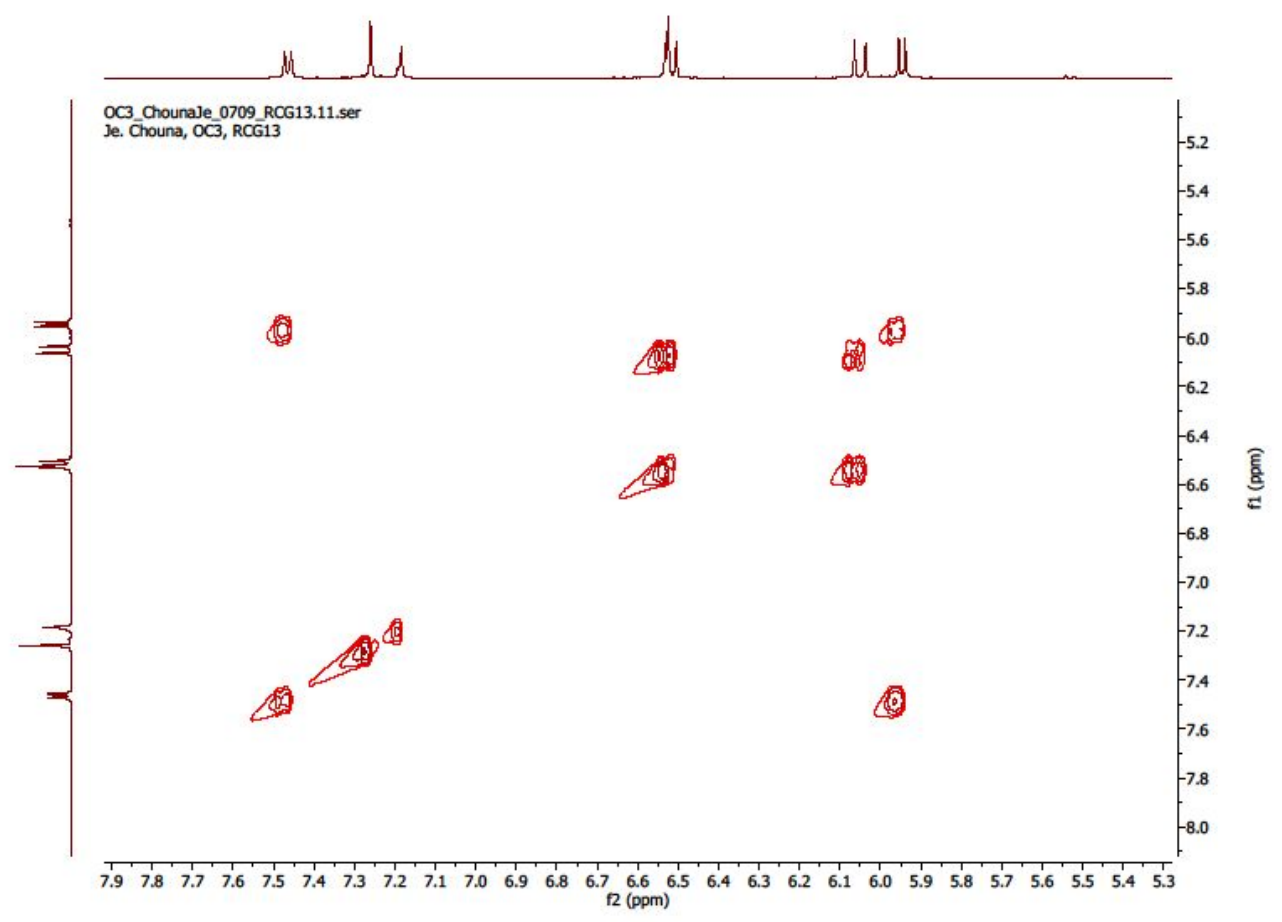

Figure S25: COSY Spectrum of E-suberenol (5)

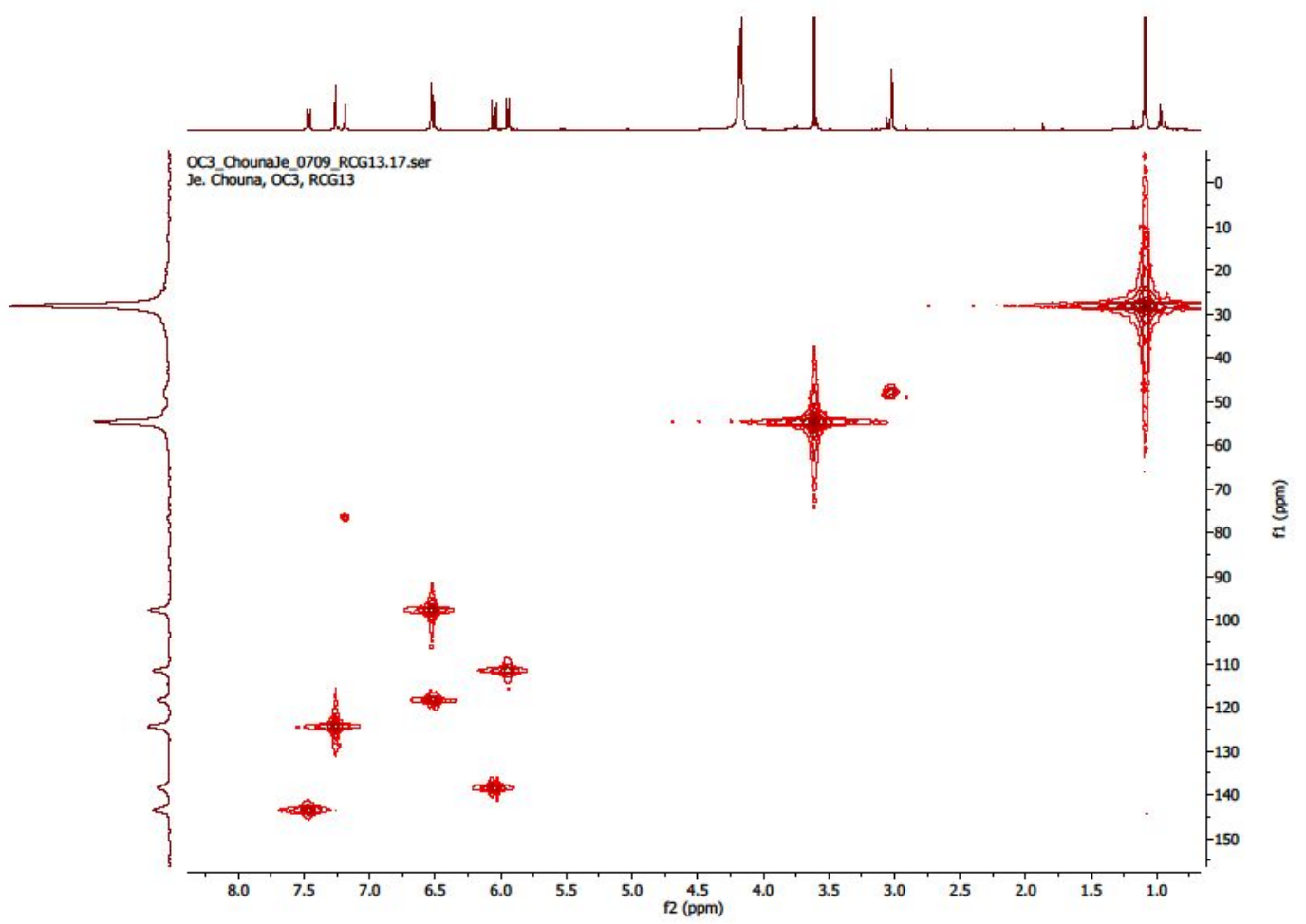

Figure S26: HSQC Spectrum of E-suberenol (5) 


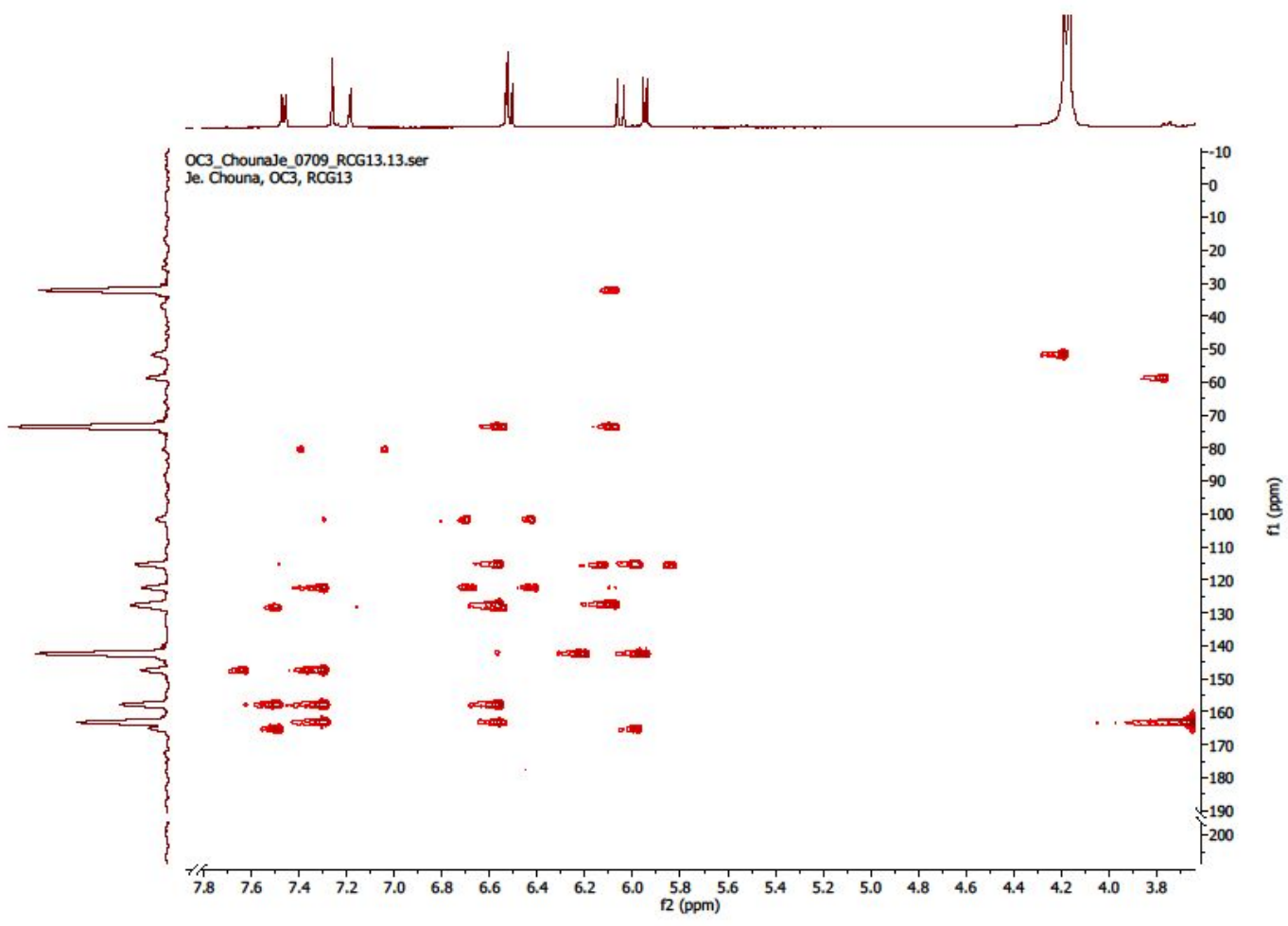

Figure S27: HMBC Spectrum of E-suberenol (5)

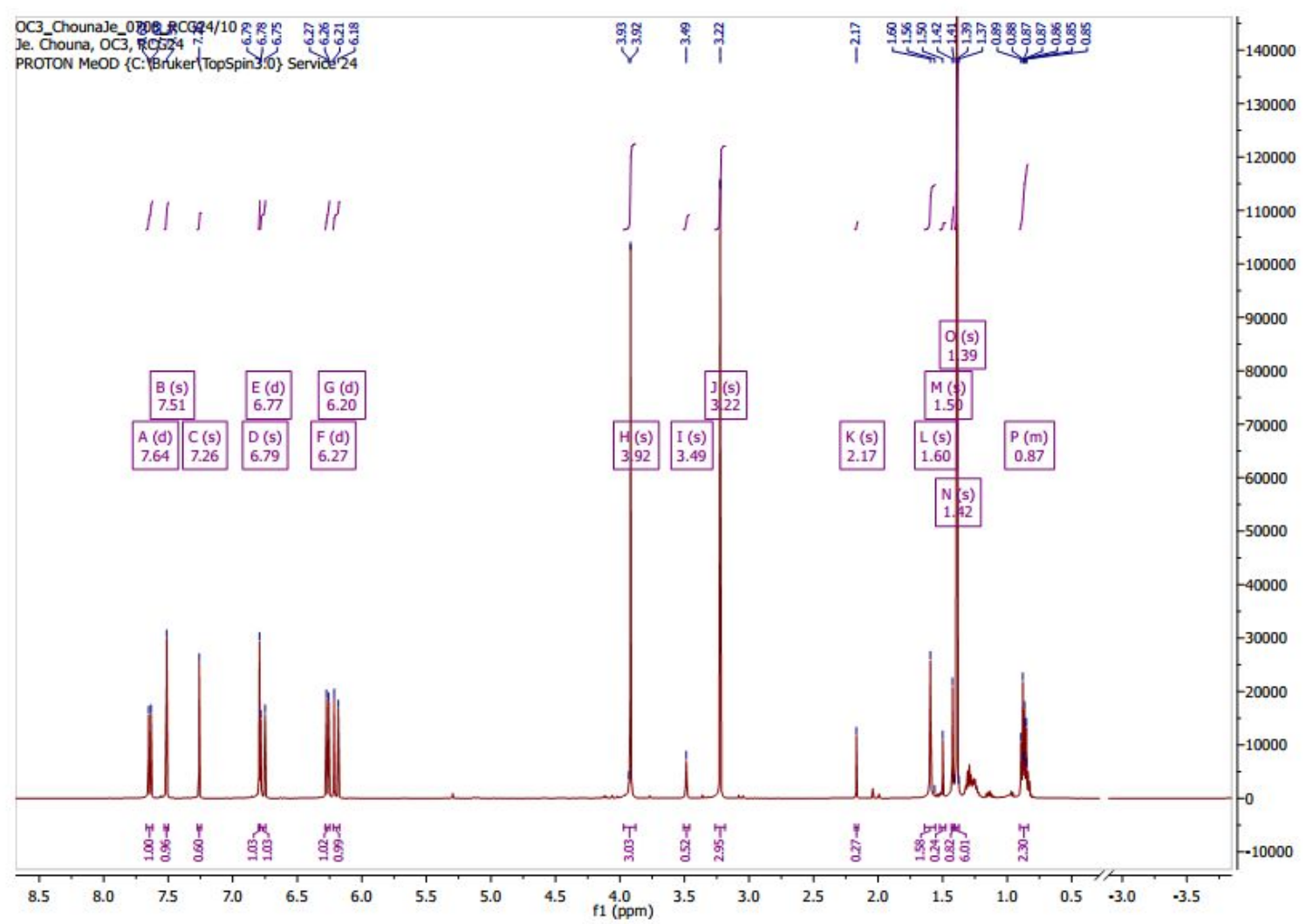

Figure S28: ${ }^{1} \mathrm{H}$ NMR Spectrum (500 MHz, $\mathrm{CD}_{3} \mathrm{OD}$ ) of E-methoxysuberenol (6) 


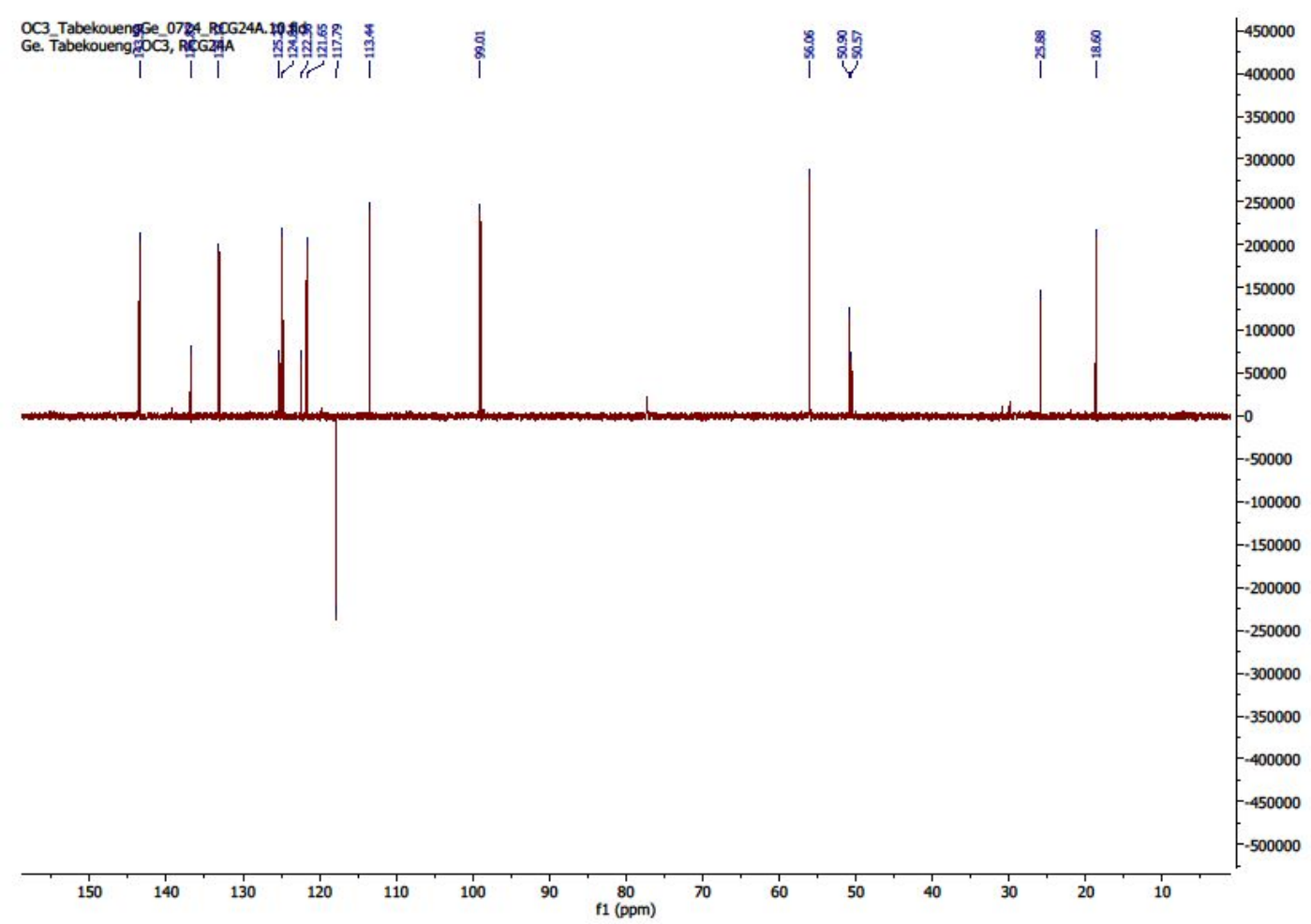

Figure S29: 135-DEPT Spectrum (125 MHz, $\left.C D_{3} O D\right)$ Spectrum of E-methoxysuberenol (6)

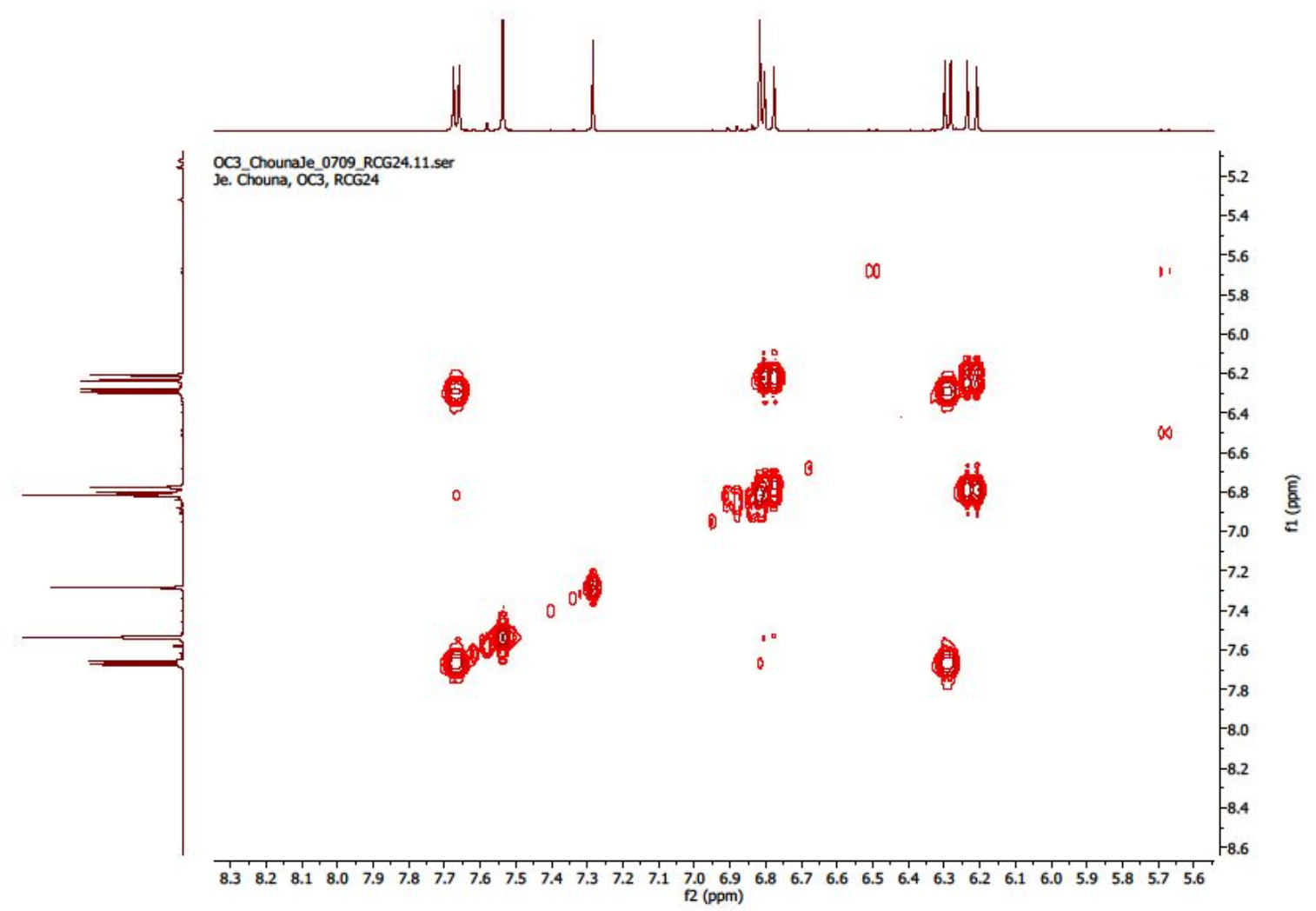

Figure S30: COSY Spectrum of E-methoxysuberenol (6) 


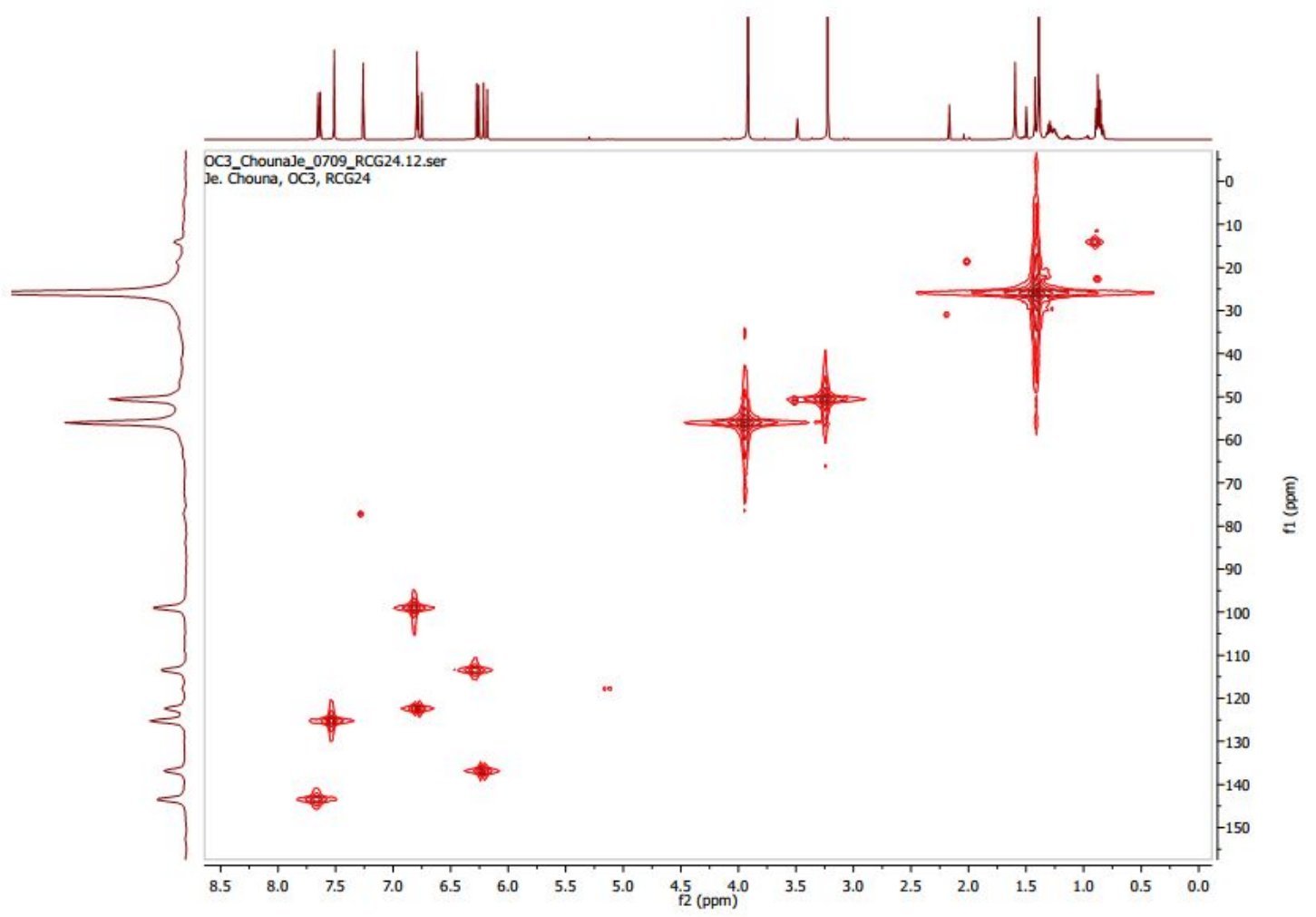

Figure S31: HSQC Spectrum of E-methoxysuberenol (6)

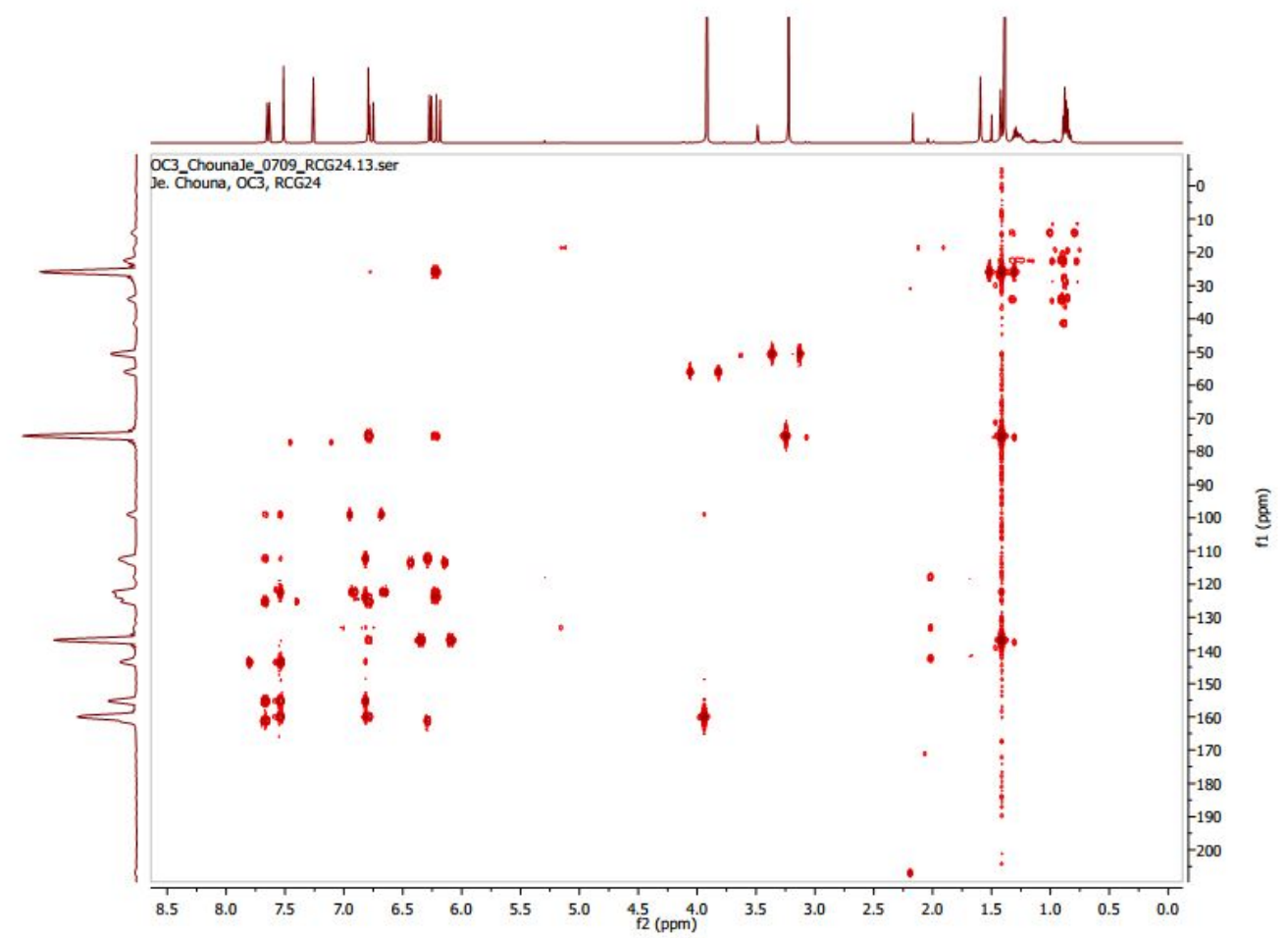

Figure S32: HMBC Spectrum of E-methoxysuberenol (6) 


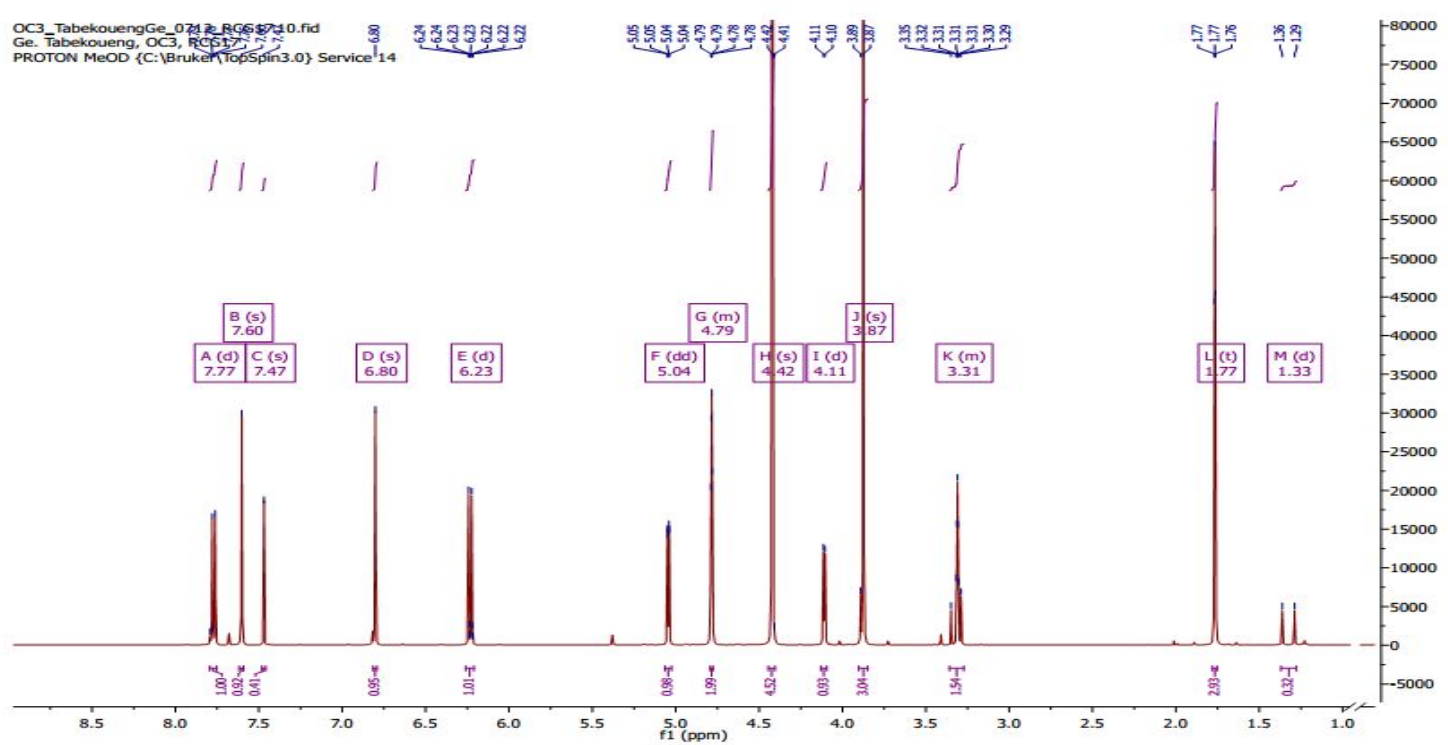

Figure S33: ${ }^{1} \mathrm{H}$ NMR Spectrum (500 MHz, $\left.C D_{3} O D\right)$ of Thamnosmonin (7)

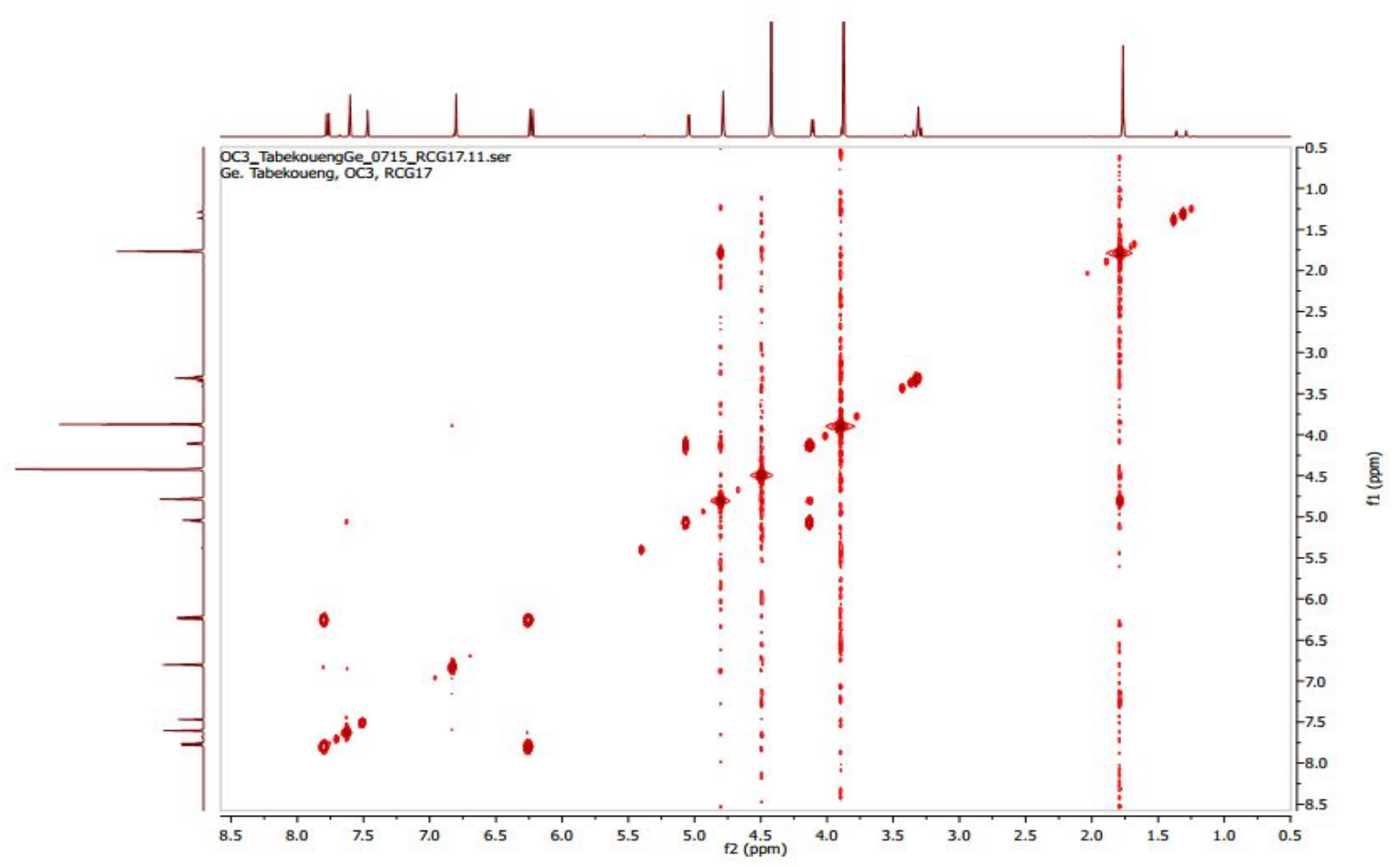

Figure S34: COSY Spectrum of compound (7) (Thamnosmonin) 


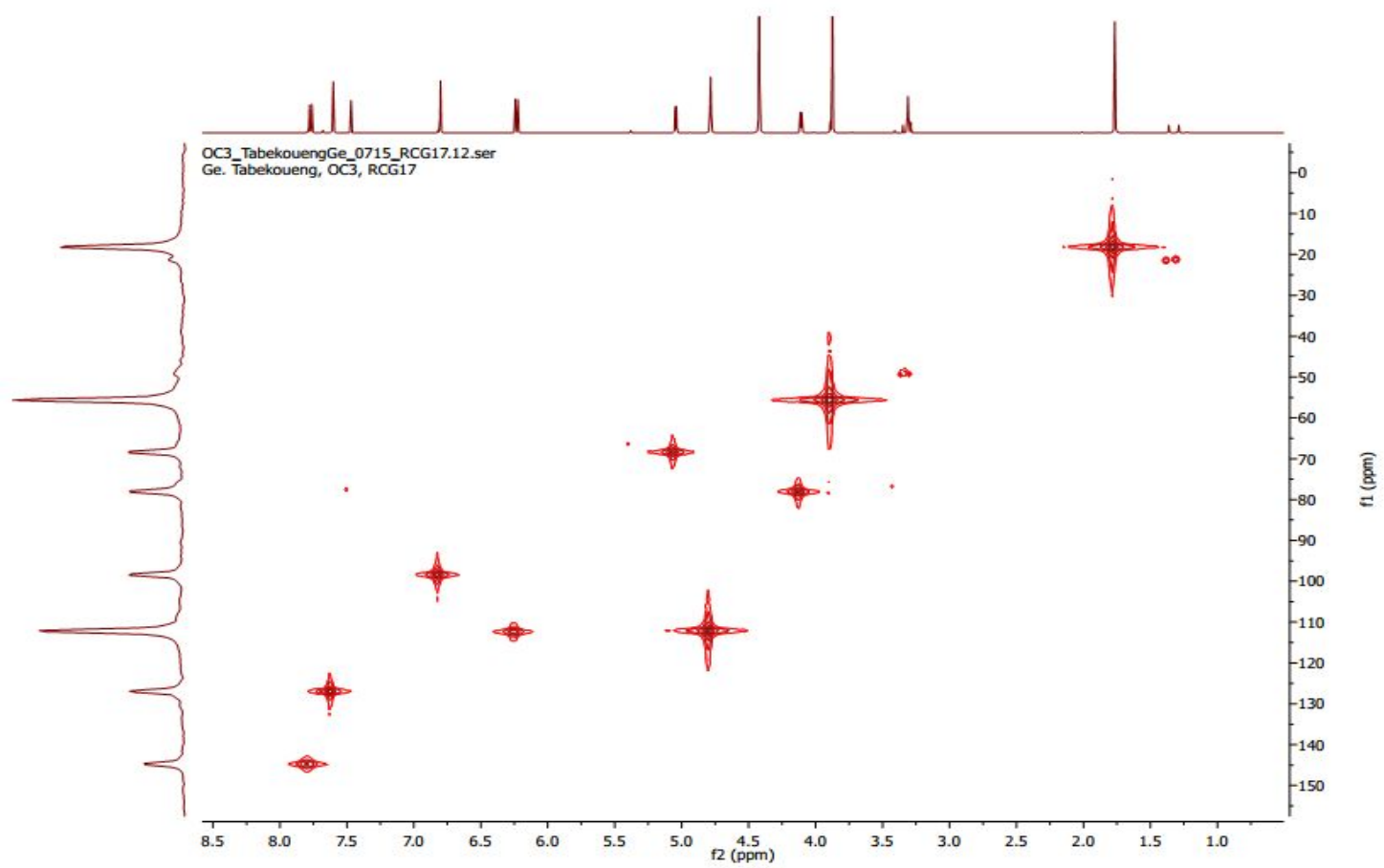

Figure S35: HSQC Spectrum of Thamnosmonin (7)

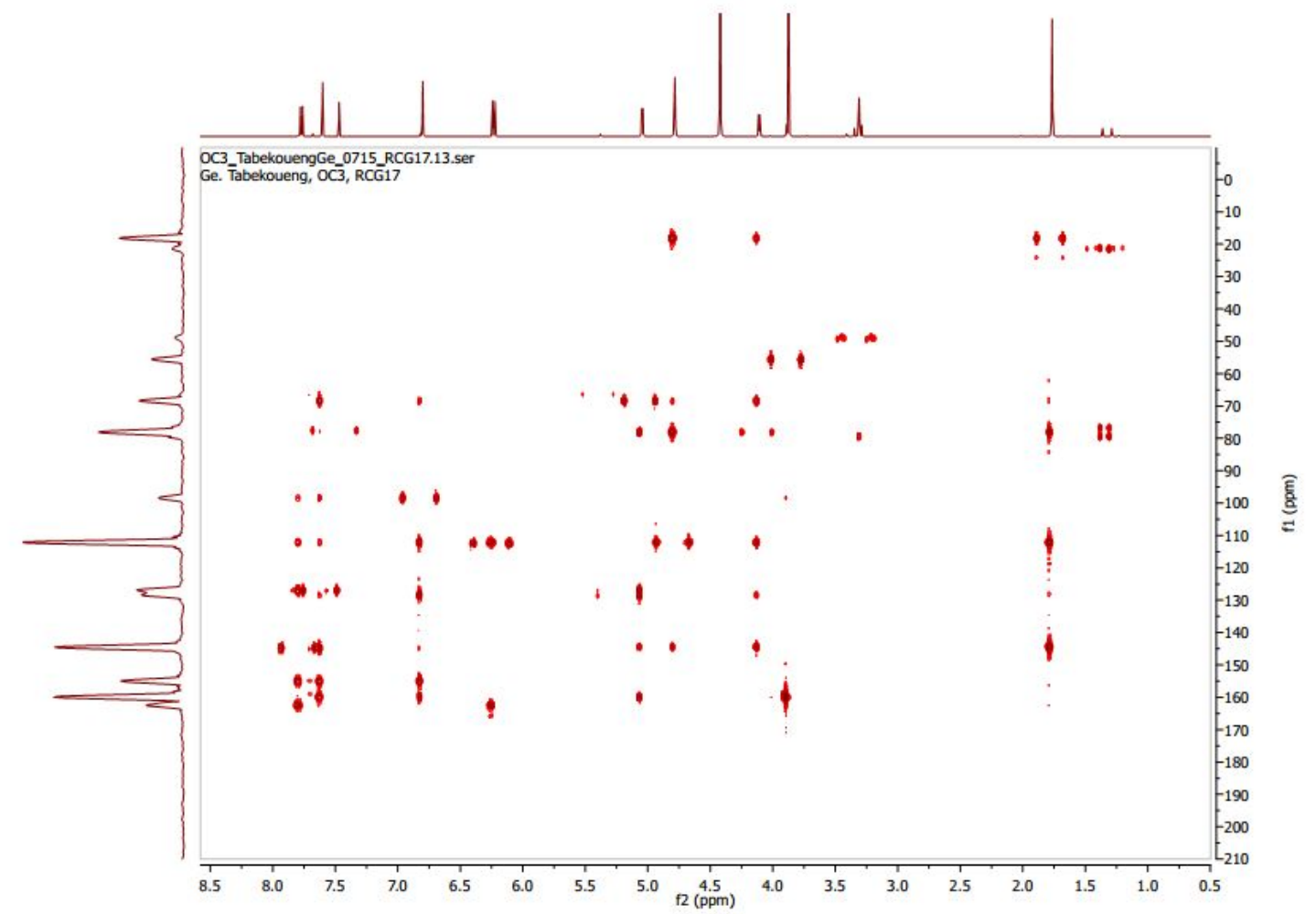

Figure S36: HMBC Spectrum of Thamnosmonin (7) 


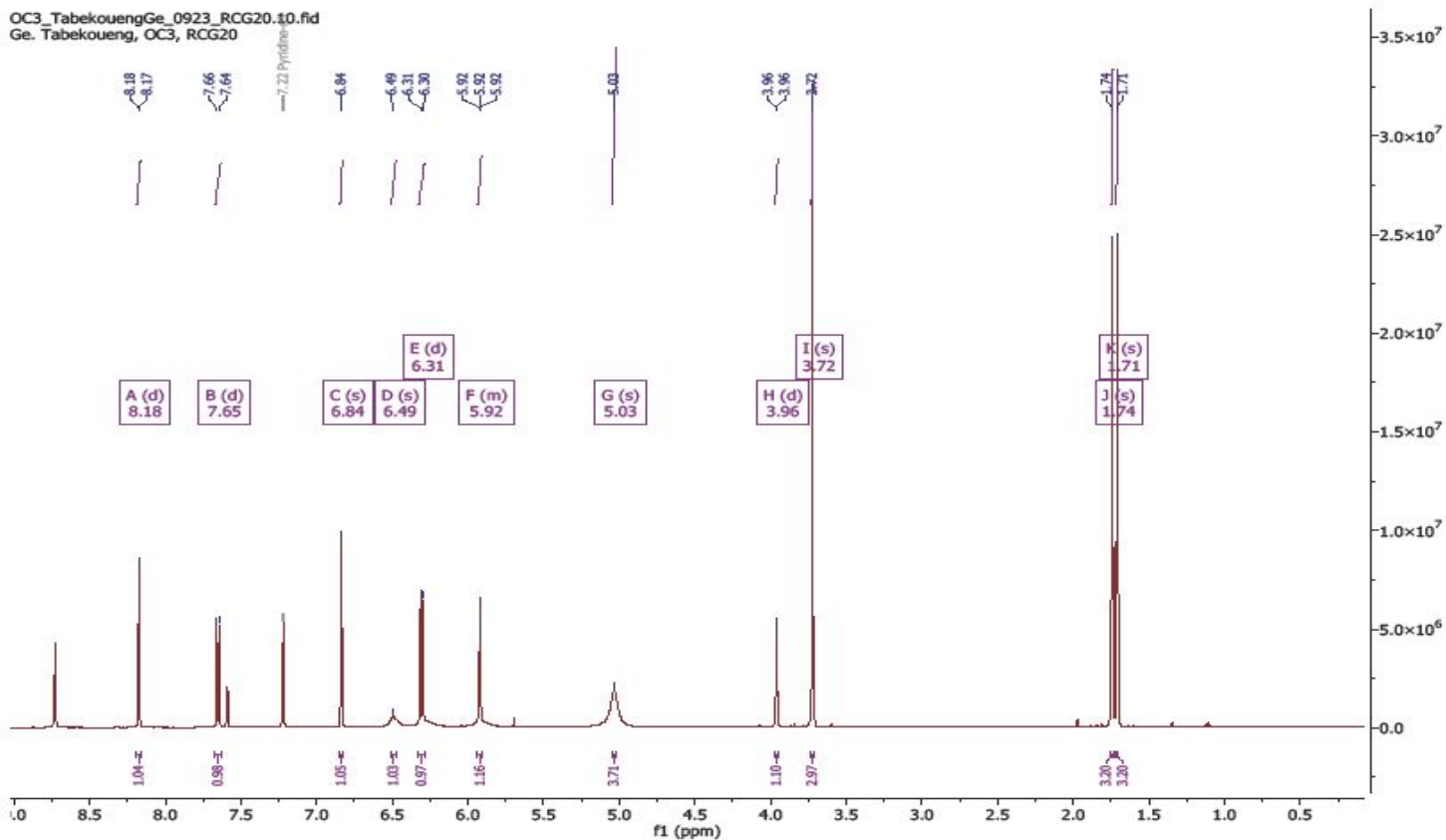

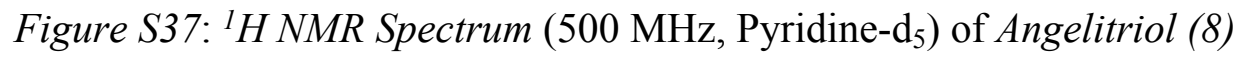

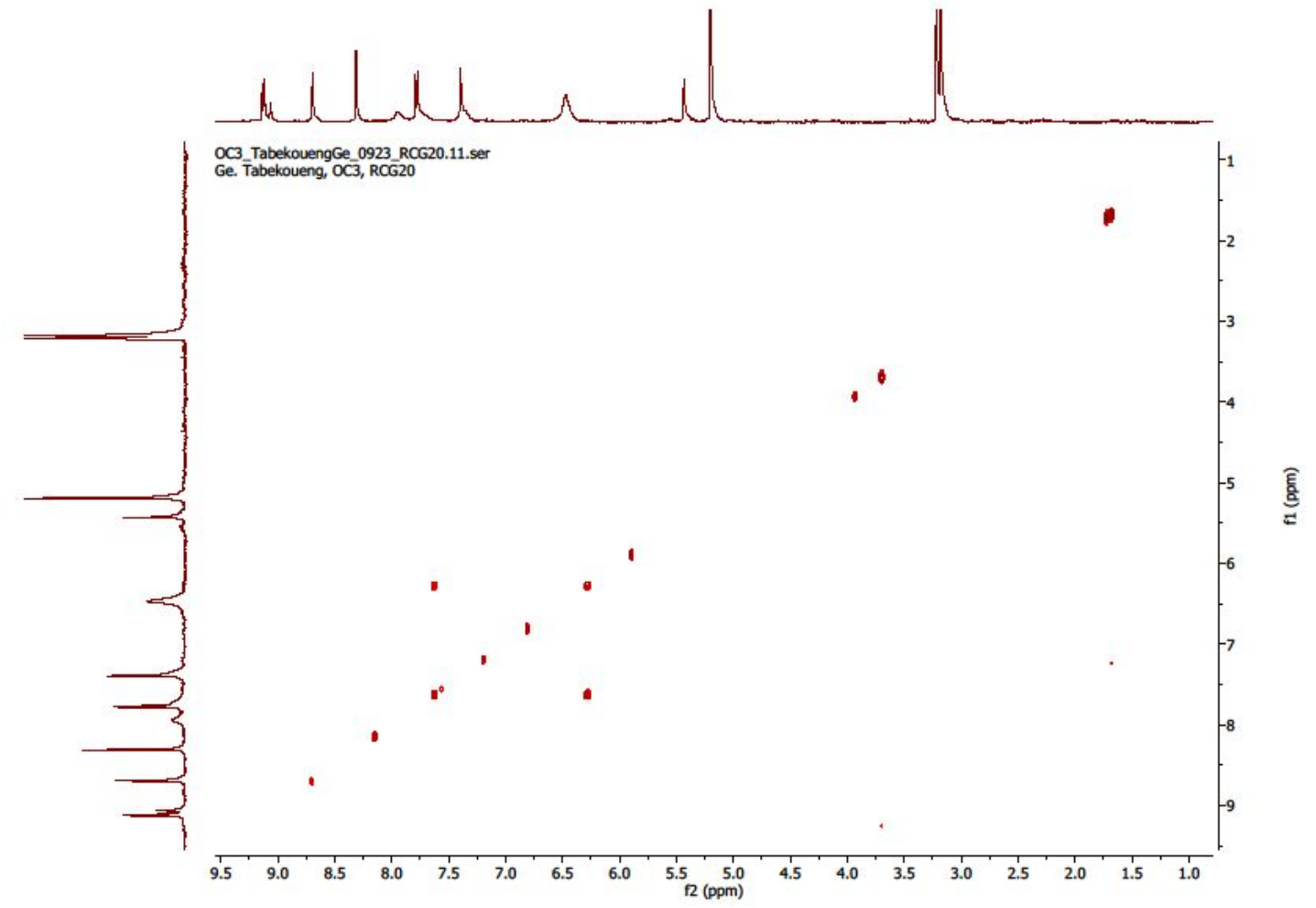

Figure S38: HMBC Spectrum of Angelitriol (8) 


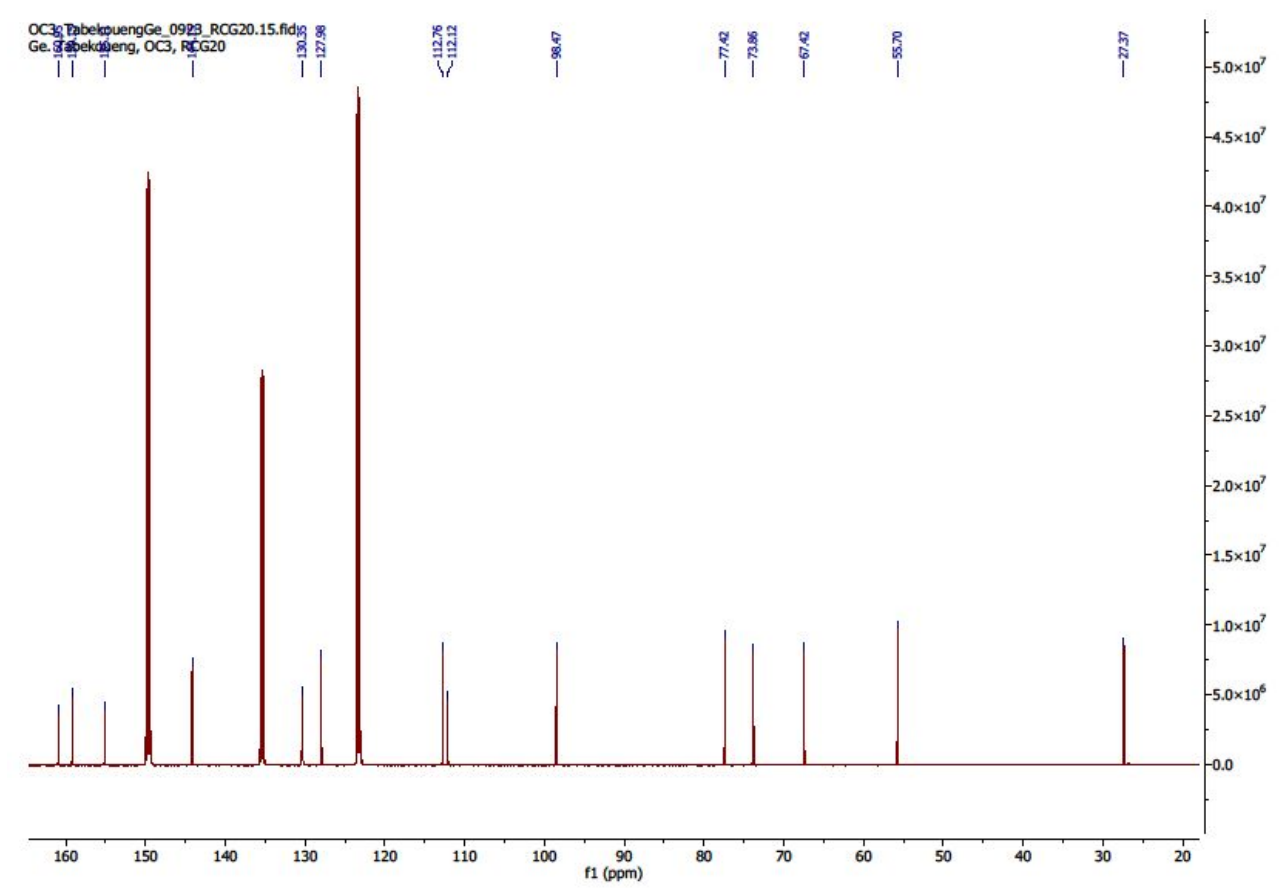

Figure S39: ${ }^{13}$ C NMR Spectrum (125 MHz, Pyridine-d ( $_{5}$ of Angelitriol (8)

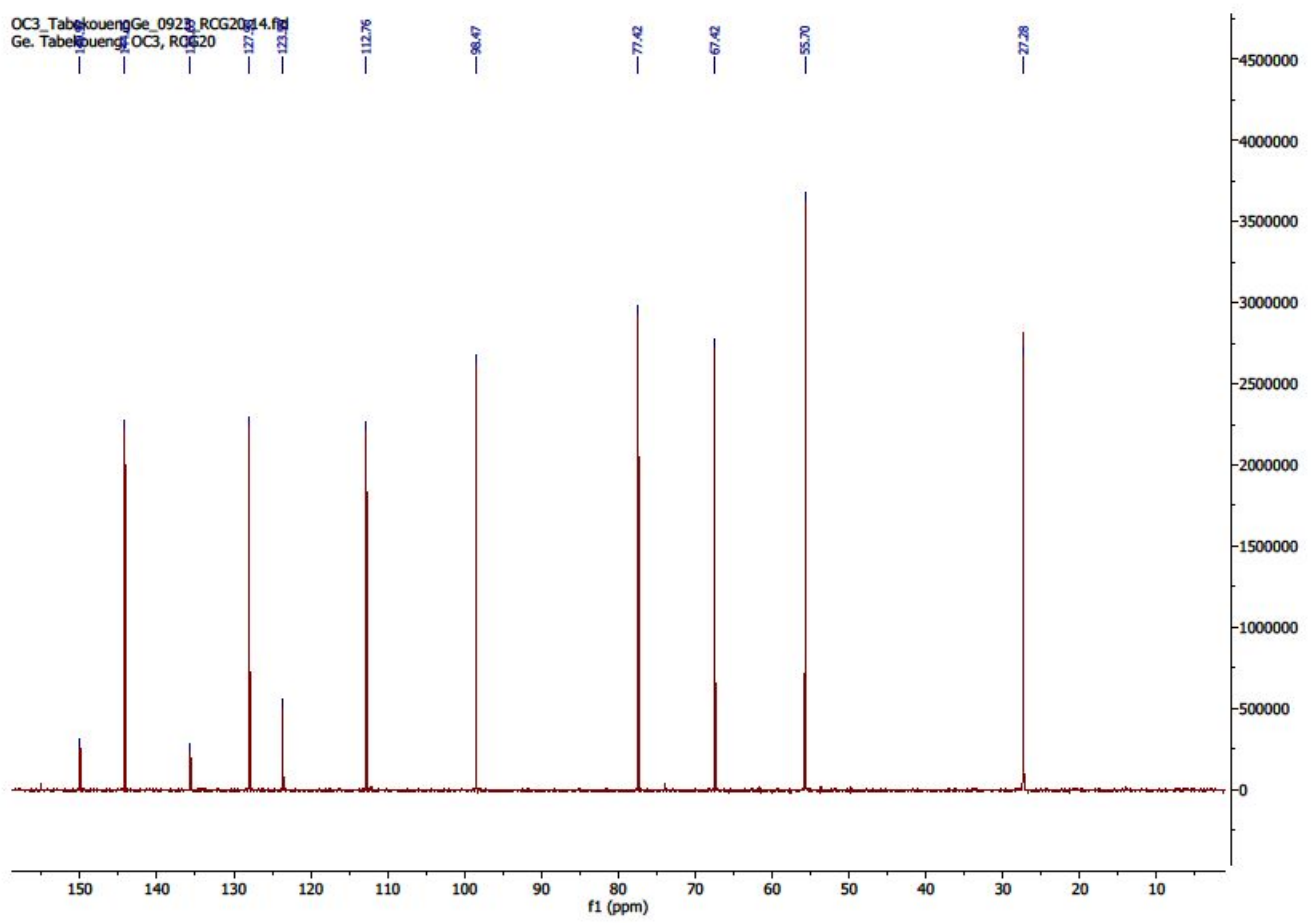

Figure S40: 135-DEPT Spectrum (125 MHz, Pyridine-d 5 ) of Angelitriol (8) 


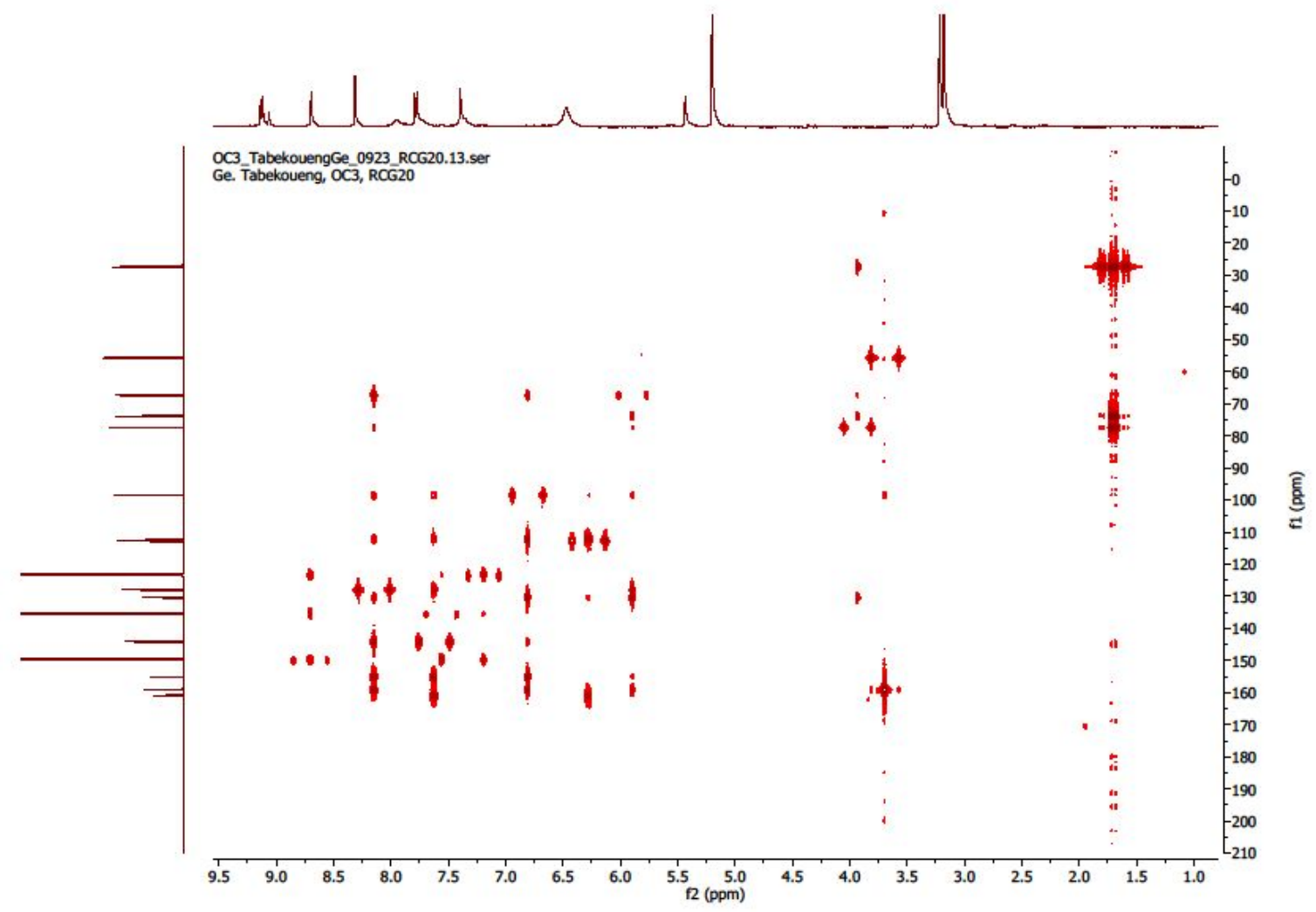

Figure S41: HMBC Spectrum of Angelitriol (8)

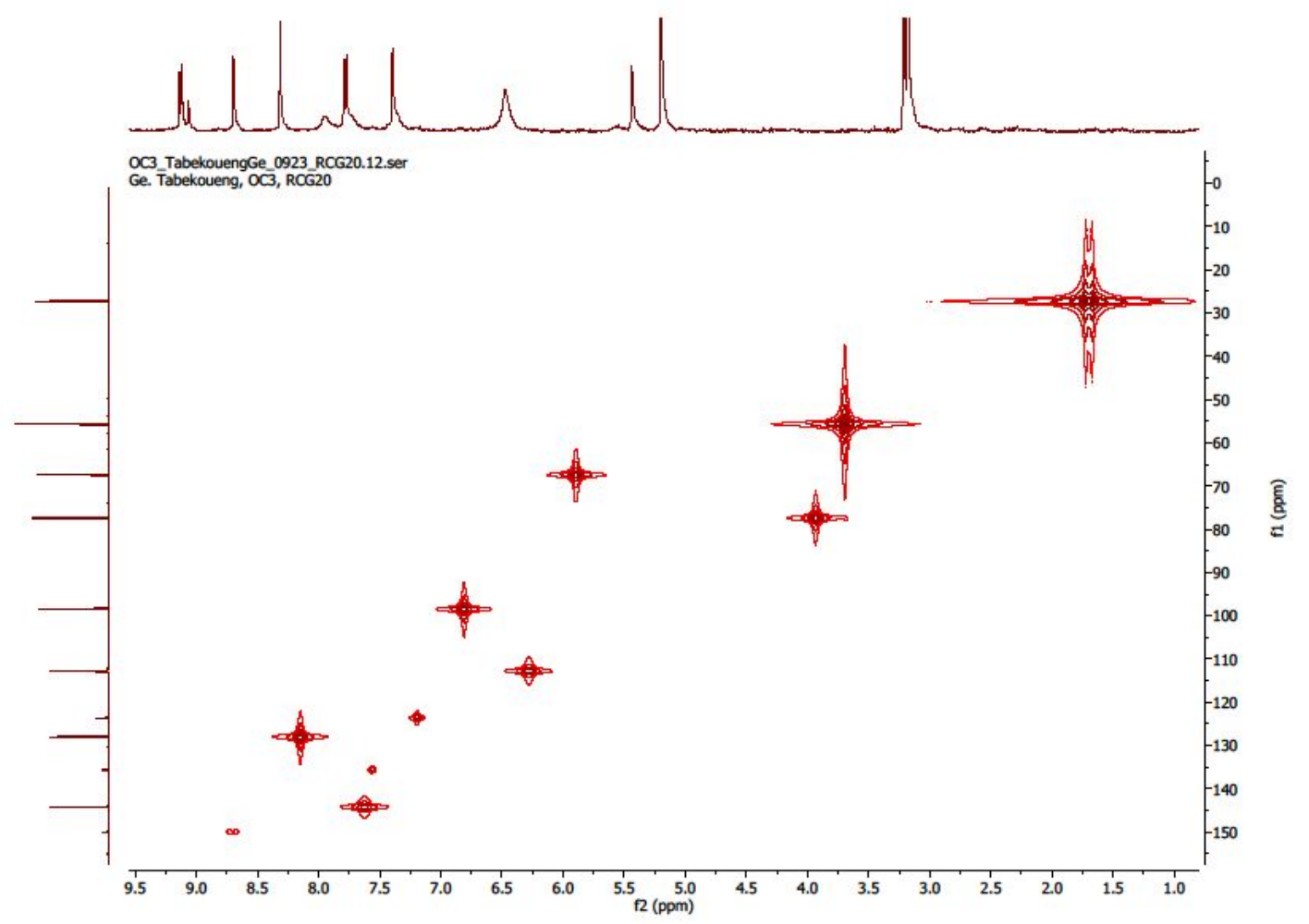

Figure S42: HSQC Spectrum of Angelitriol (8) 


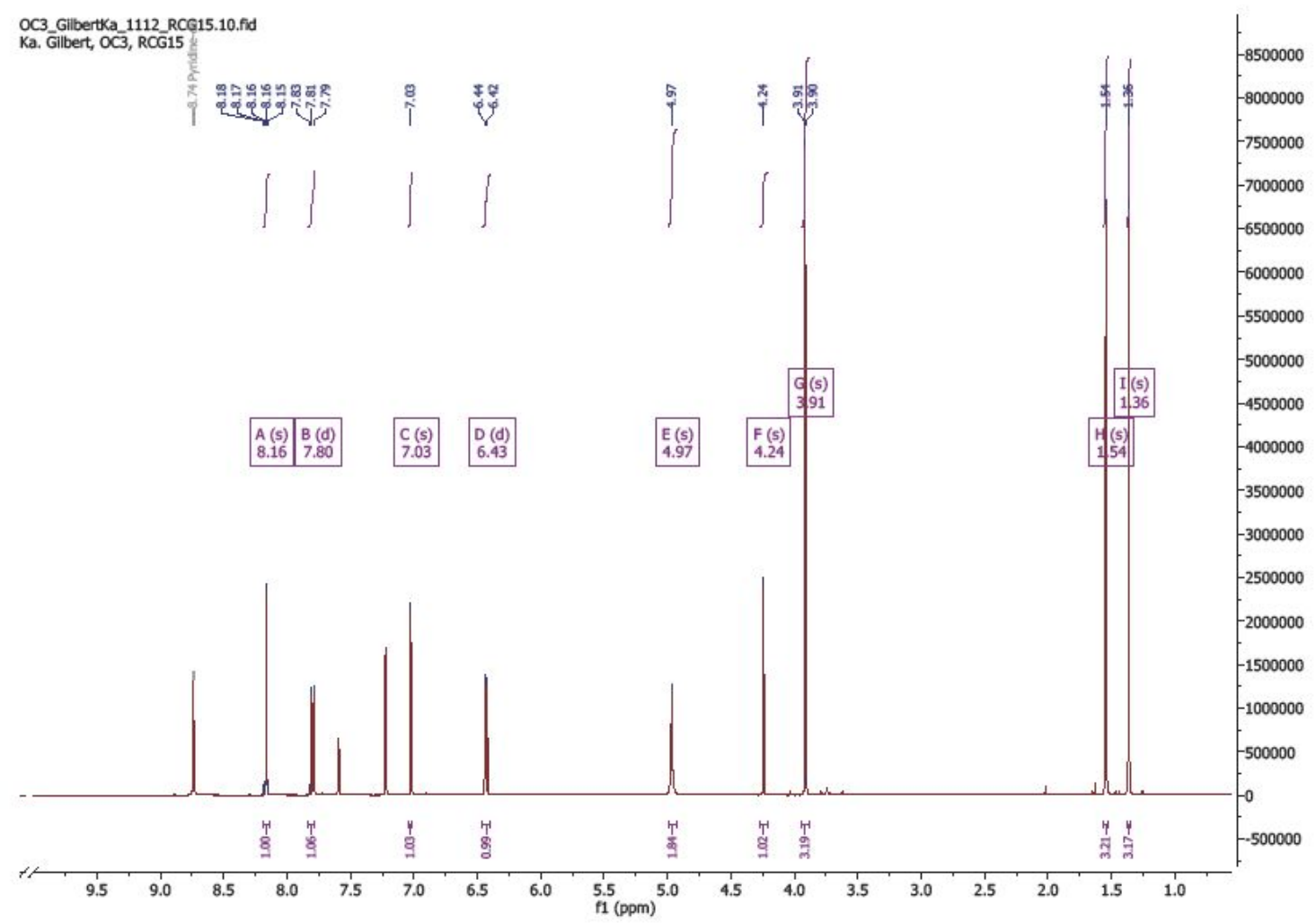

Figure S43: ${ }^{1}$ H NMR Spectrum (500 MHz, Pyridine- $d_{5}$ ) of Hopey-hopin (9)

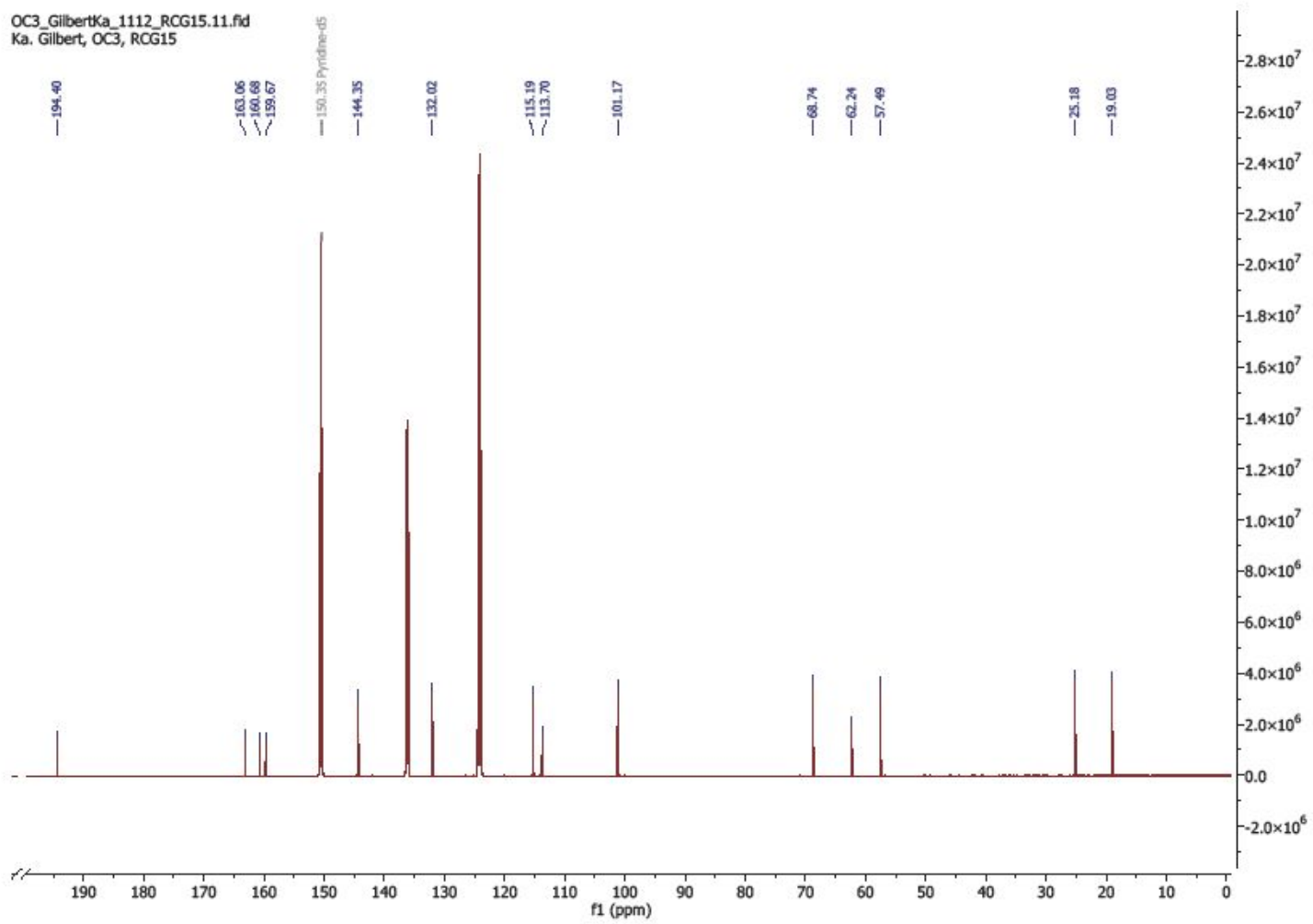

Figure S44: ${ }^{13} \mathrm{C}$ NMR Spectrum (125 MHz, Pyridine-d $\mathrm{d}_{5}$ ) of Hopey-hopin (9) 


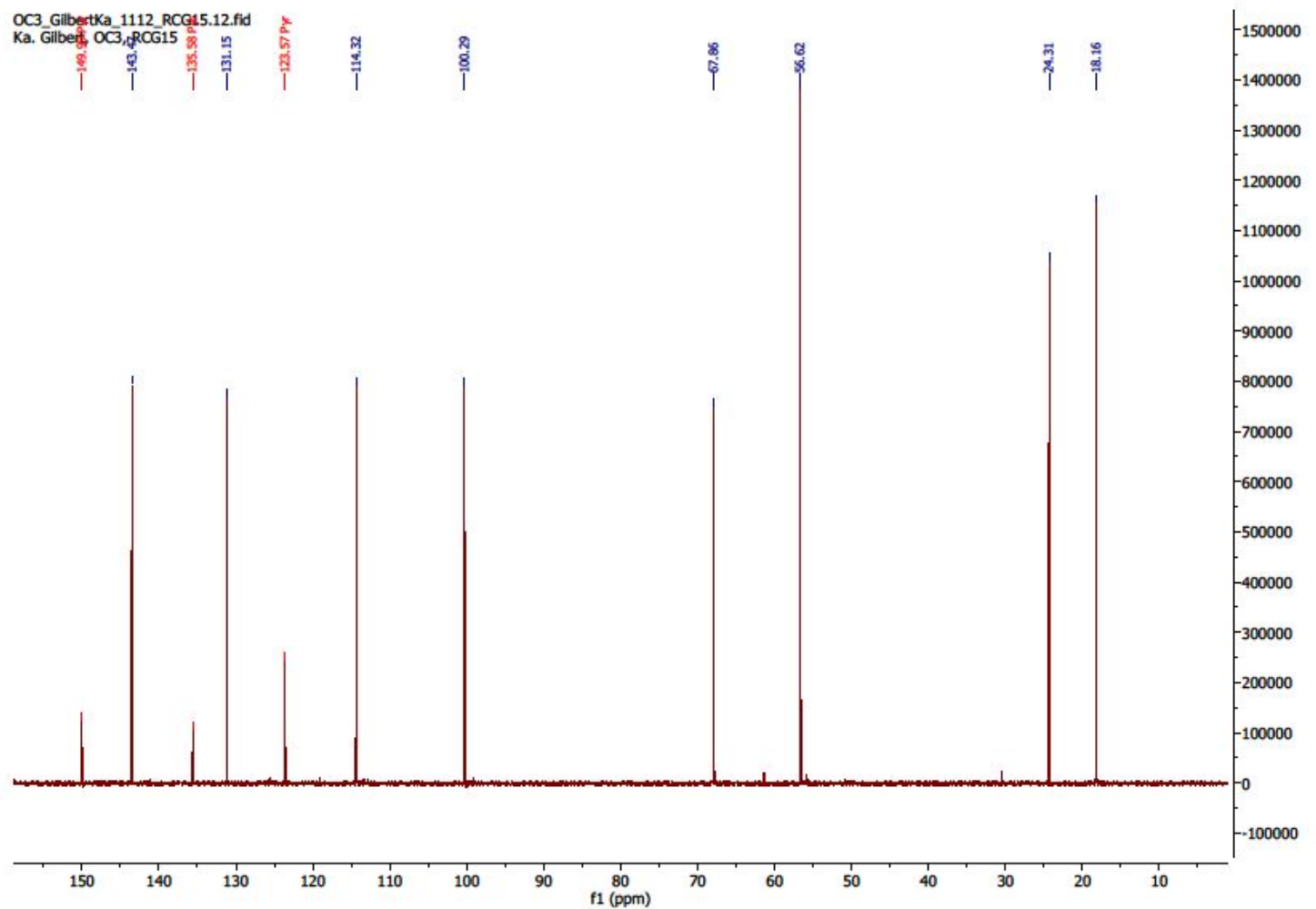

Figure S45: 135-DEPT Spectrum (125 MHz, Pyridine-d s $_{\text {) }}$ of Hopey-hopin (9)

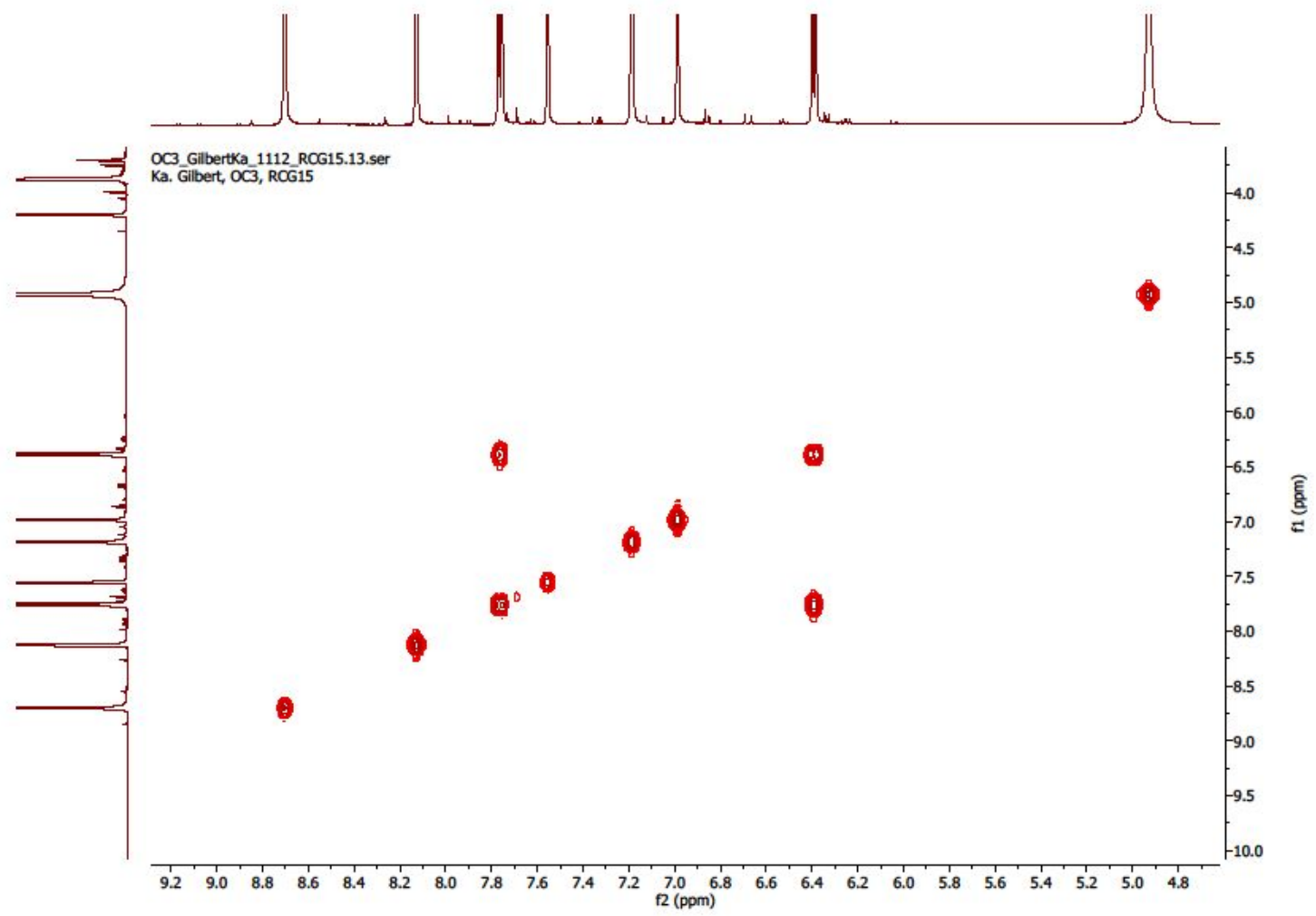

Figure S46: COSY Spectrum of Hopey-hopin (8) 


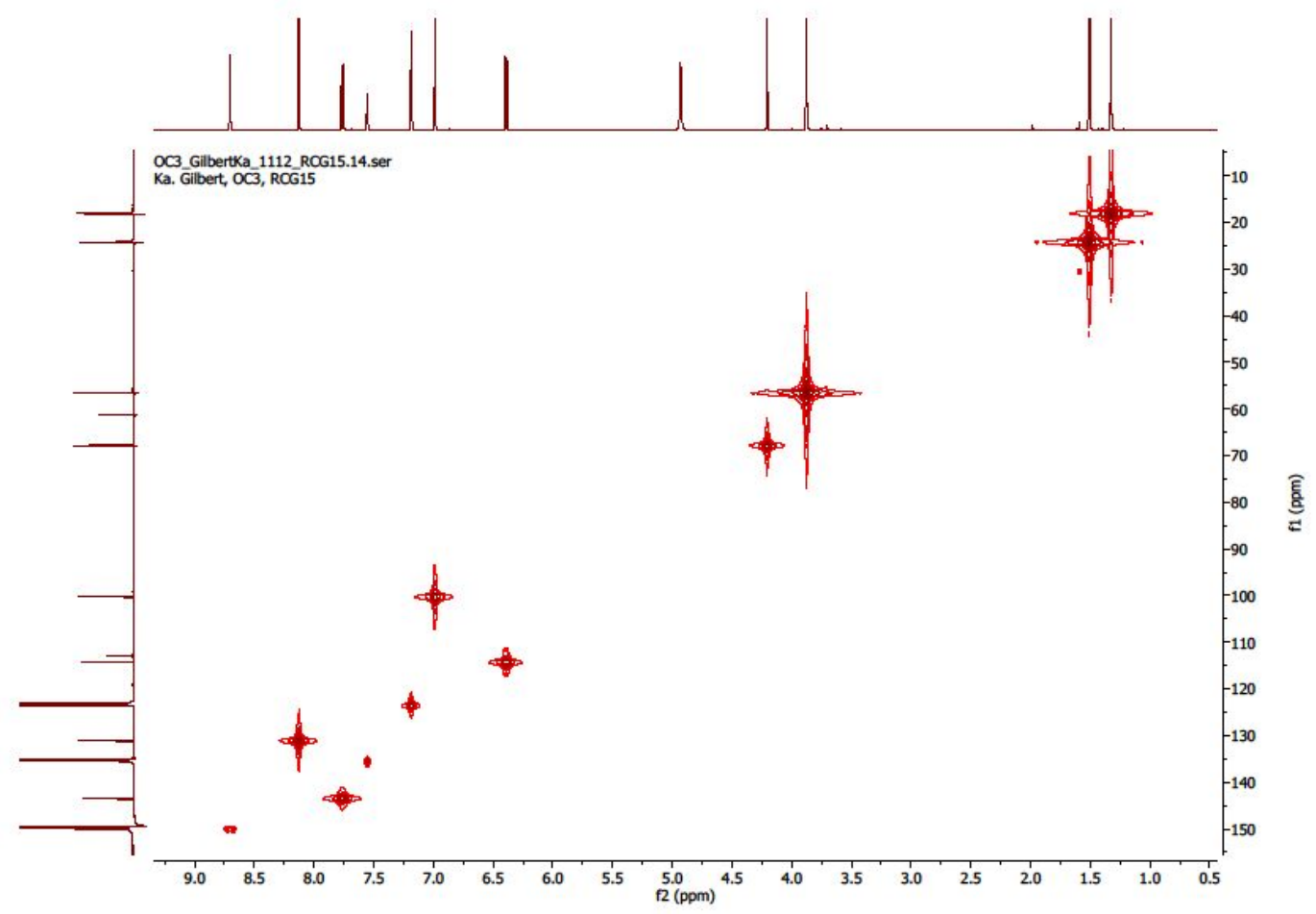

Figure S47: HSQC Spectrum of Hopey-hopin (9)

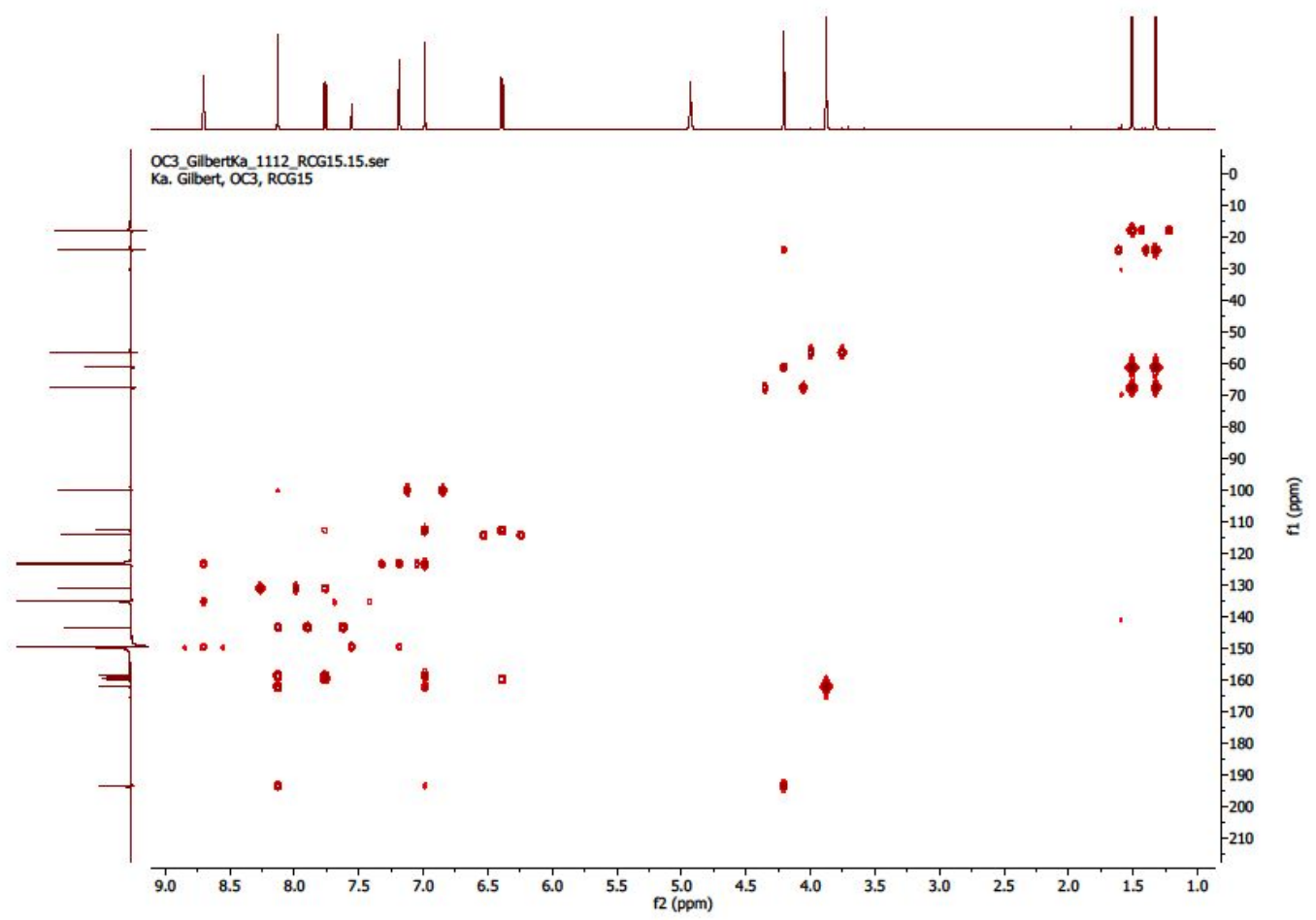

Figure S48: HMBC Spectrum of Hopey-hopin (9) 


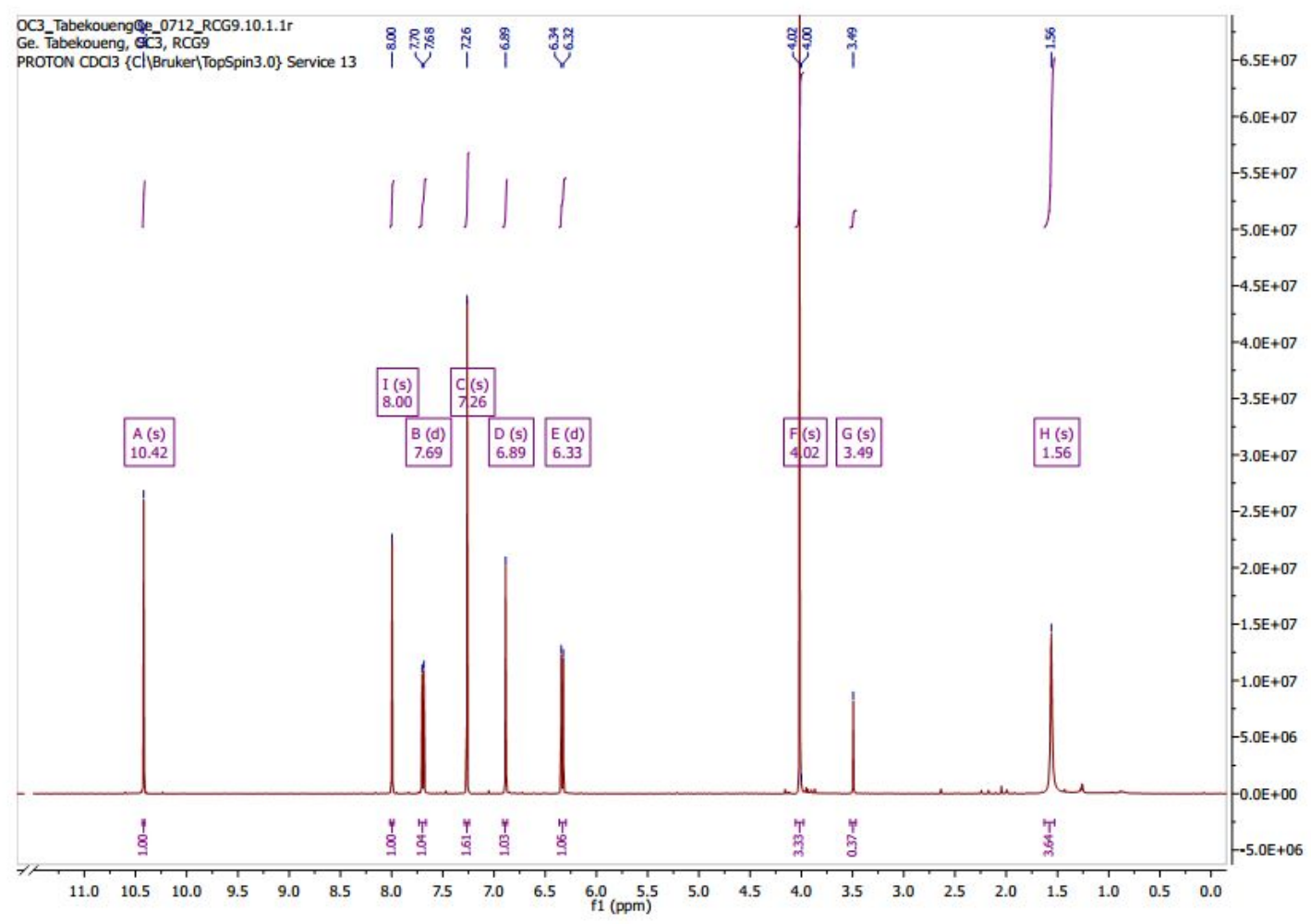

Figure S49: ${ }^{1} \mathrm{H}$ NMR Spectrum(500 MHz, $\left.\mathrm{CDCl}_{3}\right)$ of Formlylumbeliferone (10)

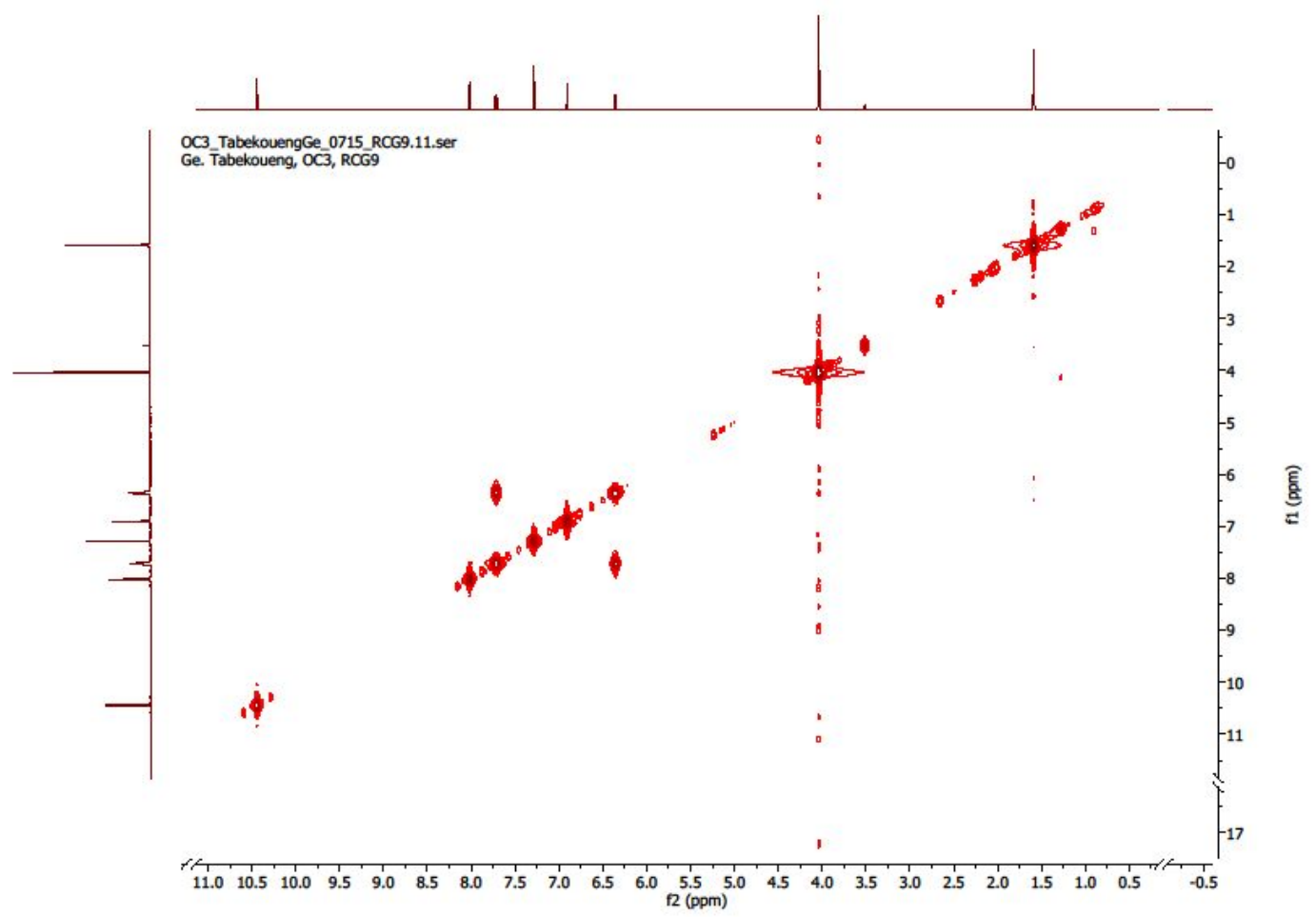

Figure S50: HSQC Spectrum of Formlylumbeliferone (10) 


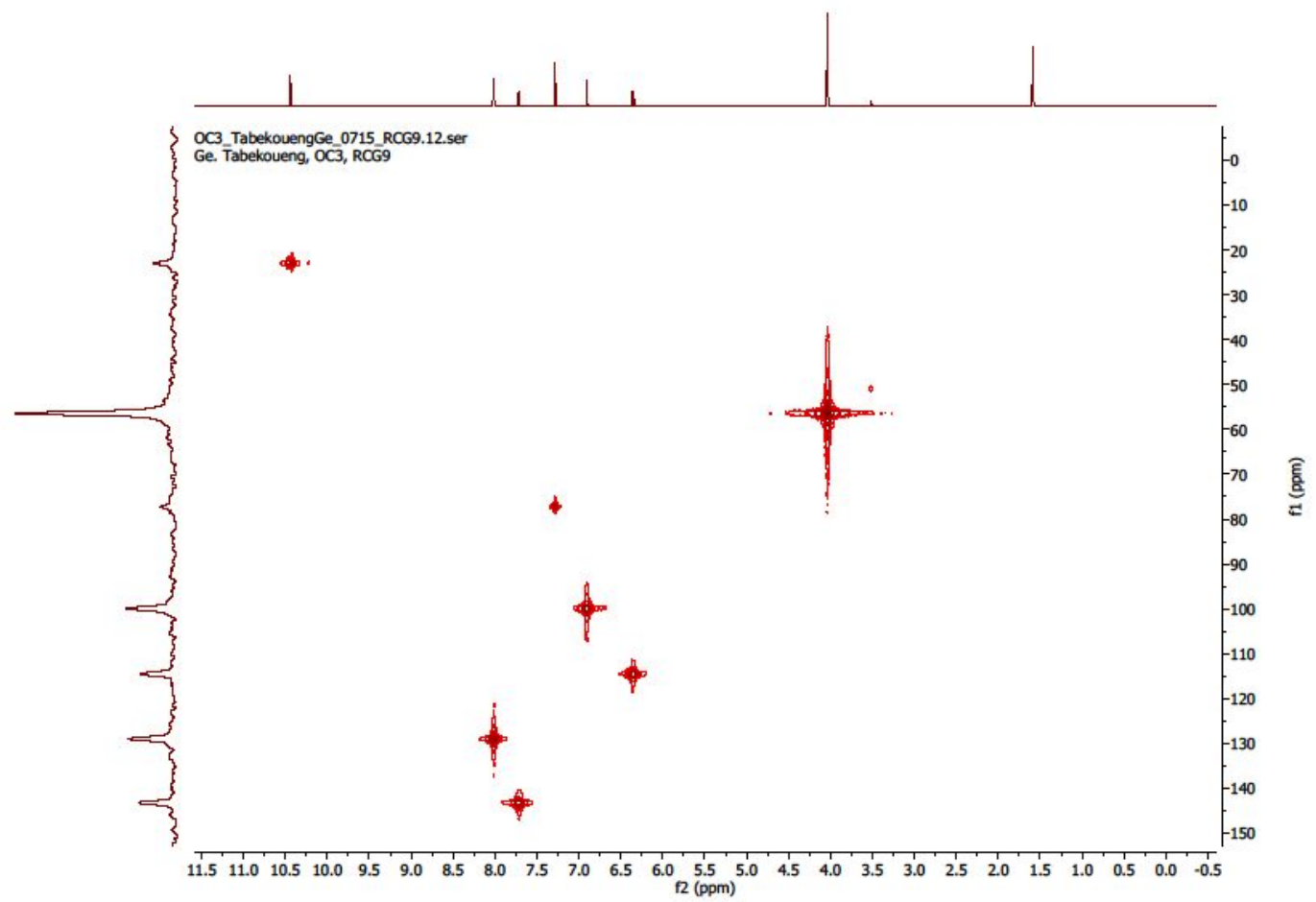

Figure S51: HSQC Spectrum of Formlylumbeliferone (10)

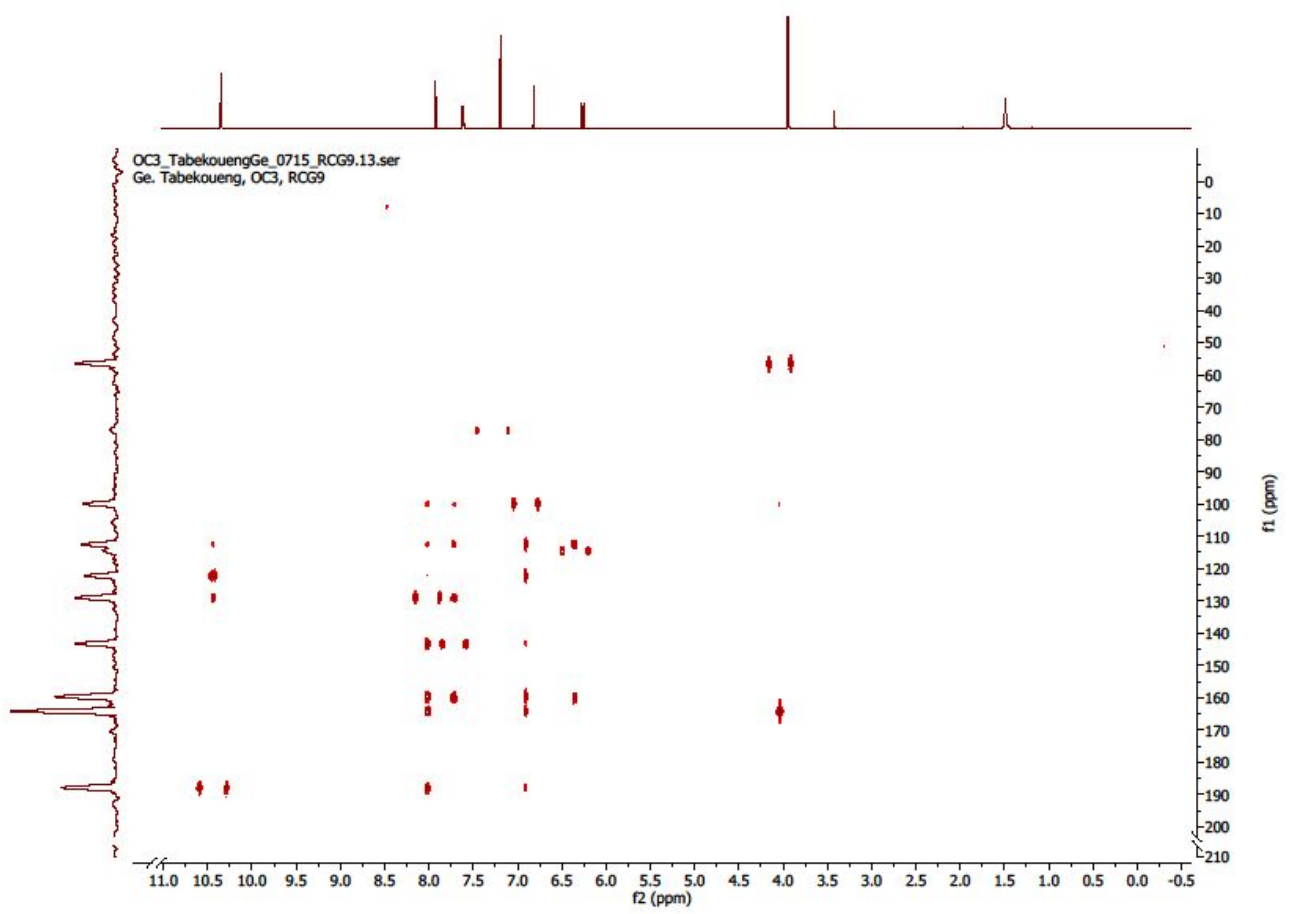

Figure S52: HMBC Spectrum of Formlylumbeliferone (10) 


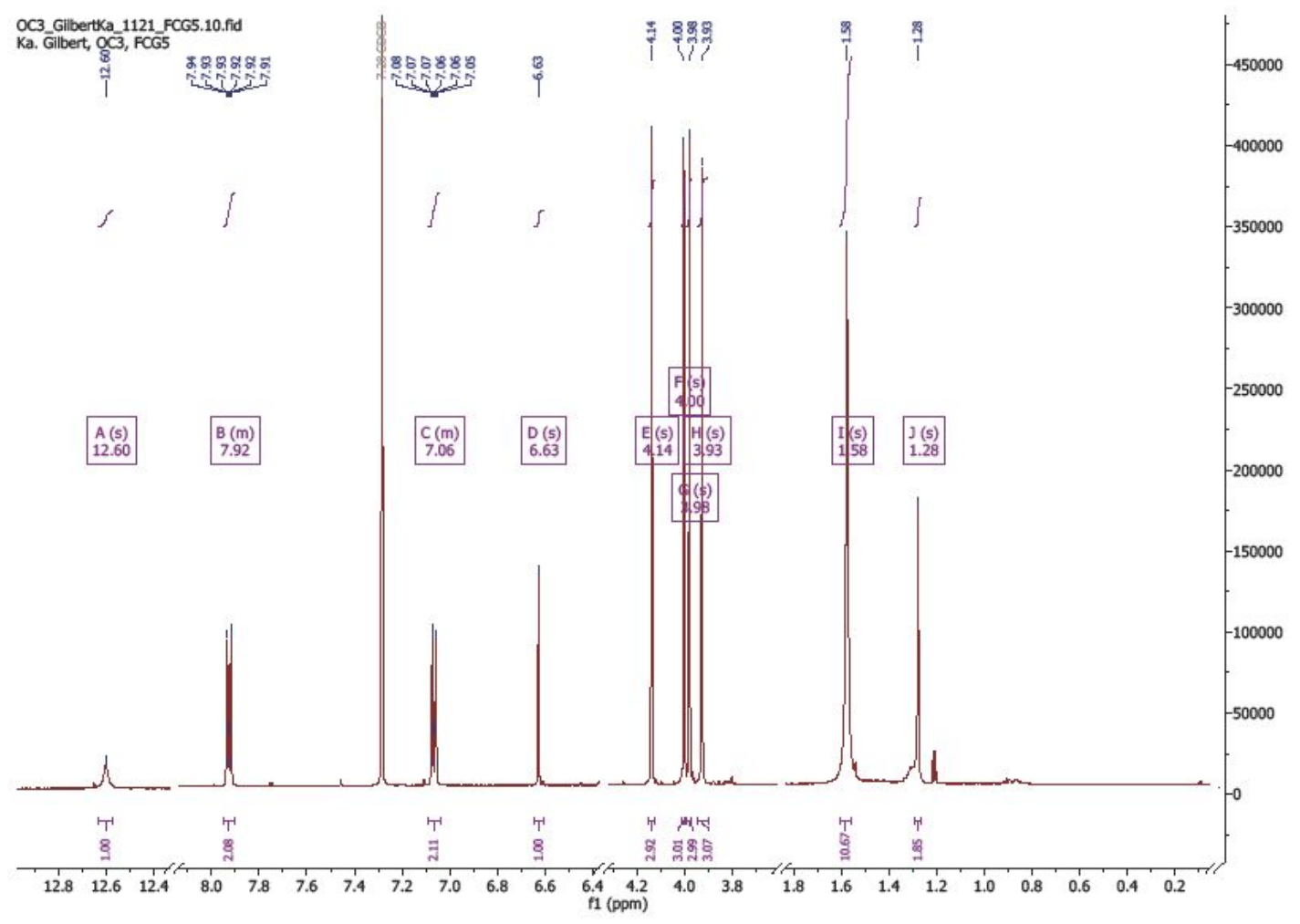

Figure S53: ${ }^{1} \mathrm{H}$ NMR Spectrum (500 MHz, $\mathrm{CDCl}_{3}$ ) of 5-OH-6,7,8,4'-Tetrametoxyflavone (11)

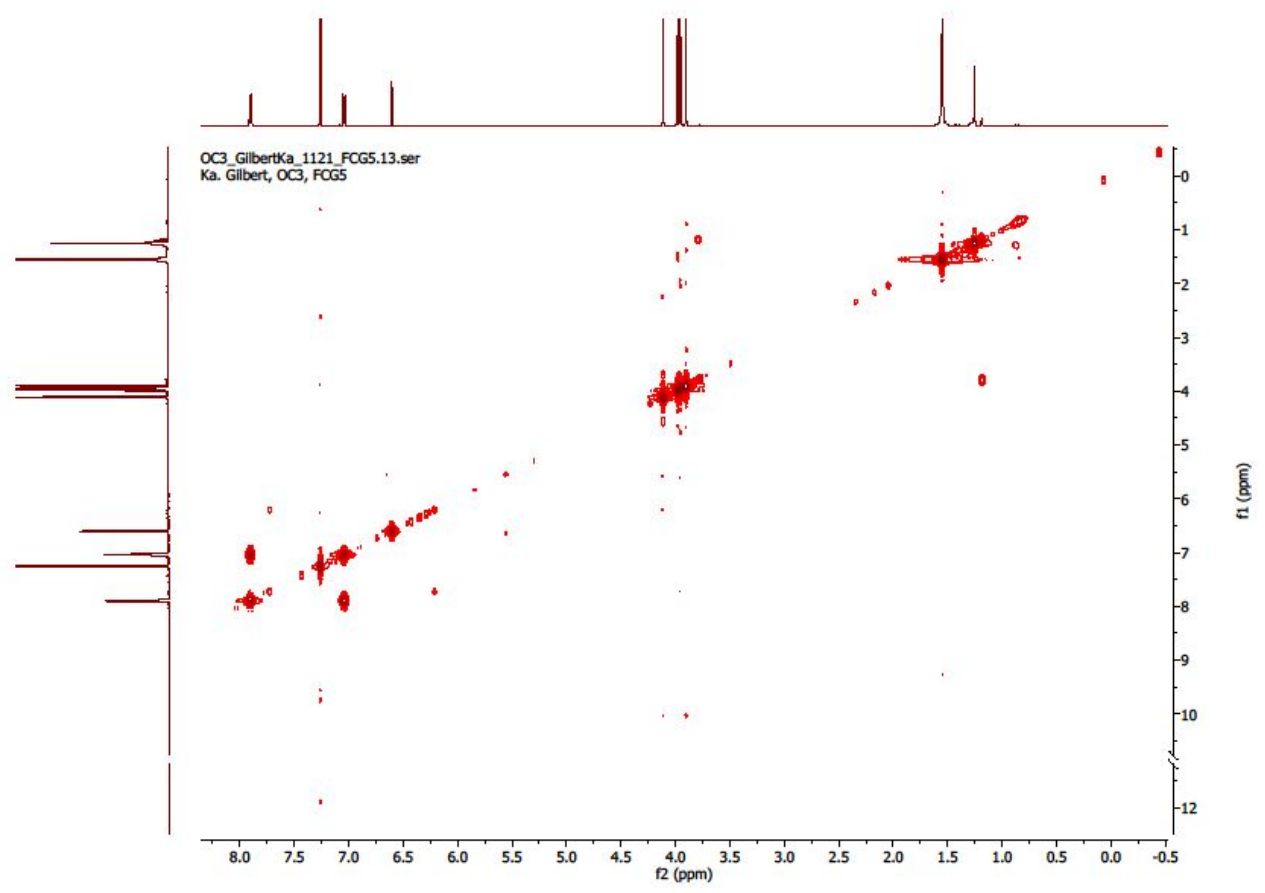

Figure S54: COSY Spectrum of 5-OH-6, 7,8,4'-Tetrametoxyflavone (11) 


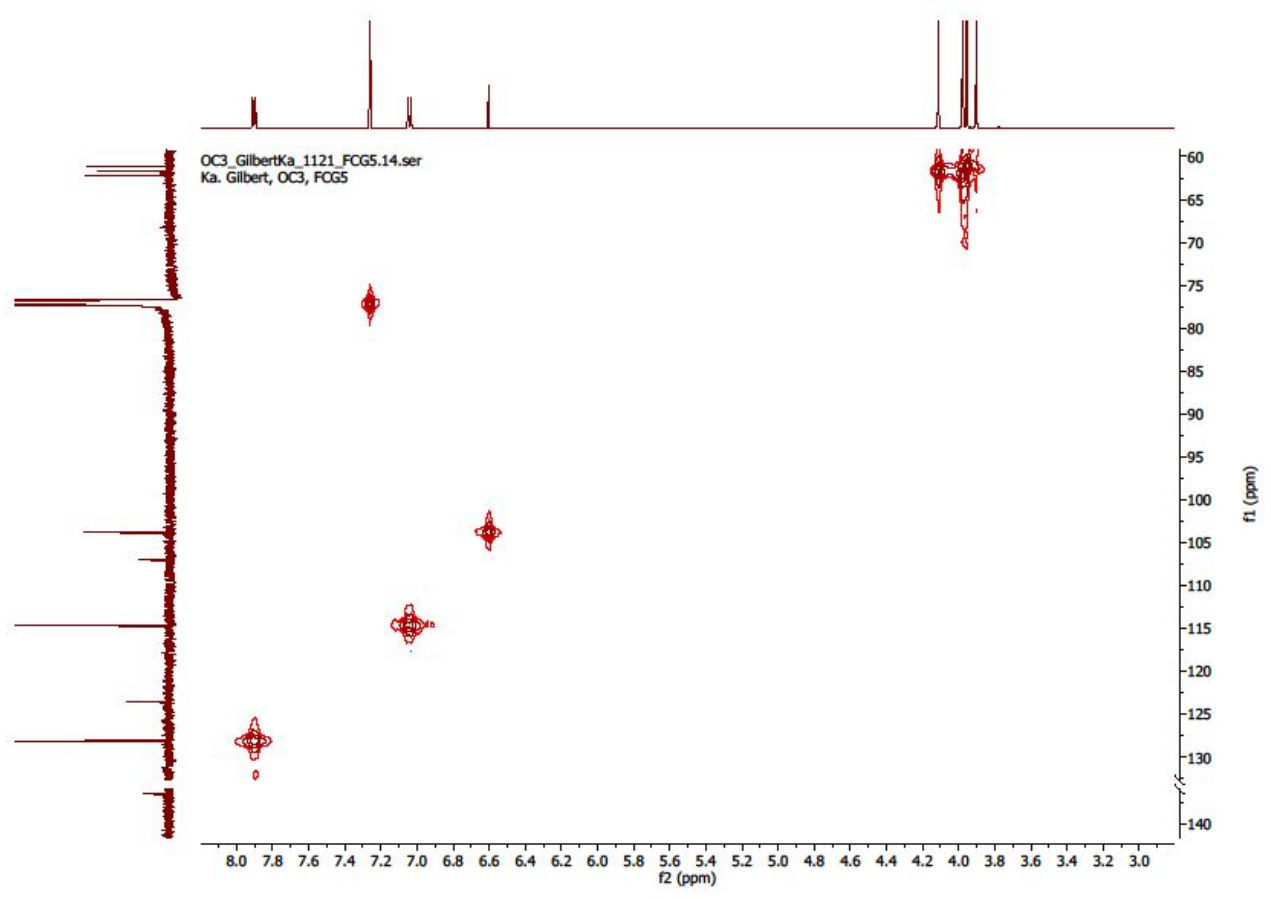

Figure S55: HSQC Spectrum of 5-OH-6,7,8,4'-Tetrametoxyflavone (11)

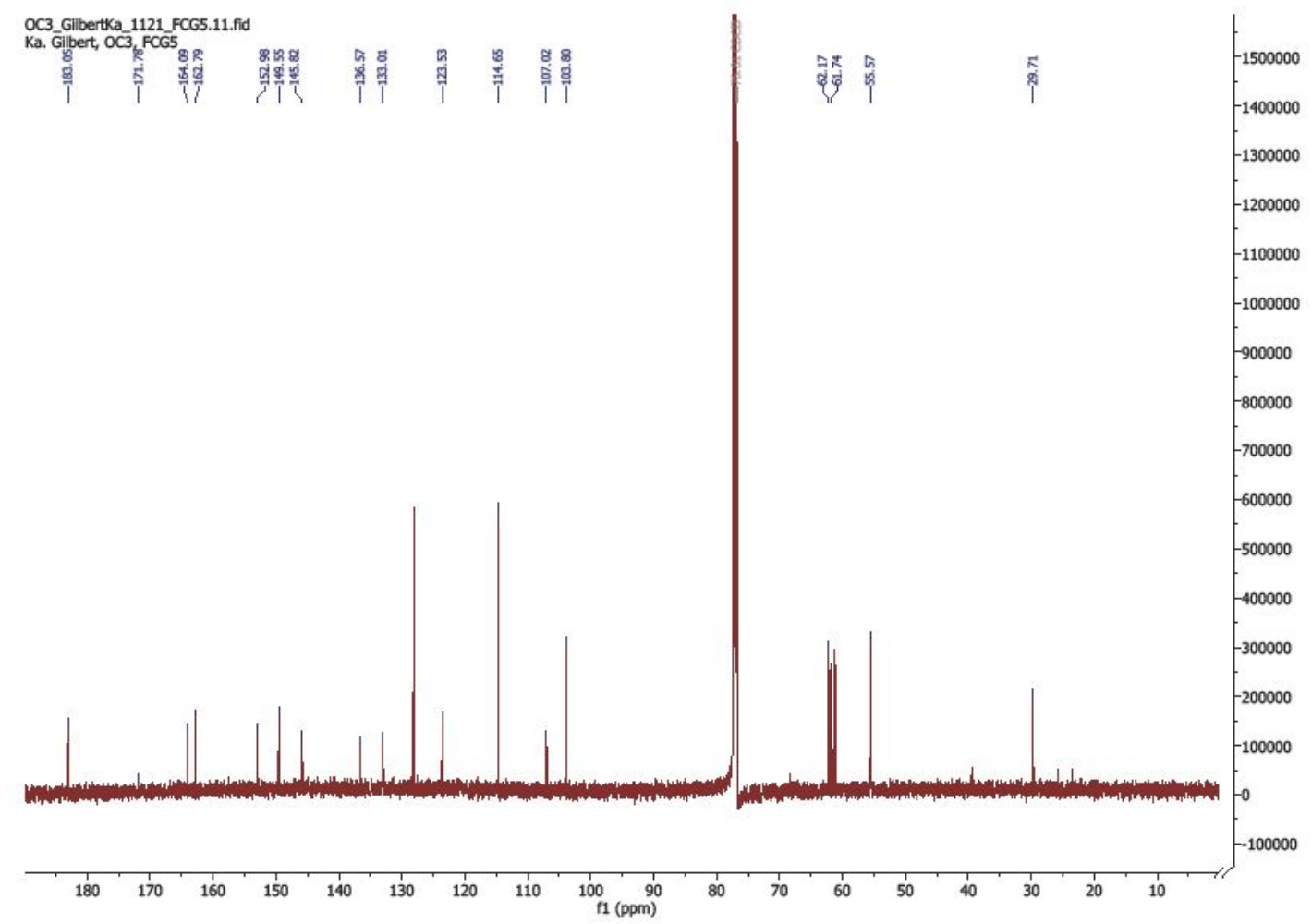

Figure S56: ${ }^{13} \mathrm{C}$ NMR Spectrum (125 MHz, $\mathrm{CDCl}_{3}$ ) of compound (11) (5-OH-6, 7,8,4'Tetrametoxyflavone) 


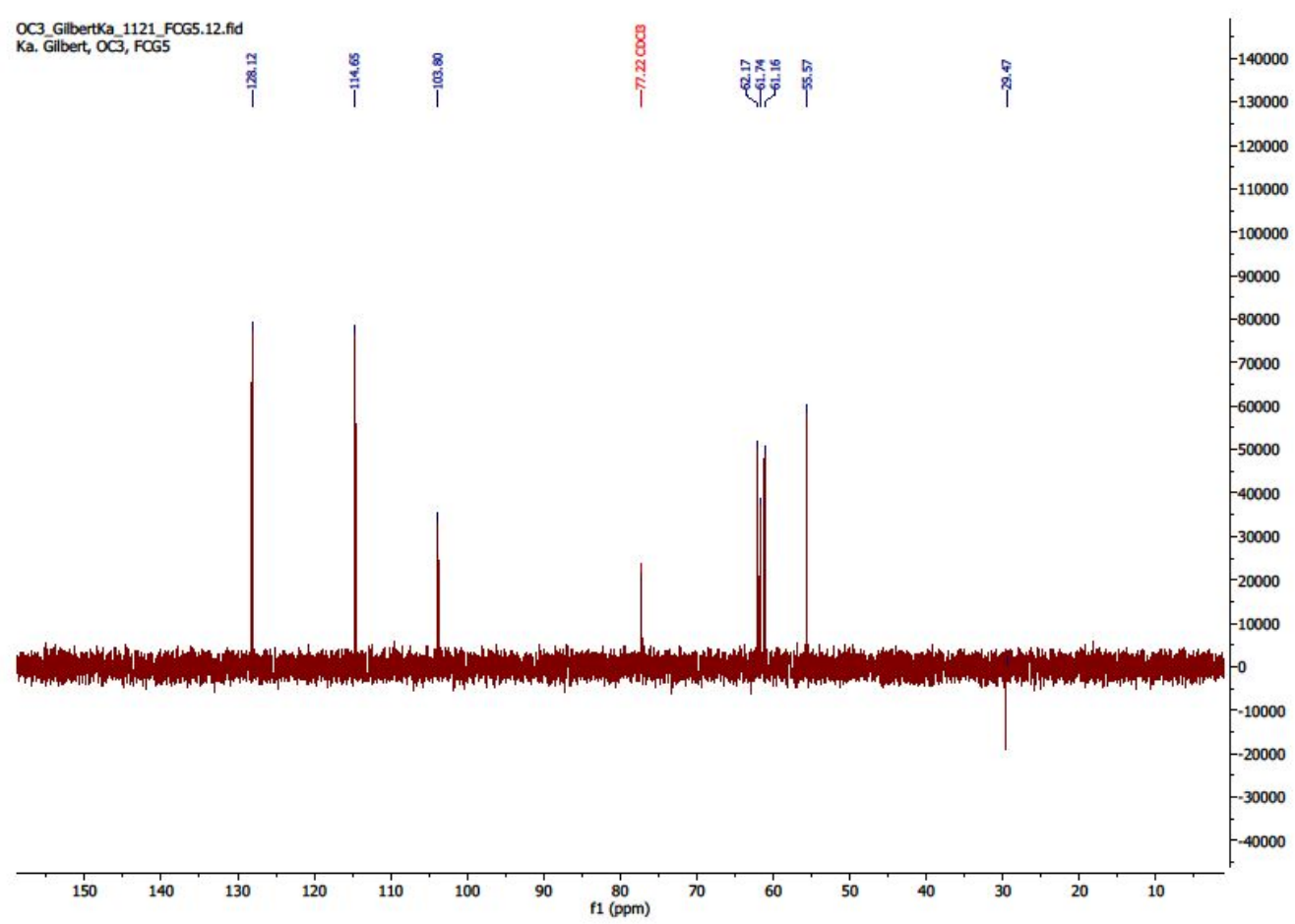

Figure S57: 135-DEPT Spectrum (125 MHz, $\left.\mathrm{CDCl}_{3}\right)$ of 5-OH-6, 7,8,4'-Tetrametoxyflavone (11)

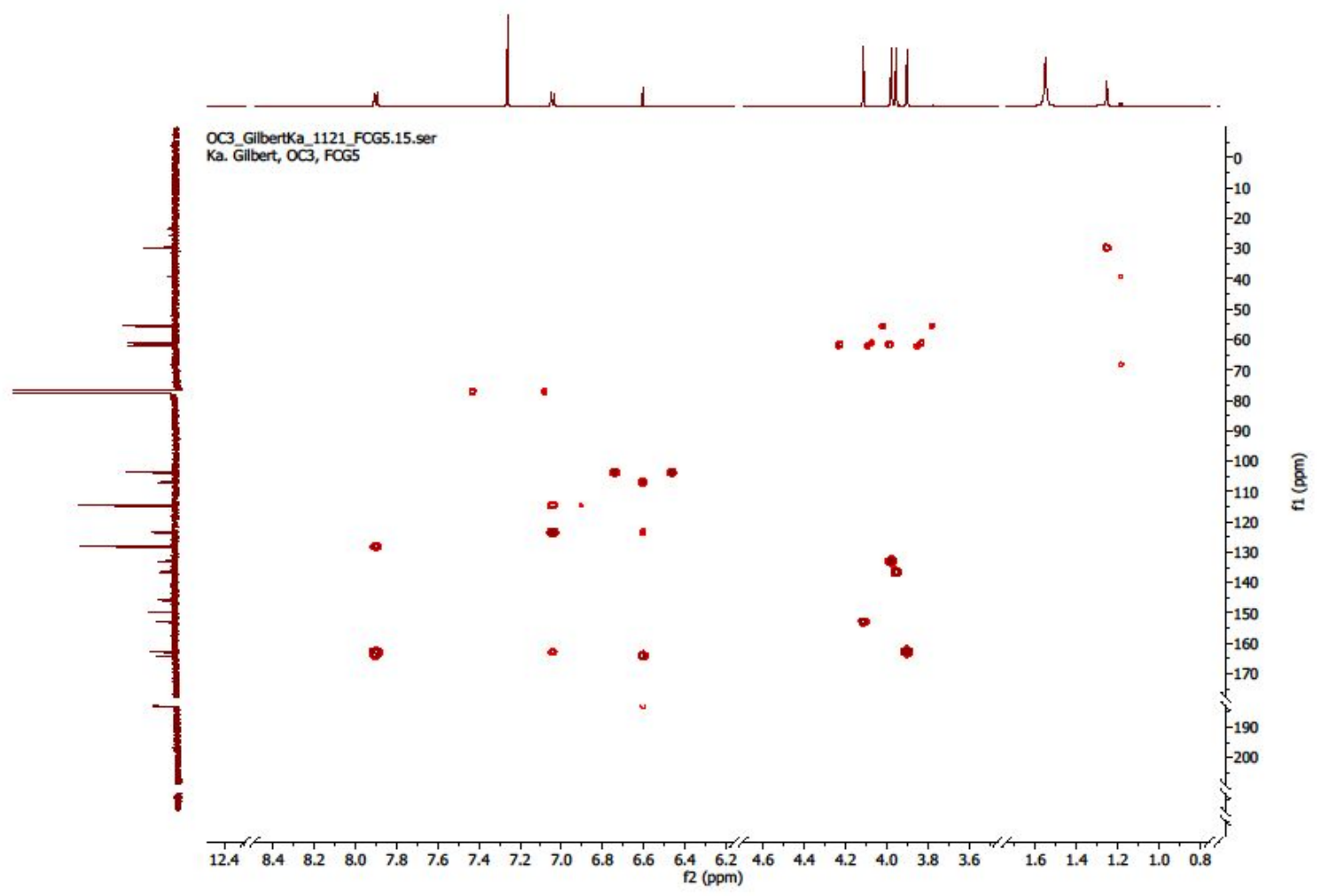

Figure S58: HMBC Spectrum of 5-OH-6, 7,8,4'-Tetrametoxyflavone (11) 


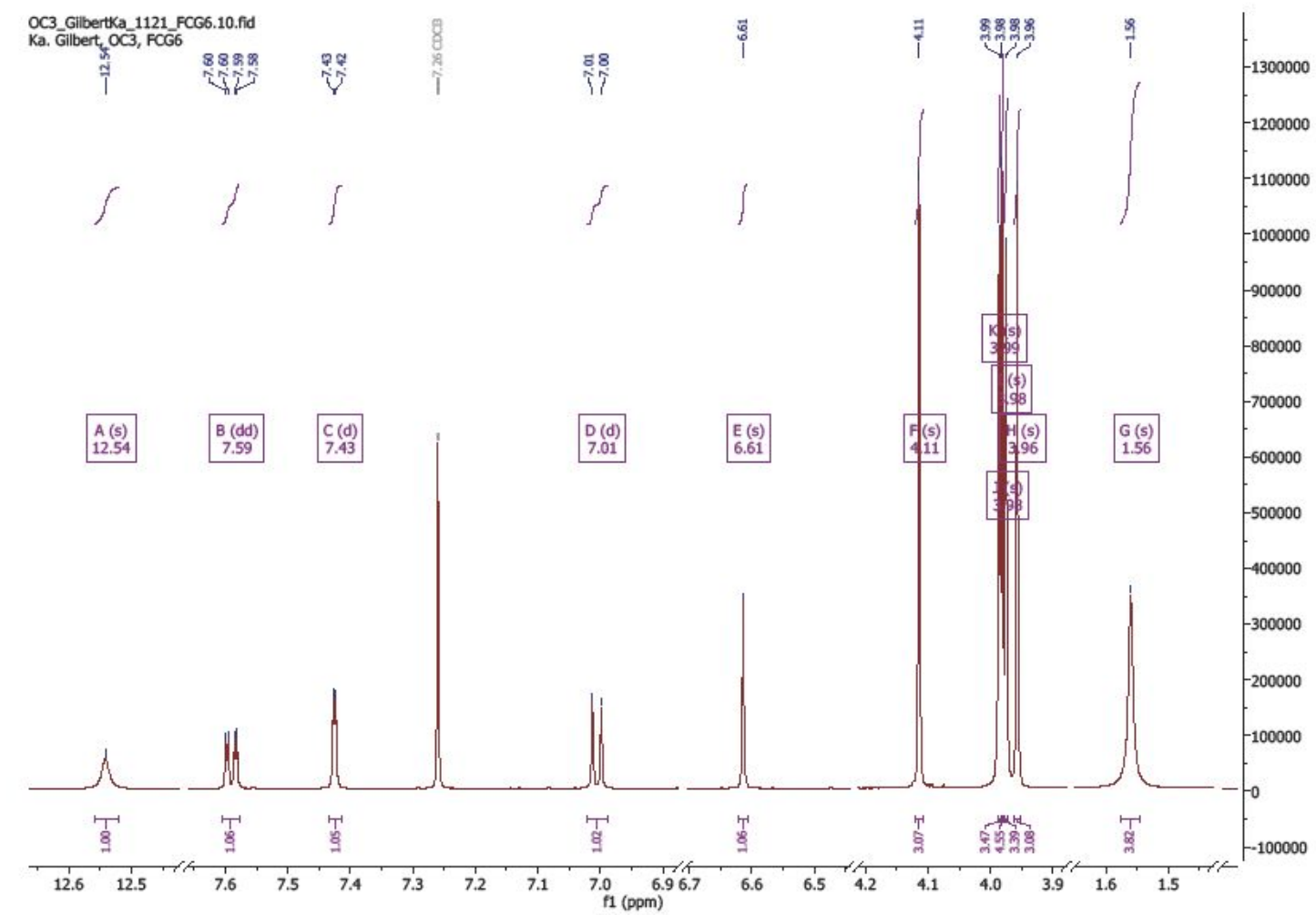

Figure S59: ${ }^{1} \mathrm{H}$ NMR Spectrum (500 MHz, $\mathrm{CDCl}_{3}$ ) of 5-OH-6,7,8,3',4'-Pentametoxyflavone (12)

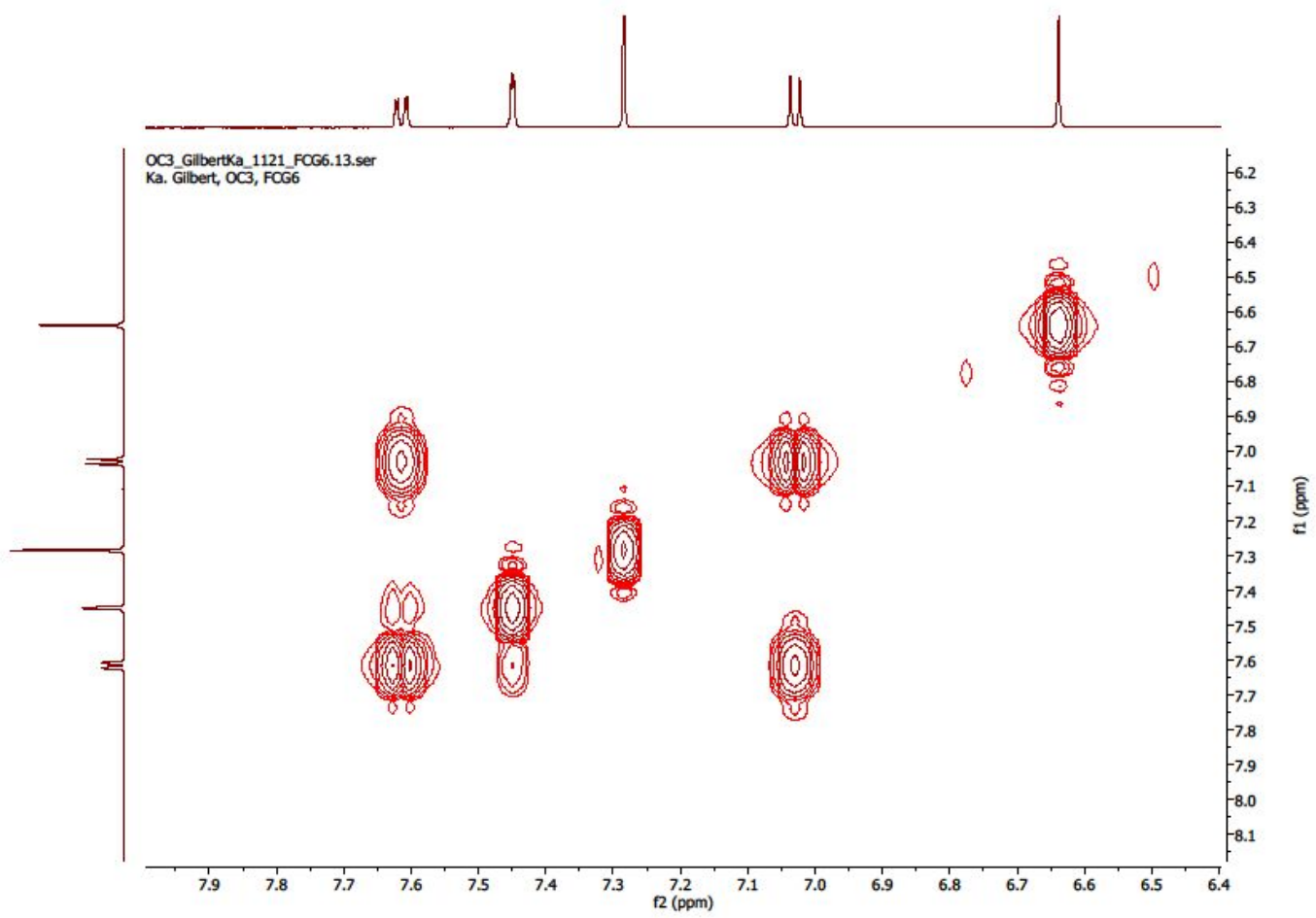

Figure S60: COSY Spectrum of 5-OH-6,7,8,3',4'-Pentametoxyflavone (12) 


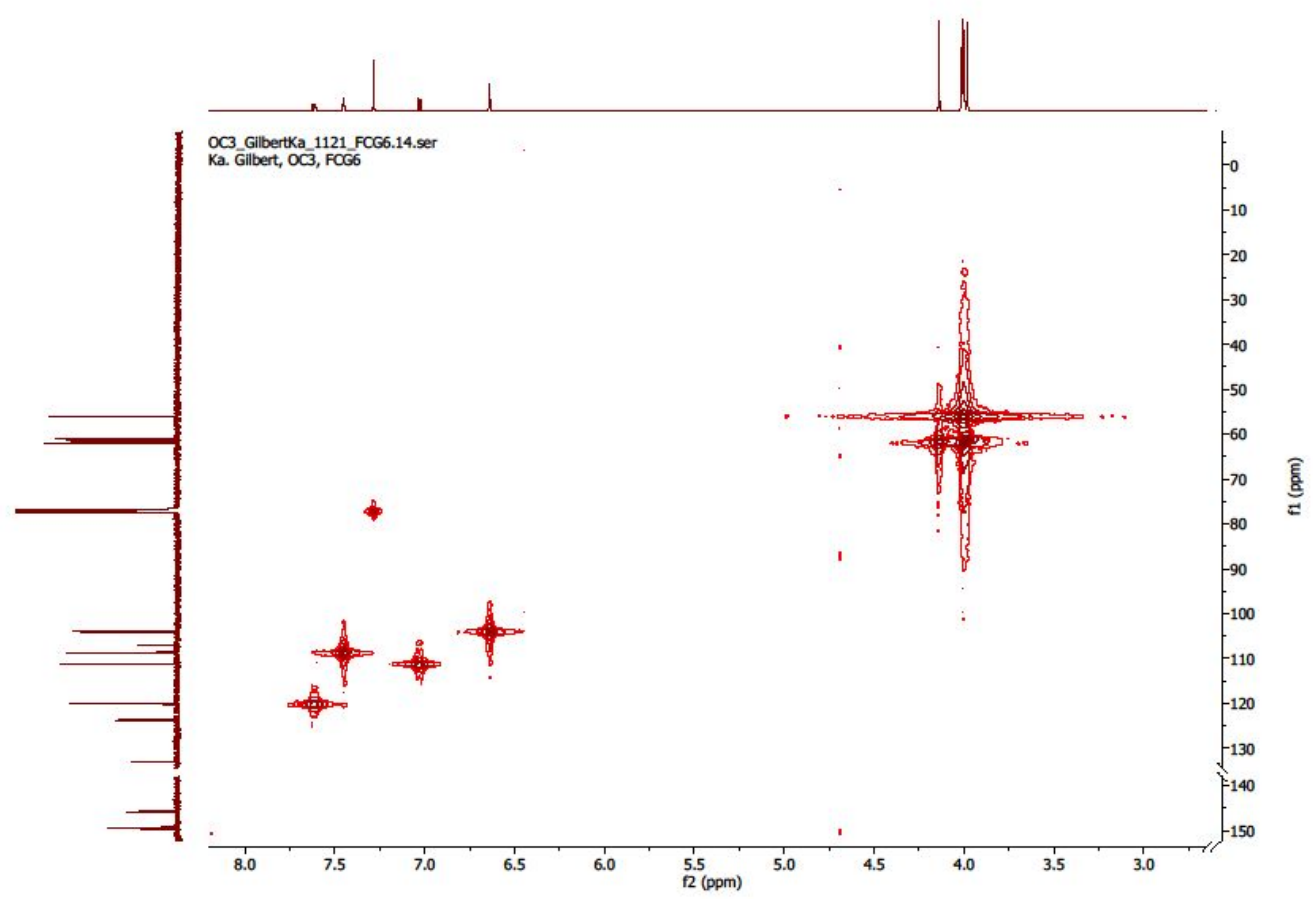

Figure S61: HSQC Spectrum of 5-OH-6, 7,8,3',4'-Pentametoxyflavone (12)

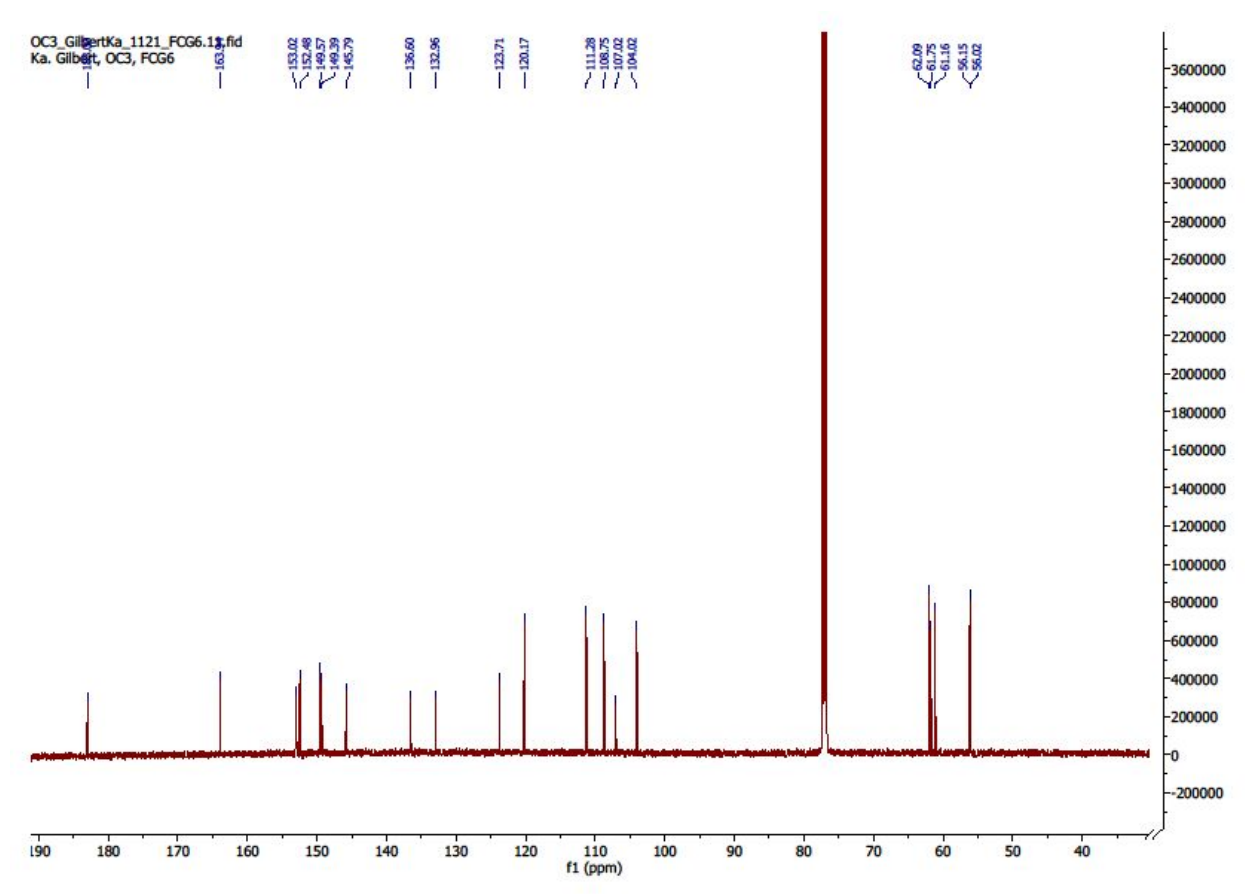

Figure S62: ${ }^{13} \mathrm{C}$ NMR Spectrum $\left(125 \mathrm{MHz}, \mathrm{CDCl}_{3}\right)$ of 5-OH-6,7,8,3',4'-Pentametoxyflavone (12) 


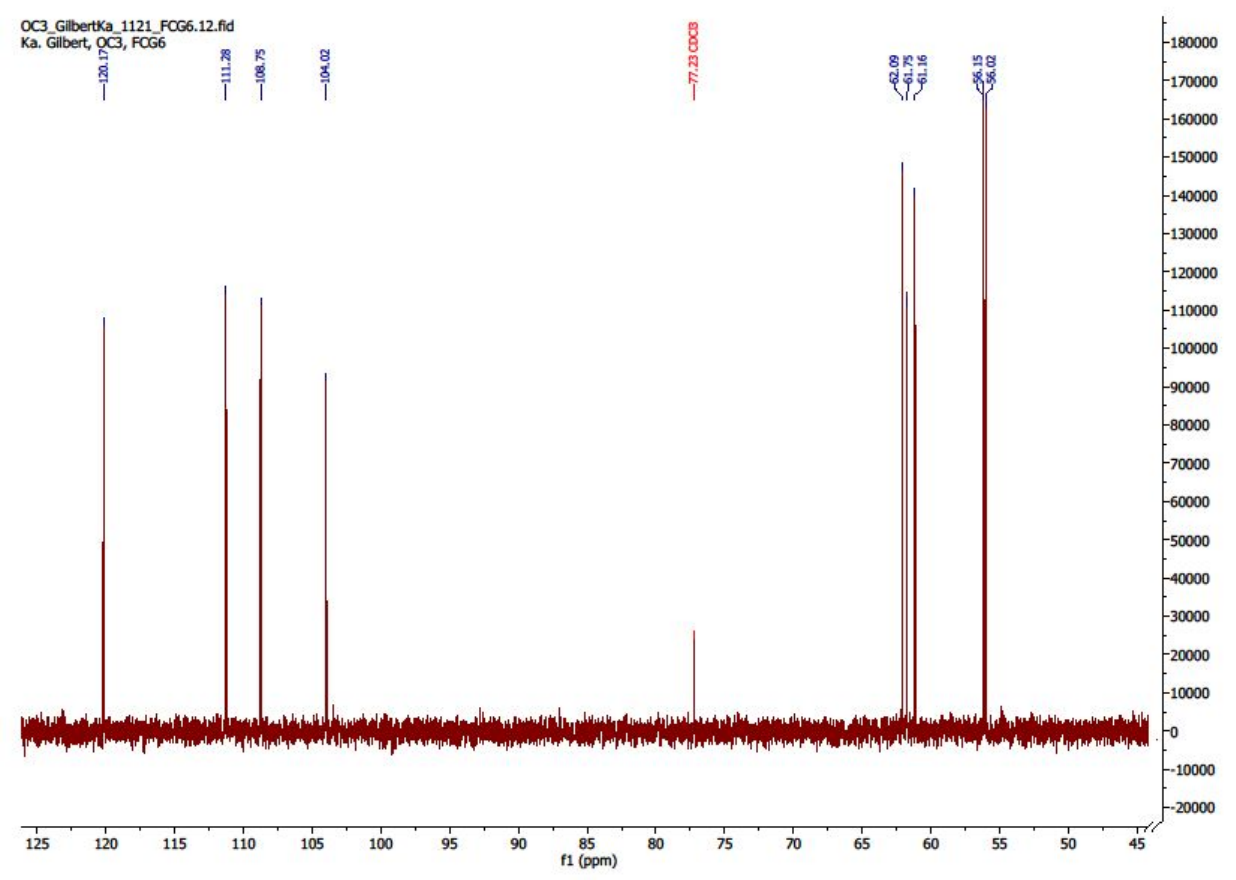

Figure S63: 135-DEPT Spectrum (125 MHz, $\left.\mathrm{CDCl}_{3}\right)$ of 5-OH-6,7,8,3',4'-Pentametoxyflavone (12)

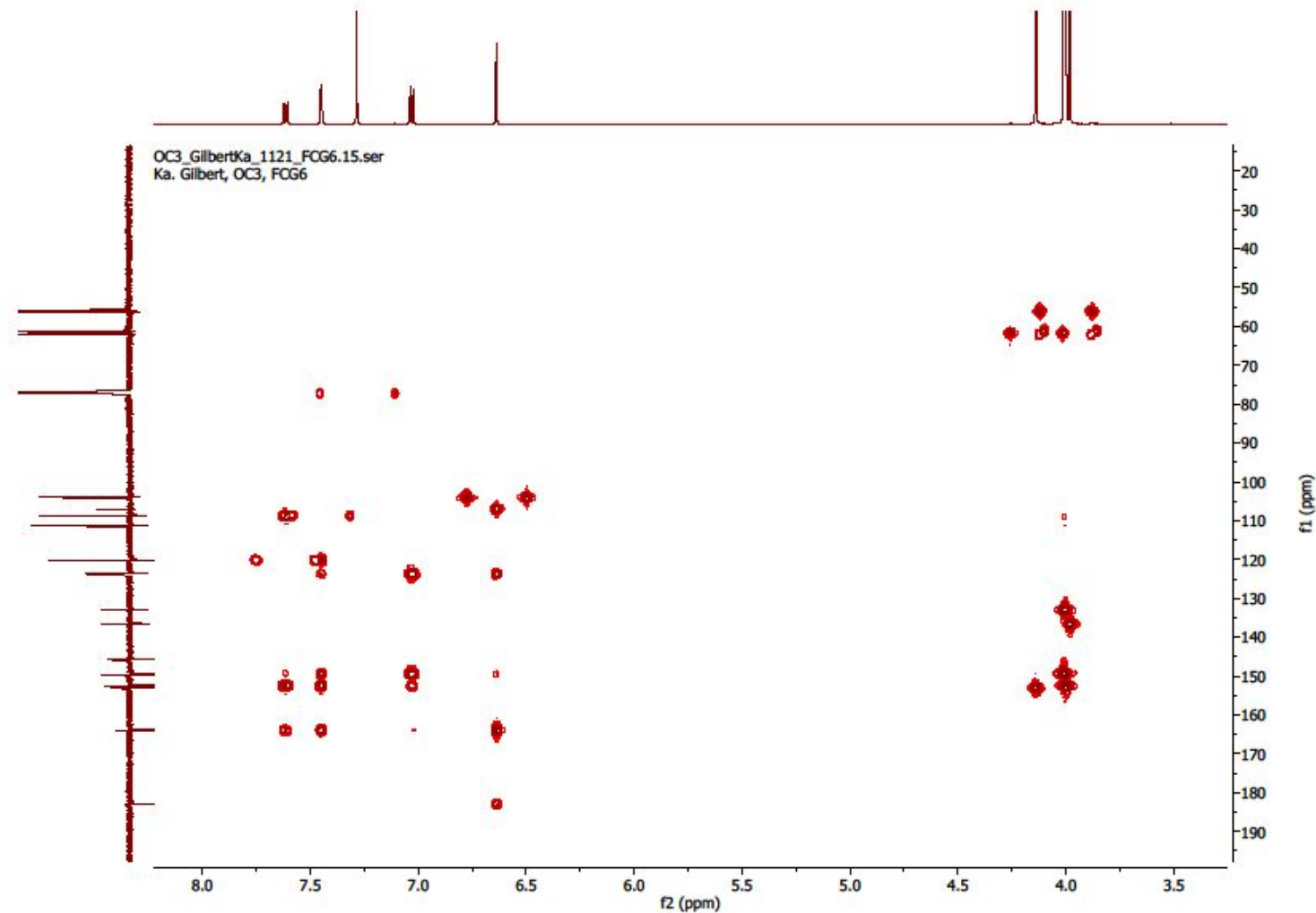

Figure S64: HMBC Spectrum of 5-OH-6,7,8,3',4'-Pentametoxyflavone (12) 


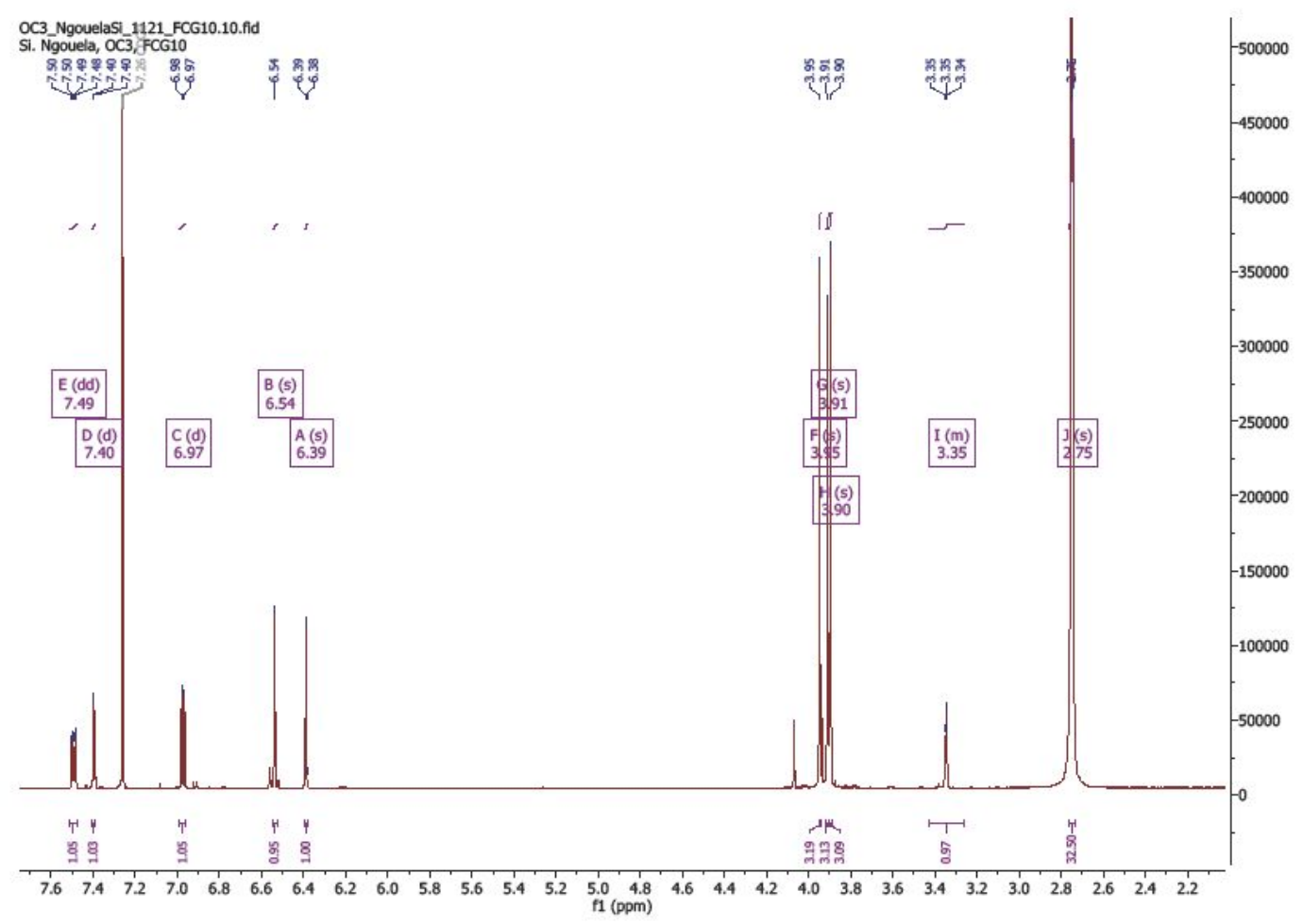

Figure S65: ' $\mathrm{H}$ NMR Spectrum (500 MHz, $\mathrm{CDCl}_{3}$ ) of 5,4'-d ihydroxy-6,7,3'Trimetoxyflavone (13)

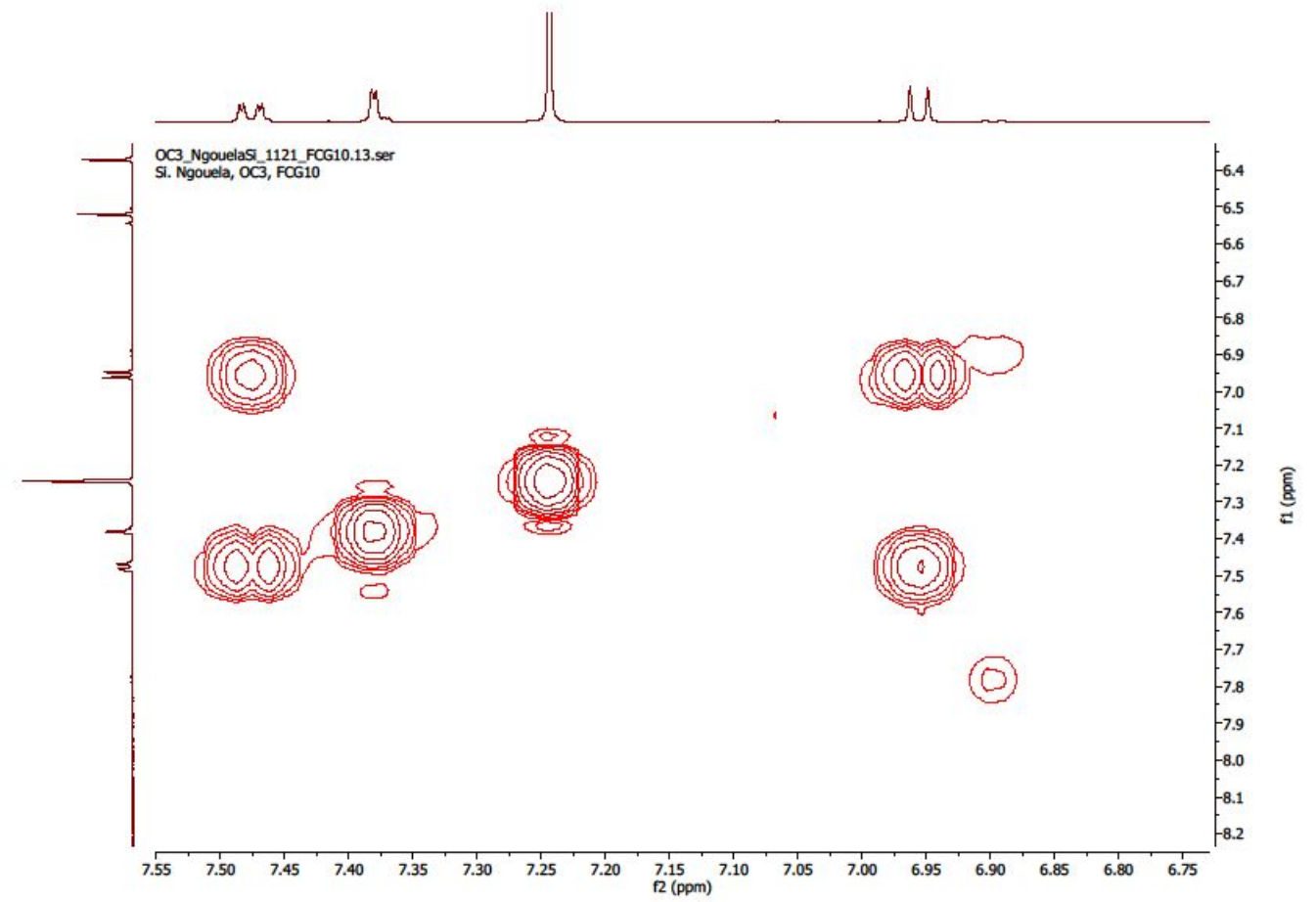

Figure S66: HMBC Spectrum of 5,4'-d ihydroxy-6,7,3'-Trimetoxyflavone (13) 


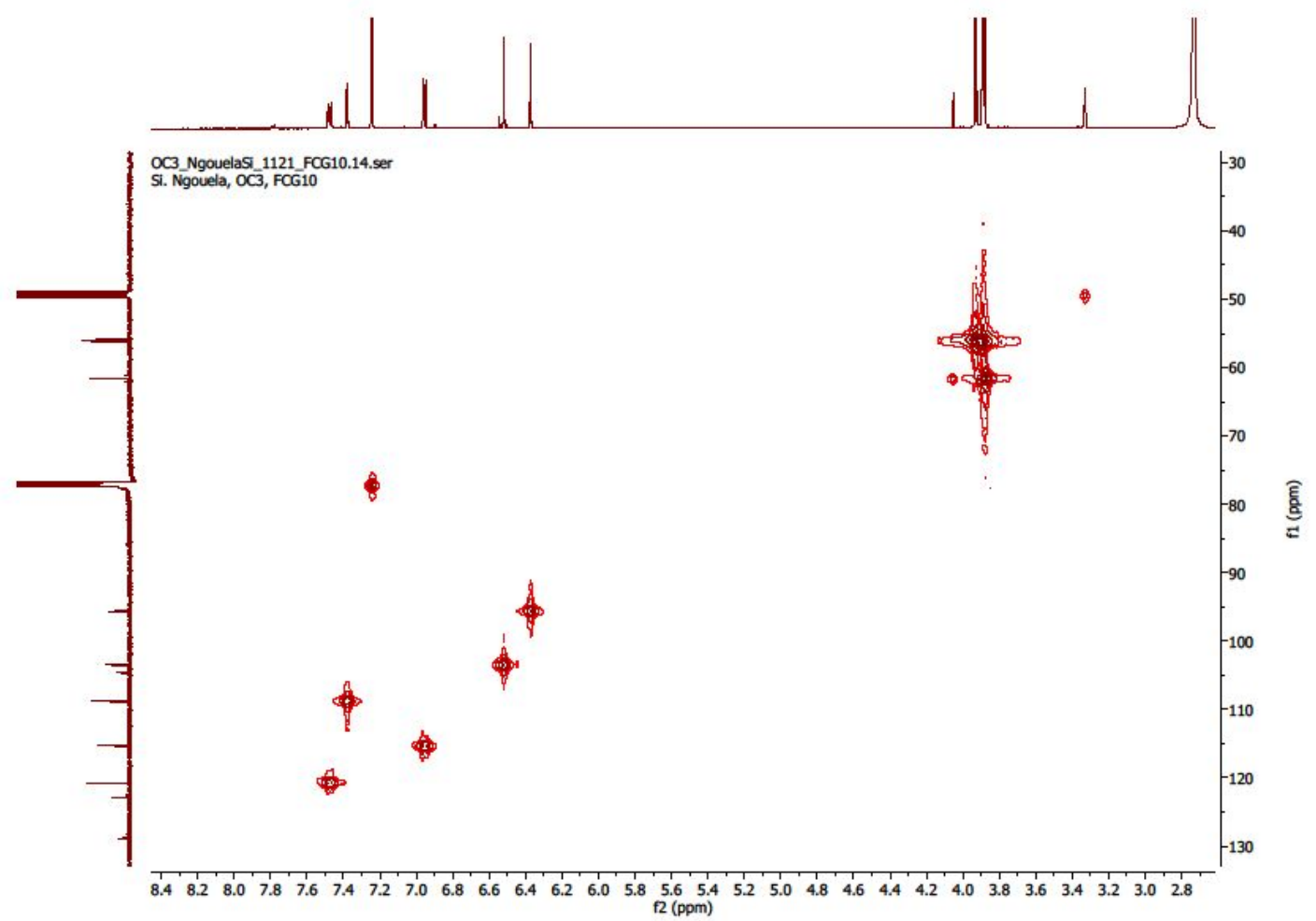

Figure S67: HMBC Spectrum of 5,4'-d ihydroxy-6,7,3'-Trimetoxyflavone (13)

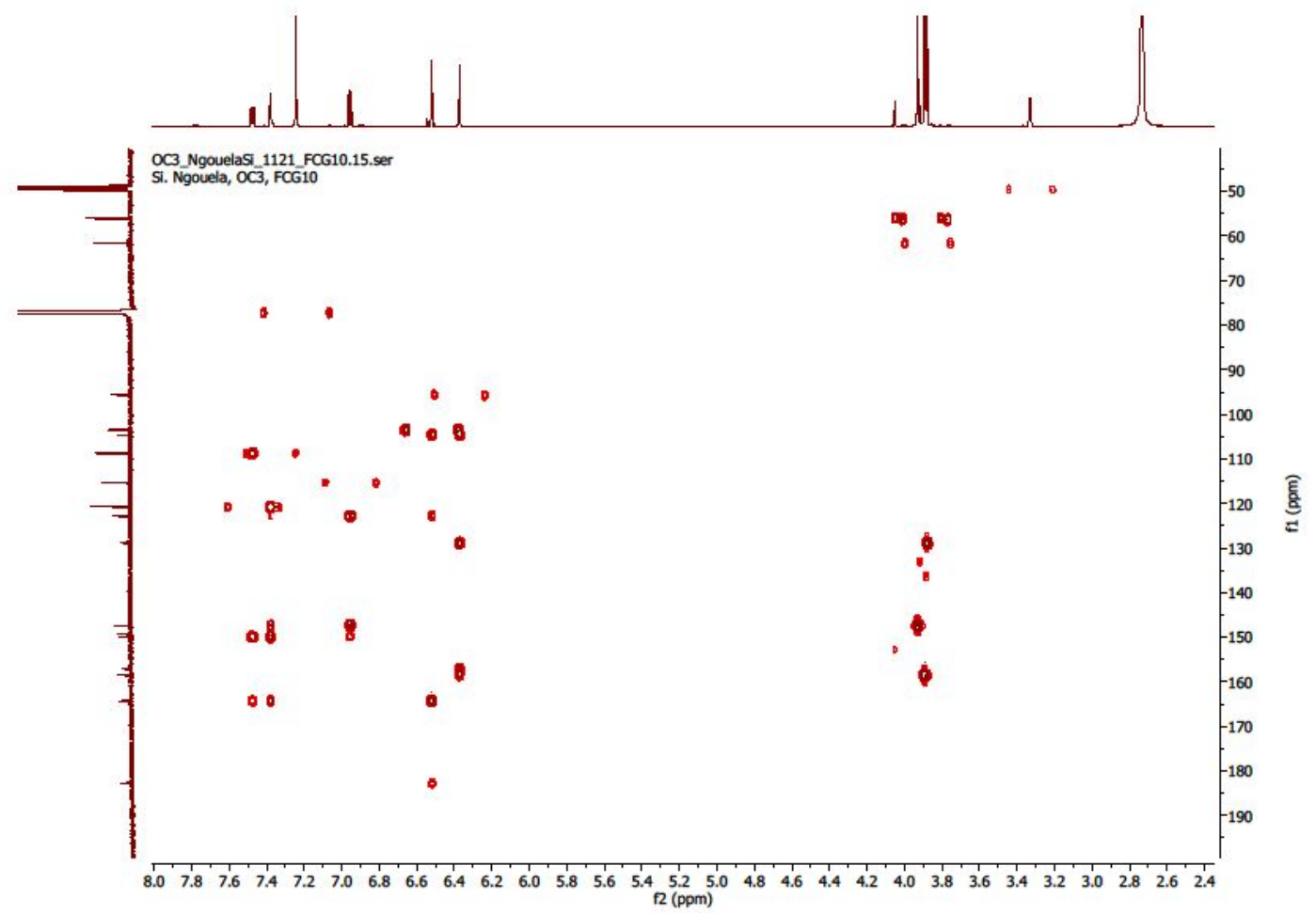

Figure S68: HMBC Spectrum of 5,4'-d ihydroxy-6, 7,3'-Trimetoxyflavone (13) 


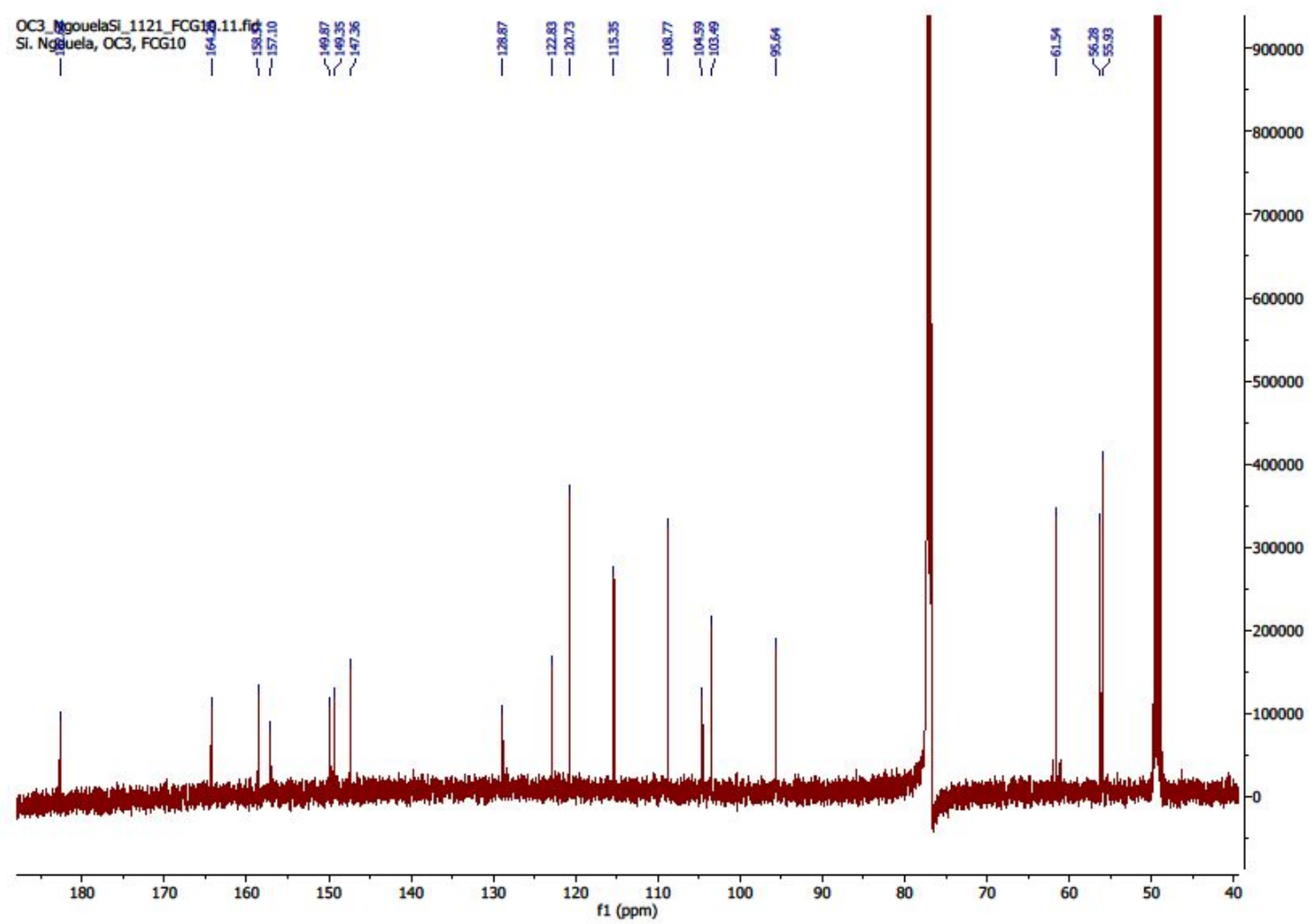

Figure S69: ${ }^{13} \mathrm{CNMR}$ Spectrum (125 MHz, $\left.\mathrm{CDCl}_{3}\right)$ of 5,4'-d ihydroxy-6, 7,3'Trimetoxyflavone (13)

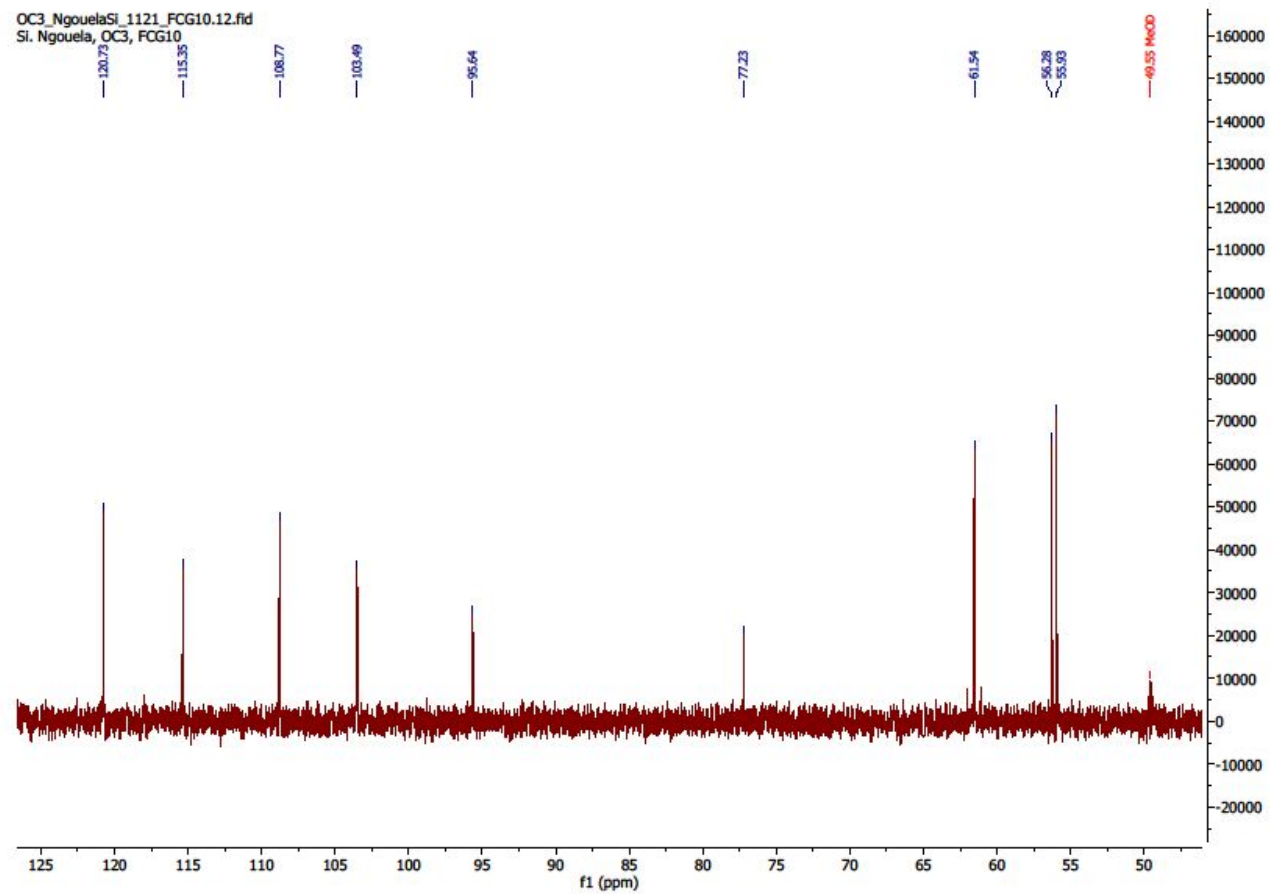

Figure S70: 135-DEPT Spectrum $\left(125 \mathrm{MHz}, \mathrm{CDCl}_{3}\right)$ of 5,4'-d ihydroxy-6,7,3'Trimetoxyflavone (13) 


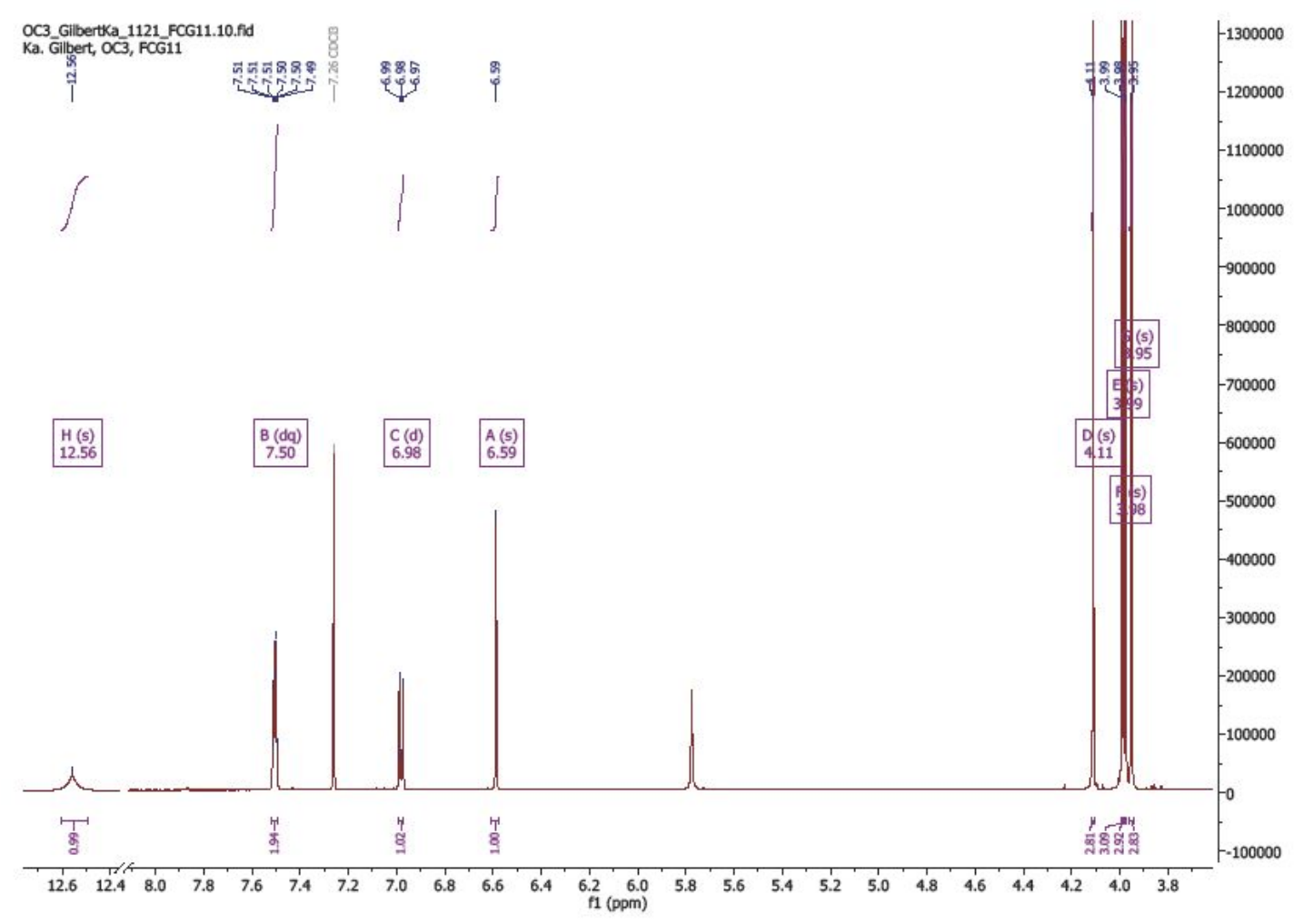

Figure S71: ' $\mathrm{H}$ NMR Spectrum (500 MHz, $\mathrm{CDCl}_{3}$ ) of 5,4'-dihydroxy-6, 7,8,3'Tetrametoxyflavone (14)

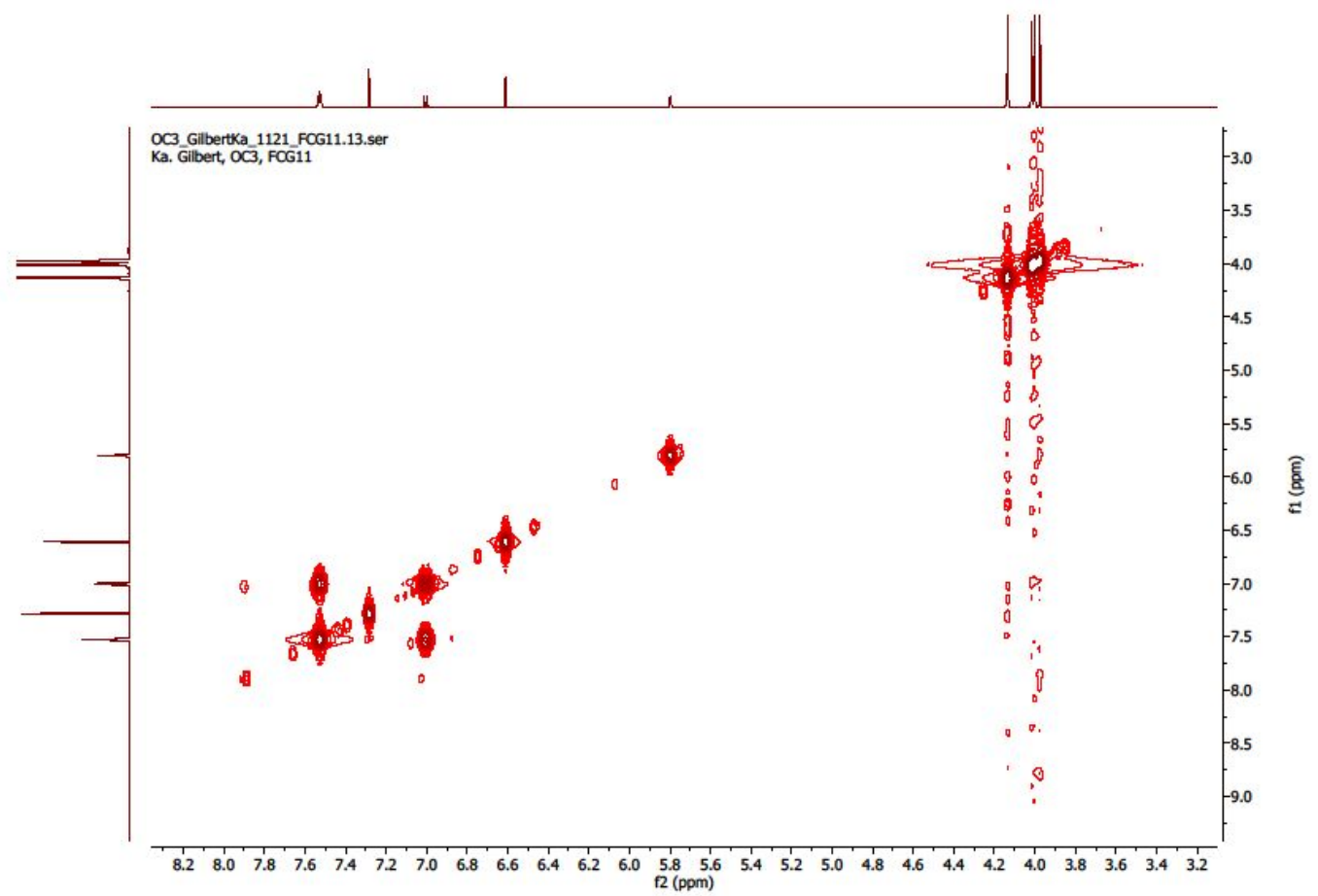

Figure S72: COSY Spectrum of 5,4'-dihydroxy-6,7,8,3'-Tetrametoxyflavone (14) 


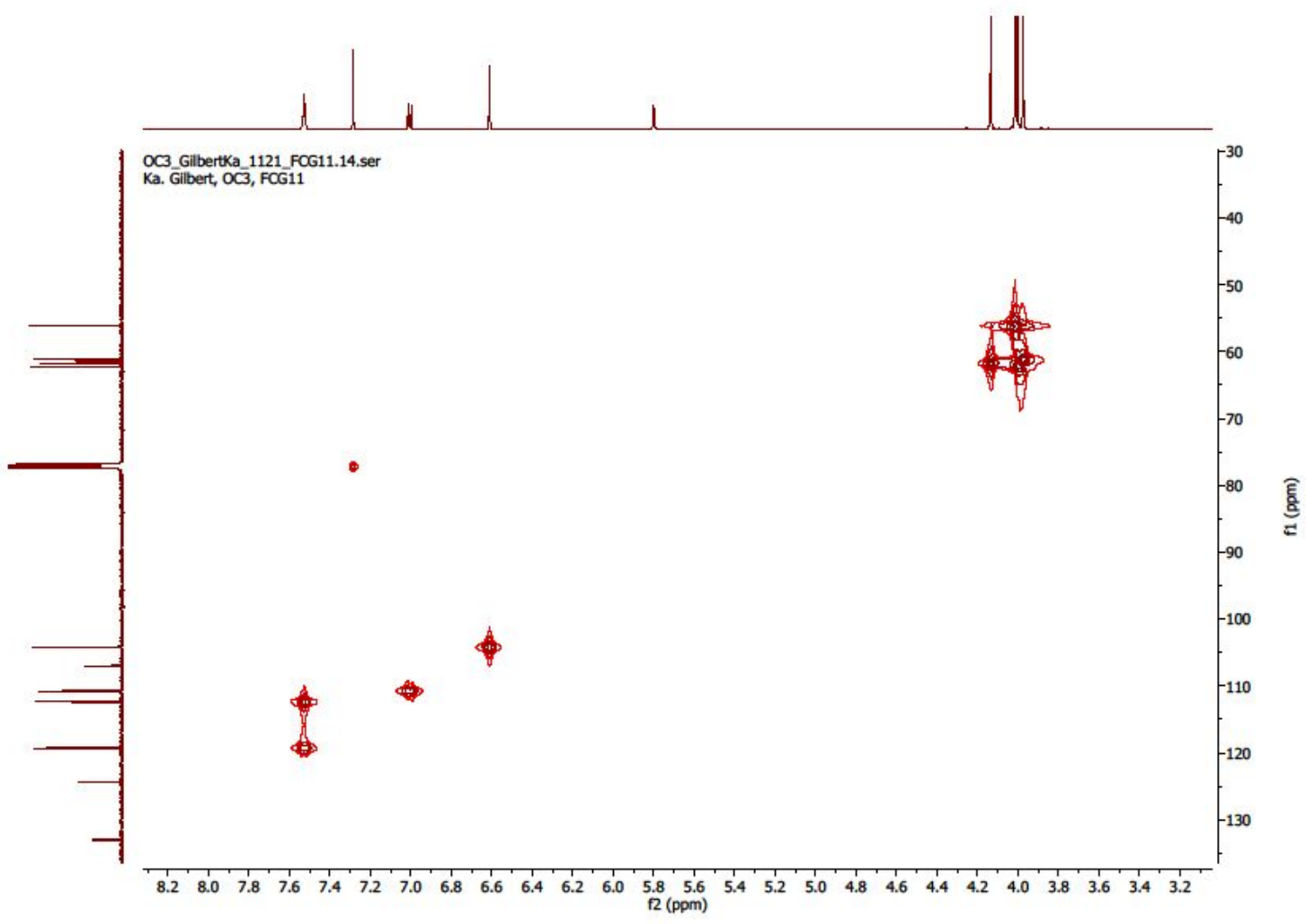

Figure S73: HSQC Spectrum of 5,4'-dihydroxy-6,7,8,3'-Tetrametoxyflavone (14)

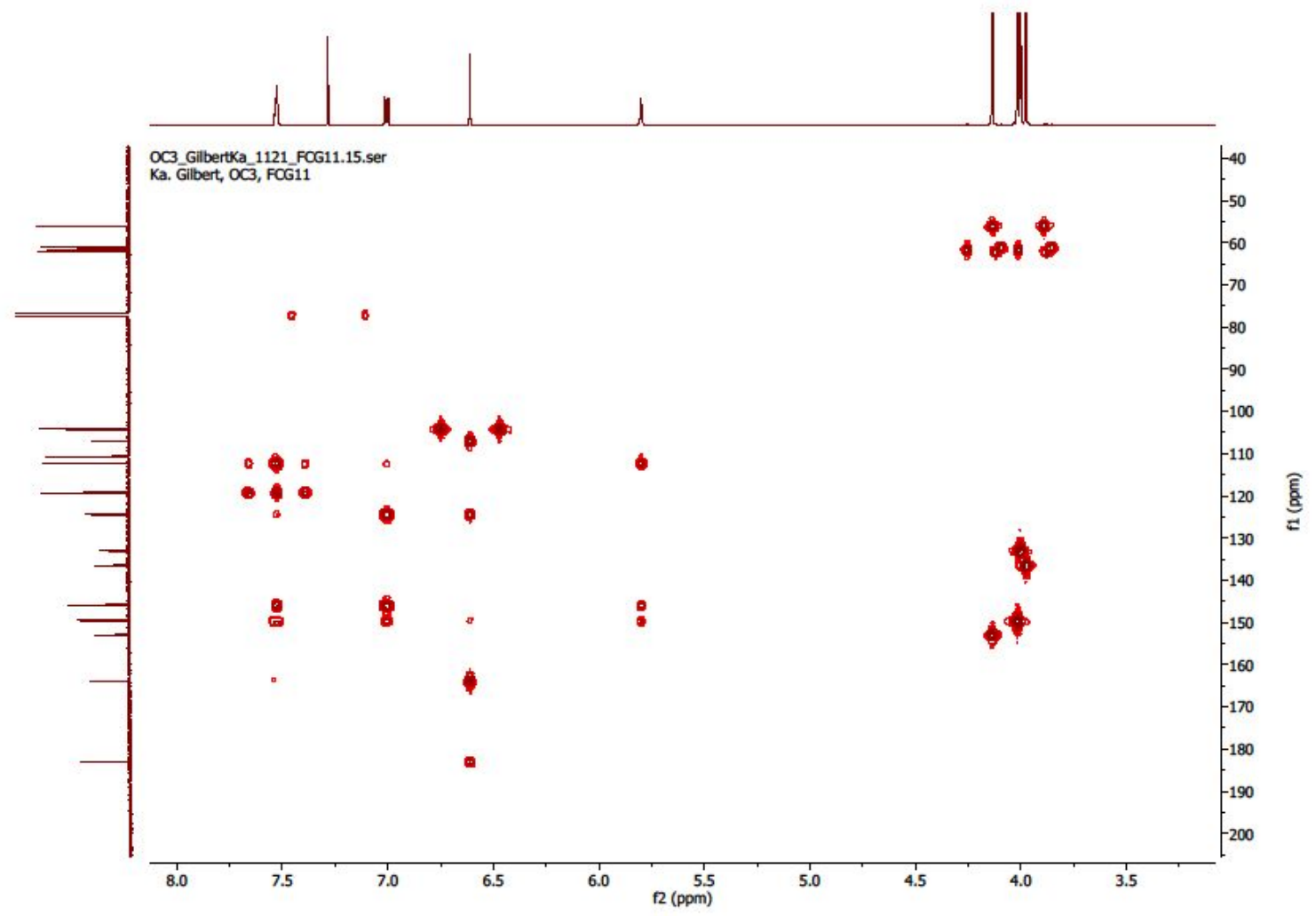

Figure S74: HMBC Spectrum of 5,4'-dihydroxy-6, 7,8,3'-Tetrametoxyflavone (14) 


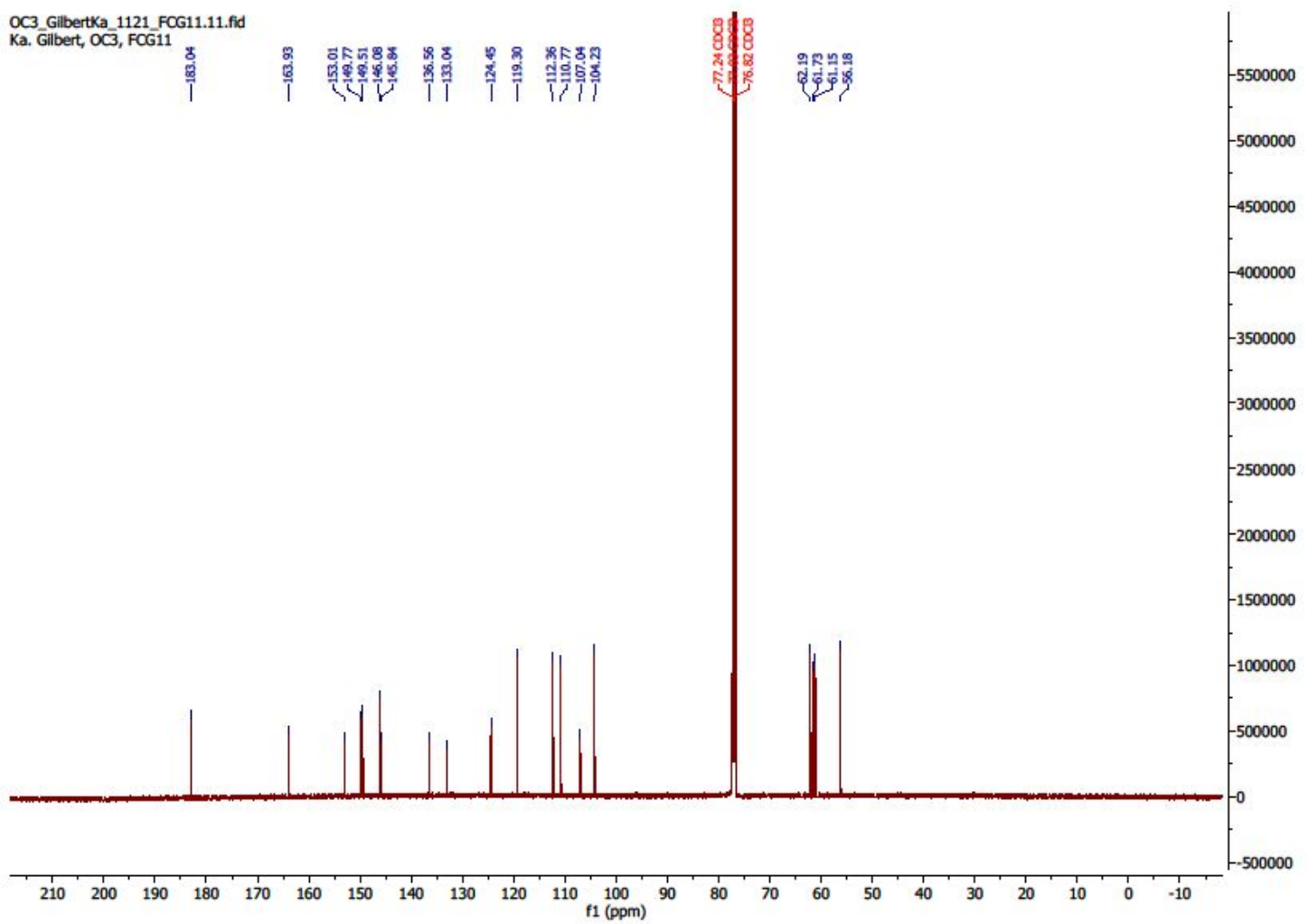

Figure S75: ${ }^{13} \mathrm{C} N M R$ Spectrum $\left(125 \mathrm{MHz}, C D C l_{3}\right)$ of 5,4'-dihydroxy-6,7,8,3'Tetrametoxyflavone (14)

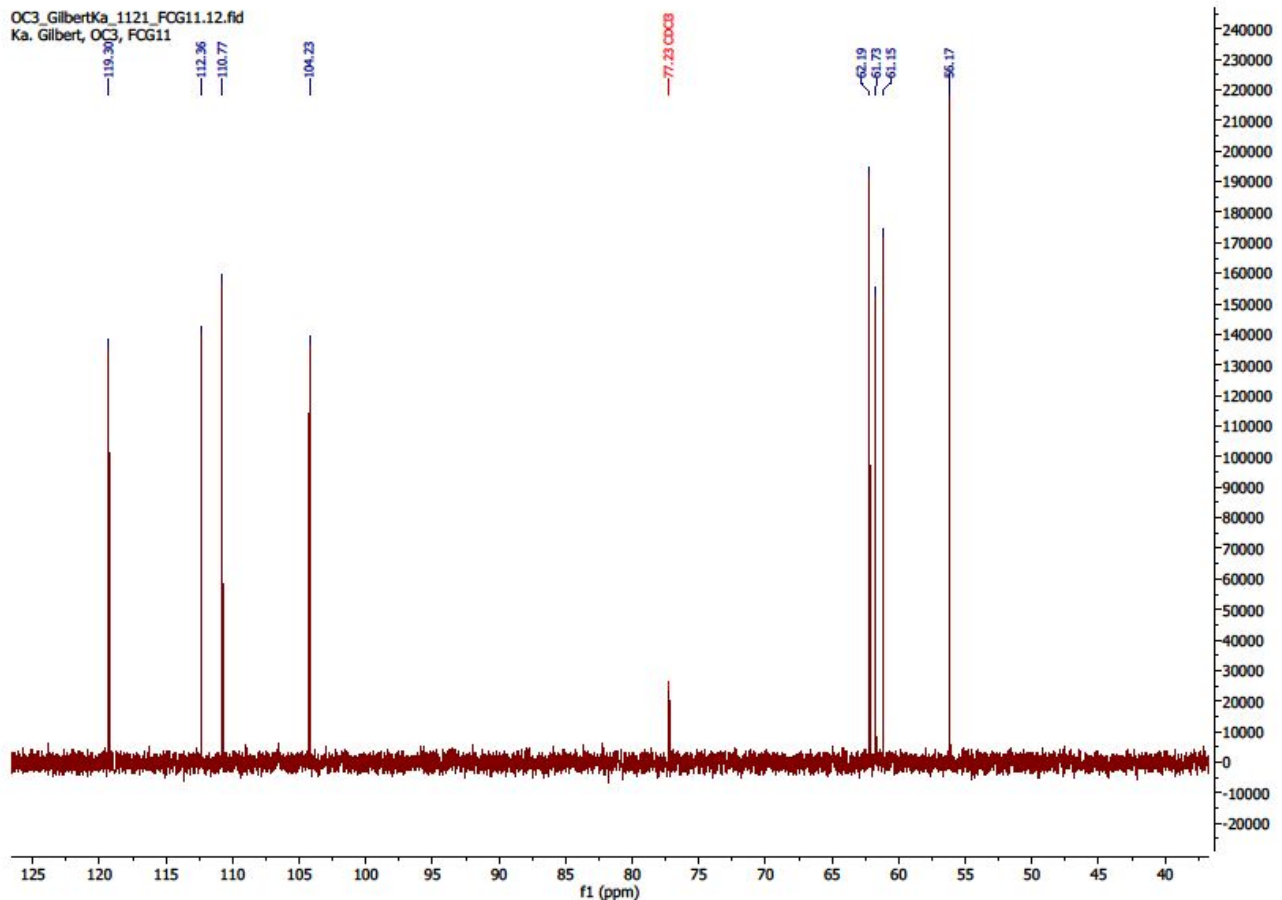

Figure S76: 135-DEPT Spectrum (125 MHz, $C D C l_{3}$ ) of 5,4'-dihydroxy-6, 7,8,3'Tetrametoxyflavone (14) 


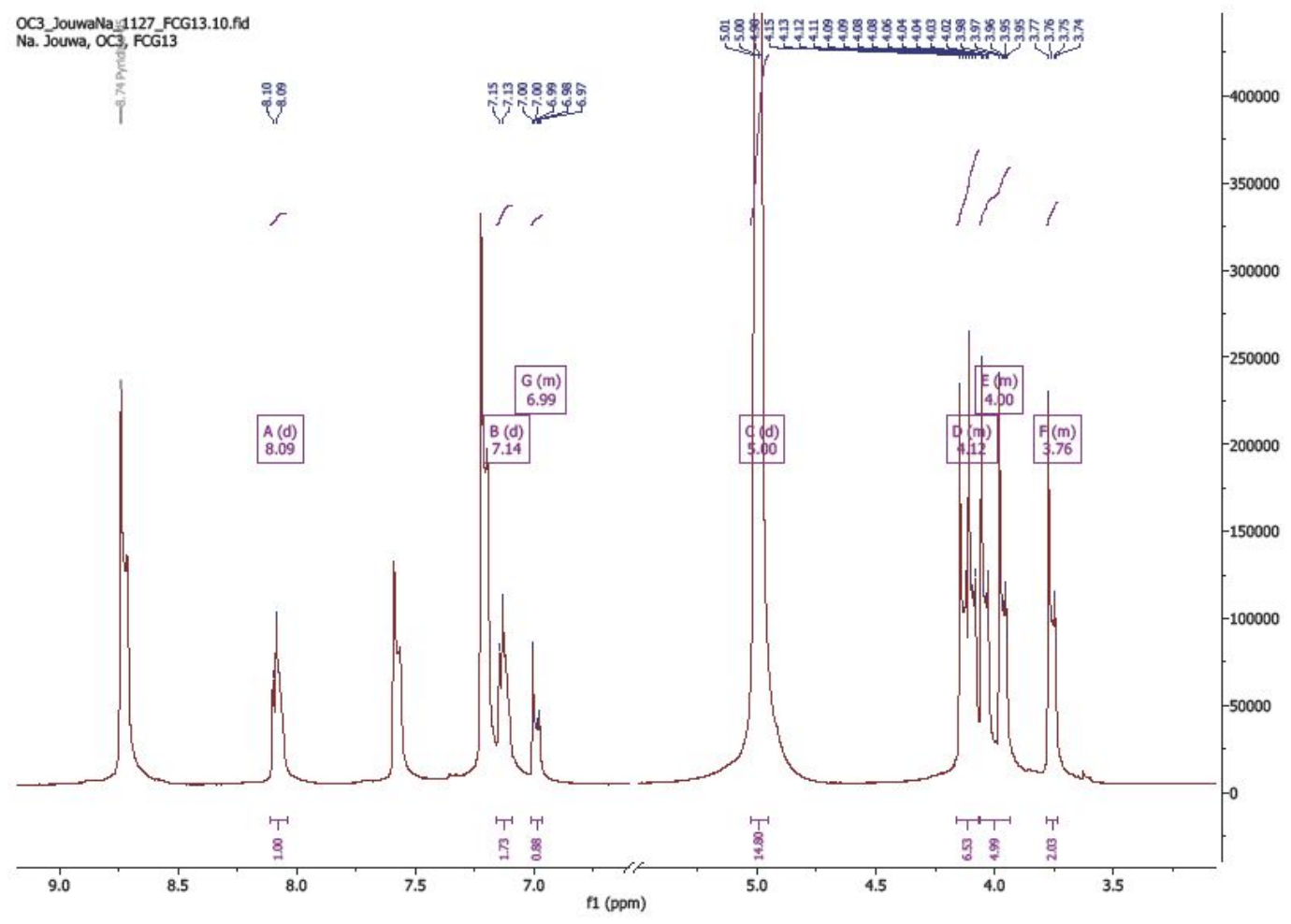

Figure S77: ${ }^{1} H$ NMR Spectrum (500 MHz, Pyridin-d ) $_{\text {) }}$ 5, 6, 7,8,4'-Pentametoxyflavone (15)

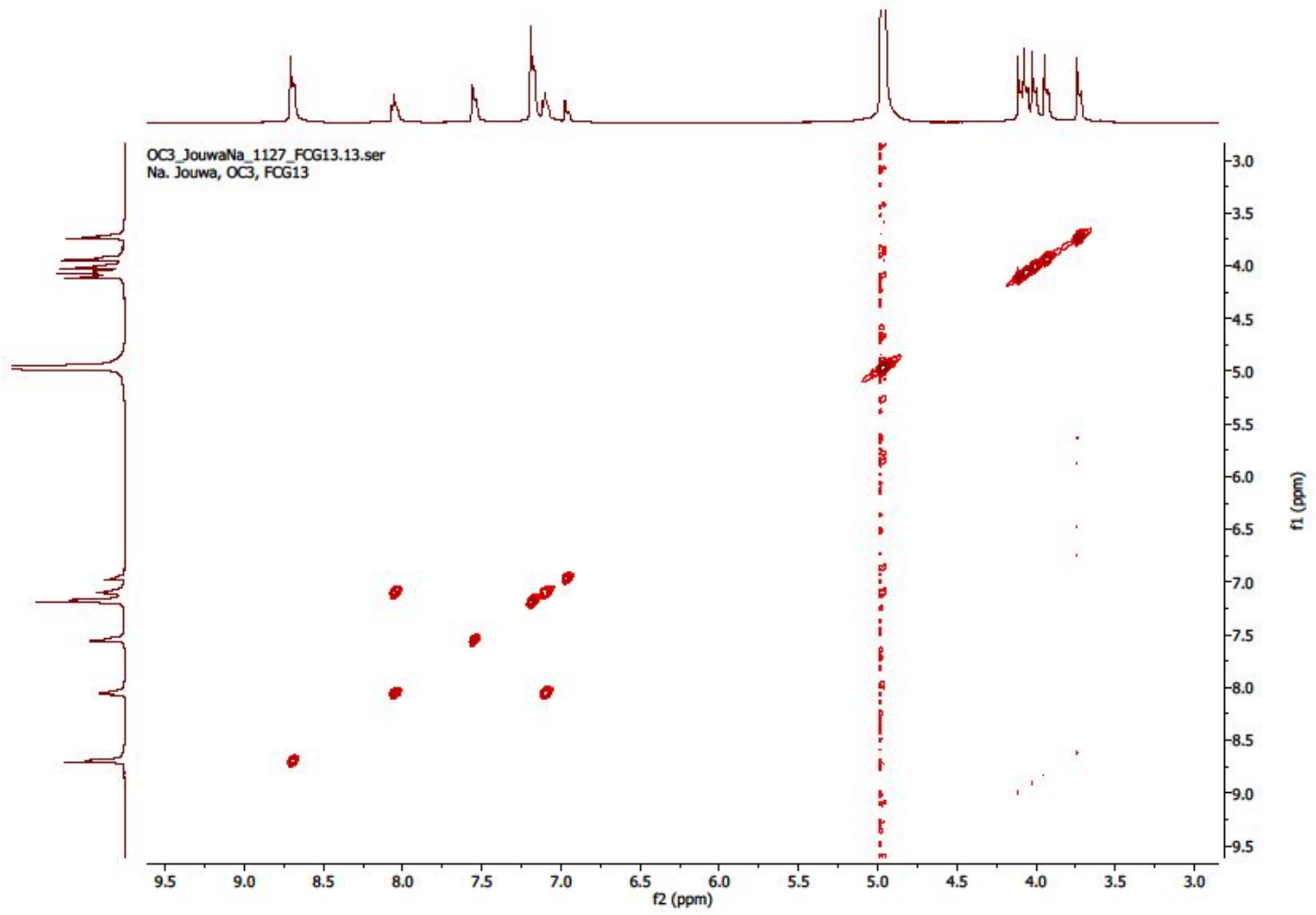

Figure S78: COSY Spectrum of 5,6,7,8,4'-Pentametoxyflavone (15) 


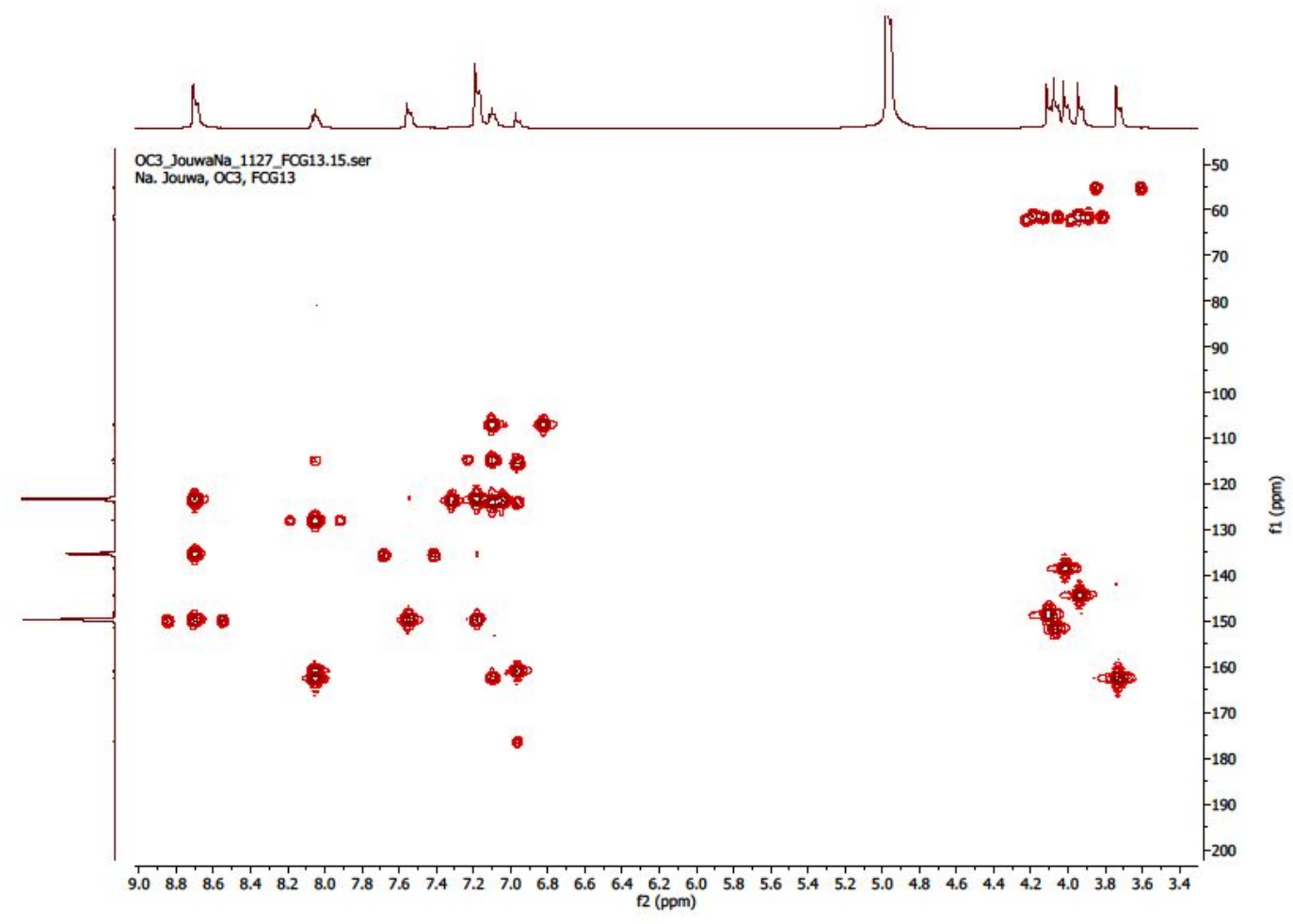

Figure S79: HMBC Spectrum of 5,6, 7,8,4'-Pentametoxyflavone (15)

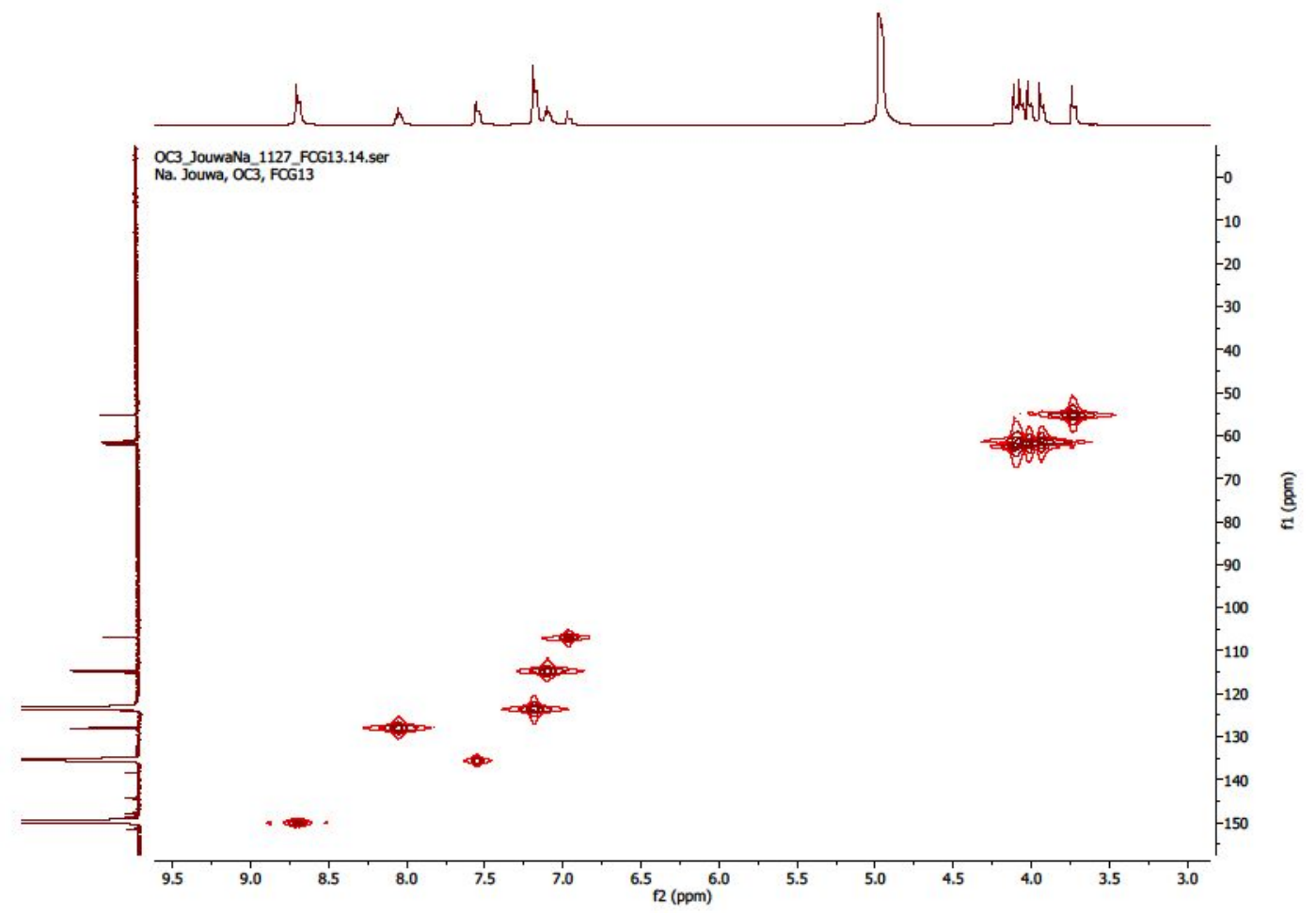

Figure S80: HSQC Spectrum of 5,6,7,8,4'-Pentametoxyflavone (15) 


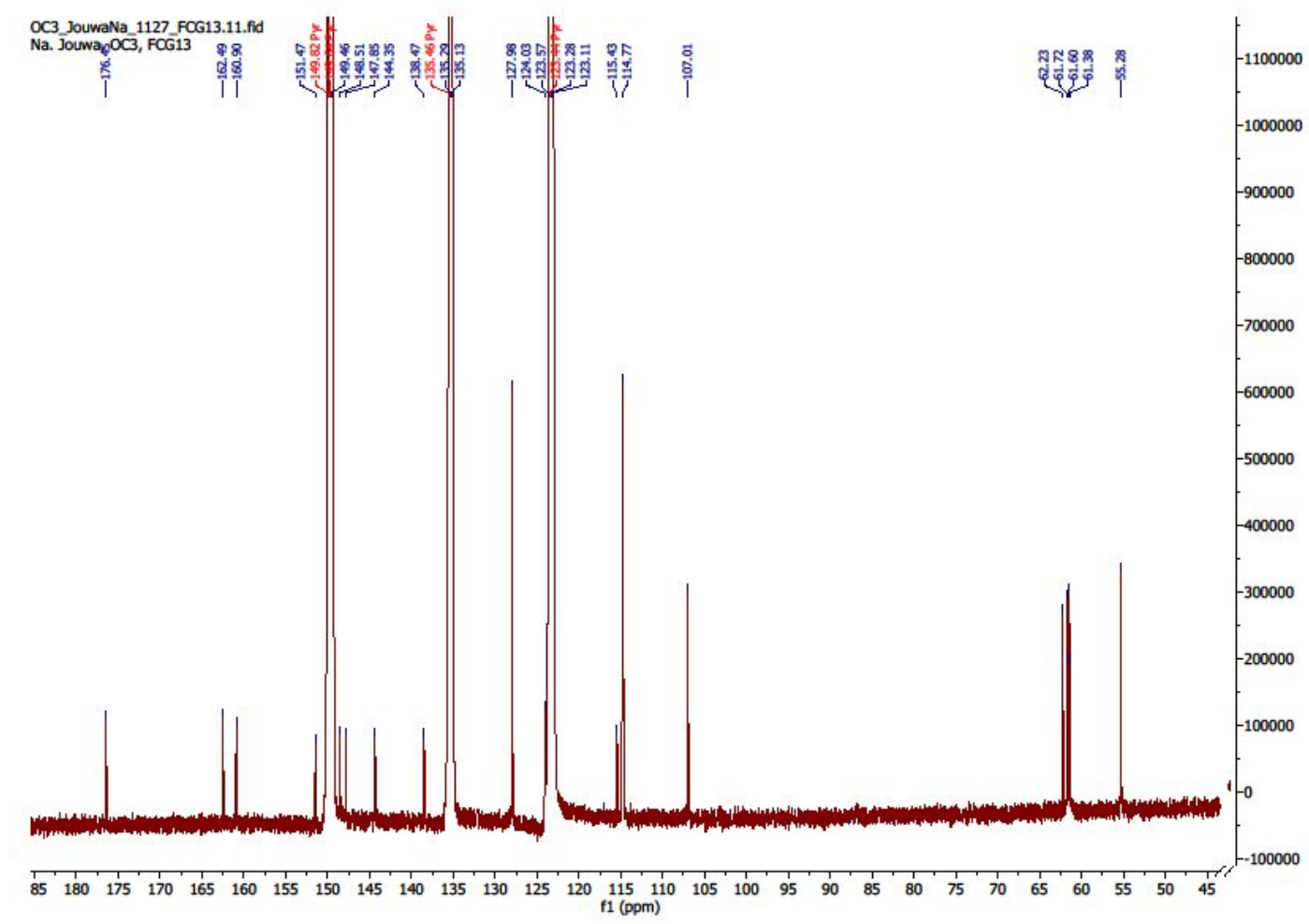

Figure S81: ${ }^{13} \mathrm{C}$ NMR Spectrum (125 MHz, Pyridin- $d_{5}$ ) of 5,6, 7,8,4'-Pentametoxyflavone (15)

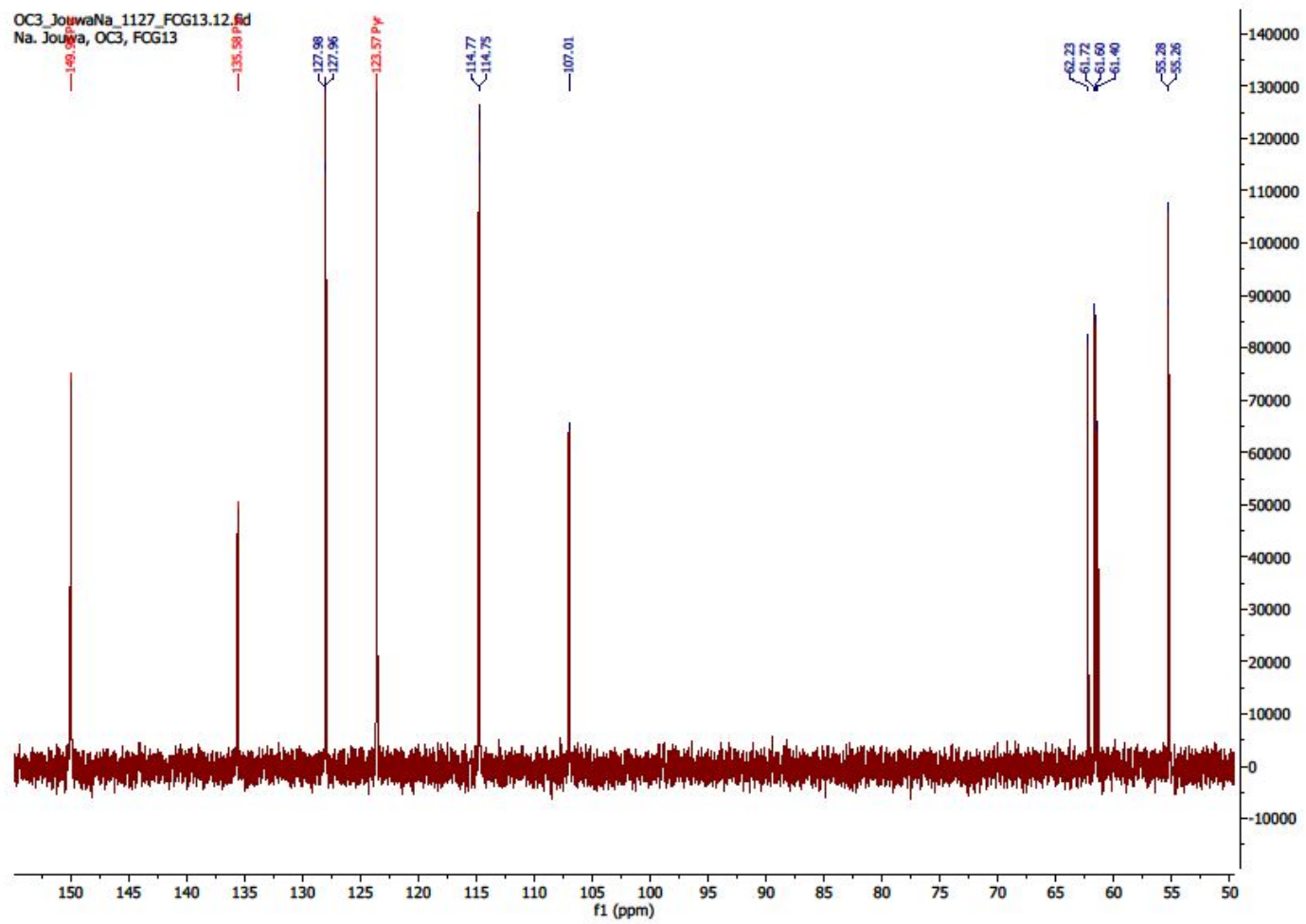

Figure S82: 135-DEPT Spectrum (125 MHz, Pyridin- $d_{5}$ ) of 5,6, 7,8,4'-Pentametoxyflavone (15) 
OC3_Chounale_0708_RCG12.10.fid

Je. Chouna, OCB, RCG12
PROTON Acetone \{C:1BrukerTToospin3.0\} Service 4

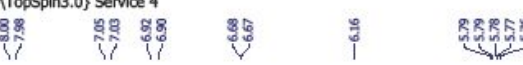

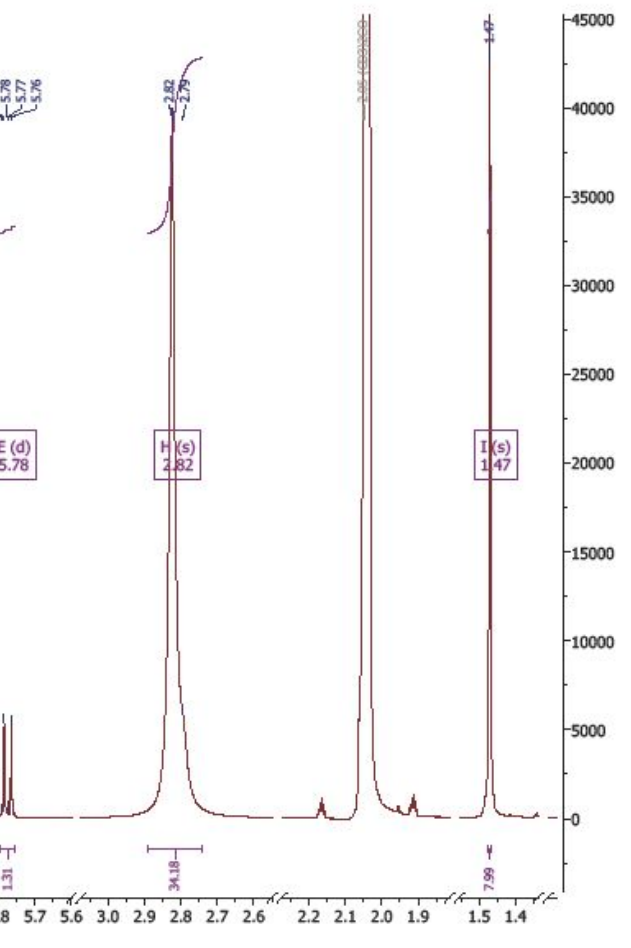

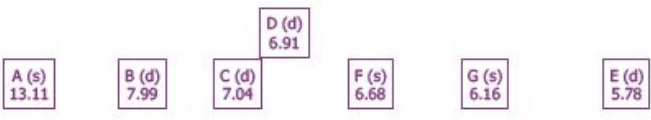

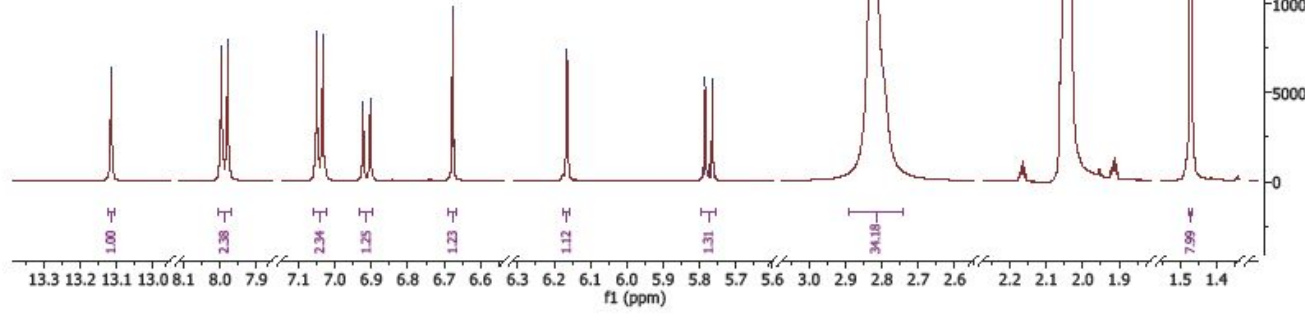

Figure S83: ${ }^{1} H$ NMR Spectrum $(500 \mathrm{MHz}$, Aceton-d $)$ of Atalantaflavone (17)

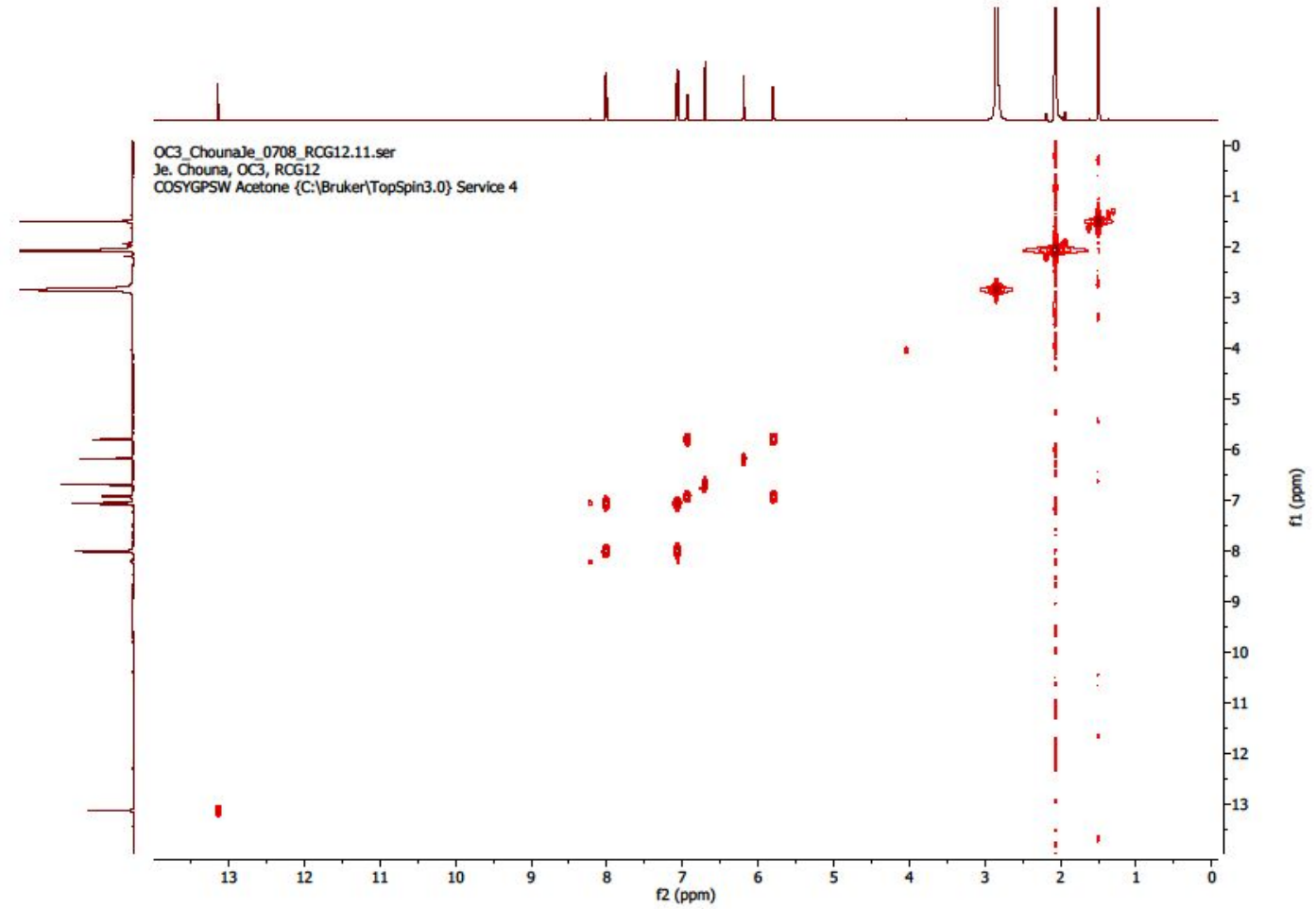

Figure S84: COSY Spectrum of Atalantaflavone (17) 


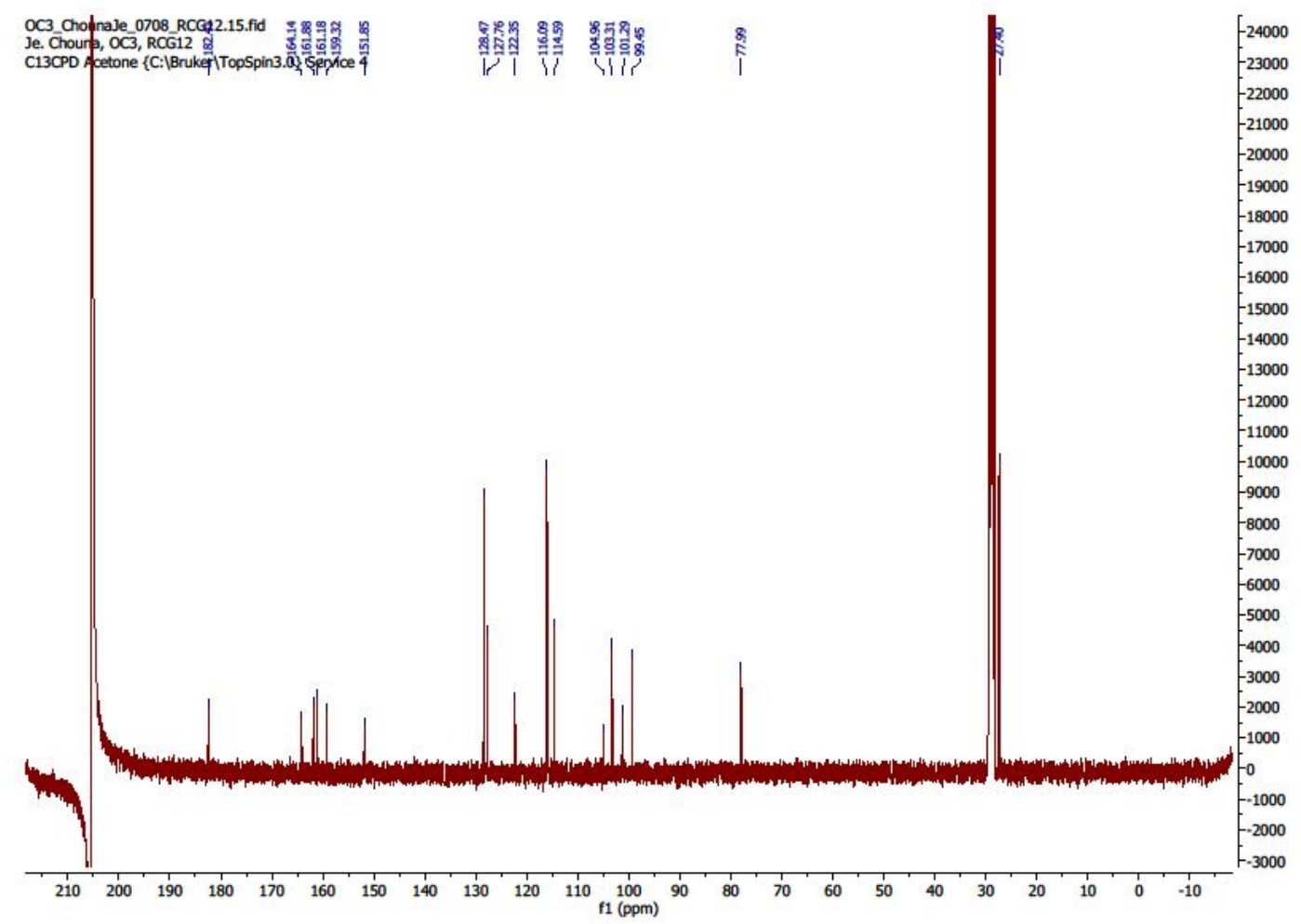

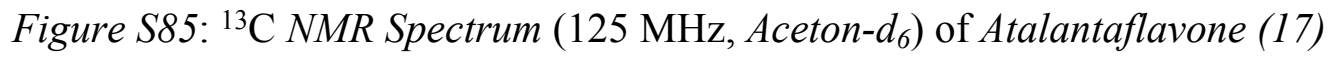

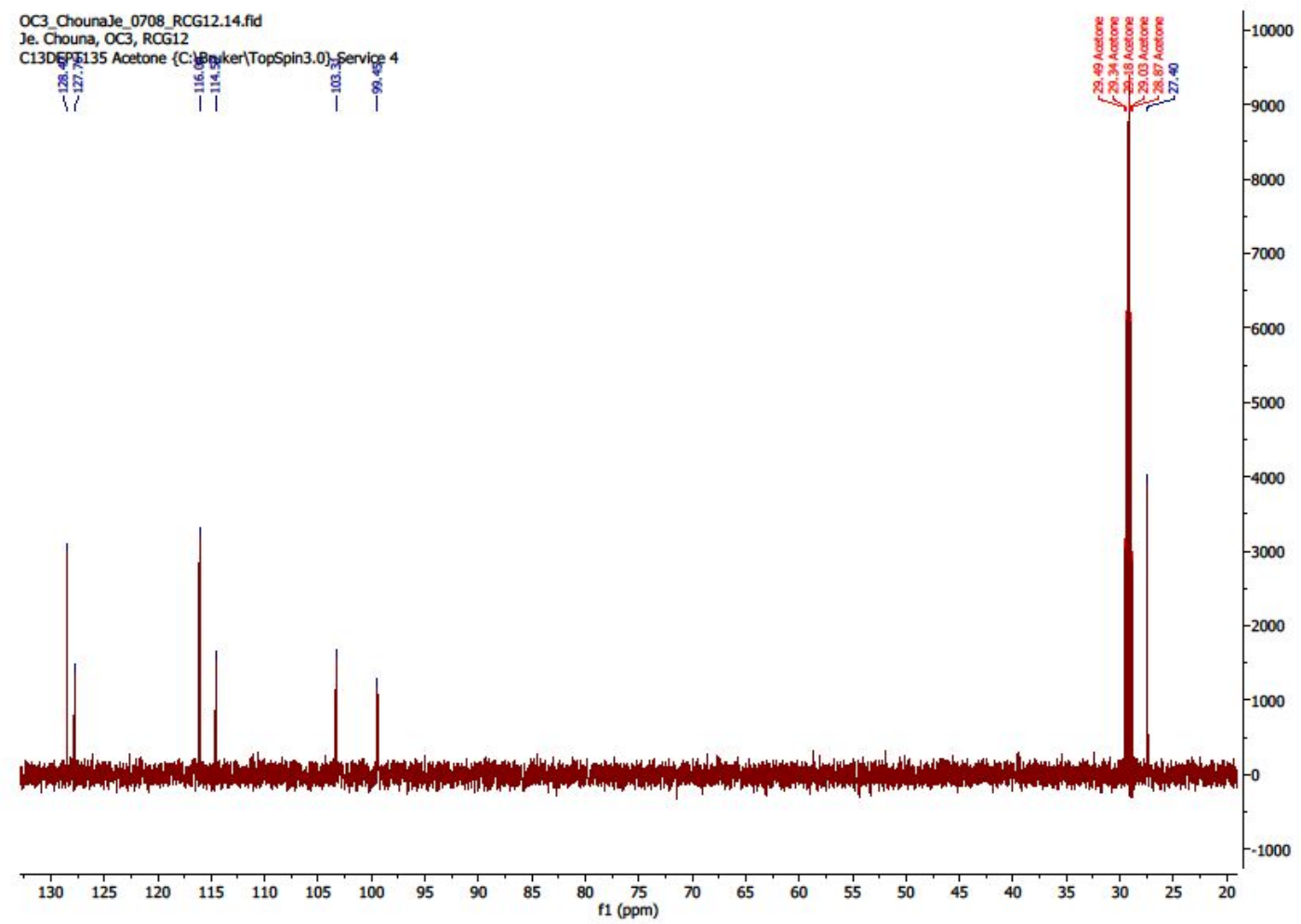

Figure S86: 135-DEPT Spectrum (125 MHz, Aceton-d $)_{6}$ of Atalantaflavone (17) 


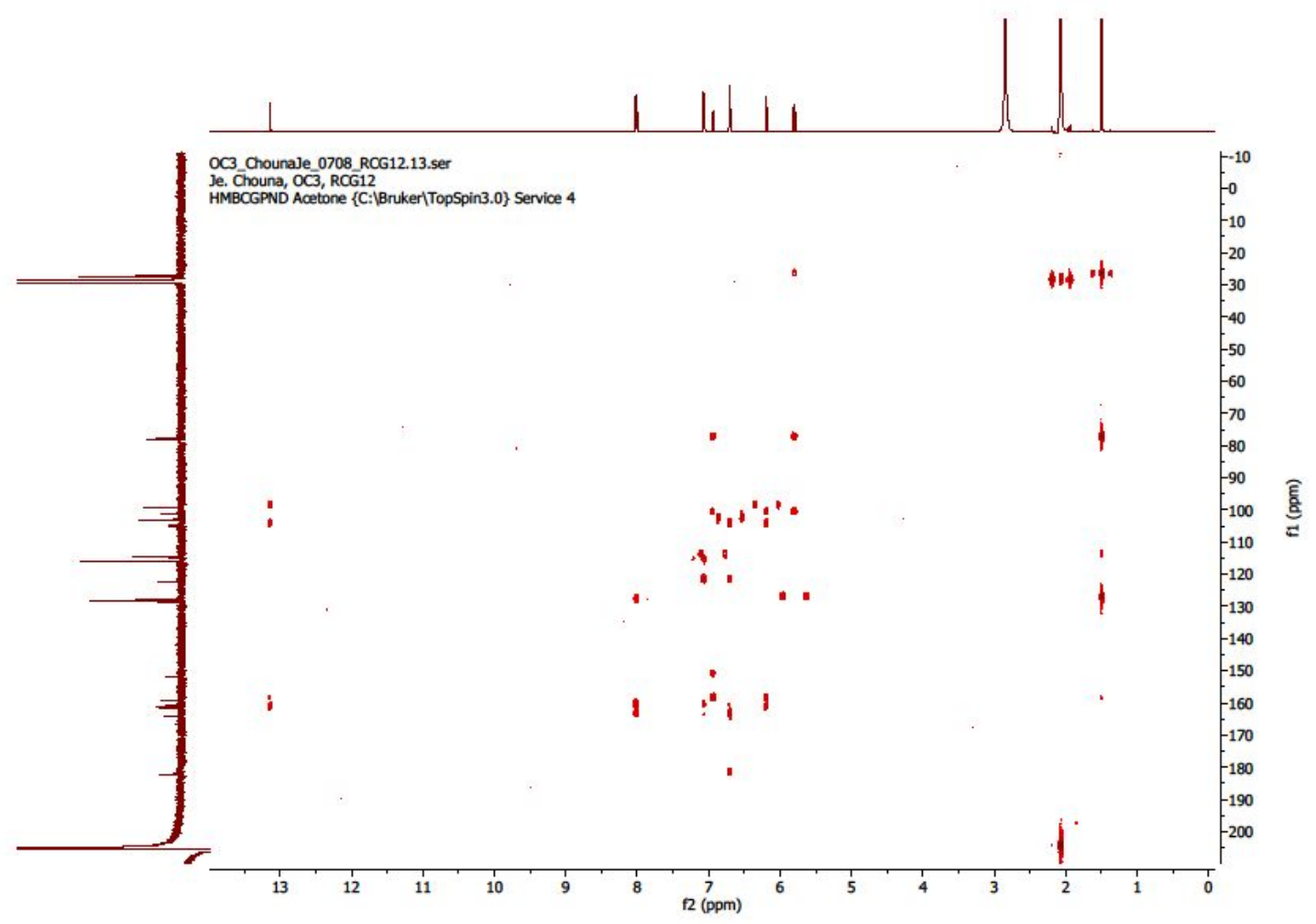

Figure S87: HMBC Spectrum of Atalantaflavone (17)

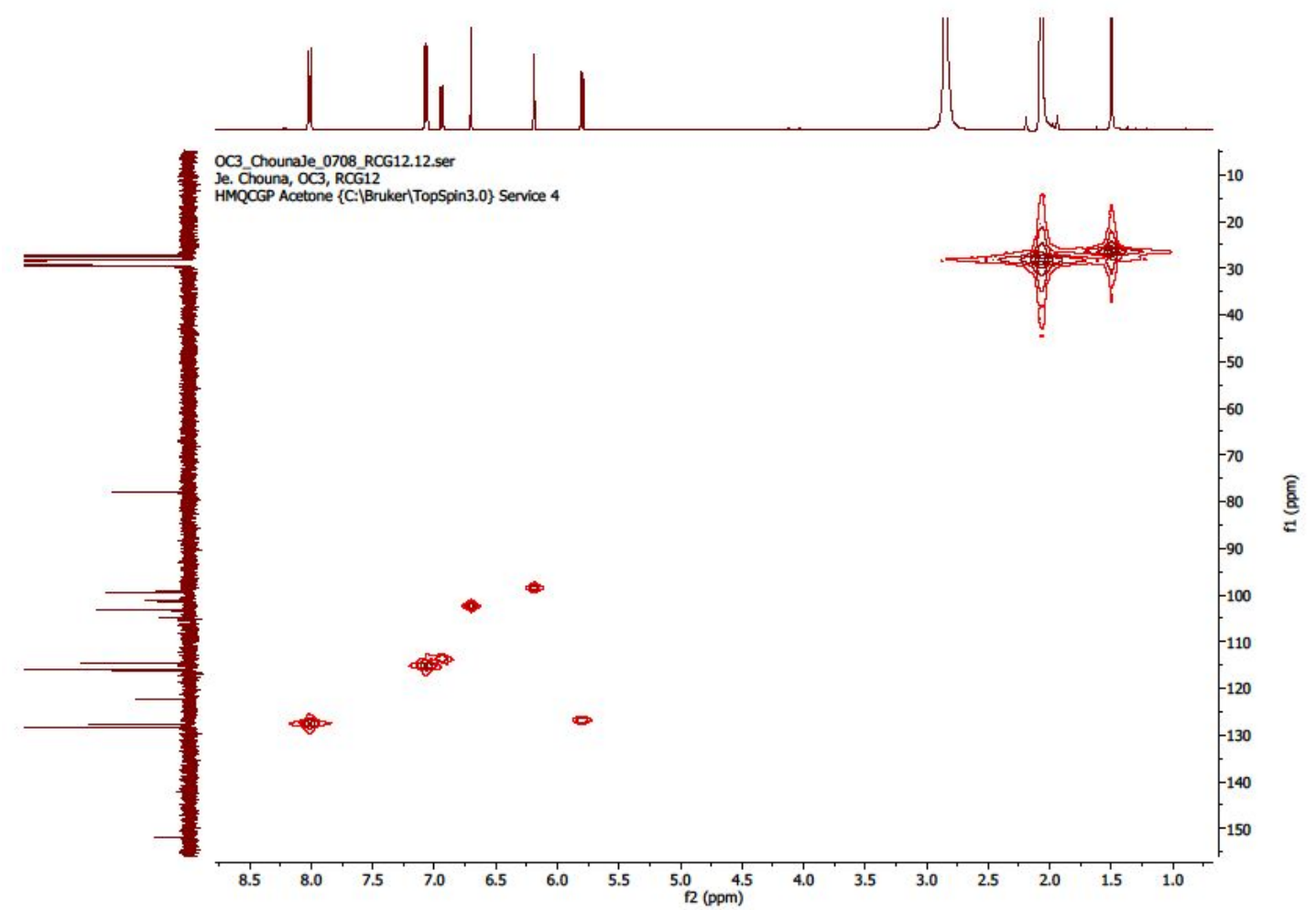

Figure S88: HSQC Spectrum of atalantaflavone (17) 


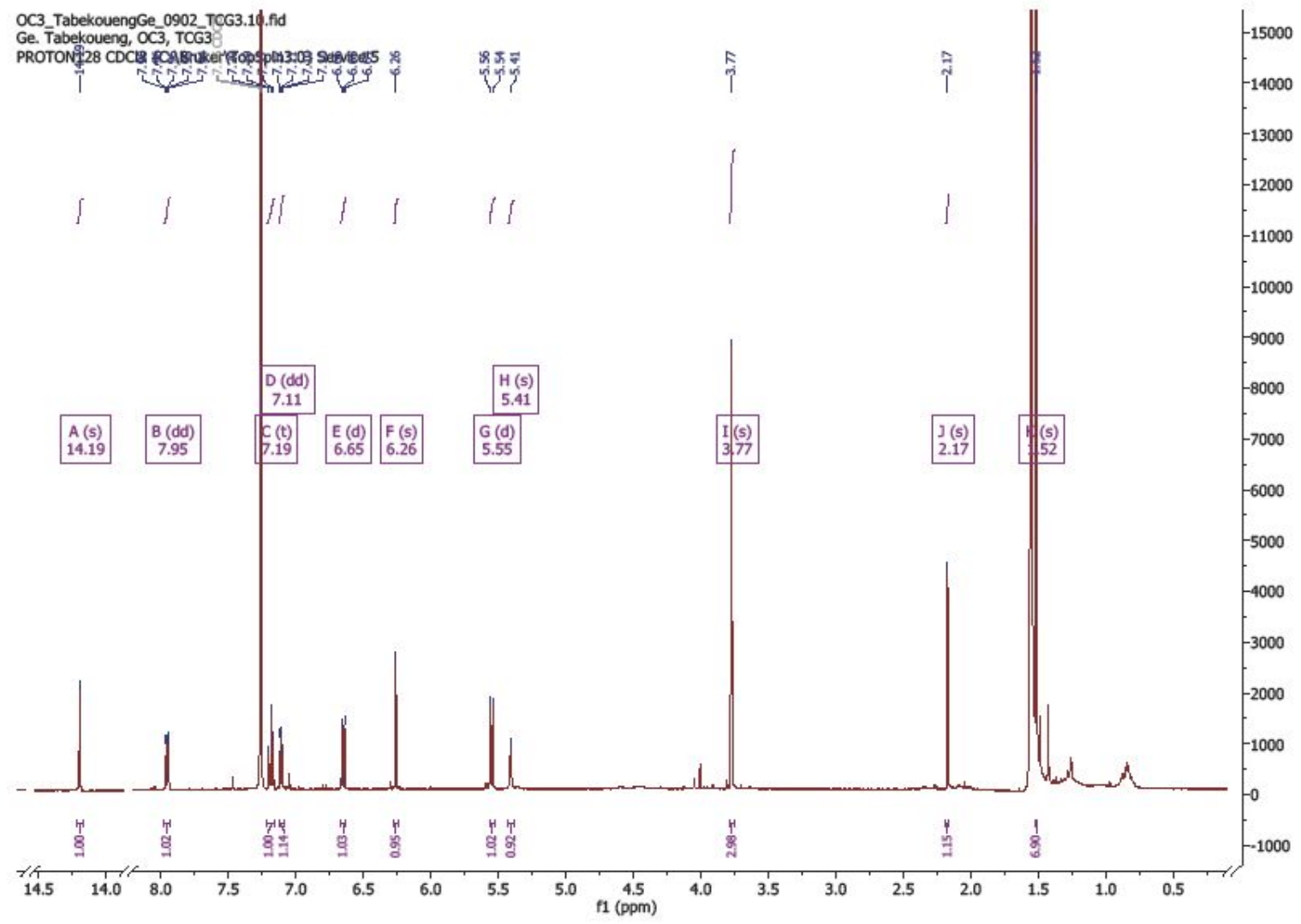

Figure S89: ${ }^{1} \mathrm{H} \mathrm{NMR}$ Spectrum (500 MHz, $\mathrm{CDCl}_{3}$ ) of 5-hydroxynoracronycine (18)

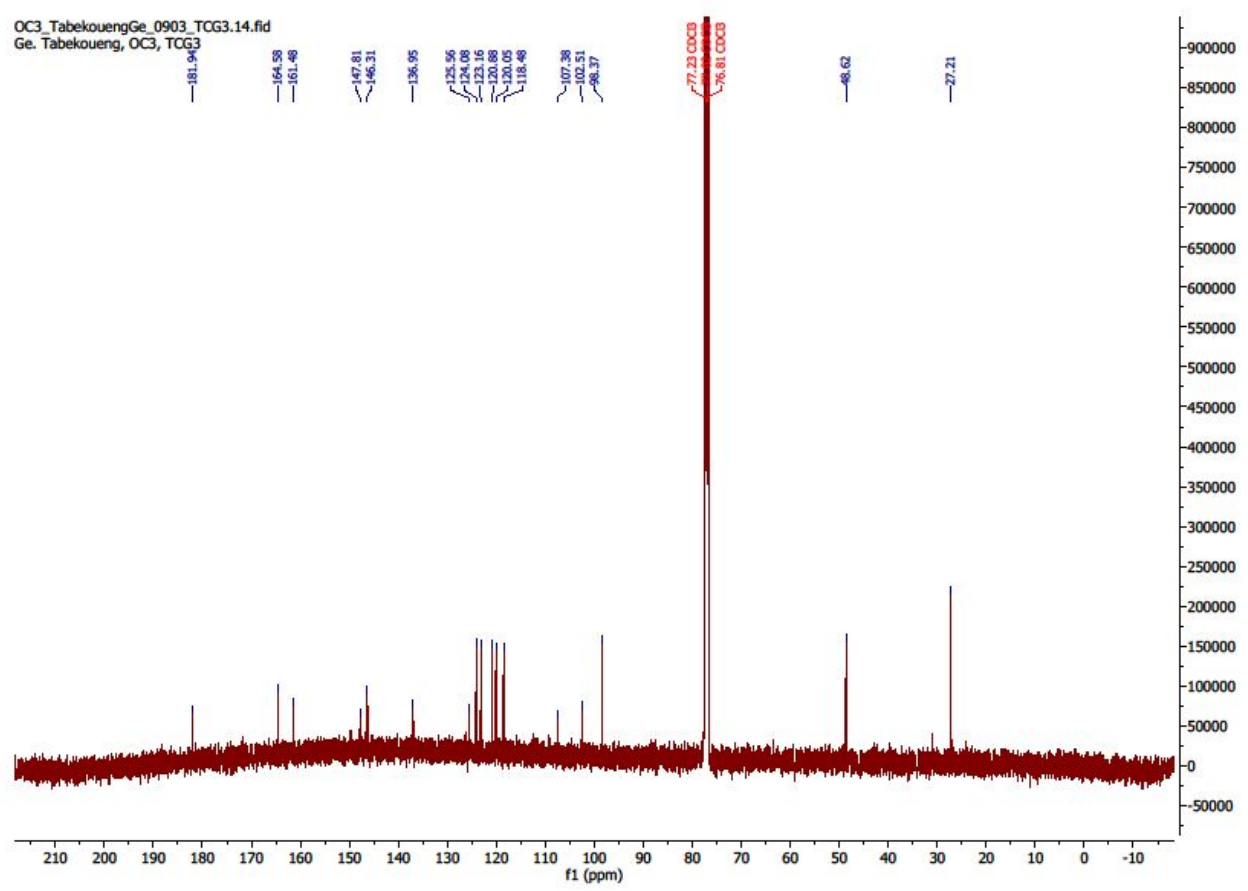

Figure S90: ${ }^{13} \mathrm{C}$ NMR Spectrum (125 MHz, $\mathrm{CDCl}_{3}$ ) of 5-hydroxynoracronycine (18) 


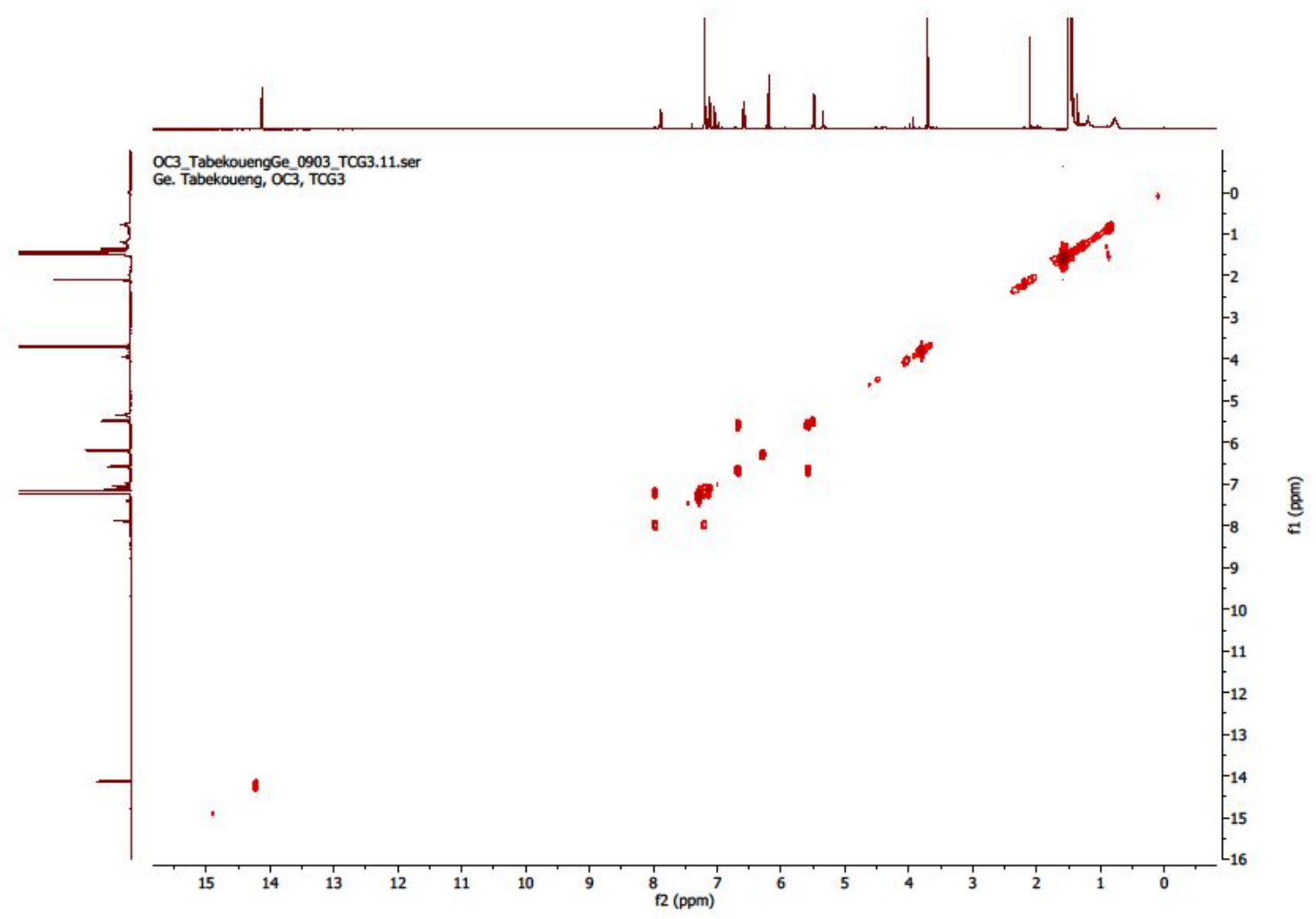

Figure S91: COSY Spectrum of 5-hydroxynoracronycine (18)

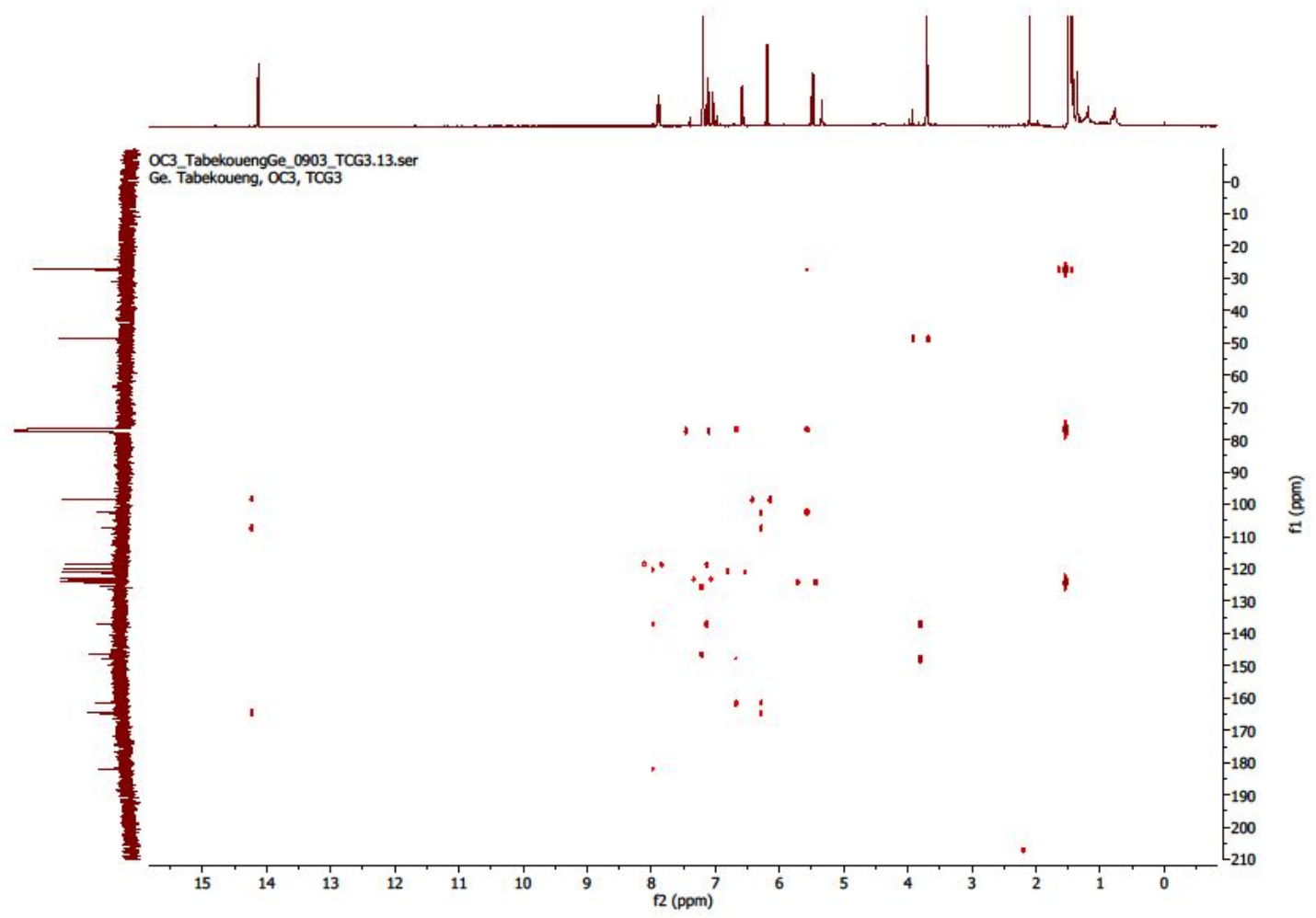

Figure S92: HMBC Spectrum of 5-hydroxynoracronycine (18) 


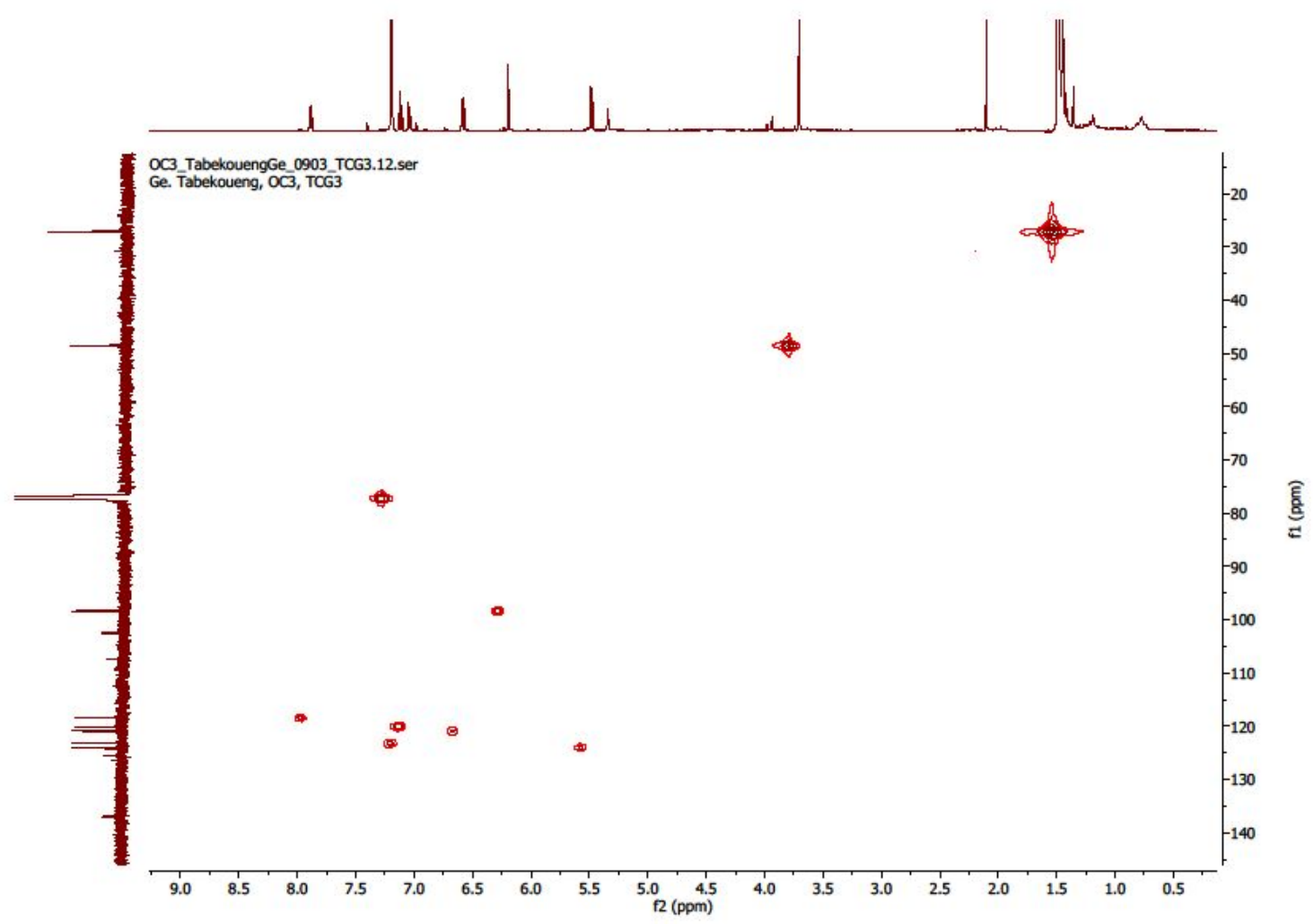

Figure S93: HSQC Spectrum of 5-hydroxynoracronycine (18)

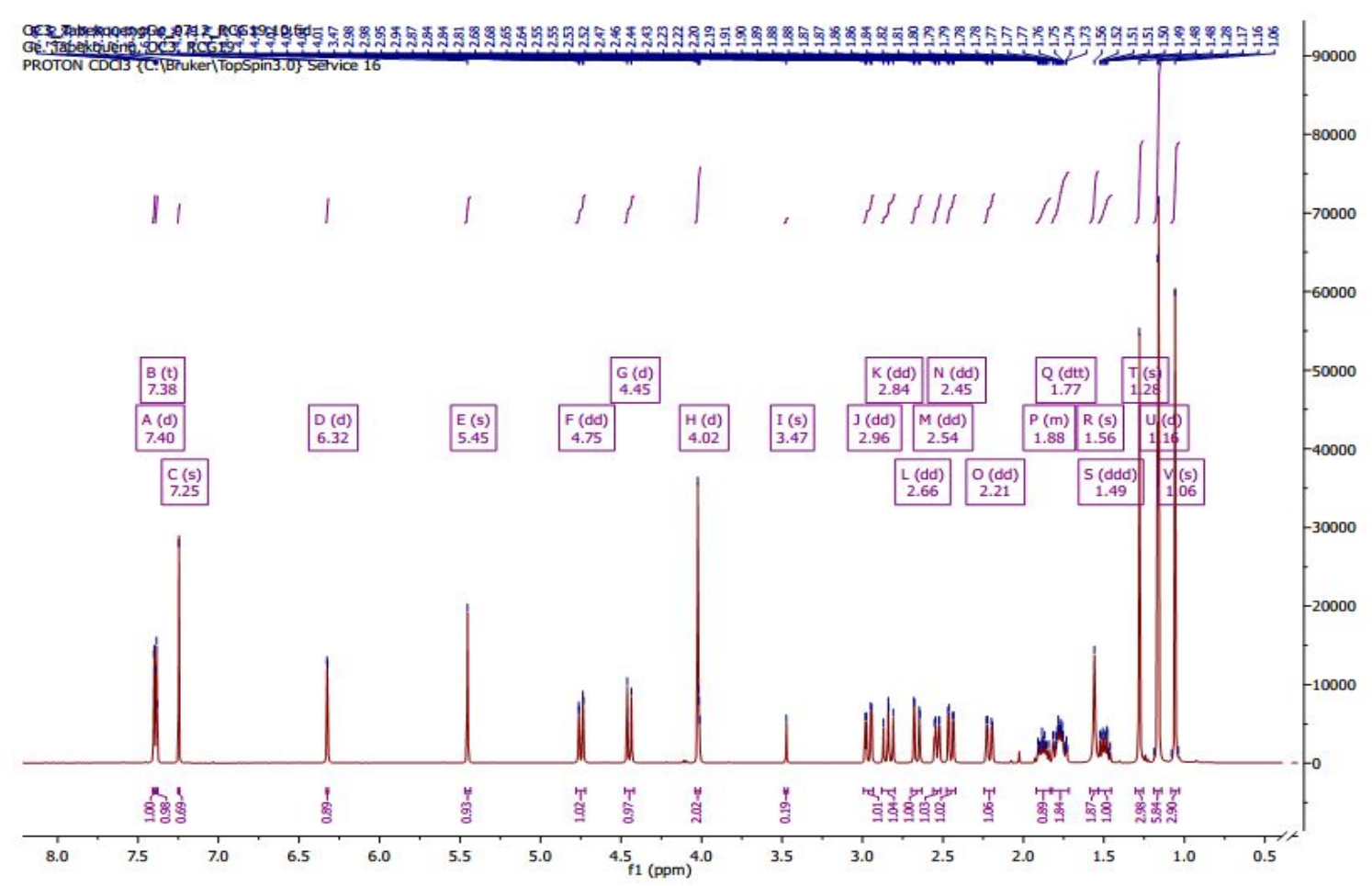

Figure S94: ${ }^{1} \mathrm{H}$ NMR Spectrum $\left(500 \mathrm{MHz}, \mathrm{CDCl}_{3}\right)$ of limonin (19) 


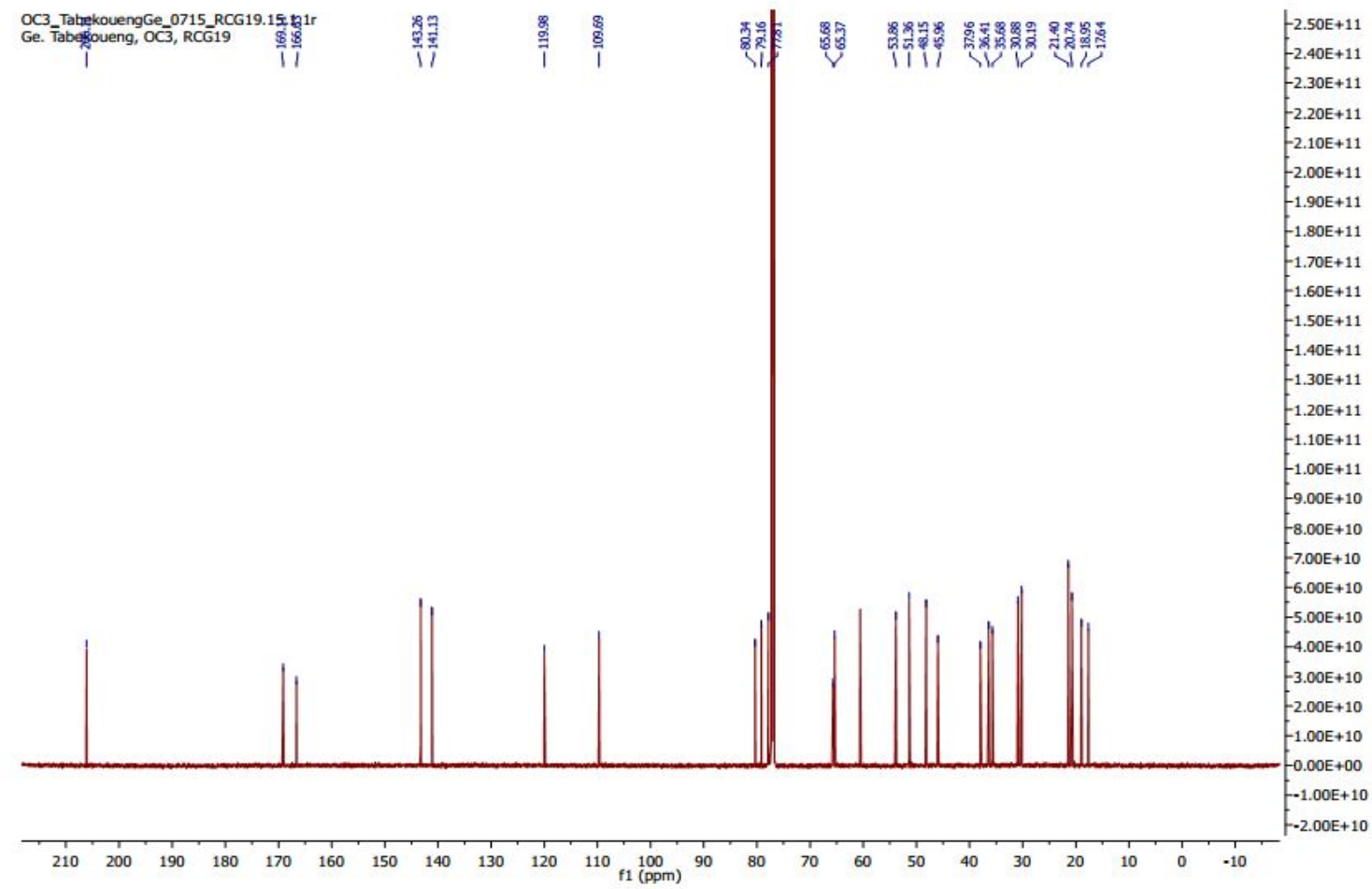

Figure S95: ${ }^{13} \mathrm{C}$ NMR Spectrum $\left(125 \mathrm{MHz}, \mathrm{CDCl}_{3}\right)$ of limonin (19)

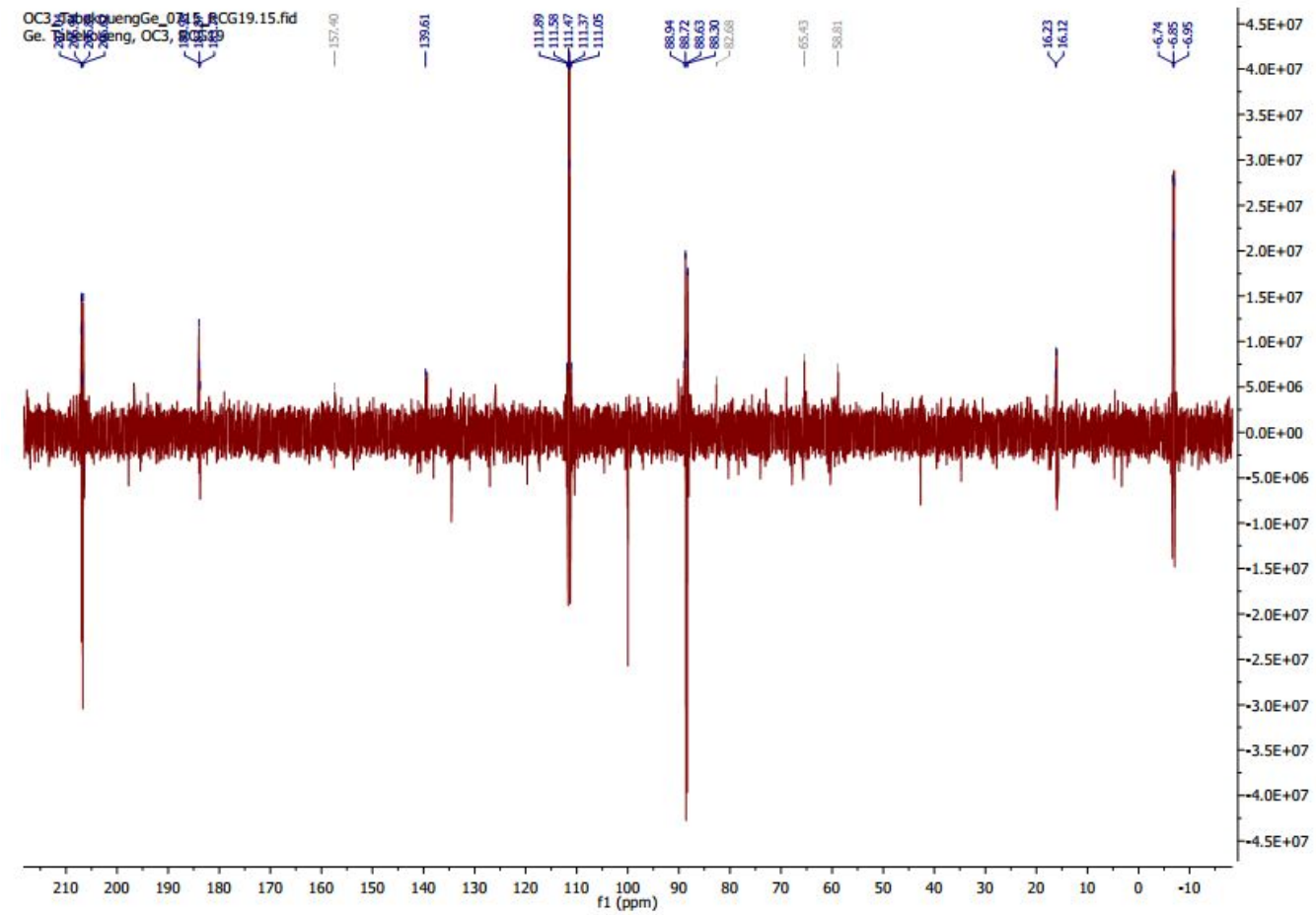

Figure S96: 135-DEPT Spectrum (125 MHz, $\mathrm{CDCl}_{3}$ ) of limonin (19) 


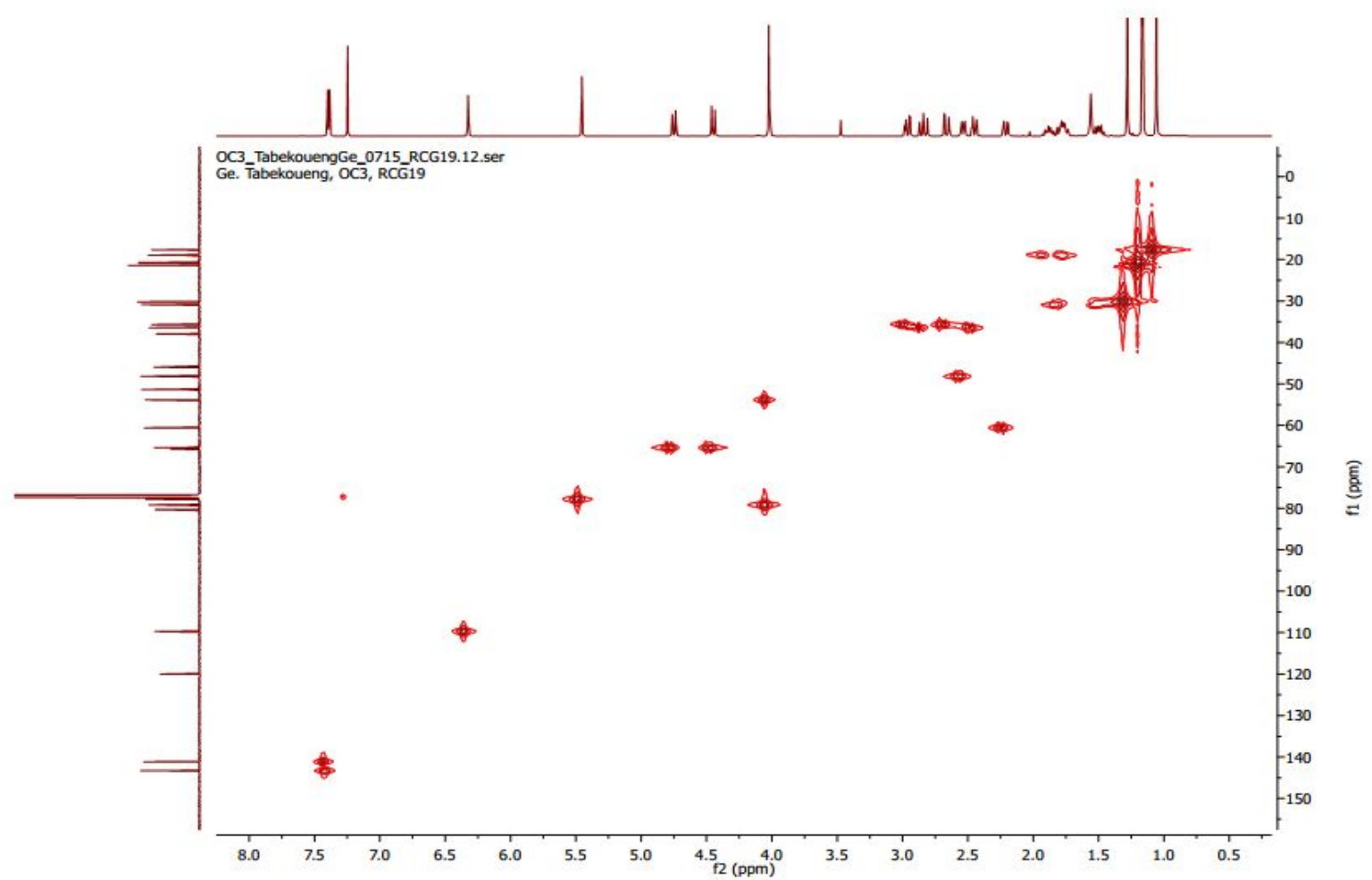

Figure S97: HSQC Spectrum of limonin (19)

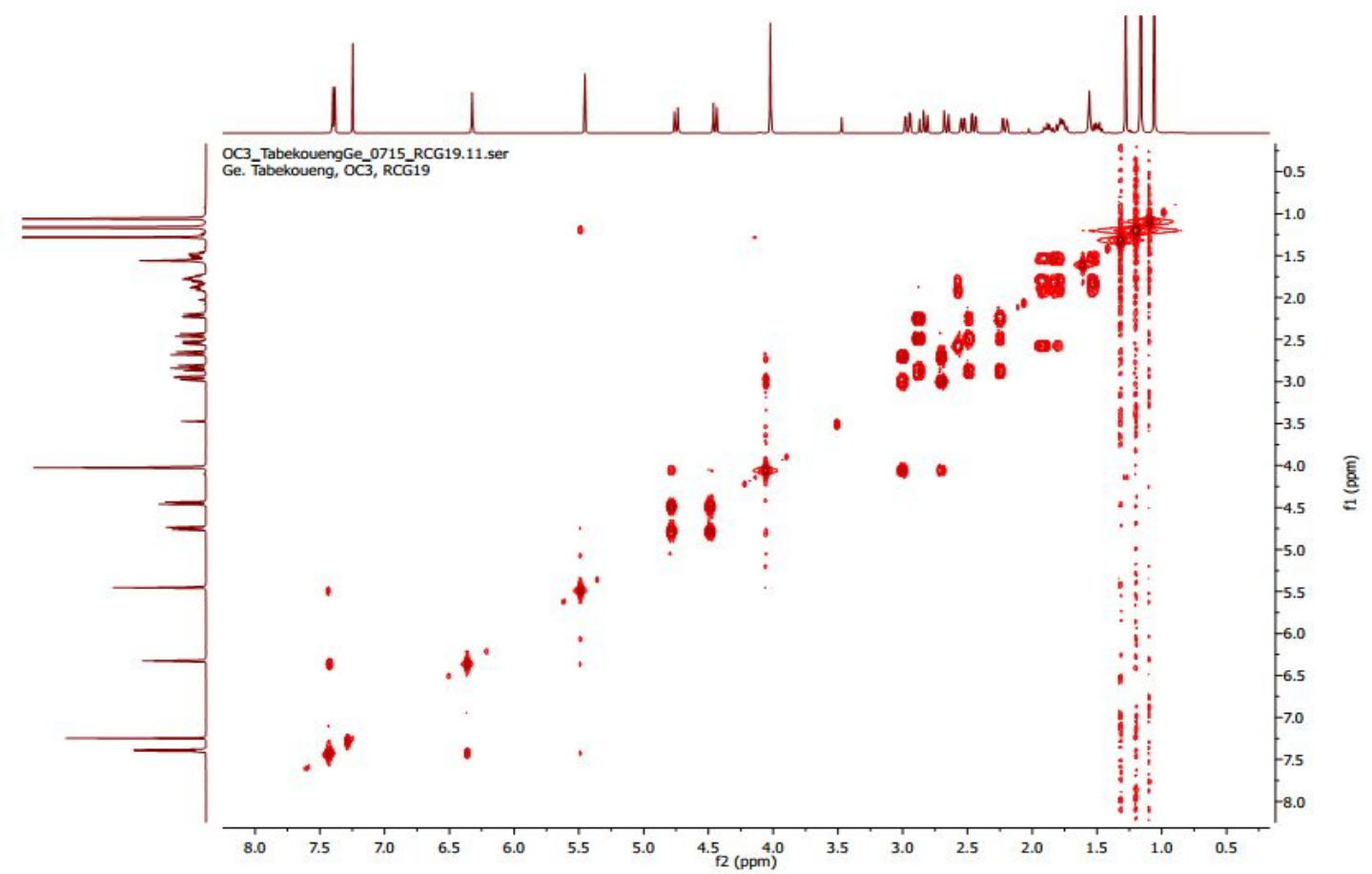

Figure S98: COSY Spectrum of limonin (19) 


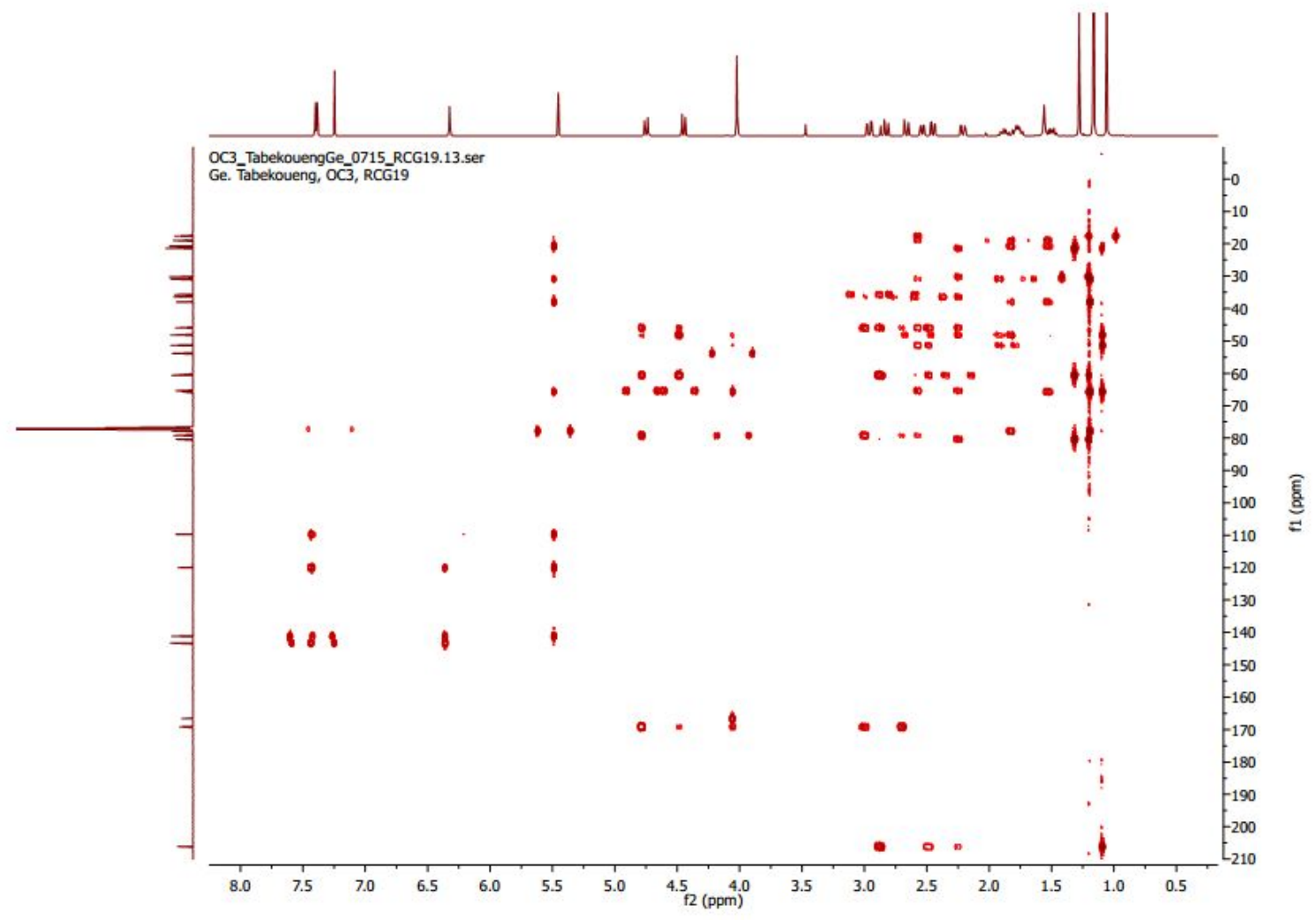

Figure S99: HMBC Spectrum of limonin (19)

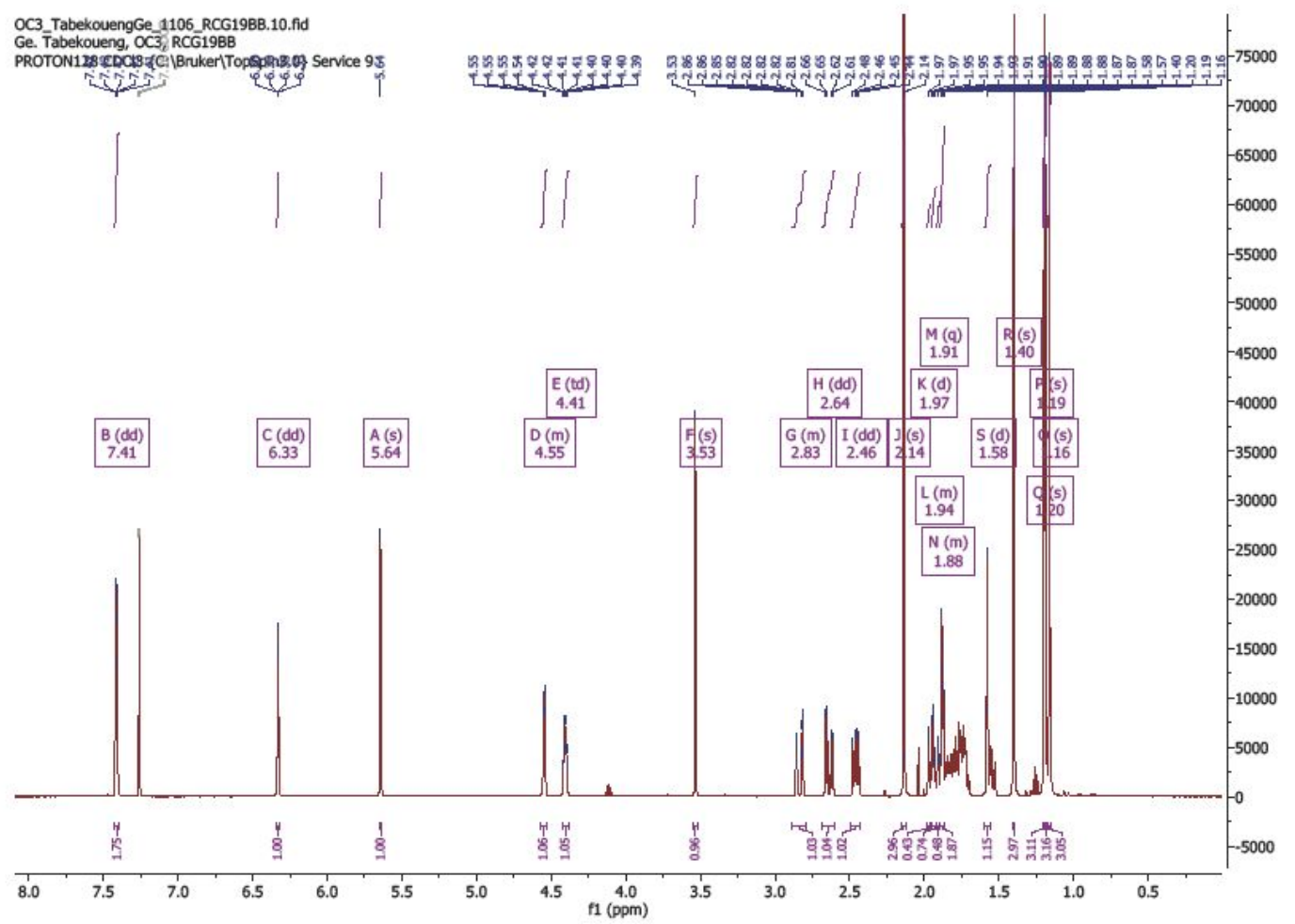

Figure S100: ${ }^{1} \mathrm{H}$ NMR Spectrum (500 MHz, $\left.C D C l_{3}\right)$ of 1-(10-19) abeo-7 $\alpha$-Acetoxy-10 $\beta$ hydroxyisoobacunoic acid-3, 10-lactone (20) 


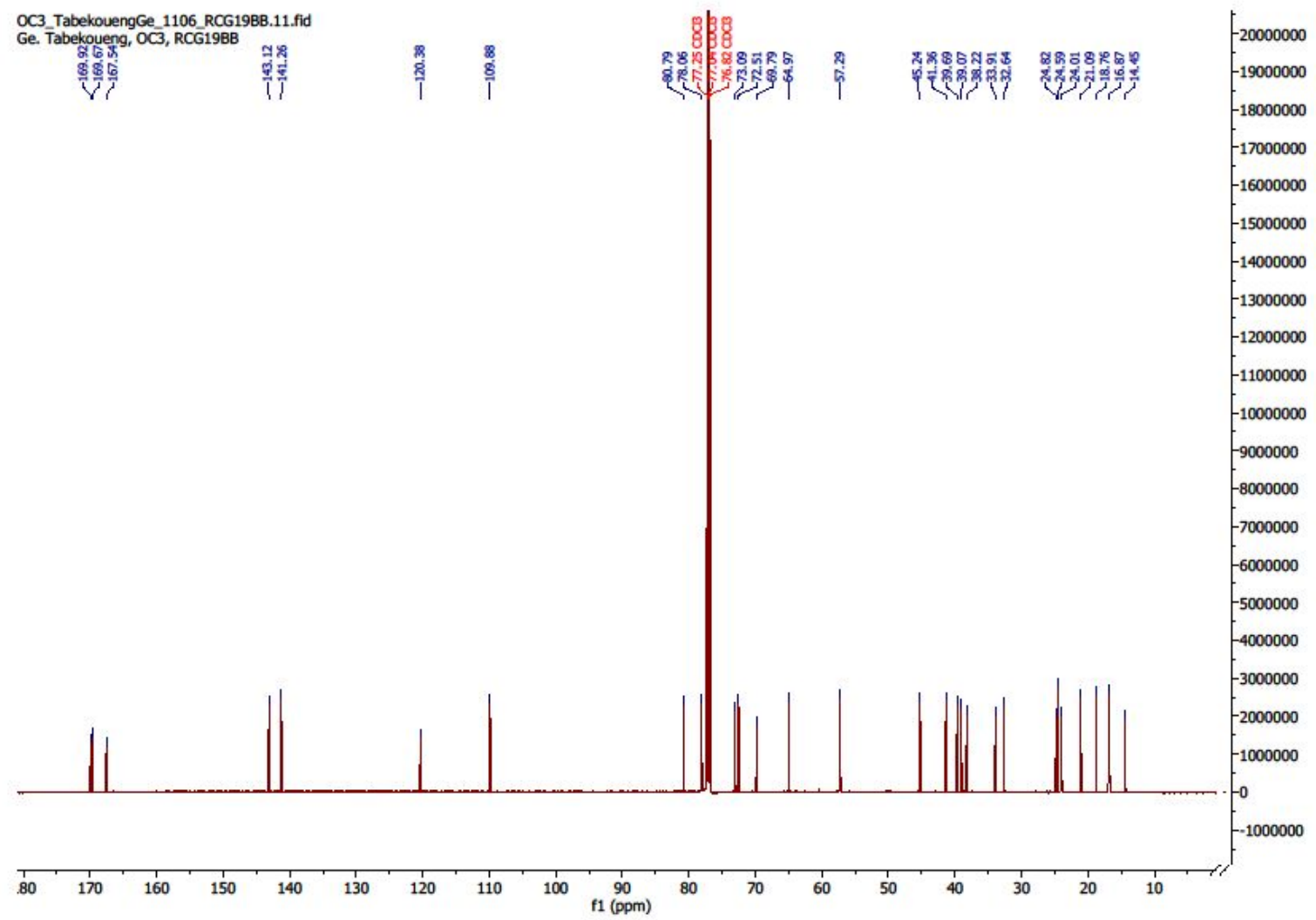

Figure S101: ${ }^{13} \mathrm{C}$ NMR Spectrum $\left(125 \mathrm{MHz}, C D C l_{3}\right)$ of 1-(10-19) abeo-7 $\alpha$-Acetoxy-10 $\beta$ hydroxyisoobacunoic acid-3, 10-lactone (20)

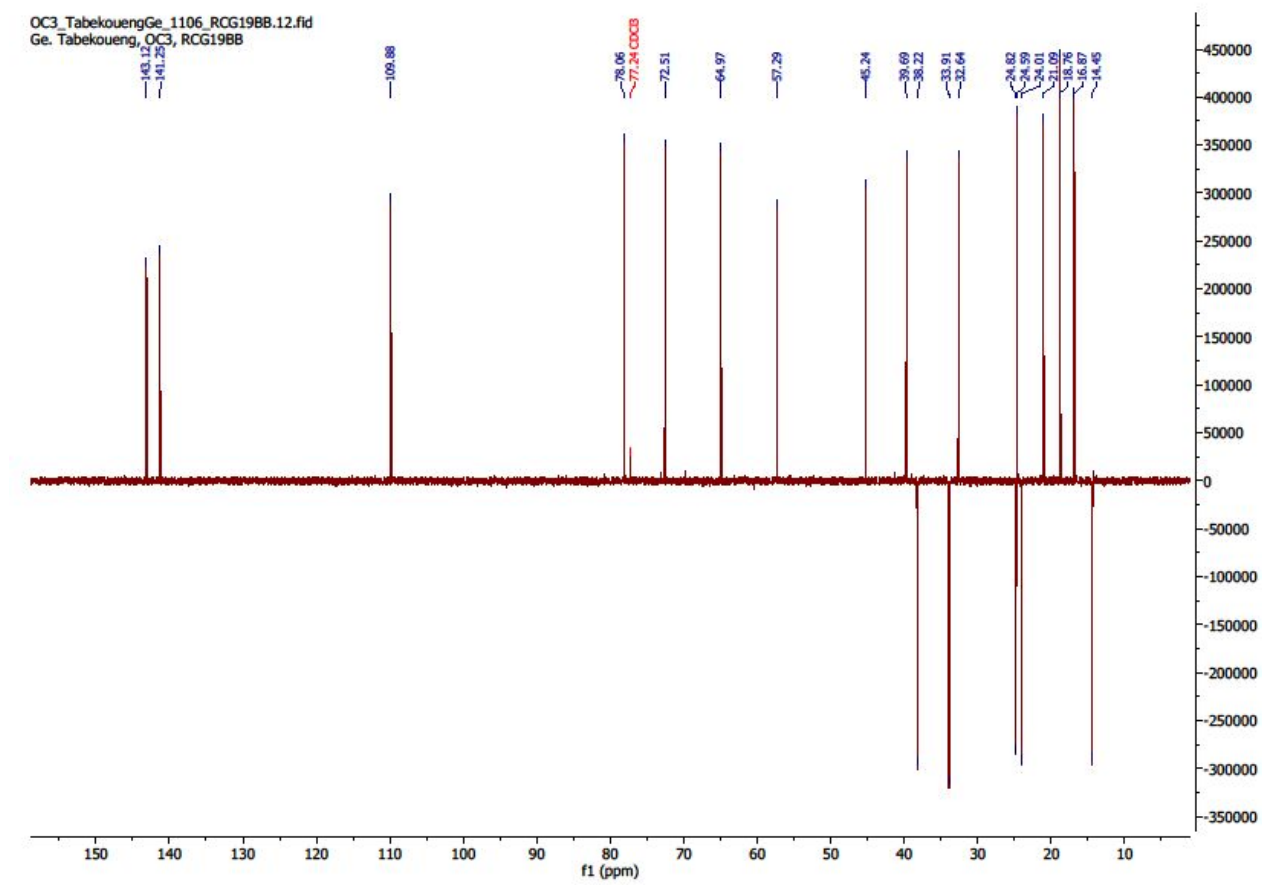

Figure S102: 135-DEPT Spectrum (125 MHz, $\left.C D C l_{3}\right)$ of 1-(10-19) abeo-7 $\alpha$-Acetoxy-10 $\beta$ hydroxyisoobacunoic acid-3, 10-lactone (20) 


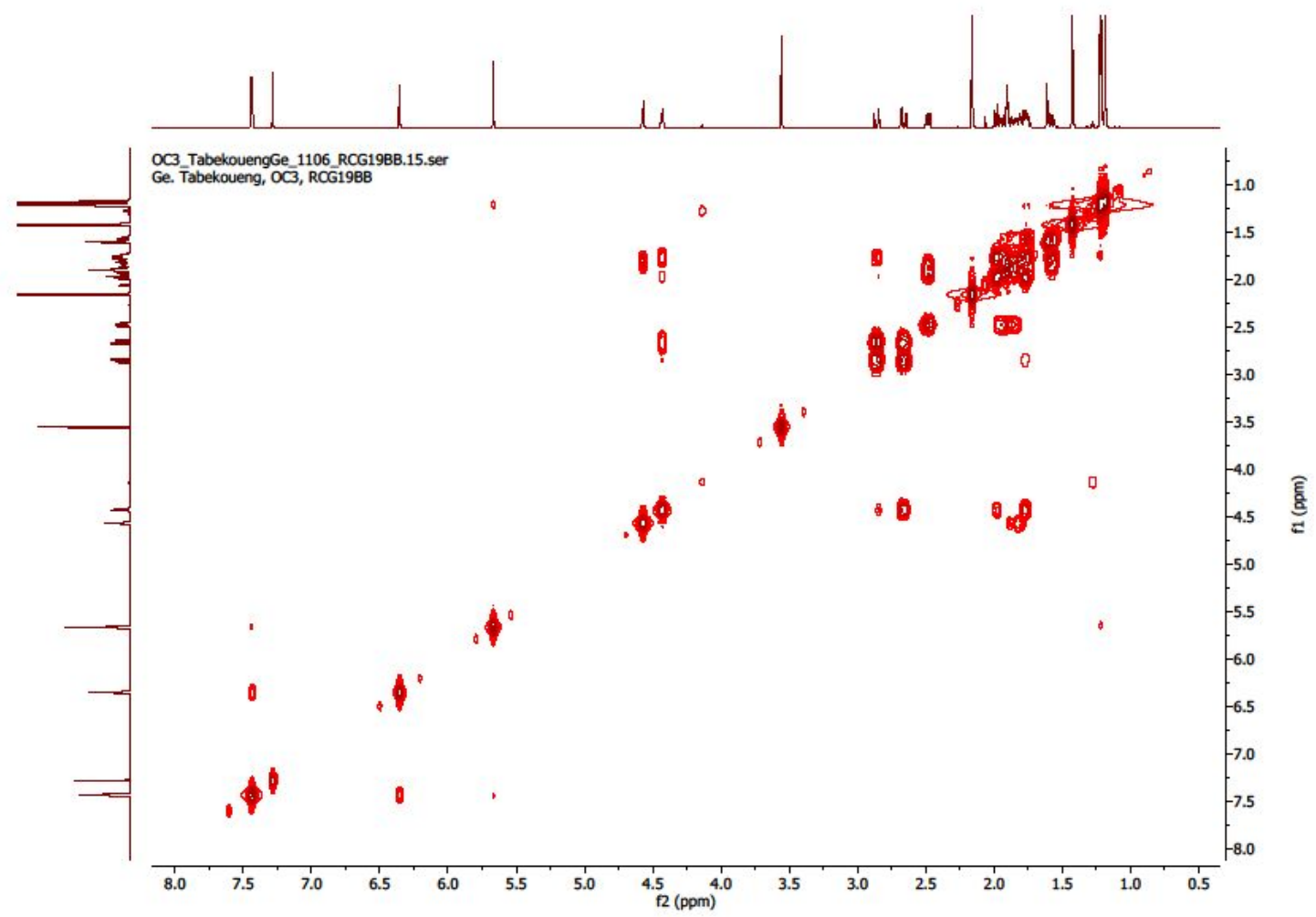

Figure S103: COSY Spectrum of 1-(10-19) abeo-7 $\alpha$-Acetoxy-10 $\beta$-hydroxyisoobacunoic acid3, 10-lactone (20)

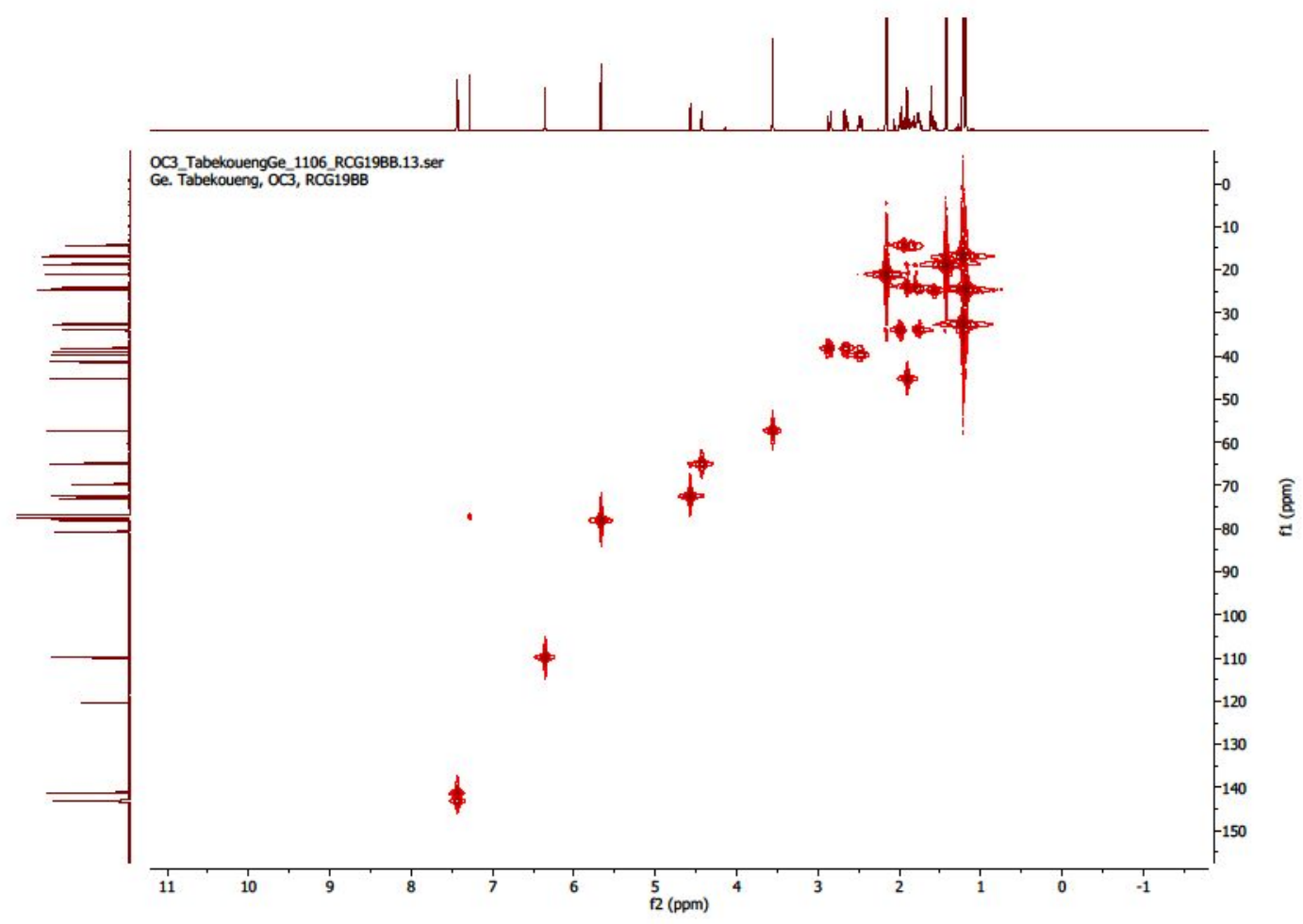

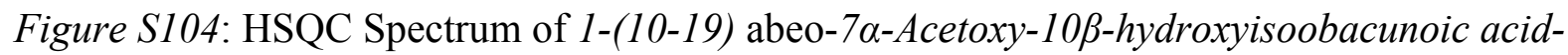
3, 10-lactone (20) 


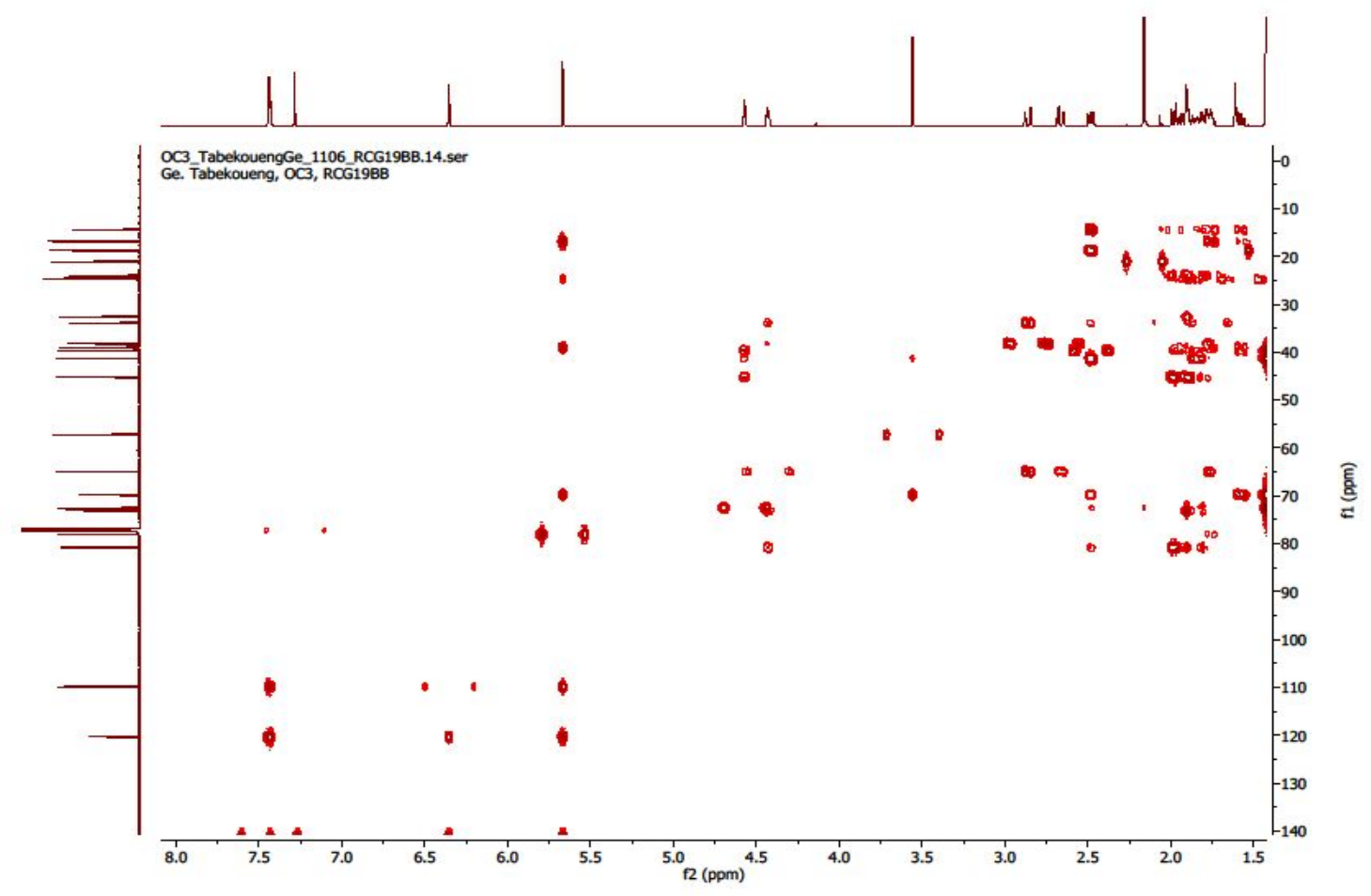

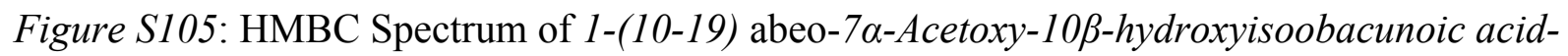
3, 10-lactone (20)

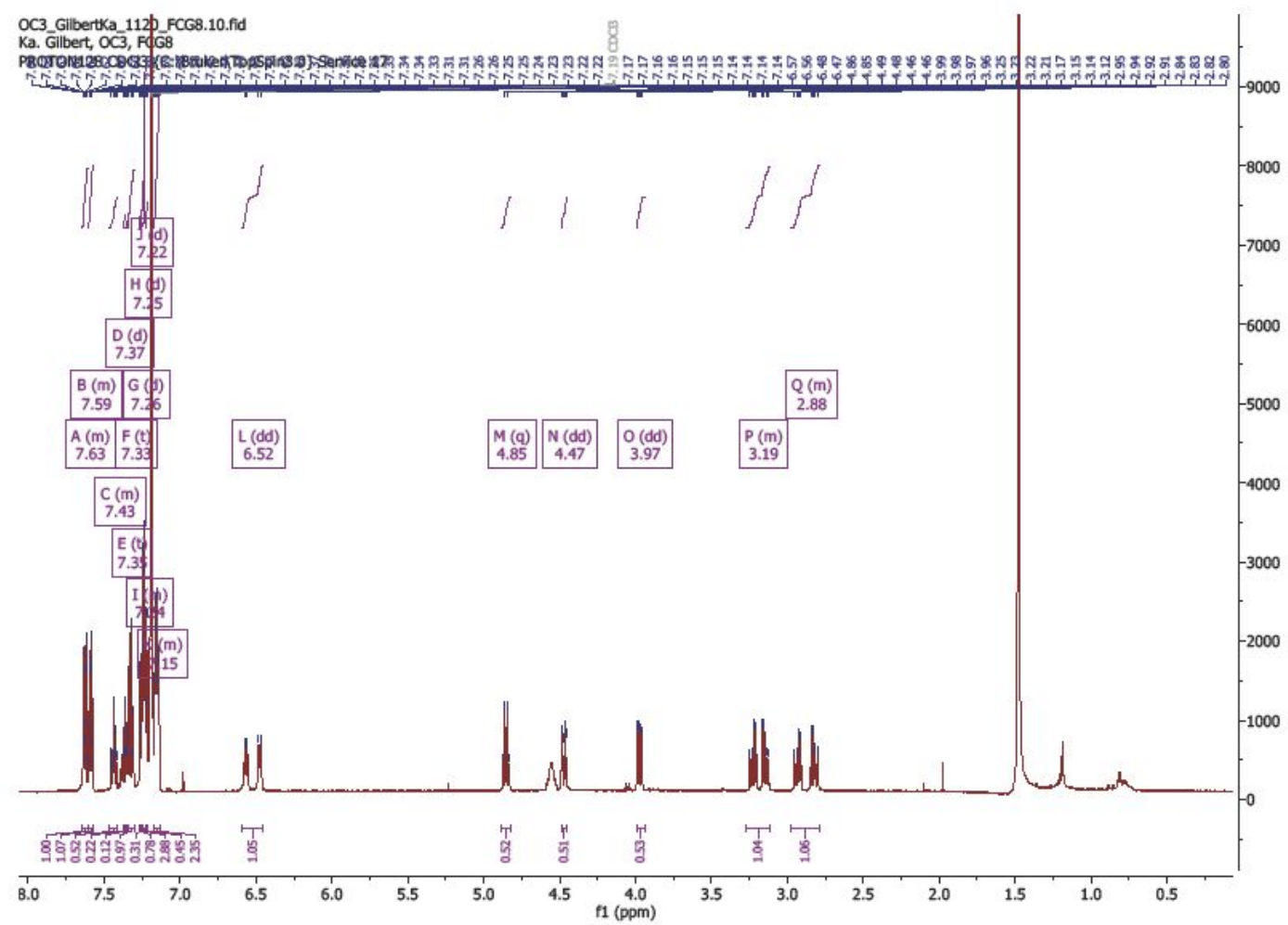

Figure S106: ${ }^{1} \mathrm{H}$ NMR Spectrum (500 MHz, $\left.C D C l_{3}\right)$ of Asperfenamate (21) 


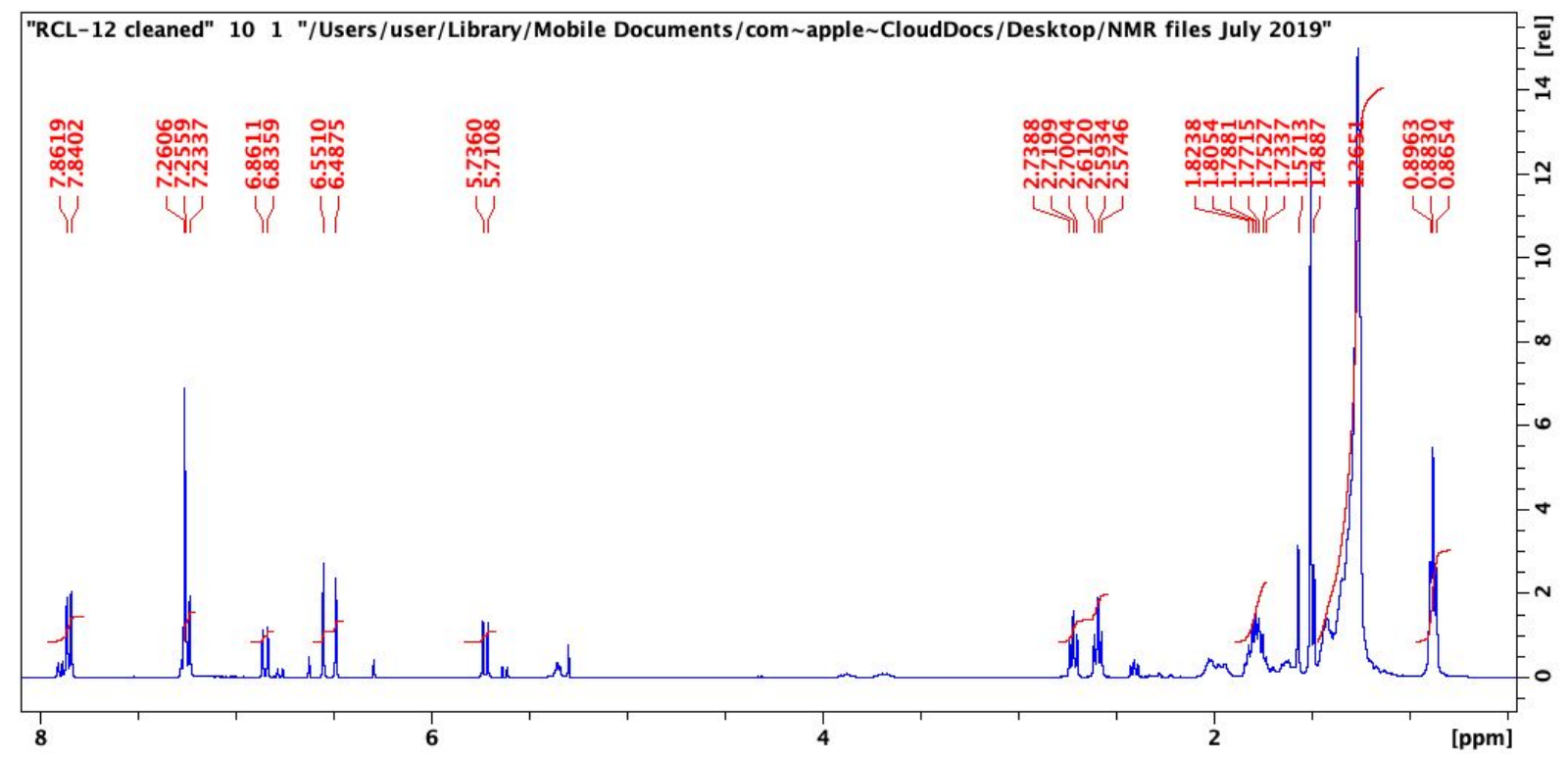

Figure S107: ${ }^{1} \mathrm{H}$ NMR spectrum (400 MHz, $C D C l$ ) for $16 a$

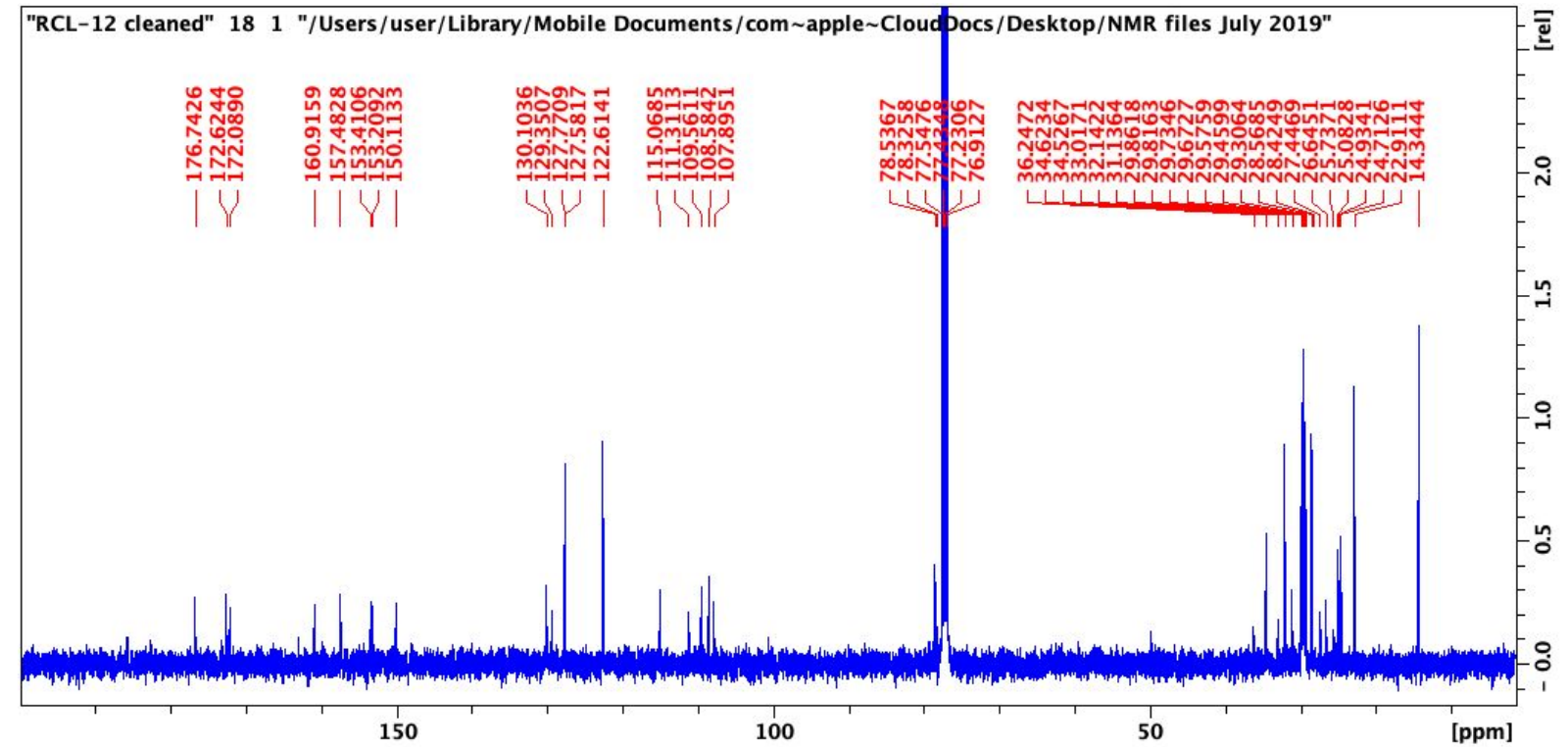

Figure S108: ${ }^{13} \mathrm{C}$ NMR spectrum $\left(400 \mathrm{MHz}, \mathrm{CDCl}_{3}\right)$ for 16 a 


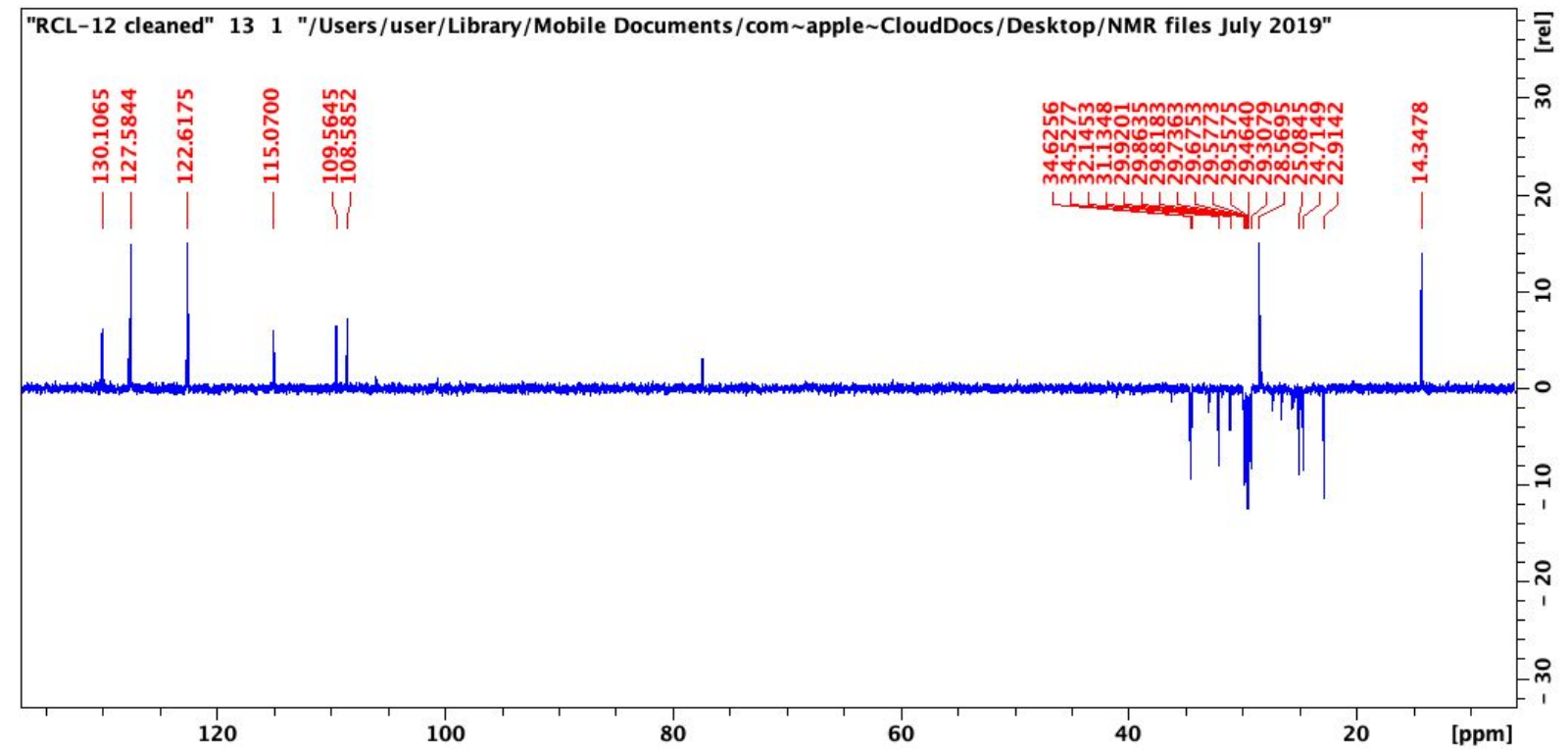

Figure S109: DEPT spectrum (400 MHz, $C D C l_{3}$ ) for $16 a$

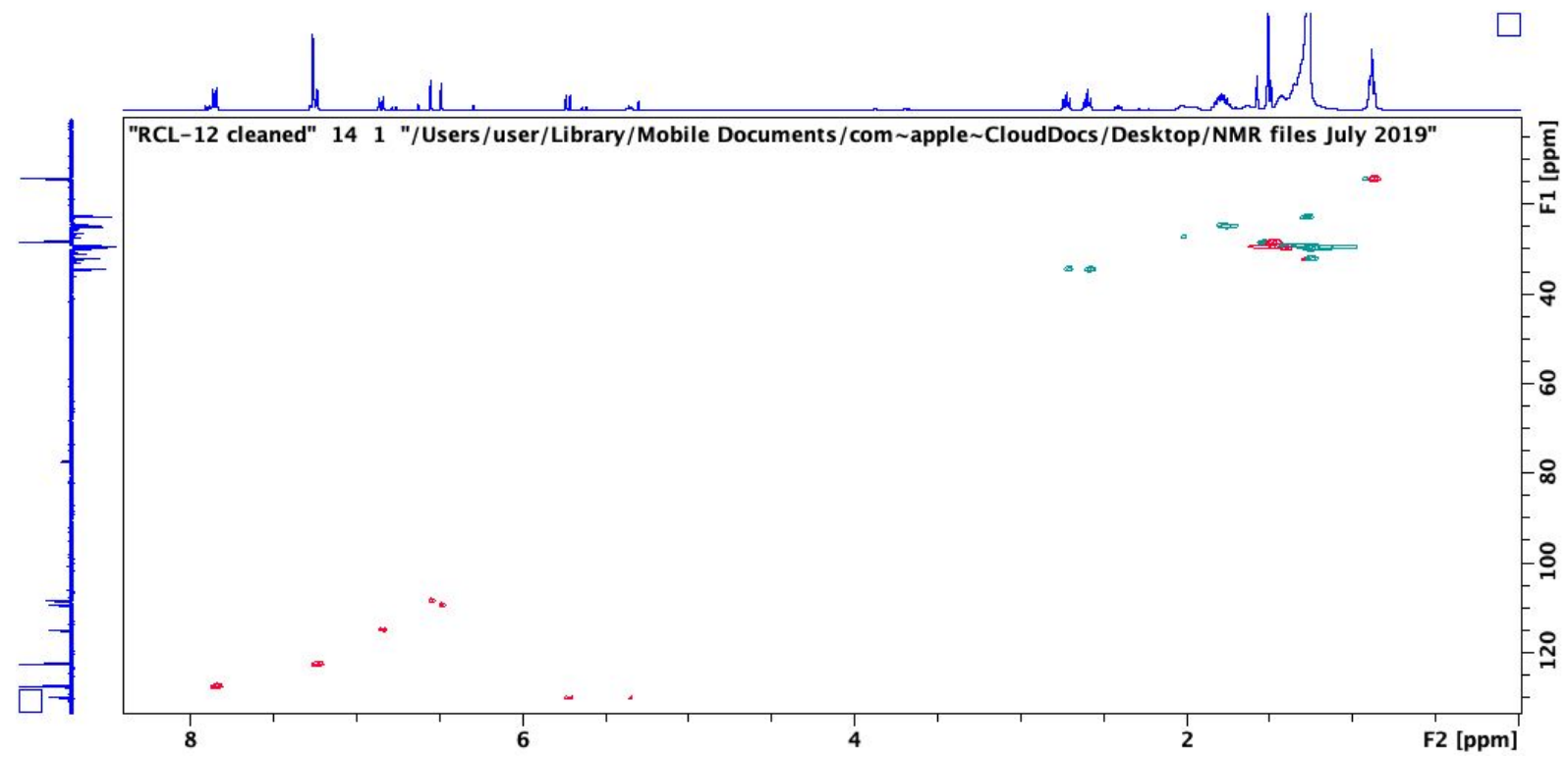

Figure S1 10: HSQCDEPT spectrum (400 MHz, $C D C l_{3}$ ) for 16 a 


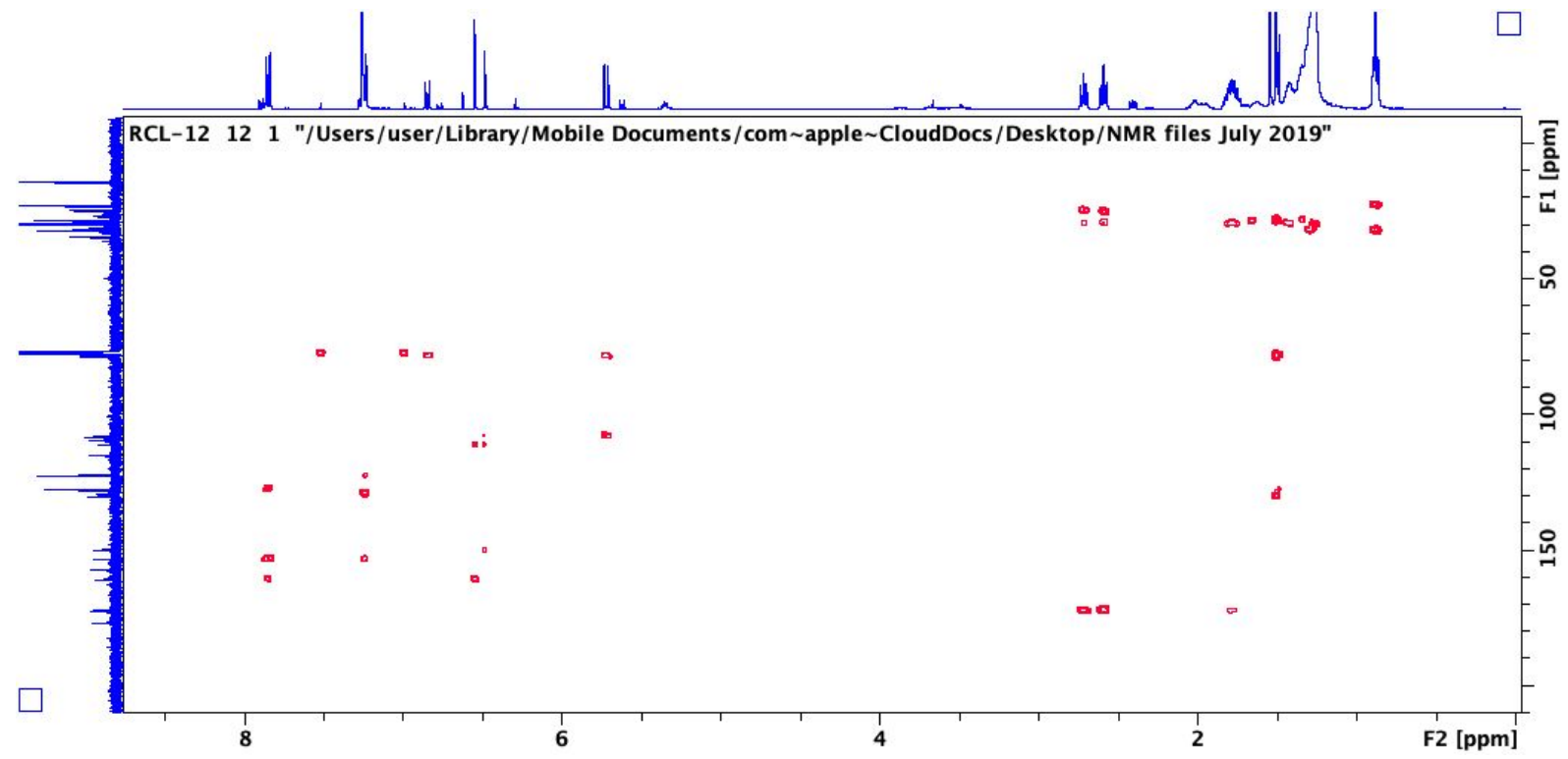

Figure S111: HMBC spectrum (400 MHz, CDCl3) for $16 a$

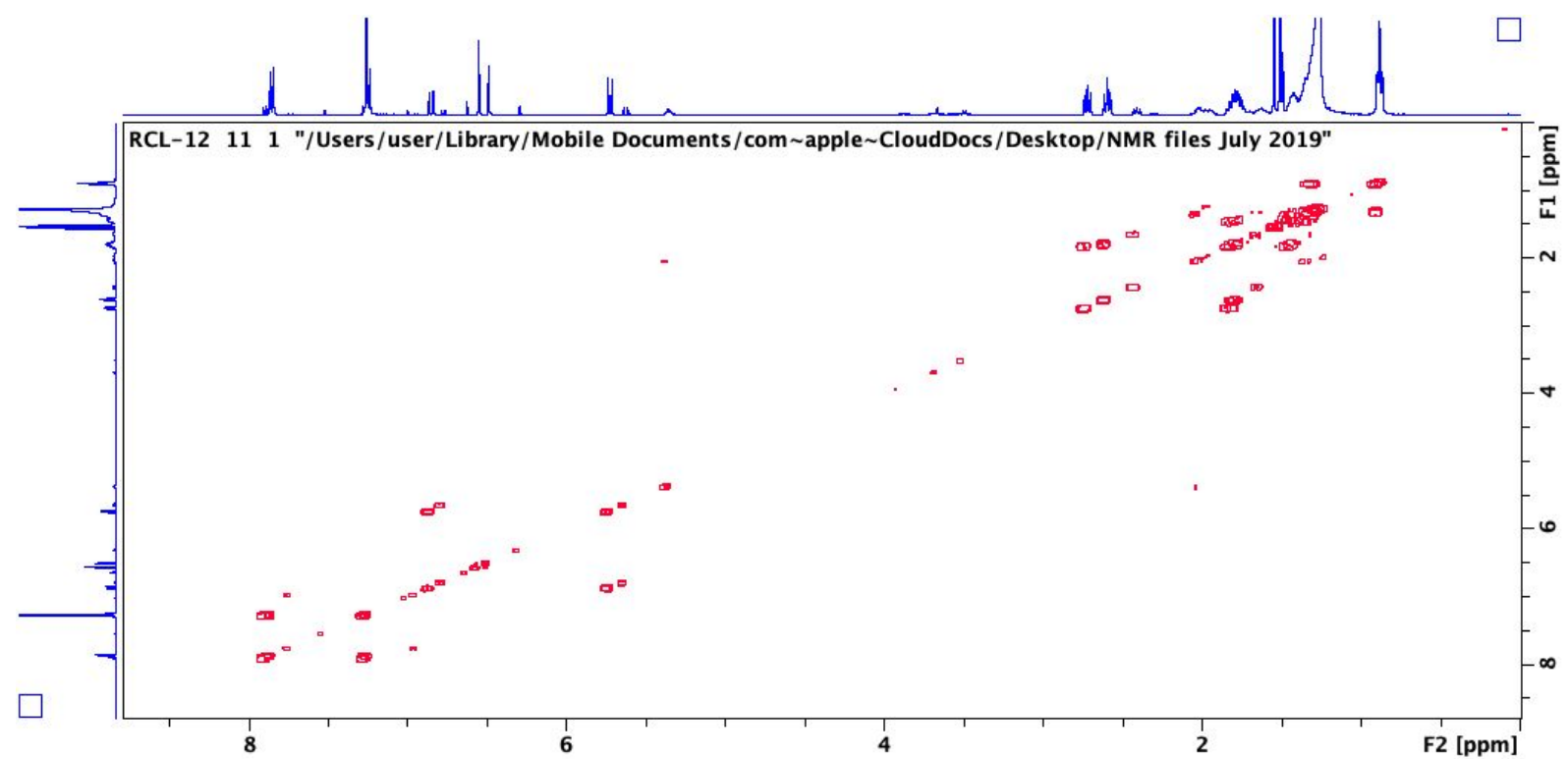

Figure S112: COSY spectrum (400 MHz, CDCl3) for 16 a 


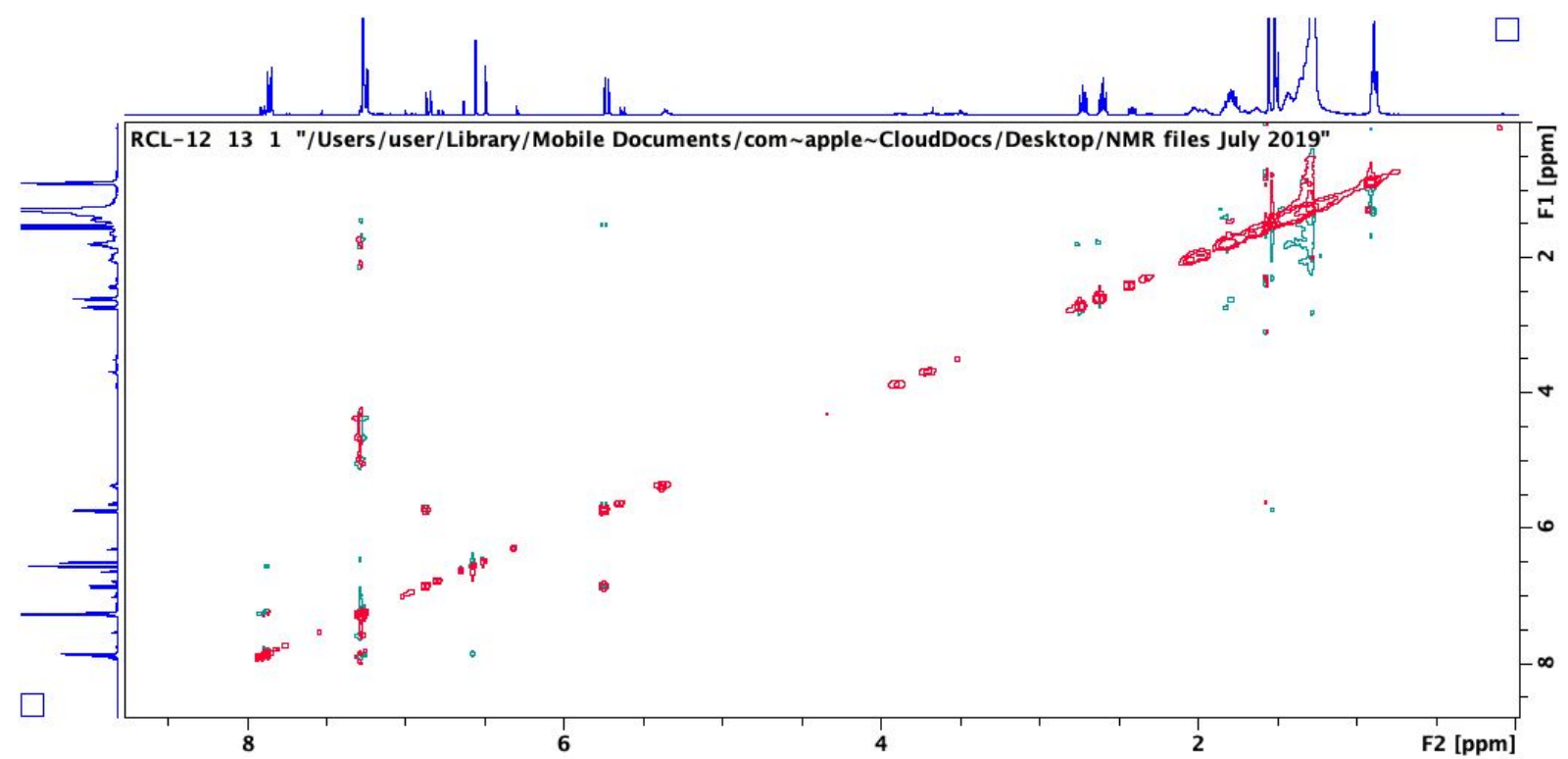

Figure S113: NOESY spectrum (400 MHz, CDCl3) for 16 a 


\begin{tabular}{|c|c|c|c|}
\hline \multirow{3}{*}{$\begin{array}{c}\text { Fractions/Polarity } \\
\text { A }(186.3 \mathrm{mg}) / \mathrm{Hex}- \\
\text { EtOAc }(9: 1, \mathrm{v} / \mathrm{v})\end{array}$} & \multicolumn{2}{|c|}{ Solvent systems } & \multirow{2}{*}{$\begin{array}{c}\text { Compounds obtained } \\
\text { Stigmasterol (22) (45.7 } \\
\mathrm{mg}) \text { and Sitosterol (23) } \\
(15.5 \mathrm{mg})\end{array}$} \\
\hline & $\begin{array}{l}\text { Added to silica gel } \\
\text { ( } 70-230 \text { mesh) and } \\
\text { subjected to gravity }\end{array}$ & $\begin{array}{l}\text { A solvent gradient starting } \\
\text { with Hex-EtOAc }(19: 1, \mathrm{v} / \mathrm{v})\end{array}$ & \\
\hline & $\begin{array}{l}\text { CC on a column } \\
\text { packed with silica } \\
\text { gel }\end{array}$ & $\begin{array}{l}\text { A solvent system of Hex- } \\
\operatorname{EtOAc}(9: 1, \mathrm{v} / \mathrm{v})\end{array}$ & $\begin{array}{c}\text { Clausarin (1) (50.0 mg) } \\
\text { and Suberosin (4) (55.0 } \\
\mathrm{mg})\end{array}$ \\
\hline $\begin{array}{l}\text { B }(87.8 \mathrm{mg}) / \mathrm{Hex}- \\
\operatorname{EtOAc}(7: 1, \mathrm{v} / \mathrm{v})\end{array}$ & & $\begin{array}{c}\text { Eluted with an isocratic } \\
\text { solvent system Hex-EtOAc } \\
(9: 1, \mathrm{v} / \mathrm{v})\end{array}$ & $\begin{array}{c}\text { Xanthyletin (2) (66.3 } \\
\text { mg) }\end{array}$ \\
\hline $\begin{array}{l}\text { C }(130.2 \mathrm{mg}) / \mathrm{Hex}- \\
\text { EtOAc }(17: 3, \mathrm{v} / \mathrm{v})\end{array}$ & & $\begin{array}{c}\text { Eluted with an isocratic } \\
\text { solvent system Hex-EtOAc } \\
(17: 3, \mathrm{v} / \mathrm{v})\end{array}$ & $\begin{array}{l}\text { 6-formylumbelliferone } \\
\text { (10) (35.6 mg). }\end{array}$ \\
\hline $\begin{array}{l}\text { D }(280.0 \mathrm{mg}) / \mathrm{Hex}- \\
\text { EtOAc }(33: 7, \mathrm{v} / \mathrm{v})\end{array}$ & & $\begin{array}{c}\text { Isocratic solvent system Hex- } \\
\text { EtOAc }(33: 7, \mathrm{v} / \mathrm{v})\end{array}$ & $\begin{array}{l}\text { Atalantaflavone (16) } \\
\quad(210.0 \mathrm{mg})\end{array}$ \\
\hline $\begin{array}{l}\mathbf{E}(66.0 \mathrm{mg}) / \mathrm{Hex}- \\
\operatorname{EtOAc}(31: 9, \mathrm{v} / \mathrm{v})\end{array}$ & & $\begin{array}{c}\text { Isocratic solvent system Hex- } \\
\operatorname{EtOAc}(4: 1, \mathrm{v} / \mathrm{v})\end{array}$ & $\begin{array}{c}E \text {-Suberenol (5) }(40.0 \\
\text { mg) and } E \text { - } \\
\text { methoxysuberenol (6) } \\
(8.0 \mathrm{mg}) .\end{array}$ \\
\hline \multirow[t]{2}{*}{$\begin{array}{c}\text { F }(100.4 \mathrm{mg}) / \mathrm{Hex}- \\
\operatorname{EtOAc}(7: 3, \mathrm{v} / \mathrm{v})\end{array}$} & & $\begin{array}{l}\text { A solvent system of Hex- } \\
\operatorname{EtOAc}(3: 1, v / v)\end{array}$ & $\begin{array}{l}\text { Thamnosmonin (7) } \\
\text { (54.3mg), hopey-hopin } \\
\text { (9) (20.7 mg) }\end{array}$ \\
\hline & & $\begin{array}{l}\text { A solvent system of Hex- } \\
\text { EtOAc }(13: 7, \mathrm{v} / \mathrm{v})\end{array}$ & 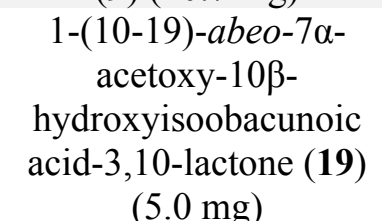 \\
\hline $\begin{array}{l}\text { G }(110.5 \mathrm{mg}) / \mathrm{Hex}- \\
\text { EtOAc }(3: 2, \mathrm{v} / \mathrm{v})\end{array}$ & & $\begin{array}{c}\text { Isocratic solvent system Hex- } \\
\text { EtOAc }(13: 7, \mathrm{v} / \mathrm{v})\end{array}$ & Limonin $(\mathbf{1 8})(85.5 \mathrm{mg})$ \\
\hline $\begin{array}{c}\text { H }(88.0 \mathrm{mg}) / \mathrm{Hex}- \\
\text { EtOAc }(1: 1, \mathrm{v} / \mathrm{v})\end{array}$ & & $\begin{array}{c}\text { Isocratic solvent system Hex- } \\
\operatorname{EtOAc}(1: 1, \mathrm{v} / \mathrm{v})\end{array}$ & Angelitriol (8) $(25.3 \mathrm{mg})$ \\
\hline $\begin{array}{c}\text { I }(103.0 \mathrm{mg}) / \mathrm{Hex}- \\
\text { EtOAc }(2: 3, \mathrm{v} / \mathrm{v})\end{array}$ & & $\begin{array}{c}\text { Isocratic solvent system Hex- } \\
\operatorname{EtOAc}(2: 3, \mathrm{v} / \mathrm{v})\end{array}$ & $\begin{array}{c}\text { Sitosterol-3-O- } \beta \text {-D- } \\
\text { glucoside (24) (85mg). }\end{array}$ \\
\hline
\end{tabular}




\begin{tabular}{|c|c|c|c|}
\hline \multirow{2}{*}{$\begin{array}{c}\text { Fractions/Polarity } \\
\mathbf{A}^{\prime}(38.0 \mathrm{mg}) / \mathrm{Hex}- \\
\text { EtOAc }(19: 1, \mathrm{v} / \mathrm{v})\end{array}$} & \multicolumn{2}{|c|}{ Solvent systems } & \multirow{2}{*}{$\begin{array}{l}\text { Compounds obtained } \\
\text { Lupeol (21) (21.0 mg) }\end{array}$} \\
\hline & $\begin{array}{l}\text { Added to silica gel } \\
(70-230 \text { mesh) and }\end{array}$ & $\begin{array}{l}\text { A solvent system of Hex- } \\
\text { EtOAc }(19: 1, \mathrm{v} / \mathrm{v})\end{array}$ & \\
\hline $\begin{array}{l}\mathbf{B}^{\prime}(35.0 \mathrm{mg}) / \mathrm{Hex}- \\
\operatorname{EtOAc}(37: 3, \mathrm{v} / \mathrm{v})\end{array}$ & $\begin{array}{l}\text { subjected to gravity } \\
\text { CC on a column } \\
\text { packed with silica }\end{array}$ & $\begin{array}{l}\text { An isocratic solvent system } \\
\text { Hex-EtOAc }(37: 3, \mathrm{v} / \mathrm{v})\end{array}$ & $\begin{array}{c}\text { Stigmasterol (22) }(15.0 \\
\mathrm{mg}) \text { and bergapten }(\mathbf{3}) \\
(8.0 \mathrm{mg})\end{array}$ \\
\hline \multirow[t]{2}{*}{$\begin{array}{c}\mathbf{C}^{\prime}(47.8 \mathrm{mg}) / \mathrm{Hex}- \\
\operatorname{EtOAc}(9: 1, \mathrm{v} / \mathrm{v})\end{array}$} & & $\begin{array}{l}\text { A solvent system of Hex- } \\
\text { EtOAc }(37: 3, \mathrm{v} / \mathrm{v})\end{array}$ & $\begin{array}{l}\text { 5-hydroxynoracronycine } \\
\text { (17) }(12.8 \mathrm{mg})\end{array}$ \\
\hline & & $\begin{array}{l}\text { A solvent system of Hex- } \\
\operatorname{EtOAc}(9: 1, \mathrm{v} / \mathrm{v})\end{array}$ & $\begin{array}{c}\text { 5-hydroxy- } 6,7,8,4^{\prime}- \\
\text { tetrametoxyflavone }(\mathbf{1 1}) \\
(15.3 \mathrm{mg})\end{array}$ \\
\hline $\begin{array}{c}\mathbf{D}^{\prime}(88.5 \mathrm{mg}) / \mathrm{Hex}- \\
\operatorname{EtOAc}(4: 1, \mathrm{v} / \mathrm{v})\end{array}$ & & $\begin{array}{l}\text { Isocratic solvent system Hex- } \\
\text { EtOAc }(17: 3, \mathrm{v} / \mathrm{v})\end{array}$ & $\begin{array}{c}\text { 5-hydroxy- } 6,7,8,3^{\prime}, 4^{\prime}- \\
\text { pentametoxyflavone } \\
(\mathbf{1 2})(50.0 \mathrm{mg}) \text { and } \\
\text { asperfenamate }(\mathbf{2 0}) \\
(10.4 \mathrm{mg})\end{array}$ \\
\hline $\begin{array}{l}\mathbf{E}^{\prime}(157.8 \mathrm{mg}) / \mathrm{Hex}- \\
\quad \operatorname{EtOAc}(3: 1, \mathrm{v} / \mathrm{v})\end{array}$ & & $\begin{array}{l}\text { With a solvent gradient } \\
\text { starting with Hex-EtOAc ( } 4: 1, \\
\text { v/v) and gradually increasing } \\
\text { the polarity using ethyl acetate }\end{array}$ & $\begin{array}{c}5,4^{\prime} \text {-dihydroxy- } 6,7,3^{\prime} \text { - } \\
\text { trimetoxyflavone }(\mathbf{1 3}) \\
(18.2 \mathrm{mg}), 5,4^{\prime}- \\
\text { dihydroxy-6,7,8,3'- } \\
\text { tetrametoxyflavone (14) } \\
\text { (27 mg) and } 5,6,7,8,4^{\prime}- \\
\text { pentametoxyflavone } \\
\text { (15) }(16.0 \mathrm{mg})\end{array}$ \\
\hline $\begin{array}{l}\mathbf{F}^{\prime}(63.8 \mathrm{mg}) / \mathrm{Hex}- \\
\operatorname{EtOAc}(1: 1, \mathrm{v} / \mathrm{v})\end{array}$ & & Crystalized and filtered & $\begin{array}{l}\text { Sitosterol-3-O- } \beta \text {-D- } \\
\text { glucoside (24) (23.4 } \\
\mathrm{mg}) \text {. }\end{array}$ \\
\hline
\end{tabular}

\section{Biological activities}

The minimum inhibitory concentration (MIC) of the extracts and isolated compounds were determined using broth microdilution method in 96-well microtitre plates. Briefly, two-fold serial dilutions of the extract and compound test samples were seeded in a 96 well microtiter plate and inoculated with bacterial inoculum at $10^{6} \mathrm{CFU} / \mathrm{ml}$ (McFarland) in a final volume of $100 \mu \mathrm{l}$ of Mueller Hinton broth medium (Oxoid, Thermo Scientific ${ }^{\mathrm{TM}}$ ). The final concentrations ranged from 500 to $0.244 \mu \mathrm{g} / \mathrm{ml}$ (for the plant extract) and 125 to $0.122 \mu \mathrm{g} / \mathrm{ml}$ for compounds and ciprofloxacin, the reference drug. The negative control made of broth medium and bacteria inoculum were treated with equivalent amount of DMSO at $0.5 \%$ (Loba chemie, India). The sterile control wells containing broth medium were included in the experiment. The plates were incubated at $37^{\circ} \mathrm{C}$ for $24 \mathrm{~h}$. The MICs were determined after addition of $20 \mu \mathrm{L}$ of the yellow rezasurin (alamarBlue ${ }^{\mathrm{TM}}$ Cell Viability Reagent) solution that 
viable bacteria reduce to a pink colour when incubated for $30 \mathrm{~min}$. The MIC was considered as the lowest concentration that gives no colour change, indicating no microorganism growth. The Minimal Bactericidal Concentration (MBC) was determined by sub culturing $50 \mu 1$ of culture media corresponding to wells without colour changes (without rezasurin) into $150 \mu \mathrm{L}$ of drug-free broth medium. After $24 \mathrm{~h}$ incubation at $37^{\circ} \mathrm{C}$ the $\mathrm{MBCs}$ were revealed by addition of rezasurin as above and defined as the lowest concentration with no colour change. Tests were performed in triplicates at three different times. The ratio MBC/MIC was calculated to determine the bactericidal $(\mathrm{MBC} / \mathrm{MIC} \leq 4)$ and bacteriostatic $(\mathrm{MBC} / \mathrm{MIC}>4)$ effects.

To characterise synergistic effects, three model organisms were used to characterise activity against Gram-positive (Bacillus subtilis BKK24010), Gram-negative (Escherichia coli BW25113) and fungal/eukaryotic (Saccharomyces cerevisiae strain BY4743) organisms. All organisms were maintained on agar until viable growth (two passages) before inoculation. Broth dilutions were undertaken according to the protocol described by the Clinical Laboratory Standards Institute (CLSI) using tryptone soya broth (B. subtilis \& E. coli) or SC broth (S. cerevisiae). All of the isolated compounds were individually combined with essential oil from the root, a commercially available leaf essential oil (petitgrain from Citrus aurantium, chemically similar to Citrus limon leaf essential oil) and E-caryophyllene. The $\Sigma$ FIC could not be calculated because no MIC value was observed for single compounds at the concentrations tested. 